Havas Ádám Kornél 


\section{Budapesti Corvinus Egyetem \\ Szociológia és Társadalompolitika Intézet \\ Szociológia Doktori Iskola}

Témavezető: Hadas Miklós, DSc

C Havas Ádám Kornél, 2018 


\author{
Budapesti Corvinus Egyetem \\ Szociológia és Társadalompolitika Intézet \\ Szociológia Doktori Iskola
}

\title{
Szegény rokonok: A magyar jazzszcéna szerkezete és rétegződése
}

\section{DOKTORI ÉRTEKEZÉS}

Témavezetô: Hadas Miklós, DSc

Havas Ádám Kornél

Budapest, 2018

(C) Havas Ádám Kornél 


\section{TARTALOMJEGYZÉK}

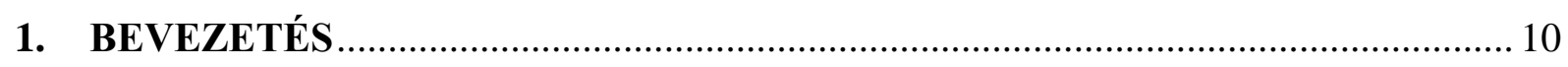

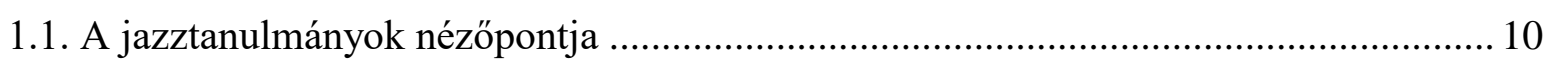

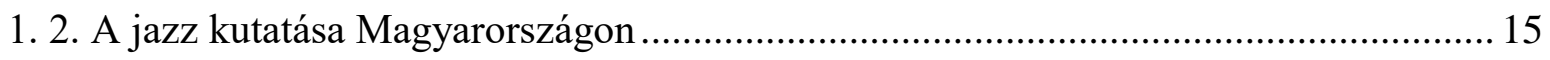

1.3. Szociológiai kérdésfelvetések a kortárs kutatások tükrében ................................... 18

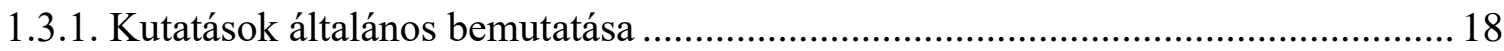

1.3.2. Jazz-zenészek mint kreatív munkavállalók ........................................................... 21

1.4. Kutatási kérdések bemutatása és a disszertáció felépítése .......................................... 22

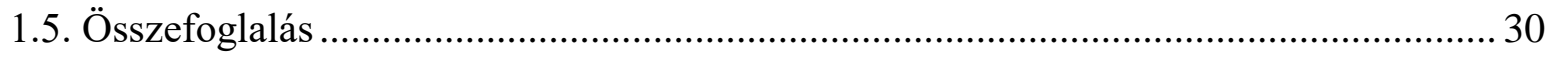

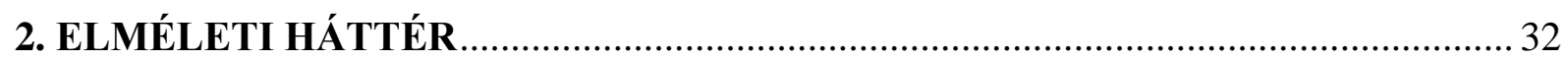

2.1. A magyar jazzszíntér konceptualizálása: versengő koncepciók ................................. 32

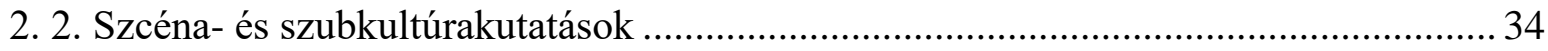

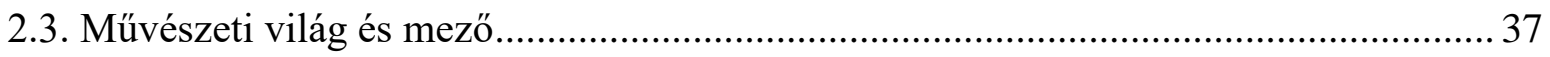

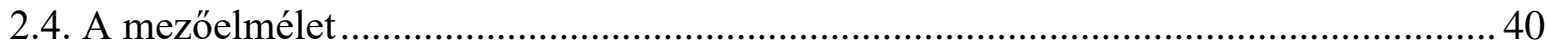

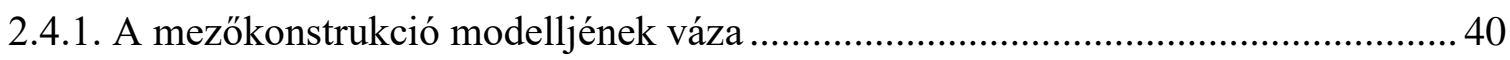

2.4.2. A korlátozott termelés és a tömegtermelés közti kapcsolatok ................................ 46

2.4.3. A mainstream és free jazz termelési módjai közötti relációk ................................. 49

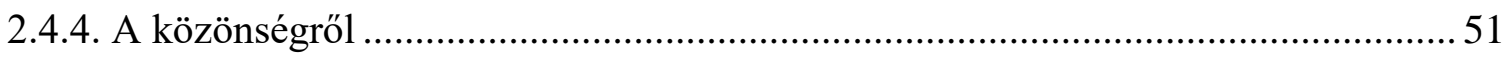

2.5. Jelentős harcok: A posztbourdieu-i zeneszociológiai megközelítésekről ................. 53

2.5.1. Művészetszociológia és a müvészetek szociológiája ..................................... 53

2.5.2. „Dolgok, amik összetartanak bennünket” - A hétköznapi élet és a zene

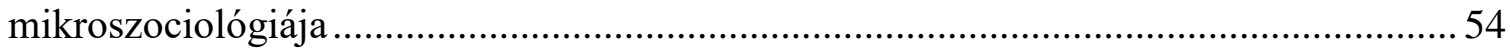

2.5.3. Homológia és mindenevők: a kultúraszociológiai erőtér polarizálódásának egy

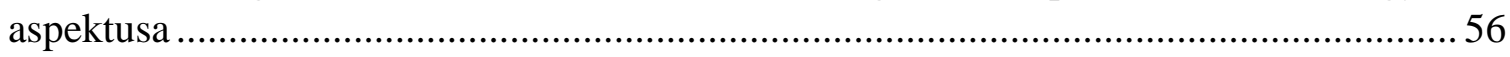

2.5.4. A heteronóm pólusok kultúraszociológiája és a „kvázi-felszentelt” gyakorlatok

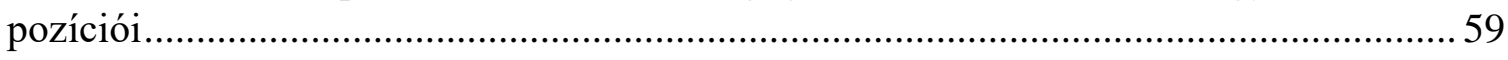

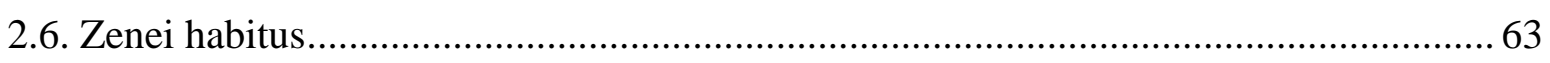

2.7. A kutatás relevanciája a kritizált Bourdieu-recepciók kontextusában.......................... 66

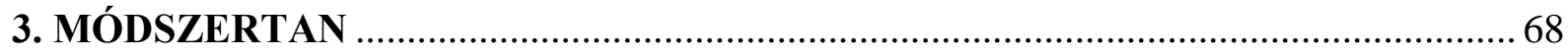

3. 1. Jazz-zenész? Tánczenész? „Hétköznapi” zenész? - a konceptualizálással kapcsolatos néhány dilemma. 


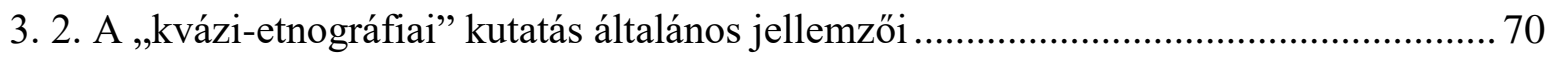

3. 3. A mezőelmélet alkalmazása a vizsgált összefüggések magyarázatában ..................... 73

3. 4. Önreflexiós kísérlet: az interjúkészítés és résztvevő megfigyelés körülményei és

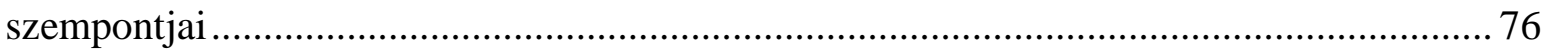

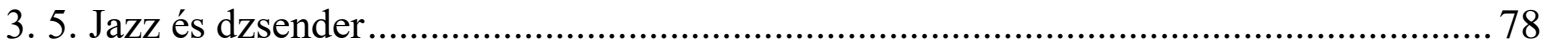

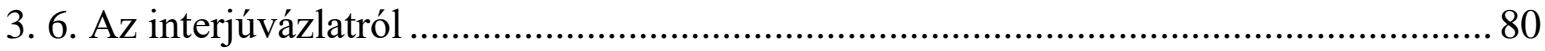

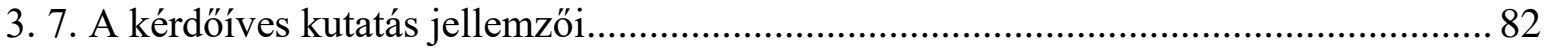

4. KÜLÖNBSÉGTÉTELEK RENDSZERE A MAINSTREAM - FREE JAZZ

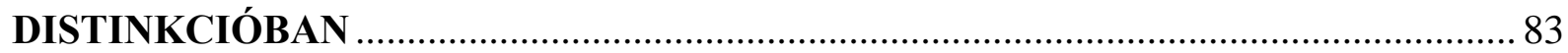

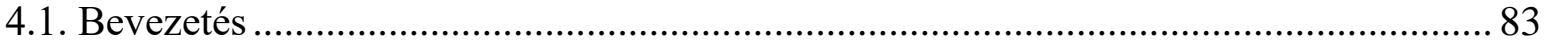

4. 2. Centrum - periféria viszonyok területi és szimbolikus dimenziói .............................. 85

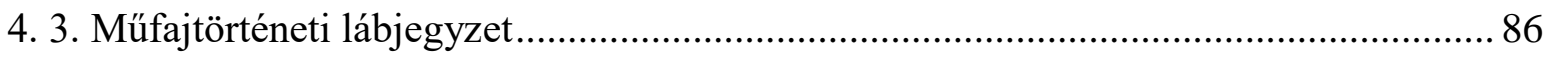

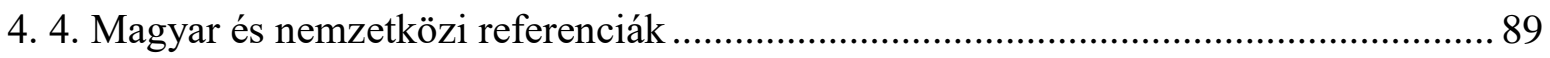

4. 5. Doxa és dogma: A tradícióhoz való viszony jelentéstartalmai.................................. 91

4. 6. A szimultán esztétikai hierarchia strukturális alapja ............................................ 97

4. 7. A free pólus differenciálódása és dogmatizmusa ..................................................... 100

4. 8. Legitimitásharcok: A szimultán esztétikák technikai dimenziója ............................ 104

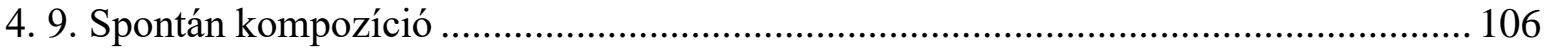

4. 10. Megélhetési stratégiák és a tevékenységtípusok hierarchiája.................................. 108

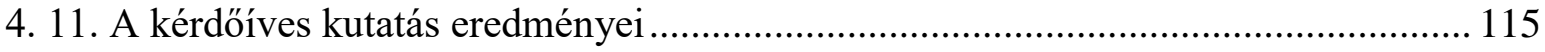

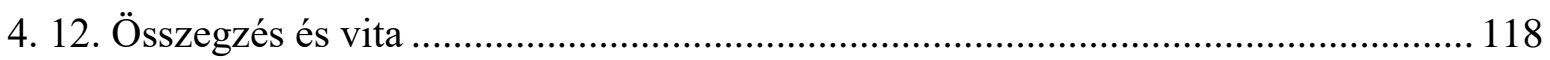

5. A KORTÁRS JAZZ ESZTÉTIKAI ÉS ETNIKAI KONSTRUKCIÓI: „CIGÁNY

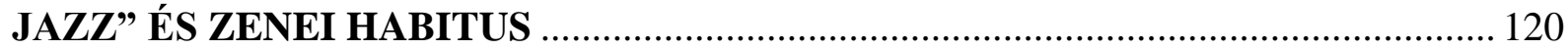

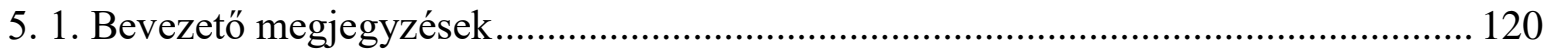

5. 2. A jazz-zenei mező felemelkedése és a muzsikuscigányok ....................................... 121

5. 2. 1. Zenészcigányok a legitimációs erőtérben, avagy hogyan kerülnek a kávéházból a

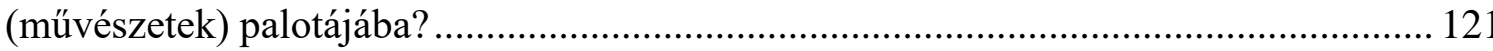

5. 3. Hangokba zárt folytonosság: A zenei szocializáció motívumai ................................ 124

5. 4. Az erös kötések ereje: rokonsági viszonyok a zenében .......................................... 132 
5. 5. A „cigány jazz” etnikai és esztétikai konstrukciói

5. 6. Összefoglalás

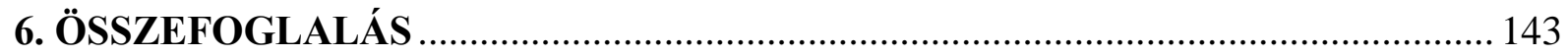

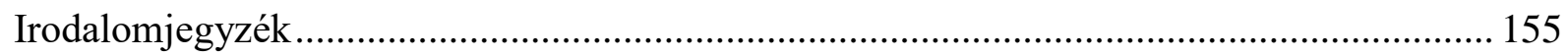

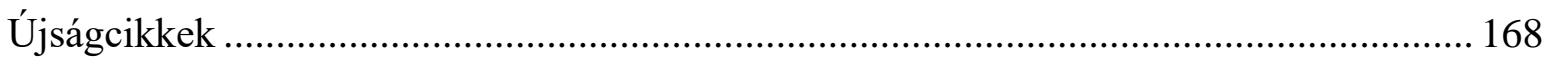

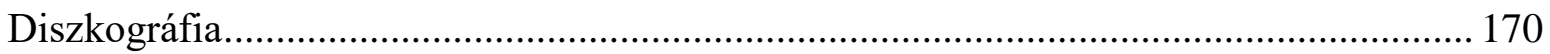

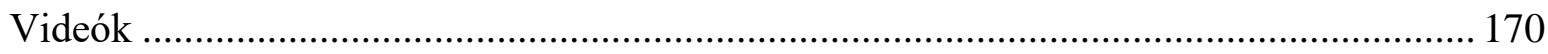

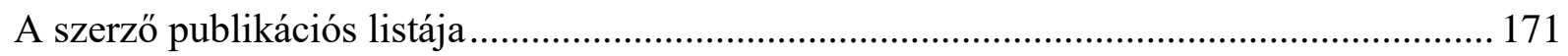

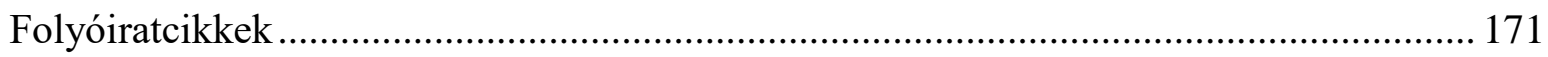

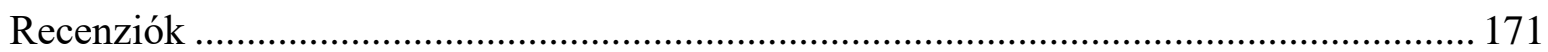

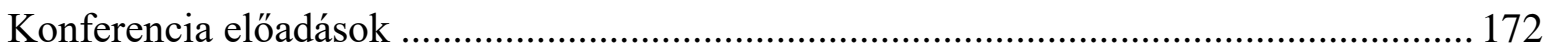

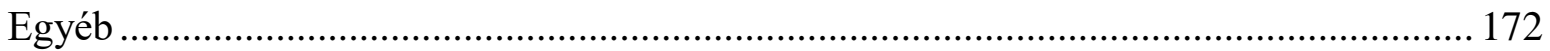

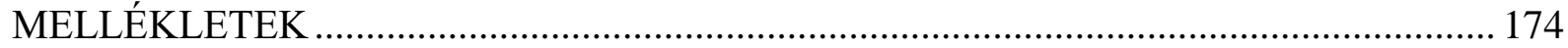

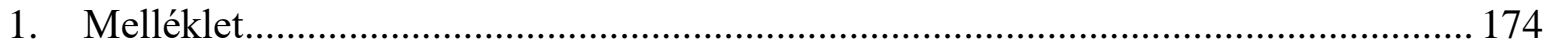

2. Melléklet: Fejes László (1965) „Esküvő”. Az 1965-ös Worldpress sajtófotó pályázat győztes képe. A kép nem lehetett az azonos címü '75-ös Szabados album borítója, a 2002-es kiadáson már a Fejes-kép szerepel (3. melléklet) ............................................................ 178

3. Melléklet: Szabados György „Esküvő” c. lemeze Fejes képével a borítón ................. 178

4. Melléklet: Egri János „Moods” c. lemezének belső borítója, mely jazz-zenész fiát, ifj. Egri Jánost és lányát ábrázolja. 


\section{TÁBLÁK ÉS ÁBRÁK JEGYZÉKE}

Táblázatok jegyzéke

- 1. táblázat: A budapesti jazz-színtér szerkezetét strukturáló oppozíciók

Ábrákjegyzéke

- 1. ábra: Zenei stratégiák legitimitáshierarchiája 


\section{KÖSZÖNETNYILVÁNÍTÁS}

Az értekezés alapjául szolgáló kutatás nem jöhetett volna létre a munkát és személyemet támogató barátok, jazz-zenészek és egyetemi oktatók bíztatása nélkül. A zenészek közül bőven a teljesség igénye nélkül hálás köszönet illeti Tóth Mátyást, Miskolczi Márkot, Ajtai Pétert és Oláh Krisztiánt, hogy megnyitották elöttem a „frontokat” és általuk olyan zenészekhez juthattam el, akikhez a közbenjárásuk nélkül csak nehezen sikerült volna. Köszönettel tartozom az interjúalanyoknak nyitottságukért és rugalmasságukért, sőt, a kutatás iránt való érdeklődésért is! Ser Ádámnak és Bozzay Csabának hálás vagyok a kutatás szakmai és anyagi támogatásáért.

Köszönöm a LFZE Jazz Tanszék vezetőjének, Binder Károlynak és Friedrich Károly tanár úrnak, hogy megnyitottak előttem a Jazz Tanszék kapuját, Párniczky Andrásnak pedig, hogy az ETÜD-ben fogadott szeretettel. A kutatással kapcsolatos konstruktív szakmai kritikákat az alábbi személyeknek köszönöm: Bruce Johnson, Zipernovszky Kornél, Arturo Rodríguez Morató, Paul Lopes és Simone Varriale. Wessely Annát és Barna Emíliát külön köszönet illeti, egyrészt a kritikák szóbeli kifejtéséért, másrészt azért, mert az opponensi bírálatokat a szükös rendelkezésre álló időn belül elkészítették. Fáber Ágostont és Berger Viktort is megkülönböztetett köszönet illeti a fordításokkal és szakmai kérdésekkel kapcsolatos „finishben” nyújtott segítségükért. Hálás vagyok Balogh „Elcsi’ Elemérnek a felém tanúsított türelméért, odafigyelésért és azért, hogy az ő sajátos szemszögéből, történetei révén hiteles forrásból nyerhettem betekintést a magyar jazz történetébe. Az értekezést az ő emlékének is ajánlom.

A részemről nem udvariassági formula csupán, hogy konzulensemnek, Hadas Miklósnak is köszönetet mondok: az ő állhatatos bíztatása, szakmai segítsége és atyai támogatása nélkül egészen biztosan nem készül el az értekezés a jelenlegi formában. Végül, a családomnak is szeretném megköszönni a kutatás során nyújtott töretlen támogatást.

Havas Ádám 2018. április 16. 


\section{BEVEZETÉS}

\subsection{A jazztanulmányok nézőpontja ${ }^{1}$}

Jelen doktori disszertáció célkitüzése az, hogy a 2014 ősze óta tartó kortárs magyar jazzszcéna rétegződését vizsgáló kutatás eredményeinek közlése által eredeti és innovatív módon járuljon hozzá a magyar és nemzetközi kultúraszociológia már meglévő korpuszához. ${ }^{2} \mathrm{Az}$ értekezés fejezetei a jellegzetesen modern társadalmi-kulturális gyakorlatként (Johnson, 2002b: 96-113) - tehát koránt sem kizárólag zenei praxisként értelemezett, a huszadik századi társadalmi változások és kulturális hierarchiák történeti dinamizmusa folytán sajátos emancipációs utat bejáró (Havadi, 2011, 2017; Jávorszky, 2014; Zipernovszky, 2017), tengeren túlról exportált müfaj szimbolikus különbségtételekkel összefüggő különböző aspektusait világítják meg.

A jazz studies vagy jazztanulmányok ${ }^{3}$ magyarországi kibontakozásával párhuzamosan e kutatás - Malecz $(1981,1987)$ munkáit leszámítva ${ }^{4}$ - az első, amely szociológiai modellalkotás igényével és módszereivel készül a kortárs jazz-zenészek mint kreatív munkavállalók (Umney és Krestos 2013, 2015) megélhetési stratégiáiról, valamint presztízsküzdelmeiről, és elsősorban a bourdieu-i mezőkonstrukció relacionális logikájával elemzi az erőtér belső hierarchiáját szervező tényezőket.

1 A disszertáció első, bevezető fejezete részben a már publikált saját (Havas, 2017a) és társszerzős (Zipernovszky és Havas, 2017; Havas és Ser, 2017) tanulmányaim átdolgozására épül.

${ }^{2}$ A 2014 őszén általam kezdeményezett kutatáshoz Ser Ádám, a Corvinus Egyetem szociológus doktorandusza csatlakozott 2016 tavaszáig. A magyar nyelven publikált társzerzős tanulmányom (Havas és Ser, 2017) megírásához Ser segítséget nyújtott az elméleti és kortárs szakirodalmak feldolgozásában, a kérdőíves adatok elemzésében és megírásában, ezenkívül a kérdőíves és kvalitatív kutatás anyagi támogatásában. Jelen értekezés alapját adó kvalitatív kutatást néhány transzkripció elkészítésétől eltekintve teljes egészében én végeztem.

${ }^{3}$ Ahogy a Zipernovszky Kornél és általam szerkesztett tematikus, „Jazztanulmányok” címen megjelent 101102-es Replika szám szerkesztői előszavában kifejtjük (Havas és Zipernovszky, 2017: 8), a jazztanulmányok kifejezést részesítjük előnyben a „new jazz studies”, vagy „új jazztanulmányok” helyett, mert a kulturális, vagy posztmodern fordulatot követően közkeletü „new jazz studies” is már régen beérett, csak úgy, mint az ,új muzikológia".

${ }^{4}$ Maróthy János nemzetközileg elismert zenetudós, a magyar (marxista) zeneszociológia és populáriszenekutatás pionírje 1968-69-ben szisztematikus jazz-kutatást kezdeményezett, ami azonban hamar elhalt (Barna és Tófalvy, 2017: 5). A rendszerezés alatt álló Maróthy-hagyaték publikálatlan anyagai az MTA Bölcsészettudományi Kutatóközpont Zenetudományi Intézet 20-21. Századi Magyar Zenei Archívumában találhatók. 
A kutatási kérdések, témafelvetések bemutatása előtt, a bevezető fejezetben a témaválasztás mellett sorakoztatok fel érveket: röviden arra kérdésre válaszolok, miért legitim szociológusként Magyarországon jazzt kutatni, melyhez egyrészt a jazz studies-ként, vagy new jazz studies-ként elterjedt diszciplína nézőpontja(i) felől közelítek, majd a jazztanulmányok néhány szociológiai relevanciáját tisztázom nemzetközi és magyar viszonylatban. A referenciaértékkel bíró kutatások bemutatásánál föként azokra a szempontokra koncentrálok, melyek a kortárs magyar jazzszcéna kutatásánál is hangsúlyosak voltak. Ilyen szempontok a jazz kulturális legitimitások hierarchiájában elfoglalt pozíciójával, a müfajon belüli szimbolikus különbségtételek logikáját meghatározó társadalmi tényezőkel, vagy a különböző habitusú, eltérő esztétikai nézeteket valló jazzzenészek megélhetési stratégiáival függnek össze. Mivel a kutatott téma konstrukcióját, így a felvetett kutatási kérdéseket is alapvetően meghatározza az a jazztanulmányokban széles körben elfogadott álláspont, mely szerint a jazz nem csupán esztétikai és muzikológiai koncepciókkal leírható zenei müfaj, hanem a modernitás stílusjegyeit sajátosan magán viselő kulturális gyakorlat, először érdemes a műfaj zenén túlmutató társadalmi-kulturális jelentéseiből kiindulni.

Ahogy Gabbard is rámutat (2002: 2) a ,jazz" szó első írásos említései San Franciscói újságok sportrovatainak hasábjain az 1910-es években még egyáltalán nem kapcsolják a jazzt valamilyen sajátos stiláris jellegzetességekkel bíró zenei irányzathoz. Noha az 1920-as évek irodalmi forrásai alapján a jazzt erőteljes szexuális asszociációkkal (Zipernovszky, 2017), illetve sokszor magával a szexuális aktussal azonosították, ${ }^{5}$ az Egyesült Államok szóbeli kultúrájában már a századforduló környékén jelen volt a jazz, mint elsősorban „energiát”, „életeröt”, „lendületet”, „élvezetet” jelentő kifejezés. Ahogy a rock and roll szexuális, „deviáns” konnotációi is lassan „kikoptak”, a „dübörgő húszas évek” (Roaring Twenties) jazzkorszakát és a müfaj '40-es évek közepén bekövetkezett modernista fordulatát követően fokozatosan a jazz is megszabadult a dekadens asszociációktól ${ }^{6}$, és elsősorban már zenei gyakorlatot jelölt (Johnson, 2002b). Ez az emancipációs törekvés történeti perspektívából kifejezetten a '40-es évek közepétől, a müfajban bekövetkezett modernista fordulatot követően érhető tetten (Lopes, 2002), mikor a kulturális legitimitásért küzdő jazz, piaci kényszerektől relatíve független magaskulturális gyakorlatként igyekezett pozícionálni magát (Deveaux, 2017 [1991]), szemben a kommerciális, szórakoztató tánczenével, melyhez

\footnotetext{
${ }^{5}$ Lásd pl. a saxophone-sexophone (Zipernovszky, 2017: 69, 72) és jazz-jism szójátékokat (Johnson, 2002a: 34).

${ }^{6}$ Az 1917-ben készült első jazz felvételt széles körben az Original Dixiland Jazz Bandnek tulajdonítják.
} 
sokszor a deviancia és dekadencia konnotációi társultak. ${ }^{7}$ A jazztudósok és jazztörténészek pedig, föleg stílusokhoz (dixieland, szving, [be]bop, hard bop, cool jazz, jazz-rock, fúzió stb.) és nagy egyéniségek munkásságához kapcsolódó lineáris történeti narratíva kiépítésének - és nem utolsósorban - elsajátításának az igényével (Gabbard, 1995; Johnson, 2002b; DeVeaux, 1997, 2017 [1991]; Lopes, 2002) ${ }^{8}$ nekiláttak a jazztörténet retrospektív konstruálásának, illetve kanonizálásának.

Bruce Johnson (2002a) kultúra-és jazztudós The Jazz Diaspora [A jazz diaszpóra] címü tanulmányában a (1) formális, „textusközpontú” és az alapvetően társadalmi kontextusokat hangsúlyozó (2) kulturális megközelítések eltéréseit a jazz által reprezentált különféle kulturális gyakorlatok sokszínüségével magyarázza (Johnson, 2002a: 34). Eme kulturális kontextusokat hangsúlyozó, jellegzetesen interdiszciplináris nézőpont a műfaj társadalmi jelentéseit - és jelentőségét - hangsúlyozza olyannyira, hogy Johnson az ausztrál modernitás két világháború közti narratíváját a jazz fejlődésének társadalmi, kulturális, technológiai, gazdasági és politikai kontextusaiban igyekszik bemutatni (Johnson, 2000; Havas, 2017b). A jazztörténet és a jazztanulmányok közti fö különbség abban rejlik, hogy míg a mainstream jazztörténeti kutatások egy megkülönböztetett, autonóm jazztradíció megalkotásában és fenntartásában érdekeltek (Lopes, 2002: 3), addig a jazztanulmányok (jazz studies) a jazz-szel összefüggő intézményes, kultúrpolitikai és társadalmi gyakorlatokra fókuszálnak. A módszereit és episztemológiai pozícióját tekintve interdiszciplináris, a perspektívája pedig szélesebb, mint a sokat kritizált (Pl. DeVeaux, 2017 [1991]) történeti megközelítések diakrón nézőpontja.

A jazz kutatásában mérföldkőnek számító amerikai intézmény, az Institute of Jazz Studies 1952-es létrehozása óta különböző diszciplínák - elsősorban a történettudomány, később a (kultúra)szociológia - tudományos rangra emelték ugyan a müfaj szociokulturális kontextusainak elemzését, mégis a kutatási terület bölcsőjének számító Egyesült Államokban is sokáig akadémiai undergroundnak (Buckner és Weiland, 2001) számított a jazz-szel kapcsolatos tudományos praxis. A jazz kutatása szakmai marginalizálódás

\footnotetext{
${ }^{7}$ Lásd pl. Becker Outsiders [Kívülállók] c. meghatározó művének tánczenészekről szóló fejezetét (Becker, 1966: 79-95), melyben a szerző mint „deviáns csoportot” tematizálja a jazzt is játszó tánczenészeket.

${ }^{8}$ Erről a lineáris történeti narratíváról írja Lopes (2002: 8), hogy a ,jazztörténetek a népmüvészettől a populáris, majd a magas müvészetig ivelö zenei fejlődést mutatnak be.” A fordítás az eredetiből (Lopes, 2004: 8) a sajátom: H.Á.
} 
veszélyével fenyegetett, melyet olyan jazzszerető tudósok ${ }^{9}$ kockáztattak szenvedélyükért, akik más-más szemszögből elemezték a müfaj zenén túli (szociális, etnikai, kulturális stb.) relevanciáit (Peretti, 1993). Csakúgy, mint Amerika különböző régióiban, a műfaj európai integrációja során is a helyi szociokulturális kontextusok sokszínüségének megfelelően eltérő mintázatokat öltött, és töltött be esztétikai, kulturális vagy politikai funkciókat az adott országban: ${ }^{10}$

A jazzt nem találták fel, azután nem exportálták. Abban a folyamatban jött létre, ahogy elterjedt. Úgy is mint gondolat és mint gyakorlat, a jazz az elterjedésének hordozóeszközeivel és az adott helyen talált feltételekkel való egyezkedés során jött létre. A diaszpórikus újralétrejövések komplexitása nem egyszerúen annak következménye, hogy a jazz éppen melyik verzióját exportálták. Azok a feltételek, amelyekkel ezek az exportálások szembesültek, újraszervezték a müfajt és jelentéseit (Johnson 2002a: 39). ${ }^{11}$

Mára elméleti és módszertani orientációját tekintve is meglehetősen eltérő (al)diszciplínák tárgyaként (a kritikai zenetudományon át az etnikai kontextust hangsúlyozó black american studies-on keresztül a munkaszociológiáig és a kultúraszociológia fősodrába sorolható kutatásokig) különböző esztétikai, etnikai szociális és gazdasági szempontokat hangsúlyozva a jazz kutatása legitim tudományos tevékenységnek számít, nem csupán az angolszász tudományos életben. ${ }^{12} \mathrm{~A}$ jazz mint társadalmi-kulturális jelenség diszciplínákat átölelő szemléletét jól illusztrálja például az is, hogy a műfajról - konkrétabban a jam sessionök világáról - született egyik legnépszerübb kortárs szociológiai monográfiáról (Becker és Faulkner, 2009), a fogyasztói magatartás és marketing tekintélyes kutatója, Holbrook (2010) (is) recenziót írt. A növekvő interdiszciplináris érdeklődés (Davis, 2012) részben annak tudható be, hogy a jazz történeti fejlődése során megszünt kizárólag az

\footnotetext{
${ }^{9}$ A jazzről író társadalomtudósok sok esetben a müfajt maguk is amatőr, profi vagy félprofi szinten művelő muzsikusok is, pl. a kultúraszociológia klasszikus tekintélyeinek számító Howard S. Becker és Robert R. Faulkner, továbbá Alfonso Montuori, George McKay, Paul Lopes, Krin Gabbard, vagy a fiatalabb generációt képviselő Mark Doffman brit kultúrakutató, jazzdobos.

${ }^{10}$ A jazz európai aspektusairól lásd pl. Simon (1990, 1999); Braggs (2016); Budds (2002); Von Eschen (2004); McKay (2005); Havadi (2011); Toynbee et al. (2014); Jávorszky (2014); Zipernovszky (2014, 2015).

${ }^{11}$ A Johnson-idézet Zipernovszky Kornél fordítása (lásd Zipernovszky és Havas, 2017: 9).

${ }^{12}$ A jazzszakirodalom széles palettájáról tanúskodik a Davis (2012) által összeállított és szelektált bibliográfia, illetve különböző ,jazz diaszpóra” kutatások (Braggs, 2016), melyek a jazz lokális beágyazottságának nemzeti sajátosságokkal és etnikummal összefüggő kérdéseit kutatják.
} 
amerikai feketék zenéjének lenni, ${ }^{13}$ másrészt a kutatás egyik témáját is adó, a jazz fejlődésével kapcsolatos progresszív/avantgárd és neoklasszicista/purista ${ }^{14}$ értelmezések ellentmondásaiból fakadóan (DeVeaux 2017 [1991]; Nicholson, 2005).

Ahogy DeVeaux (2017 [1991]) a konvencionális jazztörténet lineáris, esszencialista narratívájának kritizálása során rámutat, ${ }^{15}$ a müfaj empirikusan megalapozott történetének megalkotásához a sokszor egymással szembenálló multietnikus és multistiláris perspektíváit is figyelembe kell venni, nem elegendő a müfaj történetében jelenlévő kaotikus stíluskavalkádot leegyszerüsítve a jazzfogalom „ernyője” alatt értelmezni. Finkelstein (1948) már a ’40-es évek közepén - tehát a bebop stílus születésének és kezdeti virágzásának időszakában - három fö ,vitás” területet jelölt meg a jazz-szel kapcsolatban: az (1) eredetére vonatkozó diskurzusokat, a (2) a jazz többi művészethez való viszonyát, valamint a (3) a kommersz és „tiszta jazz-zene” dichotómiáját. Európában a fenti főbb kérdéseken túl, melyekkel már a '60-as évektől magyar szerzők is foglalkoztak (Gonda 1965; Pernye 1964), a különböző politikai rendszerek ideológiáival és kultúrpolitikájával kapcsolatos összefüggések sajátos kérdéseket vetettek fel. Fontos különbség azonban, hogy míg DeVeaux-nak a jazzhagyomány konstruálásáról írt mérföldkőnek számító tanulmánya utáni diskurzusok az Államokban termékenyen hatottak a jazz különböző aspektusainak interdiszciplináris elemzéseire, Magyarországon a 2010-es évek második felében kibontakozó törekvésekig ${ }^{16}$ gyakorlatilag nem létezett árnyalt társadalomtudományi diskurzus a műfaj fejlődéséről - néhány jazzkedvelő szerző (Pernye 1964; Simon 1999;

\footnotetext{
${ }^{13}$ A jazz történeti narratíváját diakrón módon konstruáló hagiografikus történeti szemlélettel szemben a jazz diaszpórák kutatása szakít az Amerika-központú elbeszélésekkel és a müfajt a sajátos lokális kontextusokban vizsgálja (Zipernovszky és Havas, 2017: 9).

14 A jazztanulmányokban megkerülhetetlen DeVeaux-tanulmány a következő definícióját adja a neoklasszicista alapállásnak „(..) akik ragaszkodnak a hagyomány elsődlegességéhez, és inspirációjukat, identitásukat a történelmi múlthoz kötödö összekapcsoltság érzéséből merítik, ami szembeállítja öket mind az avantgárd folyamatos forradalmával, mind a fúziós zene kommersz orientációjával" (DeVeaux, 2017 [1991]:
} 15).

15 Dolgozatában azzal a fősodorba tartozó történeti elképzeléssel kapcsolatban tesz kritikai megállapításokat, mely a - közhelyesen Amerika klasszikus zenéjének elkönyvelt - jazz történetét az egymás után következő főbb korszakok stiláris jellegzetességeinek leírásával, valamint a hozzájuk kapcsolódó kanonizált alkotók és müveik méltatásával alkotják meg.

${ }^{16}$ A jazztanulmányok kortárs magyar törekvéseiről és előzményeiről részletesebben lásd (Zipernovszky és Havas 2017: 7-12; Zipernovszky, 2017). 
Gonda 2004) - akadémikus elmélyültséget többnyire nélkülöző zenetörténeti munkáin kívül, melyek azonban kívül esnek a DeVeaux által szorgalmazott önreflexív kutatói paradigmán.

\subsection{A jazz kutatása Magyarországon}

A századforduló Amerikájának multikulturális nagyvárosaiban születő stílus Magyarországon már az 1920-as években, egyes szerzők szerint már a Monarchia idején jelen volt (Simon, 1999), ${ }^{17}$ mégis, magyarországi elterjedését a változó társadalmi-politikai erőtér komplexitásának szemszögéből meglehetősen kevés tudományos igényü munka dolgozta fel. A hazai folyamatokról számon tartott néhány mű közt találjuk a „Jazztanszak”18 alapítója, Gonda János szintetizáló munkáját (2004), a szakmai vitákat kiváltó „,vitatott magyar jazztörténetként"19 is aposztrofált Simon-féle monográfiát (1999), mely a '60-as évekig követi eklektikus módon a müfajjal kapcsolatos honi eseményeket, továbbá Turi interjúkötetét (1983), melyben az államszocializmus jazzéletének meghatározó alakjai nyilatkoznak jazz-szel kapcsolatos kérdésekről. A legújabb történeti monográfiát jegyző Jávorszky (2014) által kínált narratíva átfogóan tárgyalja a magyar jazz történeti fejlődését, valamint a meghatározó muzsikusokhoz és formációkhoz köthető különböző irányvonalakat. Jóllehet művét egyfajta hibridként említik, utalva annak szakkönyv jellegére és a szélesebb közönségnek szóló kevésbé tudományos nyelvezetére, A magyar jazz története a rendszerváltás utáni müfaji és intézményes fejlődésről is átfogó képet nyújt. Az 1969-ben alapított Zenetörténeti Intézet Zeneszociológiai Osztályán Maróthy János által kezdeményezett rövid életü jazzkutatástól eltekintve (Barna és Tófalvy, 2017: 5) szigorúan vett társadalomtudományos munka Malecz nevéhez $(1981,1987)$ füződik, aki szociológiai módszerekkel vizsgálta a jazzkoncertekre járás indítékait, a közönség ízlését és demográfiai

\footnotetext{
${ }^{17}$ Simon írásai e tekintetben elnagyoltak ugyan, annyi bizonyos, hogy a jazz fejlődése szempontjából fontos tánczenék - mint a cakewalk és a ragtime - elértek az Osztrák-Magyar Monarchiába.

${ }^{18}$ Az 1972-től 1989-ig fennálló Magyar Zenemüvészek Szövetségének Jazz Szakosztálya fontos állomása volt a jazz honi intézményesülésének, melynek első elnöke, Gonda János, a szocialista blokk országai közül Magyarországon alapította meg az első jazz tanszéket 1965-ben, beemelve a müfajt a hivatalos oktatás keretei közé. A tanszék ma a Liszt Ferenc Zeneművészeti Egyetem Jazz Tanszéke, melyet a hallgatói szlengnek megfelelően ,jazztanszaknak”, „tanszaknak” is hívok. Érdekesség, hogy Seiber Mátyás volt a világ első (!) felsőfokú akadémiai jazzprogramjának vezetője 1928-ban a Hoch Konzervatóriumban.

${ }^{19}$ A jelzőt Jávorszky Simon könyvéről írt recenziójának (1999) címéből vettem át.
} 
összetételét a '80-as években, noha módszertanát és következtetéseinek hitelességét a kutatók fenntartásokkal kezelik. ${ }^{20}$

A magyar jazz második világháború utáni történetét a (történeti) szociológia eszköztárával Havadi (2011) dolgozta fel folyamatban lévő kutatása során, „A magyar jazz politikai és társadalmi konstellációja az ötvenes és a hatvanas években” beszédes alcímet viselö, a '80-as évekre is kitekintő tanulmányában. A jazz politikai-társadalmi „konstellációját” és emancipációját vizsgáló munkájában felvázolt narratíva elemei alkalmasak a jazz rendszerváltás előtti társadalmi-kulturális szerepének viszonylagos tisztázására. Kutatási kérdéseim bevezető történeti kontextualizációjának céljából főleg azok a szempontok kerülnek röviden bemutatásra Havadi történeti-szociológiai szemléletü dolgozatára is támaszkodva, amelyek valamilyen módon kapcsolhatók a kortárs jazzélet rétegződéséhez, és árnyalják az értekezés empirikus fejezeteiben elemzett mainstream-free jazz különbségtétel történeti kialakulását.

Havadi amellett érvel, hogy Magyarországon a pártállami diktatúra tudatos, szabályozó módon reagált a jazzre, mely a keleti blokk országaiban egyfajta kulturális trójai falóként (Jávorszky, 2014) ${ }^{21}$ funkcionált a hidegháború idején - jóllehet a kultúrpolitikai irányítás a müfajt a burzsoá tánczene és szórakozás egy dekadens irányzatának, és nem teljes értékű müfajnak tekintette (Gonda, 2004). A „,Szving aranykorának” is hívott koalíciós időszak után az '50-es években a jazzt, a „kozmopolita”, „dekadens” és „,imperialista” ideológiailag konstruált jelzőivel illető (Havadi, 2011: 140) kultúrpolitika határozottan tiltotta. A vendéglátás közösségi tereiben létező műfajt a vendéglátóhelyek államosítása szinte megfojtotta, noha a müvészek és játszóhelyek egy része sajátos technikákkal ideigóráig ki tudta játszani a szigorú szabályozást. Enyhülés csak a '60-as években volt érzékelhető, ${ }^{22}$ viszont ha a műfaj emancipációja szempontjából olyan fontos eseményeket veszünk alapul, mint a nagy presztízsủ állami díjak odaítélését (Kossuth-, Erkel- és Liszt-

\footnotetext{
${ }^{20}$ Lásd Havadi Gergő (2017) Kádár-korszak jazzklub-hálózatáról írt friss tanulmányát, különösen (2017: 130, 137-139).

${ }^{21}$ A jazznagykövetek és a jazzprogramokat is sugárzó rádióállomások szerepéről lásd még Havadi (2011) és Von Eschen (2004) munkáit.

22 A Dália presszó Ifjúsági Jazz Klubja is ebben az időszakban alakult (1962-1966), továbbá a Magyar Hanglemezgyártó Vállalat 1962-ben kezdte el a Modern Jazz lemezantológiai sorozatának kiadását, és az első magyar jazzfesztivált is a '60-as években, 1965-ben rendezték. A magyar jazz '60-as évekbeli korszakáról bővebben lásd pl. Szeverényi (1980) és Retkes (2012) munkáit.
} 
díjak stb.), rádiószereplést vagy akár közösségi terek(b)en való megjelenést, egyértelmü a müfaj periferikus helyzete.

További kutatások szükségesek annak megválaszolására, hogy a jazz miért nem vált valódi tömegeket megmozgató kulturális entitássá Magyarországon néhány világsztár, pl. Louis Armstrong (1965), Count Basie (1970) vagy Duke Ellington (1971) tömegérdeklődést kiváltó fővárosi koncertjeit leszámítva. Annyi azonban biztos, hogy a jazz legitimációjának növekedésével ${ }^{23}$ fokozatosan eltávolodott a tömegkultúrától, és a komolyabb művészet presztízsére törekedett, miközben föképp a fiatalok körében nem tett szert tömegbázisra még a rendszerváltás éveiben sem. Ez utóbbi oka talán az volt, hogy az ellenkultúra kulturális orgánumai pont az egyre népszerübb, alapvetően vokális rock- és punkzene voltak (Barna és Tófalvy, 2017; Szemere, 2001). Az egyik közkeletü hipotézis szerint, mire a politikai nyomás végre enyhült, a beat- és rockkorszak szöveges zenei irányzatai kihúzták a műfaj lába alól a talajt, mely azután egyfajta légüres térben találta magát a kulturális erőtérben, ahonnan egyre határozottabban a magaskultúra státusza felé pozícionálta magát. Gonda János „alapítóatya” hagyományát követi az LFZE Jazz Tanszékének jelenlegi vezetője, Binder Károly is, ami megjelenik az egyik általa adott interjúban (2001), melyben fó ambíciójának tekinti, hogy a műfaj a komponált zenékkel egyenrangú státuszra tegyen szert, ami - ha nem is bizonyítja, de - kellően illusztrálja a jazz populáris müfajoktól való távolságtartásának szándékát. Kutatásom jazz státuszára, kulturális erőtérben való legitimációjára vonatkozó kérdései nemcsak a szcénán belüli pozíciók dinamizmusát világítják meg, de empirikus alapon is árnyalják a kortárs jazz státuszával kapcsolatos legfontosabb kérdéseket.

A jazztanulmányok honi kibontakozása és emancipációja szempontjából a Szegedi Tudományegyetem Amerikanisztika Tanszéke által kiadott Americana folyóirat jazztanulmányi száma, ${ }^{24}$ valamint újabban a 101-102-es tematikus Replika szám megjelenése fontos mérföldkőnek számít. A tudományterület interdiszciplináris szemléletéhez hüen e kötet a dzsendertanulmányok, ${ }^{25}$ szociológia, történet-és

\footnotetext{
${ }^{23}$ A jazz emancipációjáról például olyan események tanúskodnak, mint a Jazztanszak alapítása, szaklapok, később weboldalak megjelenése, díjak, fesztiválok és érdekvédelmi szervezet létrehozása, valamint a '80-as évek közepétől számított viszonylagos politikai enyhülés.

24 Bővebben a számról: E-Journal of American Studies in Hungary Special Issue On Jazz. Interneten: http://americanaejournal.hu/vol10jazz.

${ }^{25}$ A magyar tudományos életben a „dzsender” bevett, kanonikus szóhasználatnak számít, a társadalmi nemeknek fordított gender szinonimájaként használják (lásd pl. Hadas, 2011).
} 
kultúratudomány nézőpontjait képviselő kutatók - Federmayer Éva, Bognár Bulcsu, Dolinszky Miklós, Havadi Gergő, Molnár Dániel, Zipernovszky Kornél, valamint Ser Ádám és jelen doktori dolgozat szerzőjének - munkáit publikálta. ${ }^{26} \mathrm{Ha}$ azonban a magyar populáriszene-kutatás populáris műfajokat, így részben a jazzt is átfogó szélesebb horizontja felől közelítünk a jazztanulmányok emancipációjához, a Barna és Tófalvy (2017) által szerkesztett Made in Hungary címen megjelent kötet is fontos mérföldkőnek tekinthető, melyben, egy a kortárs magyar jazzről szóló kvalitatív kutatás is helyet kap (Szabó, 2017: 37-47; Havas, 2018a).

\subsection{Szociológiai kérdésfelvetések a kortárs kutatások tükrében}

\subsubsection{Kutatások általános bemutatása}

Az erőteljesen fővárosban koncentrált kulturális erőtér vizsgálata során fontosnak tartottam a kutatást nemzetközi, elsősorban kortárs szociológiai kutatások dimenziójában is pozicionálni, nem is elsősorban az összehasonlíthatóság miatt (melyre forráshiány, koncepcionális eltérések és a komparatív elemzés módszertani buktatói miatt nem volt lehetőség), hanem a kutatások elméleti-módszertani megközelítéseinek átfogóbb ismerete végett. A feldolgozott kutatások a szociológiai módszertan széles arzenálját felvonultatták, igaz, merőben különböző szempontok alapján reflektáltak a müfaj társadalmi vonatkozásaira.

Az első, klasszikusnak számító, résztvevő megfigyelésen és interjúzáson alapuló szociológiai munka Howard S. Beckerhez (1951) füződik, aki maga is jazz-zongoristaként, már a tudományos pályája kezdetén problematizálta a chicagói jazz-zenészek társas viszonyait és zenével kapcsolatos identitáskonstrukcióit. A több mint fél évszázaddal ezelőtt készült tanulmányban ${ }^{27}$ jelen kutatás szempontjából is meghatározó szempontokra összpontosított: a zenészek identitására egymáshoz és a közönséghez való viszonyukban, a kommersz tánczene és az „extrém jazzt” játszók közti konfliktusokra, valamint a zenésztársaktól és közönségtől való elszigetelődés és distinkció, Becker terminusával „önszegregáció” sajátos mintázataira. A jazztörténészek számára pedig azért bírtak kiemelt fontossággal Becker észrevételei, mert szociológiai szempontokkal árnyalták a populáris és klasszikus zenei gyakorlatokat egyaránt megtestesítő „hibrid” kulturális jelenség (Lopes,

\footnotetext{
${ }^{26}$ Bővebben a számról lásd Zipernovszky és Havas (2017: 7-12) szerkesztői előszavát.

${ }^{27}$ Klasszikus tanulmányát a Chicagói Egyetemen 1949-ben elkészült szakdolgozata alapján írta.
} 
2000), a jazz státuszát alakító tényezőket. ${ }^{28}$ Tanulmányának egyik alapvető következtetése, hogy a zenészek tudatosan elhatárolódnak a hozzá nem értő „kockafejü” közönségtől, továbbá a zenészek közösségén belül is alacsony státusszal bírt a zeneileg alsóbbrendü, puszta szórakoztatásért dolgozó professzionális tánczenészek tevékenysége. Chicago zenei közegében végzett etnográfiai munkáin és résztvevő megfigyelésein alapuló írásai még ma is viszonyítási pontok a kreatív munkavállalással kapcsolatos szimbolikus és anyagi konfliktusokat vizsgáló kutatások számára (Pinhiero és Dowd, 2013).

McIntyre (2001) angol nagyvárosokban végzett kiterjedt, több mint 7000 fős adatgyüjtése során (interjú, kérdőíves és fókuszcsoportos vizsgálat) a müfaj közönségének összetételét, a részvétellel kapcsolatos orientációkat, illetve a jazz népszerűségét kutatta. A kultúrafogyasztás és társadalmi rétegződéssel kapcsolatos egyéb kutatásokhoz hasonlóan megállapították, hogy a (felsö)középosztálybeli szabadfoglalkozásúak felülreprezentáltak a közönség körében. A kulturális mindenevő ${ }^{29}$ fogyasztási szerkezetében Magyarországon is szerepet játszó (Sági, 2010) müfajjal kapcsolatos kutatásuk felvetette problémák tanulsággal szolgáltak a magyar színtér elemzése számára is. A jazz és társmüvészetek közti viszony nem képezte ugyan a kutatás föcsapását, áttételesen sok információt szereztem a jazz státuszáról a klasszikus és populáris zenével való viszonyban. Az angliai kutatás tanulságai arra utalnak, hogy a jazzt egyfajta elitizmus jellemzi, mely a következő fő dichotómiákban ölt testet: (1) a tradicionális mainstream és kortárs jazz-zene ellentétében, (2) az amerikai mainstream (neoklasszikus) és európai avantgárd stílusok közti ellentétben, valamint (3) a jazzre jellemzően háttérzeneként tekinto „,vacsorázó közönség” és a direkt a koncertélmény kedvéért látogató „értő” közönség közti distinkciókban.

Macdonald és Wilson (2005) skót zenészekkel végzett fókuszcsoportos kutatásának néhány aspektusa az interjús kutatás szempontjából szolgált referenciaként. A jazzről folytatott diskurzusokban leggyakrabban a kommersz és magas müvészet, az egyéni és

\footnotetext{
${ }^{28}$ Lopes az amerikai zenei mezőben az '50-es évek második felétől kialakuló zenei áramlatot nevezi a modernjazz-paradigmájának. A jazz müfaján belül különböző stílusokat játszó vegyes társadalmi összetételü zenészek különböző művészi stratégiákon keresztül kapcsolódtak az új zenei erőtérhez. A klasszikus és populáris zenei mezőhöz hasonlóan a jazz is relatív autonómiával bíró erőtérként jött létre az '50-es évekre. A modernjazz-paradigma hibrid természete a populáris, kommersz és magaskulturális gyakorlatok szintézisének tudható be.

${ }^{29}$ A kulturális mindenevők fogalmát Peterson (2005) vezette be arra az empirikus trendre utalva, hogy a magas státuszt egyre inkább eklektikus kultúrafogyasztási minta, vagyis kulturális mindenevés jellemzi.
} 
kollektív kreativitás, a fősodor és újítás ellentétei jelentek meg, melyek magyar jazz kutatása során is alapvető motívumok voltak.

A kutatások egyik fóáramát azon tanulmányok alkotják, melyek a zenészeket kreatív munkavállalóknak tekintik (Hesmondhalgh és Baker 2011; Pinhiero és Dowd, 2013; Umney és Krestos 2013, 2015; Kirschbaum, 2007), s így explicit módon sajátos munkaerőpiaci szegmensbe tartozóként értelmezik a szakma művelőit, akiknek a pénzkereső tevékenységét nem lehet kielégítő módon a bevett közgazdaságtani modellekkel magyarázni. E kutatások közös kiindulópontja, hogy a kreatív iparon belül a jazz-zenészeknek (a szimfonikus zenekarban játszó klasszikus zenészekhez képest is) jellemzően bizonytalanabb a megélhetésük, a stabil munka hiányából fakadóan gyakoriak átmeneti, projektalapú munkák, melyeket nagyfokú kiszámíthatatlanság jellemez, ebből fakadóan a társadalmi tőke és a támogató hálózatok (pl. család) szerepe körükben felértékelődik. Ezen megközelítések leginkább a munkaerőpiaci sajátosságokkal és a kreatív munkavállalók eltérő preferenciáival foglalkoznak, szemben a társadalmi rétegződés és szimbolikus konfliktusok összefüggéseit elemző klasszikus tanulmányokkal (pl. Bourdieu, 1984 [1979]; Peterson és Kern, 1996).

Thorntonhoz hasonlóan Pinhiero és Dowd (2013) is a Bourdieu fogalomrendszerében központi szerepet játszó fogalmakat (tőketípusok, mező) operacionalizálták, ezúttal három amerikai nagyvárosban vizsgálva a társadalmi tőke szerepét a jazzszcénában való érvényesülésben. Elemzésükben a kortárs jazzt egalitárius művészetnek ábrázoló megközelítést árnyalták (Becker, 2000), rámutatva, hogy van egy jól elkülöníthető, domináns magja, privilegizált alcsoportja a színtérnek. Kutatásuk alapján e domináns csoport jellemzői az afroamerikai származás, az idősebb generációhoz tartozás, a szakszervezeti tagság, a magas képzettség és a specifikus lakóhely voltak.

Az ausztrál Rechniewski (2008) történészi szemmel reflektál az ausztrál jazzszcénát érintő főbb problémákra: a rossz infrastruktúrára, az alacsony médiareprezentációra, alulfinanszírozásra, valamint a fragmentált jazzszíntérre, mely okok együttesen járulnak hozzá a kollektív érdekérvényesítés impotenciájához, ami miatt az ausztrál jazzéletet egyfajta „permanens undergroundnak” tekinti. Noha földrajzilag és a müfaj történetikulturális beágyazottságát tekintve természetesen alapvető különbségek vannak a két színtér közt, a fenti problémák a magyar szcénát is jellemzik. 


\subsubsection{Jazz-zenészek mint kreatív munkavállalók}

Umney és Krestos londoni jazz-zenészekkel folytatott interjús kutatásuk eredményeit két tanulmányban rögzítették (2013, 2015). Először arra voltak kíváncsiak (2013), hogy föként a Londonba költöző fiatal zenészek milyen tevékenységtípusok folytán érvényesülnek, és egyúttal mennyire van jelen körükben a kooperációra épülö kollektív cselekvés. A megkérdezett zenészek többsége igyekezett távol maradni a szigorú keretek közé záró kereskedelmi szemlélettől, amely a zenét instrumentummá, a gazdasági profitszerzés eszközévé degradálja. A kutatók szerint a szakmai szolidaritás alacsony szintje és a jazzzenészek rossz munkakörülményei a szimbolikus profitokat az anyagiakhoz képest relatíve nagyobb előnyben részesítő fiatal jazz-zenészek „fatalizmusának” tudhatók be. A jellemzően középosztálybeli háttér biztosította önmegvalósítás révén lehetőségük nyílik kihúzni magukat a munkaerőpiaci szankciók alól. A kreatív autonómia és a kollektív munkakapcsolatok dimenziójában megalkotott koordináta-rendszeren 4 foglalkozási kategóriát különböztettek meg. A kategorizálás során ahelyett, hogy mindegyik zenész munkavállalási stratégiáját külön elemezték volna, 5 reprezentatív stratégián keresztül mutatták be a típusokat.

(1) Az új belépők pozícióját a periferikus csoportba sorolták, ami jellemzően vendégzenészstátuszt jelent, pl. egy házigazda zenekar szervezte jam sessionön. Ide azok a zenészek tartoznak, akik kapcsolatok kiépítése céljából jellemzően alacsony bérért több formációban zenélnek. Mivel a jobb munkakörülmények és bérek kialakítására irányuló érdekérvényesítés gyenge, viszont nagy a túlkínálat, ezért a játszóhelyek is könnyedén tartják alacsonyan a gázsikat. Fontos, hogy a zenészek egy csoportja ragaszkodik ehhez a pozícióhoz azért, hogy minél többet játszhasson. (2) A társulási tevékenységtípus azokra vonatkozik, akik már rendelkeznek kiépített kapcsolathálóval zenei körökben és rendszeresen fellépnek olyan közönség előtt, amely értékeli a tevékenységüket. Ez a tevékenységtípus a gazdasági hasznokat egyéneknek vagy kis csoportoknak (zenei klikkeknek) csatornázza, valamint létrejönnek kölcsönösen támogató kis csoportok, jellemzően egy együttes tagjai, akik müvészileg azonosulnak egymással. (3) Ellentétben a fenti két csoporttal, a vállalkozói tevékenységet üzők elidegenedtek a zenei céloktól, jellemzően céges rendezvényeken és esküvőkön, megrendelésre játszanak. (4) Az elsősorban zenés színházhoz köthető professzionális közösségi tevékenységtípust magas szakmai szolidaritás, biztos munkakörülmények jellemzik, azonban a művészi célok nem játszanak központi szerepet. Kutatásuk talán legkézzelfoghatóbb hátránya, hogy a szcénán belüli 
stílusokhoz és zenei csoportosulásokhoz köthető szimbolikus pozíciókat nem rendelték hozzá a fenti stratégiákhoz. Tehát a mező vagy erőtér belső szerkezetét figyelmen kívül hagyták a fenti típusok megalkotásakor, igaz, a zenei erőtér szimbolikus rétegződésének elemzése nem tartozik a munkaszociológusok szorosan vett kompetenciái közé. Jelen kutatás újdonsága e munkaerőpiaci megközelítéshez képest épp a gazdasági és szimbolikus profitok által kijelölt térben pozicionált zenészek stratégiáinak differenciált ábrázolásában rejlik.

\subsection{Kutatási kérdések bemutatása és a disszertáció felépítése}

Reményeim szerint a fenti sematikus, a teljesség igényét nélkülöző bevezető összegzés meggyőzően illusztrálja, hogy milyen széles körü, kreatív módszertani megközelítések tárgyalják a jazzt mint művészeti világot (Becker, 1982; Becker és Faulkner, 2009), munkaerőpiaci szegmenst (Umney és Krestos, 2013, 2015), vagy a kulturális erőtérbe sajátosan integrálódó relatív autonómiával bíró (al)mezőt (Lopes, 2000, 2002). A bevezető fejezet hátralévő részében a kutatás főbb módszereit, szempontjait, valamint az eddigi kutatási eredményeket összegzem, egyúttal az értekezés fő szerkezeti elemeit, felépítését is ismertetem.

Az összefoglalást nem számítva (6. fejezet) az 5 alapvető szerkezeti egységből álló doktori értekezésem bevezető fejezete utáni elméleti részében (2. fejezet) először kísérletet teszek a kritikai kultúrakutatás (cultural studies) és kultúraszociológiában használt különböző fogalmak (szcéna, szubkultúra, müvészeti világ stb.) koordinátarendszerében elhelyezni a fö elméleti referenciaként alkalmazott mezőelméletet. A különféle kulturális és zenei gyakorlatok egyes szempontjait megragadó rivális koncepciók eltérő tudományos, episztemológiai beágyazottsága és az ezekhez - pl. a birminghami Kortárs Kritikai Kultúrakutatási Központhoz - köthető kutatói tradíciók, a vizsgálódások módszerét és kérdésfelvetéseit, tehát a szociológiai tárgykonstrukciót is meghatározzák. Noha később bemutatott okoknál fogva a relacionális logika alapján konstituálódó, specializált szakértelem monopolizálásáért és annak legitimációjárt folyó küzdelmeket (Hadas, 2001) hangsúlyozó bourdieu-i mezőkonstrukció modellje (Bourdieu, 1991b, 1993, 1996) mellett teszem le a voksom az empirikus elemzéseim során, kutatási gyakorlatomat, így a téma konstrukcióját nagymértékben meghatározza a kritikai kultúrakutatás etnográfiai szemlélete is (pl. Hall és Jefferson, 1975). A mélyinterjús módszer mellett a zenészek közti interakciók mikroszituációinak sűrü leírása, a beszéd- és viselkedésmódok etnográfiai vizsgálata a 
résztvevő megfigyelés (Grazian, 2008) alapvető fontossággal bíró módszerek a szimbolikus különbségtételek logikáját megragadni kívánó kutatásom szempontjából.

Kutatásom ahhoz a kultúraszociológiai tradícióhoz tartozik ugyanis, melyek a müfajokon belüli különbségtételek fontosságára hívják fel a figyelmet (Rimmer, 2012, Varriale, 2014, 2015; Santoro, 2013; Prior, 2013), melyekről a (kultúra)fogyasztás és társadalmi réteghelyzet kapcsolatát nagy mintán vizsgáló kutatások (Peterson, 1992; Peterson és Simkus, 1992; Chan és Golthorpe, 2007; Hanquinet és Savage, 2016; Sági, 2010 stb.) sokszor túlságosan ,általános képet festenek”, figyelmen kívül hagyva az egyes műfajokon belüli distinkciók szélesebb társadalmi relevanciáit. ${ }^{30}$ A kortárs jazzszéna különbségtétel-rendszerének életvitelben, esztétikai alapelvekben, társadalmi réteghelyzetben és etnikum dimenziójában is megragadható jelentéssel bíró megkülönböztető sajátosságai átfogóbb strukturális viszonyokat képeznek le, - e felvetés alapvető állítása a munkámnak és egyben a 2014 ősze óta tartó kutatásom egyik kiindulópontja.

A klasszikus és populáris zenei gyakorlatokat egyaránt megtestesítő, Lopes (2000, 2002) által hibrid „hibridjazz-paradigmának” hívott jelenségből kiindulva, valamint azt tovább gondolva a magyar kontextusban, a mező differenciált leírására teszek kísérletet. Míg Lopes a kulturális termelés mezőjének bourdieu-i tipológiáját árnyalva az amerikai kulturális erőtéren belül egy sajátos (magas és populáris müvészeti gyakorlatokat egyaránt inkorporáló) almező (restricted subfield of popular art) ${ }^{31}$ genezisét írja le, addig a magyar jazz eltérő legitimációs elvekből fakadó hierarchizálódási viszonyainak jellegzetességét már a müfajon belül - a szimultán esztétikai hierarchia fogalmával próbálom meg érzékeltetni. A különböző legitimációkból táplálkozó (Bartók, Kodály, mainstream jazz, free jazz, kortárs szabad és improvizatív zene, népzene, kortárs avantgárd stb.) bináris oppozíciók kifeszítette jazz-zenei mezőt alkotó relációk szerkezete és dinamizmusa kevésbé ragadható meg a „heteronómia” (piac), ,,autonómia” (szimbolikus profitok) és „,ortodoxia” alapelveivel

\footnotetext{
${ }^{30}$ Erről részletesen lásd pl. Rimmer (2012: 313) és Atkinson (2011) cikkeit.

${ }^{31}$ Lopes (2000: 173) terminusa (the restricted subfield of popular art) a bourdieu-i „tömeges” (la grande production) és „,korlátozott” (production restreinte) termelés megkülönböztetését veszi alapul, melyet magyarra a „populáris müvészet autonóm almezöjének” fordítok, az eredeti bourdieu-i terminus szöveghübb, (sous-champ de production restreinte), ám magyarul talán döcögősebb „populáris müvészet korlátozott almezője" kifejezés helyett. Ahogy az elméleti részben kifejtem, alapvetően - legalábbis rövidtávon (Bourdieu, 1993 ) - olyan almezőről van szó, amelyben a termelők vesznek részt, ezért meglátásom szerint az „autonóm” fordítás is megállja a helyét.
} 
(Savage és Silva, 2013; Varriale, 2016), mint ahogy a mezőelmélet ezt sugallná. Kiváltképp a piac (heteronómia) és szimbolikus profitok (autonómia) - az esztétikai hiearchizálódás „autonóm” és „heteronóm” - alapelveinek oppozíciója bír kisebb magyarázó erővel az erőtér dinamizmusára, a pozíció- és presztízsszerzés logikájára vonatkozóan, mint a történetileg kondicionált jazz-zenei mezőt strukturáló free és mainstream pólusokhoz köthető oppozíciók. „Kvázi-etnográfiai” elemzésem során pont e történetileg kondicionált kontextuális pluralitásban találom meg az eltérő legitimációs elvek és habitusok generálta osztályozott és osztályozó praxisok sajátos dinamizmusának strukturális alapját, röviden, a meződinamika logikáját a kortárs magyar jazz-zenei erőtérben.

A mezőelméletből kiinduló kortárs kultúraszociológiai kutatások pl. (Rimmer, 2012; Varriale, 2015, 2016, Regev, 2013) az autonómia és piac oppozíciójának magyarázó erejét specifikálják újonnan létrejövő kulturális mezők (elektronikus zene, populáris zene kritika, jazz stb.) kontextusában (Prior, 2008, 2011). E munkák egyik közös eleme annak hangsúlyozása, hogy heterononóm (piacorientált) gyakorlatokat a hierarchizálódás autonóm pólusain is felfedezhetjük, pl. egyes avantgárd müfajok esetében, és a szimbolikus profitok megszerzéséért folytatott küzdelmeknek a „kommersznek” titulált heteronóm póluson is előfordulnak (Varriale, 2015: 14). A legkülönfélébb populáris kulturális, illetve a kulturális legitimitások perifériáján lévő művészi gyakorlatokat (elektronikus zene, jazz, rock stb.) tárgyaló kutatások inkább a mezőelmélet gazdagságáról, annak különböző, többnyire alulkutatott populáris zenei kontextusokban történő alkalmazásainak izgalmas lehetőségeiről tesznek tanúbizonyságot, semmint arról, hogy az elmélet kisebb magyarázó erővel bírna ezekben a (populáris) zenei kontextusokban.

A kortárs populáris zenei erőterek empirikus összefüggéseinek vizsgálata alapján tehát Bourdieu-kritikus és nem Bourdieu-tagadó kutatási horizontból kiindulva azért kifejezetten izgalmas terep a (kortárs) jazz, mert a „magas” és populáris művészi gyakorlatokból egyaránt merítő „kvázi-felszentelt” (semi-consecrated) (Varriale, 2015: 4) műfajban a pozíció- és presztízsszerzések logikája sajátos alapelveken nyugszik. Az elméleti részben, végül, a „posztbourdieu-i” zeneszociológia diskurzusokban is pozicionálom a munkám (De Boise, 2016; Prior, 2008, 2013), azon kutatások közé sorolva azt, melyek az adott empirikus kontextusnak megfelelő finomhangolást tüzik ki célul (De Boise, 2016: 179) a mezőelmélet „paradigmáján” belül maradva, és nem negligálva az elmélet koncepcionális építményének 
kutatói praxist is elöíró alapelveit (Bourdieu, 1993, 1996). ${ }^{32}$ Végül, a kurrens, nemzetközi szakirodalomban bevett mezőelemzéssel (Savage és Silva, 2013) (field analysis) összefüggö újdonságát is hangsúlyozom a kutatásomnak, mely az etnográfiai eszközkészlet mellet, a szimbolikus különbségtételeket alapvetően mélyinterjúkra támaszkodva, a diszkurzív konstrukciók alapján rekonstruálja, egy - mind magyar és nemzetközi szinten is szociológia által meglehetősen alulkutatott területen. ${ }^{33}$

A kutatás főbb módszertanát áttekintő 3. fejezet, az elméleti rész folytatásaként is értelmezhető, mert a mezőelmélet heurisztikus ereje nem csak a bourdieu-i fogalmi háló komplexitásának elméleti kvalitásaiban rejlik, de a kutatói praxis episztemológiai alapvetéseit kijelölő lényegileg módszertani értékei miatt is (Savage és Silva, 2013: 118). E fejezet valódi tétjét nem csak a most is bemutatott interjúzás és terepmegfigyelés - a kutatás kimenetele szempontjából nyilvánvalóan releváns - körülményeinek részletezése adja (milyen releváns szociológiai változók mentén, kikkel, mennyi időt interjúztam, hol végeztem a terepmegfigyeléseket és mely szempont alapján, milyen kódolási elvet alkalmaztam stb.), hanem a mezőelmélet implicit és explicit módszert elöíró téziseinek operacionalizálsa. Vagyis az, hogy a típus- és modellalkotás igényével hogyan ültettem át, operacionalizáltam a mezőelmélet esztétikai hierarchizálódásra, pozíció- és státusszerzésekre, társadalmilag és habituálisan kondicionált ki- és elsajátítási játszmák logikáját megragadni képes módszertani-episztemológiai alapvetéseit (pl. Bourdieu, 1993). A fő kihívás abban állt, hogy a relációk terét a különböző pozíciókat betöltő jazz-zenészek megkülönböztető és megkülönböztetett osztályozási elvei alapján konstruáljam meg. Bourdieu-t parafrazálva, az interjúelemzés tétje a különböző pozíciók „egy pillantás sugarában való összesürítése volt”, mely pozíciókat az ágensek sohasem képesek felfogni a maguk totalitásában (Bourdieu, 2010: 169). Összegezve, e fejezetben a vizsgált mezőt alkotó relációk komplexitására érzékeny (interjú)elemzői módszer kialakítását részletezem, melyet kiegészít a kutatói pozíciómra való reflexió és az adatgyüjtés ismertetése.

A kutatás során - az 5 ,follow up” interjút nem számítva - 27, átlagosan másfél óráig tartó félig-strukturált interjút készítettem, így közel 50 órányi interjú manuálisan kódolt

\footnotetext{
${ }^{32}$ Elemzésem során magam is hangsúlyozottan építek Bourdieu azon írásaira, amelyben hangsúlyos szerepet kap a korlátozott és tömeges szimbolikus termelés mezőinek egymáshoz való viszonya (különösen Bourdieu, 1993: 115-120 és 125-131).

${ }^{33}$ Az esztétikai hierarchiák mezőlméletből kiinduló elemzéseinél a mélyinterjús módszer viszonylag ritkának számít a kultúraszociológia berkein belül, kiváltképp a jazz kontextusában, melynek hangsúlyozására Simone Varriale szociológus hívta fel a figyelmem, amit ezúton is köszönök neki.
} 
transzkripcióját készítettem el, eltérő zenei irányzatot képviselő, generációt és származást tekintve is különböző jazz-zenészekkel. A 27 interjú közül kettőt 2-3 fős minifókuszcsoportban valósítottam meg. A legfiatalabb interjúalany 19 éves, a legidősebb 60 éves volt, az interjúk többségét 25 és 45 éves hangszeres zenészekkel végeztem. A módszertani fejezetben a reflexíven kezelt erősen maszkulin minta jellegéről további, részletező megjegyzéseket teszek és kifejtem, mely szempontok szerint kódoltam az átiratokat. A mező fontosabb relációit és az abban müködő különböző tőkéket, más később kifejtett szempontok mellett, olyan feltáró kérdések hétköznapi megfogalmazásával igyekeztem megragadni, mint:

- Kik tartoznak a jazz-szcénába? Milyen szempontok szerint? Mi a szerepe ebben a Zeneakadémiának/ konzi(k)nak?

- Milyen „belépési adó”34 - technikai és esztétikai elvek, képességek és készségek stb. - mentén definiálódik a jazz-zenész?

- Vannak-e különbségek a különböző generációhoz, etnikumhoz és stílusokhoz tartozó zenészek közt abban, mit tekintenek legitim jazz-zenei praxisnak?

- Milyen képességek tekinthetők tőkének az erőtérben?

- Milyen kooperációs mintákat és konfliktusokat észlelnek a szcénában a jazzzenészek, ez alapján mennyire látják azt fragmentáltnak?

- Különböző csoportok kikkel játszanak és kikkel nem játszanak szívesen? Miért?

- Hogyan viszonyulnak kanonikus figurákhoz (Charlie Parkerhez, Miles Davishez stb.) a jazz-zenészek és milyen szempontok alapján interpretálják e referenciákat? Említenek-e kifejezetten „ellenreferenciákat” egyes jazz-zenészek kapcsán?

\footnotetext{
${ }^{34}$ A ,belépési adó” kifejezés alatt Wessely Annát (2012: 67) idézve a következőt értem: „a mezöspecifikus ismeretek és kompetenciák megszerzésének költsége-, amit az egyének többnyire (legalább felsőfokú) képzésük költségeinek formájában rónak le”. Noha egy korábbi, 2005-ös cikkében a „,belépési költség”, vagy ,jogcím” kifejezést preferálja, legalábbis Bourdieu (2005) Collège de France-ban tartott 2000-2001. évi előadássorozatának magyar verziója kapcsán a hanyag fordítások egyik példájaként említi a droit d'entrée „belépési adónak” történő fordítását (Wessely, 2005: 230). Később már használja a kifejezést, jóllehet annak fent is olvasható magyarázata előtt, először idézőjelben (Wessely, 2012: 67). Az értekezés során e kifejezést én is idézőjel nélkül használom, a később részletesen bemutatott mezőelmélet fogalmi hálójának ismeretében ugyanis egyértelmű, hogy a mezőkonstrukció kontextusának megfelelően „,belépési költségnek” is fordítható (az angolban az „entrance fee” a bevett használat) „,belépési adó” mire is utal.
} 
A mélyinterjúkat önreflexív terepmegfigyelések, informális beszélgetések és egy illusztratív kérdőíves kutatás $(\mathrm{N}=37)$ egészítette ki. A kérdőíveket az Etüd Konzervatóriumban és a Liszt Ferenc Zeneakadémia Jazz Tanszékén töltöttem ki ${ }^{35}$ fiatal jazz-zenészekkel, és Ser Ádámmal közösen elemeztem (Havas és Ser, 2017). A kvantitatív rész azonban csupán kiegészítése a föként félig-strukturált interjúk elemzésére építő kutatásnak, mely az interjúvázlatban szereplő kérdésfelvetéseket árnyalta. A lekérdezések során fontosnak tartottam jelen lenni a képzőhelyeken, így az esetlegesen felmerülő kérdésekre egyrészt helyben tudtam válaszolni, segíteni a kitöltőt, illetve így meggyőződhettem róla, hogy az osztályok ahol a kitöltés zajlott valóban kitöltik azokat.

A terepmegfigyeléseket jazz klubokban (pl. Budapest Jazz Klub, Opus Jazz Klub), élő jazz-zenét rendszeresen programon tartó kávéházakban és különböző bárokban végeztem. Az egy időben a Hadik, Központ és Magvető kávézókban jazz koncerteket szervező, számos jazz zenésszel már jóval a kutatás megkezdése előtt baráti ill. jó viszonyt ápoló kutatói pozíciómat, a bennfentesség folyamatának mérföldöveit is e fejezet során részletezem önreflexív módon. A tengernyi informális beszélgetésröl és különböző, (föleg zenészek közti interakciókat érintő) résztvevő megfigyeléseimről terepnaplót vezettem: a mellékletben közölt interjúvázlat kérdéseit tehát folyamatosan megkérdőjeleztem, illusztráltam, vagy alátámasztottam etnográfiai tapasztalataimmal. Kutatásom jó példája továbbá a magyarul „megalapozott” és „alapozott elméletnek” is fordított (Kucsera, 2008) „grounded theory” módszerének (Glaser és Strauss, 1967; Glaser, 1992), mely a bejövő adatok és elmélet folyamatos reflexióval kísért összevetését hangsúlyozza, vagyis kutatási kérdéseim az évek során, amit a magyar jazzszénában töltöttem folyamatosan finomodtak, a tapasztalataimat újra és újra beépítettem a soron következő interjúkba és megfigyelésekbe.

A doktori disszertáció empirikus részeit a 4. és 5. fejezetekben kifejtett elemzések adják. A Különbségtételek rendszere a mainstream - free jazz distinkcióban címü 4. fejezetben a müfajon belüli distinkciók és rétegződés összefüggéseinek esztétikai, tradícióértelmezéssel és meghatározott esztétikai pozíciókhoz kötött megélhetési stratégiáival kapcsolatos szempontjait elemzem, ahol a free és mainstream jazz különbségtétel (distinkció) alapvető, strukturális fontosságú tényezőnek bizonyult. Az interjúelemzések során a fejezetben a mellett sorakoztatok fel érveket, hogy a „tiszta” free és mainstream pólusok jól rekonstruálható oppozíciós rendszerré állnak össze (lásd az 1. táblázat oppozíciós párjait), melyek alapvetően meghatározzák az esztétikai praxisokat és a

\footnotetext{
${ }^{35}$ Amiért köszönet illeti Binder Károly, Friedrich Károly és Párniczky András tanár urakat.
} 
presztízsszerzés alapelveit. A fejezetben elemeztem pl. a különböző pozíciók jazztradícióhoz való viszonyát, rekonstruáltam kiket tekintenek referenciának a magyar és a nemzetközi jazzvilágból, milyen szempontok alapján, majd a tradícióértelmezésekhez kapcsolódó praxisokat kondicionáló osztályozási elveket és racionalizálási stratégiákat vizsgáltam. E fejezetben csak érintettem a legalább az 1970-es évekre visszavezethető, akkor már (fesztiválokban, szaklapokban, koncerthelyek formájában stb.) intézményesedett különbségtétel strukturális-történeti alapjának kérdéskörét, nevezetesen a free és mainstream jazz szélesebb társadalmi és etnikai meghatározottságát, vagy finomabb - és elemzéseim során föleg ezt használom - szóhasználattal: kondicionáltságát. A jóval etnografikusabb 5. fejezetben árnyalom majd tovább az itt megfogalmazott egyik fő hipotézist, mely szerint a főként cigányzenész családból - származó roma jazz-zenészek mainstream jazz-szel kapcsolatos esztétikai dogmatizmusa a társadalmi erötérben való legitimációval, és a történetileg kondicionált, esztétikai praxisok generáló elveként tételezett zenei habitusokkal van összefüggésben. A cigányzenész felmenőkkel rendelkező, de már (mainstream) jazzt játszó magyarcigány zenészek számára a magas kultúra asszociációval rendelkező jazz-zene a társadalmi integráció egyik meghatározó kulturális aspektusa.

A különböző pozíciókat elfoglaló zenészek fontosabb referenciáinak és jazzkánoninterpretációjának kvalitatív elemzése alapján továbbá kísérletet teszek az alapvető fontosságúnak tételezett jelenség, a szimultán esztétikai hierarchia államszocializmusra visszanyúló történeti-strukturális alapjának megragadására is. E hosszabb fejezet záró részében a kreativ munkavállalóknak tételezett free és mainstream jazz pozíciók megélhetési stratégiáiban való eltéréseit és összefüggéseit is vizsgálom, vagyis azt, hogy a heteronómia és autonómia strukturáló elvei milyen stratégiákban jelennek meg - már nem a szimbolikus distinkciók és esztétikai referenciák, illetve zenei „szekták”, vagy táborok létrejöttében -, hanem a megélhetéshez szükséges praxisok szintjén. E módszer a fent bemutatott munkaszociológiai kutatásokhoz (Umney és Ketsos 2013, 2015) képest annyiban újdonság, hogy a megélhetési stratégiákat a hierarchizált viszonyrendszer és szimbolikus különbségtételek kontextusában értelmezi: tehát a mezőnek tételezett jazzszcéna viszonyrendszereinek szerkezetéből indul ki. Továbbá, mintegy illusztrációképpen itt közlöm a kérdöíves kutatás eredményeit is.

Végül, A kortárs jazz esztétikai és etnikai konstrukciói: „,cigány jazz” és zenei habitus címü 5. fejezetben, az etnikumhoz köthető jelentéssel bíró megkülönböztető sajátosságok diszpozicionális elemeit (értékelési, észlelési és kognitív sémáit) a bourdieu-i habitusfogalom nyomán alkotott zeneihabitus-koncepcióval (Rimmer, 2012) vizsgálom, 
különös tekintettel a zenei szocializáció, rokonság, életstílus és az esztétikai distinkciók szempontjaira. Noha a foglalkozással definiált társadalmi csoport, a „zenész cigányság” fontos szerepet tölt be a populáris zene fejlődésében Magyarországon, a szociológia módszereivel idáig nem elemezték e dominált etnikum domináns (urbánus, többnyire „magyarcigány” jazz-zenész) frakciójának kulturális legitimitások hierarchiájában betöltött pozícióját a kortárs jazz szemszögéböl. A sürü leírásokban, interjúelemzésben és számos egyéb forrás - videók, interjúk, de CD borítók és számcímek szimbolikájának interpretációjában gazdag alfejezetekben, a következő hipotéziseket is megpróbálom árnyalni:

- A cigányzenészek számára a jazz olyan terep - szemben a többnyire a többségi társadalom közép és felső rétegeiből rekrutálódó ügyvédi, vagy orvosi pályákkal (Gáti 2010) - ahol a zenéből élés generációs tradíciója biztosította zenei diszpozíciók és kompetenciák átörökítése folytán, nem csupán kompetitív viszonyba kerülnek a többségi társadalom tagjaival, de föléjük is tudnak kerekedni.

- Továbbá, a „cigány jazz” esztétikai és etnikai konstrukcióinak vizsgálata során arra kérdésre keresem a választ, hogy a jazz-szel összefüggő esztétikai kérdések mennyiben etnicizáltak Magyarországon, valamint mennyire tekinthetö „tőkének” a származás a jazz kontextusában.

Elemzésen egyik fő következtetése szerint, a mainstream és free jazz distinkció kontextusában a zenei praxisokat és jelentéssel bíró hierarchizáló különbségtételeket generáló zenei habitus a cigány származású jazz-zenészek körében a rokonság közvetítette, zenei szocializáció során kondicionált zenei „,anti-intellektualizmusban” ragadható meg, szemben az autonóm művész ethoszát hangsúlyozó, tudós referenciákra építő „intellektualizáló” praxisokkal és (ön)értelmezésekkel. ${ }^{36}$ Ezen felül habitusvariációkat is megkülönböztetek az öndefiníció során a vérvonalat és genetikát (!) hangsúlyozó, a zenei készségeket „doxikus tapasztalatként” megélő „fanatikus” jazz-zenészek ${ }^{37}$ és a cigány jazz-

\footnotetext{
${ }^{36}$ Ehhez lásd pl. a „fanatikus”, professzionalista jazz-zenész és a zenei szempontokon túlmutató „,autonóm müvész ethoszának" ellentétét 4. fejezetben.

37 „Fanatikus” alatt, ahogy a későbbi elemzésemből részletesebben kiderül (5. fejezet) a jazz köré szervezett életstílust értik.
} 
zenészek eme „arisztokratikusnak” tételezett csoportjának ,zenei rasszizmusától” (sic!) távolságot tartó szélsőséges cigány származású jazz-zenész pozíciók, illetve csoportok között. Mindkét empirikus fejezet során igyekszem hangsúlyozni, hogy az értekezés során megkülönböztetett különbségtételek hierarchizáló rendszerének különböző aspektusai nem egy merev és zárt erőtér szerkezetének képét festik le, de egy dinamikus erőteret és „relációrendszert”, ahol a presztízs- és pozíciószerzések a 4. és 5. fejezetekben kifejtett dimenzióin túl átjárások is lehetségesek. Mindazonáltal, a disszertáció során a mellett (is) érvelek, hogy a mélyinterjúkból, illetve megfigyelésekből rekonstruált „szélső pólusok” megfelelő analitikus eszköznek bizonyulnak a mező szerkezetének szociológiai megragadásához.

Az elemzésből a fenti kutatási szempontokon és kérdéseken túl a kortárs budapesti szcéna szerkezeti sajátosságai mellett fontos - további kutatásokat igénylő háttértényezőként kirajzolódnak a jazz klasszikus zenéhez képesti alárendelt státuszával összefüggő intézményes aspektusok, valamint a jazz legitimitás-küzdelmei a kortárs kulturális erőtérben.

\section{5. Összefoglalás}

A bevezető fejezetben először a jazztanulmányok nézőpontja felől közelítettem a kortárs jazzszcéna rétegződését vizsgáló, főként kultúraszociológiai referenciákra támaszkodó „kvázi-etnográfiai” kutatásomhoz. Fontosnak tartottam hangsúlyozni, hogy a nagy presztízzsel bíró egyetemeken oktatott, kb. 70 éve létező és intézményesült diszciplína a jazzre mint zenén túlmutató kulturális gyakorlatra tekint, melynek tanulmányozása szemben pl. a zenetudományi nézőpontokkal - számos etnikummal, rasszal, kultúrpolitikával, zeneiparral és általánosabb kulturális distinkciókkal összefüggésekre mutat rá. A ,jazztudós” (jazz scholar) valójában egy történet-, társadalom- és kultúratudományok módszertani és elméleti megközelítéséből táplálkozó, a műfajjal önreflexív viszonyban lévő kutató, aki a jazzen keresztül igyekszik megragadni különböző, a fenti területekkel összefüggő kérdéseket és jelenségeket. A kutatás során képviselt elméletileg orientált szociológiai kutatás nézőpontjával a jazztanulmányok megközelítése annyiban analóg, amennyiben meggyőződésem szerint a társadalmi-kulturális jelentőségéhez képest meglehetősen alulkutatott magyar jazz müfajon túlmutató összefüggéseit és relevanciáit hangsúlyozza. 
Magyarországon egészen az utóbbi évek néhány jelentékeny kezdeményezéséig ${ }^{38}$ nem alakult ki tudományos diskurzus a müfaj jelentőségéről, ahogy jóval magasabb legitimitással bíró, nemzetközileg is méltán világhírü komolyzenéről sem készülnek (zene)szociológiai kutatások, kortárs irodalomszociológiai, vagy átfogóbb művészetszociológiai kutatásokról nem is beszélve. ${ }^{39}$ Azt nem tudom, hogy a szociológia állítólagos hármas válságával (Szelényi, 2016), a közgazdaság és racionális döntés-elméletének kolonizáló tendenciáihoz való igazodással (Hadas, 1998), pályázat- és forráselosztással (Somlai, 2001), a politikai és gazdasági erőtereknek való kitettséggel, a történetileg kondicionált „,paradigmafüggéssel” paradigmavaksággal? - (Hadas, 1992), vagy a közép-európai szociológia kognitív esélyének esetleges „elszalasztásával” (Wessely és Csepeli, 1992) van összefüggésben, de a művészetés kultúraszociológia viszonylag marginális pozíciót tölt be a magyar tudományos erőtérben. Annyi legalábbis bizonyosnak tünik, hogy más nemzetek (amerikai, brit, német, francia stb.) szociológiájával ellentétben, a magyar (társadalom)tudományosság nem „emésztette meg és dolgozta újra" (Prior et al., 2017: 4-5) a kutatásom számára referenciaértékü, a nemzetközi (kultúra)szociológiában nagy presztízsű, ,„mainstream-nek” számító mezőelméletet. ${ }^{40}$ Ebből kifolyólag a lokális specifikumra, sajátos történeti fejlődésből fakadó társadalmi-kulturális kontextusokra, valamint a szociológia müvelésének nemzeti hagyományaira a kutatói praxis során reflektáló „magyar Bourdieu-ről” nem beszélhetünk, ahogy ezt tehetjük pl. Anglia, Németország vagy az USA esetében. A mélyinterjúkra és etnográfiai módszerekre támaszkodó kutatásom, erre a „magyar Bourdieu” létrehozására és a „,mezőelemzés” (field analysis) emancipációjára irányuló hiánypótló hozzájárulásnak is tekinthető, - reményeim szerint legalábbis.

${ }^{38}$ Ezek közé tartoznak a már említett Americana e-journal és Replika tematikus különszámok, a Made in Hungary Routlegde kötet (Barna és Tófalvy, 2017) stb.

${ }^{39}$ A diszciplínáról széles ecsetvonásokkal festett borús képet meglátásom szerint jól illusztrálja Wessely Anna beszámolójának itt kiragadott rövid részlete egy az ELTE TÁTK és TÁRKI szervezésében 2008/2009-ben megvalósított kutatásról (A kortárs magyar müvészet társadalomszerkezete): „Ha ma lenne pénzügyi lehetőség empirikus müvészetszociológiai kutatásra, akkor azt a kutatást folytatnám, bövítenem ki, amelyet... (Wessely, 2012: 65)."

${ }^{40}$ Sőt, mintha Bourdieu kapcsán a „tárgydekonstrukció” hamarabb menne végbe (lásd pl. Hadas, 2002, 2015), mint a tárgy- vagy témakonstrukció, ha csak az empirikus kutatásokat vesszük alapul. A mezőelmélettel is kacérkodó munkák ezt legalább annyira látszanak alátámasztani, mint a munkák hiánya, illetve egyes magyar fordítások egyébként a disszertációban is tárgyalt komoly hiányosságai. lásd Hadas (2002) és Wessely (2005). 


\section{ELMÉLETI HÁTTÉR}

\subsection{A magyar jazzszíntér konceptualizálása: versengő koncepciók ${ }^{41}$}

Varriale (2014: 50) zene és társadalom kapcsolatának három olyan dimenzióját különíti el, amelyek a kortárs zeneszociológiai irányzatokban is megjelennek. E három „dimenzió” a (1) zene esztétikai autonómiájával és társadalmi cselekvést befolyásoló képességével, a (2) zene társadalmi különbségekbe való beágyazottságával, (3) valamint a zene globális

${ }^{41}$ Az elméleti fejezet legelején kénytelen vagyok egy hosszabb lábjegyzetben A müvészet szabályainak (Bourdieu, 2013 [1992]) angol (1996) és magyar (2013) fordításaival kapcsolatos néhány orientáló megjegyzést tenni. Az értekezésem szempontjából a Kulturális termelés mezöje (Bourdieu, 1993) mellett alapreferenciaként szolgáló művet először angolul Susan Emanuel fordításában olvastam. E fordítás minőségéről, felhasználhatóságáról egyrészt Hadas Miklós konzulensemmel folytatott megbeszélések, másrészt a szakma által hitelesnek tekintett Ádám Péter- és Léderer Pál-féle korábbi Bourdieu-fordítások alapján győződhettem meg ,amelyek nyomán Bourdieu terminusai meghonosodtak a magyar szaknyelvben” (Wessely, 2005: 229). A magyar verzió 2013-ban jelent meg Seregi Tamás fordításában, aki a fordítás kézirátát röviddel megjelenés elött maga bocsájtotta rendelkezésemre, amit ezúton is hálásan köszönök neki. A doktori értekezés során itt részletezett okoknál fogva egyes szószerinti magyar idézetnél a Seregi-féle fordításra támaszkodom, egyébként következetesen az angol 1996-os verziót használom. Bizonytalan franciatudásom folytán az eredeti fordítására nem vállalkozhattam, az angolra fordított verzió az értekezés fejezetei szempontjából fontos, egyes hosszabb passzusait pedig nem állt szándékomban úgy lefordítani, hogy már létezik magyar fordítás, amely azonban - amennyire meg tudom ítélni - kevésbé érzékeny a bourdieu-i szociológia nyelvezetének finomságaira, illetve a fogalmi hálót meghonosító és alkalmazó társadalomtudósok (pl. Ádám Péter, Léderer Pál, Ferge Zsuzsa, Wessely Anna, Hadas Miklós, Babarczy Eszter, vagy Fáber Ágoston) fordítói-szerkesztői és/vagy szerzői munkássága nyomán létrejövő magyar szociológiai diskurzusra. A diszpozíció terminus „hangoltságnak” (pl. 2013: 146), a tiszta termelés pólusa „tiszta alkotás pólusának” (2013: 141), vagy a differenciálás „,megkülönböztetésnek” (2013: 143) fordítása ilyen példák, nem beszélve a magyar szakirodalomban általában tömegtermelésként vagy tömeges termelésként bevett „,nagytermelés” fordítói megoldásról (ami egyébként megfelel a „grande production” eredeti franciának). A szemiotikai zürzavart kerülendő, megfelelő franciatudás hiányában a hosszabb szószerinti idézeteknél a Seregi-féle verziót használom lábjegyzetekben jelezve az esetleges módosításokat. Az angol verzió egyes részeinek fordítását azért sem közlöm minden esetben saját fordításomban, mert a transzdiszciplináris, terminusokban tobzódó, többszörösen összetett és bővített mondatokkal operáló bourdieu-i nyelvezet fordítása során akkor is a gyakorlott - többek közt Sartre Lét és a semmi c. müvét is lefordító! - Seregi magyar fordítását venném alapul, ha az irodalomtudományi és esztétika-filozófiai háttérrel bíró fordító egyes megoldásai nem is adják vissza a bourdieu-i paradigma lényegét a mú kontextusában. A fordítással kapcsolatos egyes megjegyzéseimről ugyan igyekeztem kikérni (pl. már Bourdieu-t fordító) szakértők véleményét, ami nem sikerült minden esetben. Az esetleges értelmezési hibákért ettől függetlenül maximálisan vállalom a felelősséget. Az angol verzió saját fordításainál az eredeti szöveget lábjegyzetben közlöm a könnyebb összehasonlitás kedvéért. 
terjesztésével függ össze, mely irányzatok közt persze számos átfedés is tapasztalható a kutatások orientációjától függően (Marshall, 2011). A „mezővel” párhuzamosan az „erőtér”, „szcéna” és „színtér” fogalmait is alkalmazom elemzésem során, mely leginkább a második típusba, vagyis a (szimbolikus, gazdasági stb.) különbségtételekkel kapcsolatos megközelítések közé sorolható. ${ }^{42} \mathrm{Ez}$ utóbbin belül is megkülönböztethetünk müfajok közötti, társadalmi egyenlötlenségekkel összefüggő státuszküzdelmekre (Lopes, 2002) koncentráló, és egyes müfajokon belüli variációkat (intra-genre variatons) előtérbe helyezö kutatásokat (Rimmer, 2012). E fenti két kategória közül kutatásom az utóbbiba esik, mivel a müfajon belüli distinkciókat igyekszem feltárni, mi több, modellszerüen bemutatni a kortárs jazzszíntér hierarchizált viszonyrendszerében. Az elméleti fejezetben a DiMaggio és Becker nevével fémjelzett institucionalista és interakcionista megközelítéseket (Maanen, 2009), Bourdieu homológia-tézisének kritikáit (Peterson, 1992, Peterson és Simkus, 1992; Lamont, 1992), az erről kialakult diskurzust (Peterson, 2005; Atkinson, 2011), valamint a magyarázó változóként tételezett - zene társadalmi mozgalmakban betöltött szerepéről szóló irodalmakat (pl. Frith, 1996) nem tekintem át részletesen. ${ }^{43}$

Egy zenei stílushoz köthető kulturális közösség elemzésére számos, a különböző társadalomtudományokban gyökeret vert fogalom áll rendelkezésre. Az elemző helyzetét nem könnyíti meg, hogy a rendelkezésre álló versengő koncepciók (Hesmondhalgh, 2005) széles tárházán kívül (szubkultúra, mező, ifjúsági kultúra, neotörzs, szcéna, müvészeti világ, miliő stb.) ${ }^{44}$ sok esetben egy adott fogalom alatt a kutatások különböző (etnikai, kisebbségi, kulturális) csoportokat értenek (Kacsuk, 2005). A fó elméleti referenciaként hivatkozott mezöelemzés melletti elköteleződést a fenti koncepciókhoz köthető kutatási irányzatok mérlegelése előzte meg. A kutatás szempontjából fontos kérdésként merült fel a kultúraszociológiában jelentős tradícióval bíró „mező”, „művészeti világ”, „szcéna”45 és

\footnotetext{
${ }^{42}$ Lásd pl. Rimmer (2012), Lopes (2000) vagy Varriale (2015).

43 Lásd 2.5. fejezet vonatkozó részeit a homológia-tézis (kvalitatív) kritikáiról és a mikroszociológiai megközelítésekről (Hennion, 2007; DeNora, 2010).

${ }^{44}$ A chicagói iskoláig visszanyúló szubkultúra-elméletekről lásd Kacsuk (2005), Cohen (1972) írásait vagy a Gelder és Thornton (1997) szerkesztette tanulmánykötetet. A mező, művészeti világ, szcéna, neotörzs és ifjúsági kultúra szociológiai koncepcióiról sorrendben lásd Bourdieu (1993, 2003, [1972]), Becker (1982), Straw (1991), Bennett (1999) és Bennett és Hodkinson (2012).

45 A szcénakoncepció a populáriszene-kutatás diszciplínájában (is) is kulcsfogalom. A zenét különböző szempontok szerint kutató különböző (al)diszciplínák (pl. zeneszociológia, kultúraszociológia, etnomuzikológia stb.) között a határ sokszor elmosódik.
} 
„szubkultúra” terminusainak alkalmazhatósága. Az interjús kutatás előrehaladott szakaszában, mikor elegendő belső információ állt rendelkezésre a budapesti jazzélet stílusok és generációk szerinti szegmentálódásáról, már tudatosult, hogy leginkább az első három kerül az érdeklődés fókuszába, főként azért, mert a szubkultúra-fogalom kultúraszociológiai konnotációi (Thornton, 1995; Bennett, 2000; Kacsuk, 2005) kevésbé ragadják meg a vizsgált közösség interjúkban markánsan megjelenő belső fragmentáltságát és a színtér határának elmosódását. Az elemzések során alkalmazott elméleti koncepciók kritikai kiválasztását megfigyelések és interjúk előzték meg. A számos elmélet és megközelítés közül föleg azokat említem az elméleti fejezetben, melyek a budapesti jazzszcéna konceptualizálásához és kutatási kérdések szempontjából kifejezetten fontosak voltak.

\section{2. Szcéna- és szubkultúrakutatások}

Lássuk először a szubkultúra fogalma kapcsán felmerülő néhány fontosabb megfontolást. A birminghami Kortárs Kritikai Kultúrakutatási Központhoz ${ }^{46}$ kapcsolódó, mára kanonizált szerzők (Cohen, 1972; Hall és Jefferson, 1975; Hebdige, 1979) az általuk vizsgált (mod, motoros, punk, teddy boy stb.) szubkultúrák viszonyait szélesebb hierarchizált osztálykonfliktusok színrevitelének tekintették (Ritzer és Smart, 2003; Ritzer, 2010). ${ }^{47}$ A munkásosztály oktatásában személyesen is résztvevő Richard Hoggart és Raymond Williams ,alapítóatyák” a kritikai kultúrakutatásban (cultural studies) a társadalmi változás egyik instrumentumát látták, mely az elsők közt tételezte legitim kutatási témának az ifjúság kultúráját és vizsgálta a médiaapparátus szerepét a hatalmi viszonyok fenntartásában és újratermelésében. Az ifjúsági szubkultúrákat többnyire ellenhegemón mozgalmakként értelmezték, mely a domináns osztályokat kiszolgáló, az elnyomó viszonyokba való viszonylagos beleegyezést fenntartó mediatizált kultúriparral szemben osztályalapon pozícionálta magát. A Frankfurti Iskola „,passzív közönség-koncepciójával”, ${ }^{48}$ valamint a

\footnotetext{
${ }^{46}$ A Központot (Center for Contemporary Cultural Studies - CCCS) Richard Hoggart hozta létre 1964-ben.

${ }^{47}$ A CCCS-hez kapcsolódó (szubkultúra)kutatási irányzatokról Ritzer és Smart (2003) mellett Kacsuk (2005) is átfogó összefoglalást nyújt, tárgyalva a fogalomhoz köthető kritikai és alternatív megközelítéseket.

48 Adorno tömegkultúra-kritikáját jól illusztrálja a következő idézet „a tömegkultúra hamis szükségletek ébreszt, fogyasztói pedig kábitószerfüggők módjára habzsolják önnön szellemi leépülésük szerét" (idézi
} Wessely, 2003: 17), de más „tömegmüfajt”, így az akkori jazzt sem kímélő írásaiból is bőven idézhetnénk (pl. Adorno, 1978). 
tömegkultúra differenciálatlan, emancipációs potenciállal nem rendelkező homogén sokszor elitista - elképzéseivel szakítva, a kulturális gyakorlatok ideológiai, etnikai, később társadalmi nemekkel és szexuális orientációkkal összefüggő reprezentációk kritikai olvasatát kínálták (Ritzer és Smart, 2013). Hebdige (1979) Subculture: The Meaning of Style [Szubkultúra. A stílus jelentése] címü müve jelen kutatás szempontjából annyiban fontos referencia, hogy az egyes szubkultúrák etnográfiai elemzésénél, az etnikai dimenzió mellett külön hangsúlyt fektet a közösségek tagjainak külső reprezentációira, a megjelenésre, valamint a viseletek szimbolikus jelentéstartalmaira is. ${ }^{49}$ A jazzszíntér relációinak feltérképezése során is fontos szempontként szerepel az egyes pozíciók pl. nyelvi reprezentációinak vizsgálata, ugyanis ezek a kódrendszerek a mező különböző pozíciói közti distinkciók és jelentéssel bíró kulturális gyakorlatok meghatározó aspektusai.

A '90-es évek európai kultúrakutatásának új hullámához tartozó Sarah Thornton (1995) elméleti újításairól érdemes még szót ejteni, hiszen a Club Cultures [Klubkultúrák] innovatív megközelítése alapvetően a jelen kutatás szempontjából is meghatározó bourdieui fogalmi rendszerbe illeszkedik. A mü szerzője Bourdieu tőkefogalmát (1999 [1986]) emeli át a klubkultúrák területére, hangsúlyozva a belső különbségtételrendszerek és hierarchiák (centrum-periféria viszonyok) szerepét egy adott (szub)kulturális közegben. A szubkulturális tőke fogalma a kutató pozícióját tekintve is markánsan felmerül, ahogy később kifejtem, a több mint három éve tartó kutatás során a szcéna attitüdjei, az interjút készítő belső tudása, el- és felismertsége „szubkulturális tőkéje” fontos belépési adónak bizonyult a szcénán belüli csoportokhoz.

A szcénát mint teoretikusan megalapozott koncepciót először Straw (1991) alkalmazta koncepciózus módon a társadalom- és kultúratudomány területén. ${ }^{50}$ Azóta a fogalom a populáriszene-kutatás, (kultúra)szociológia és ifjúsági kultúrával foglalkozó kutatások bevett elméleti koncepciójának számít (Bennett, 2004), melyet - Bennett és Peterson (2004) tipizálását alkalmazva - lokális, transzlokális és virtuális kontextusok széles skáláján alkalmaznak. A szcénát megelőzően a „közösség” (musical community), művészeti világ (artworld) és szubkultúra fogalmakat alkalmazták a zenei közösségek és a társadalmi élet kapcsolatainak értelmezésére (Bennett, 2004), fogalmanként más-más szempontokat

\footnotetext{
${ }^{49}$ Hebdige olyan referenciákkal tágítja a kritikai kultúrakutatás marxista, strukturalista szemléletü birminghami tradícióját, mint Eco és Barthes (lásd a kötet magyarul megjelent részletét: Hebdige (1995, [1979]).

${ }^{50}$ Shanks pl. használja a fogalmat a rock 'n' roll közösséggel kapcsolatos elemzésében (1988), melyre a fogalmat szélesebb tudományos körben megalapozó Straw is hivatkozik (1991: 373).
} 
hangsúlyozva (Frith, 1981; Weinstein, 2000). A térben viszonylag lehatárolt „in situ” gyakorlatokra fókuszáló „közösség” szaknyelvből meglehetősen kikopott fogalmával ellentétben a szcéna inkább a különböző irányzatokhoz köthető közös szimbolikus, nyelvi, kulturális és ideológiai szempontokat hangsúlyozza, eleinte lokális urbánus kontextusokban (pl. Cohen, 1991). A szcéna alapvetően egy fenomenológiai koncepció, ${ }^{51}$ mivel egy-egy zenei stílushoz tartozó széleskörü jelenségegyüttest ír le: Kik hallgatják az adott zenét? Milyen társadalmi összetételű csoportok járnak koncertekre? Van-e közös nyelvhasználat, a szcénára jellemző szleng? Milyen kulturális szokások köthetők a szcénához? Mennyire különül el az adott szcéna (és milyen szempontok mentén kapcsolódik) más zenei szcénákhoz? Van-e átfedés az egyes szcénák közt? Túl a lokális szcénákon, pl. „philadelphiai rave szcéna” (Anderson, 2009), a nemzeteken átívelő közös kulturális kódrendszert használók laza közösségeit a rajongói kultúra (fandom) ernyője fogja össze. Jóllehet a szcénakoncepció a késő modern társadalmak zenei színtereinek nemi, etnikai, politikai és társadalmi sokszínüségét adekvátan leíró fogalom, a társadalmi egyenlőtlenségekből fakadó konfliktusok hatalmi dimenzióit kevésbé veszi figyelembe (Varriale, 2014). A két koncepció közti alapvető különbség az, hogy míg a szubkultúra feltételez egy mainstream kultúrát - érvel Straw (1991) nyomán Bennett és Peterson (2004) -,mellyel szemben a szubkultúra tagjai megkülönböztetik magukat, addig a szcéna koncepciója a kollektív jelentéskonstrukció közösségalkotó szempontjait helyezi előtérbe, jellemzően mikroszociológiai és etnográfiai elemzések során.

A fenti kötet szerzőivel egyetértésben a szcénát a bourdieu-i mezőfogalommal (1993, 1996) és a Becker által meghonosított müvészeti világ (Becker, 1982) koncepciójával összeegyeztethető elméleti keretnek tekintem, mert a fogalom egy zenei stílus körüli, adott (földrajzi vagy virtuális) térben vegyes összetételü társadalmi csoportok tagjainak kulturális gyakorlataira utal, akik valamilyen módon azonosulnak a zene közvetítette kulturális kódokkal, szokásokkal, esetleg politikai-ideológiai nézetekkel (Bennett, 2004). A kutatási orientációtól függően, a budapesti jazzszíntér egy olyan globális szcéna részeként is értelmezhető, melyet a számos irányzatot és leágazást egyesítő zenei műfajhoz köthető egyének laza közössége (rajongók, közönség, jazz-zenészek, a zeneiparban dolgozó

\footnotetext{
${ }^{51}$ Wessely Anna szóbeli közlése nyomán.
} 
szakemberek, kritikusok, kiadók stb.) alkot, ${ }^{52}$ akik számára a homogénnek tekintett mainstream kultúrával szemben történő explicit meghatározottság nem kulcsfontosságú kollektív identifikációs elem. Noha a szcéna- és szubkultúra-koncepciókkal az irányzatok és müfajok köré szerveződő közösségek fontos jellemzői ragadhatók meg, a mezőkonstrukció komplexebb modellt kínál a szimbolikus különbségtételrendszerek életstílusokkal és társadalmi egyenlőtlenségekkel összefüggő reprodukciós logikájának megragadásához. Ebből kifolyólag az empirikus elemzés során a mezőelméletből, valamint az azt kvalitatív módszerrel alkalmazó kultúraszociológiai trendekből indulok ki (lásd pl. Varriale, 2015; Rimmer, 2012; Atkinson, 2011 etc.). Összefoglalva: míg a szcéna fenomenológiai koncepció, addig a „mező” analitikus konstrukció, mely a társadalmi jelenségek és kulturális gyakorlatok modellezését teszi lehetővé. A dolgozat empirikus fejezeteinek célja pedig a kortárs jazz-zenei mező hierarchizált viszonyrendszerének modellszintű megragadása.

\subsection{Müvészeti világ és mező}

Becker és Bourdieu munkásságában (számos megkerülhetetlen eltérés ellenére is) közös, hogy szociológusként mindketten a maguk módján szakítottak a mủalkotás idealizálásának, „földfelettiségének” karizmatikus ideológiájával (Grazian, 2008; Prior, 2011) - bár merőben eltérő módon és más hagyományokból kiindulva. ${ }^{53}$ Sarkosan fogalmazva, míg Bourdieu-nél (pl. Becker kritikái szerint) az individuum cselekedetei „misztikus” erőhatások mechanikus következményei, addig Beckernél kvantifikálható, kooperációra épülő kapcsolathálók eredője a műalkotás. Ahogy Prior (2011: 123) kifejti, Beckernél a kreativitást felváltja a „munka”, a müvészi inspirációt a „konvenciók” és a kollektív szakmai szabályokra épülő munkakapcsolatok. Becker (1974) a közvetítő láthatatlan személy(ek) kooperációra épülő kollektív gyakorlatait hangsúlyozza, melyek lehetővé teszik az alkotás létrejöttét. A kooperációs hálók és láncok szerepének egyik legátütőbb metaforája a hollywoodi filmipar. A kooperációra épülő összművészet gyakorlata során a művészeti érték létrehozása nem (csak) a rendezőnek köszönhető, de - mint az Becker szerint az Óz, a csodák csodája címü film készítése kapcsán kiderül - egy bizonyos döntő dramaturgiai ötlet a film zenéjéért

\footnotetext{
${ }^{52}$ A ,jazz-zenész” kifejezés konzekvens használata az értekezés során - szemben a tánczenész és „hétköznapi zenész" kifejezésekkel (Becker és Faulkner, 2009) - a vizsgált szcéna lokális jellegzetességéből is fakad (lásd 3.1. fejezet).

${ }^{53}$ Lásd Becker interjúját a mezőfogalomról (Becker és Pessin, 2006) és Bourdieu explicit kritikáját a beckeri megközelítésröl (Bourdieu, 1996: 205).
} 
felelős szakembereknek volt tulajdonítható (Becker, 1982). A müvészeti világ koncepció alapvetően interakcionista nézőpontot képvisel, és azokat a tényleges kollektív gyakorlatokat, interakciókat, kooperációs mintákat helyezi előtérbe, melyek a műalkotás (koncert, film, irodalmi alkotás stb.) konkrét létrejöttéhez szükségesek. E „prózai” megközelítésnek mindenképp elönye, hogy a fogyasztók számára többnyire láthatatlan, háttérben zajló interakciók és intézmények összefonódásaira, a műalkotás létrejötte szempontjából tevékeny apparátus szerepére és a szakmai szocializáció fontosságára felhívja a figyelmet, azonban a koncepció heurisztikus ereje ezzel ki is merül, mert a kooperatív interakciókat tartja a szociológiai elemzés tárgyának a müalkotás létrejöttének szempontjából, figyelmen kívül hagyva az erőtér „objektív” szerkezetét, amelyben az konstituálódik. A Müvészet szabályainak müvészeti világról szóló (egyetlen) passzusát hosszabban idézve:

(...) a müvészetvilág ${ }^{54}$ [kiemelések az eredetiben: H.Á.] fogalma, amely az Egyesült Államokban használatos a szociológiai es a filozófiai mezőben, egy teljesen ellentétes társadalomfilozófiából származik, mint amelyben az Írok Köztársaságának eszméje lakozik, ahogy azt Bayle bemutatja, es visszalépést jelent a mező elméletéhez képest (...). Howard S. Becker abból a feltevésből, hogy „a müalkotások az összes olyan cselekvő összehangolt tevekénységének eredményének foghatok fel, akik együttmüködése szükséges ahhoz, hogy a müalkotás az legyen, ami”, arra a következtetésre jut, hogy a vizsgalatnak mindazokra ki kell terjednie, akik hozzájárulnak ehhez az eredményhez, vagyis „azokra, akik kitaláljak a művet (...), akik kivitelezik (...), akik a szükséges anyagi eszközöket szolgáltatják (...), es akik a mü közönségét alkotják (...)”. Anélkül, hogy módszeres kifejtésébe bocsátkoznánk, mi a különbség a „műveszetvilág” látásmódja es az irodalmi vagy művészeti mező elmélete között, csak annyit jegyeznék meg, hogy az utóbbi nem redukálható egy populációra, vagyis bizonyos számú individuális ágensre, akiket egyszerü interakció, pontosabban kooperáció kapcsolna össze. Ebböl a tisztan leíró es felsoroló jellegủ taglalásból többek között azok az objektív viszonyok maradnak ki, amelyek meghatározó összetevői a mező struktúrájának, es irányítják a változatlanul tartásáért vagy átalakításáért folyó harcokat (Bourdieu, 2013: 225-226).

\footnotetext{
${ }^{54}$ Seregi a bevett használatnak megfelelő beckeri „,művészeti világot” fordítja „müvészetvilágnak”, mely Danto (1964) koncepciójára utal: Becker müvészeti világa szociológiai, Danto művészetvilága művészetfilozófiai fogalom más-más implikációkkal.
} 
Bourdieu megalapozta a posztmarxista szociológiai vizsgálódást zene és társadalom kapcsolatáról (Prior, 2011), főleg a habitus, a mezőelmélet és a kulturális tőke fogalmai révén. Beckerrel együtt a kortárs kultúra- és zeneszociológia legtöbbet idézett szerzői, mert a müalkotásokat társadalmilag meghatározott erőtérben, kapcsolathálók kontextusában értelmezik, igaz, mint említettem, meglehetősen eltérő aspektusból. Bourdieu kulturális és mủvészeti mezőkön elsősorban pozíciók strukturált tereit érti, melyekben a különböző habitusú - tudattalanul inkorporált viselkedési, gondolkodási, értékelési és érzékelési sémák rendszerével rendelkező - ágensek a szimbolikus profitok elosztásának monopolizálásáért küzdenek egymással. Amint a következőkben megpróbálom részletesebben is bemutatni, a mező olyan (gazdasági, szimbolikus és legitimációs) harcok és konfliktusok terepe, ahol a legitim művészet definíciójának megalkotása érdekében az ágensek pozíciószerzései az (1) általuk „,birtokolt” tőkekombinációkkal (gazdasági, kulturális, szimbolikus, társadalmi), (2) a mező szerkezetével (a többi pozícióval), (3) a külső, politikai és gazdasági erőtér strukturáló erejével és az osztályozható és (4) egyben osztályozó praxisokat generáló társadalmilag kondicionált habitusokkal vannak összefüggésben. ${ }^{55}$

A Bourdieu kultúraszociológiájában alapvető mezőfogalomnak (Bourdieu, 1993, 1996) olyan interpretációjával dolgoztam, amely magában foglalja az elmélet fő heurisztikus erejét adó relacionális logikát, egyúttal összeegyeztethető a szcéna fentebb kifejtett fogalmával is, mely egy zenei stílus identitás- és közösségformáló erejét hangsúlyozza (Lewis, 1992; Kahn-Harris, 2007). Ez a megközelítés egyúttal megengedő a városi szubkultúra-kutatásokra és antropológiai munkákra jellemző mikroszituációk etnográfiai sürű leírásának módszerével is. Ugyan a mezőelmélet komplex fogalmi hálójának összeegyeztethetősége a szcéna és szubkultúra fogalmaival itt bővebben nem kerül kifejtésre, megjegyzendő, hogy az említett fogalmak szintézisére a populáriszene-kutatásban és zeneszociológiában több példát is találni (Straw, 1991: 385; Kahn-Harris, 2007; Kacsuk, $2015) .{ }^{56}$

55 Ez az általam felsorolt négy szempont esetleges, természetesen minél inkább beássuk magunkat a meződinamika alapelveibe (Bourdieu 1993; 1996) különböző, pozíciószerzéseket meghatározó strukturáló erővel bíró szempontokat definiálhatunk (a mező történetét, a „pénz és müvészet” oppozícióját, a generációk szerpét, strukturális homológiákat, az egyes almezők differenciálódását stb.).

${ }^{56}$ Lásd pl. Kahn-Harris extrém metálról írt monográfiájának „A szcéna és habitus” (The Scene and Habitus) címü alfejezetét (Kahn-Harris, 2007: 70) vagy Straw (1991: 385) megengedő attitüdjét a mező- és szcénakoncepció alkalmazását illetően. 


\subsection{A mezőelmélet ${ }^{57}$}

\subsubsection{A mezökonstrukció modelljének váza}

A kutatás megvalósítását- operacionalizálási eljárásait, episztemológiai alapvetéseit, a szociológiai tárgy- és témakonstrukciót stb. - alapvetően meghatározó mezőkonstrukció modelljének bemutatása, gondolhatnánk, az egyik leginkább - zenei zsargonnal élve „kézben lévő” szegmense a doktori értekezésnek. Azonban ez koránt sincs így; a megközelítés sajátosságát tekintve sem jelentéktelen adalék, hogy az empirikus elemzés(eke)t követően futok neki annak a fejezetnek, amit a könyvtárnyi Bourdieu-t interpretáló (őt méltató, tagadó, ,szociológiai terroristának” bélyegző, árnyaló, esetleg az általa képviselt reflexív praxist „gyenge programként” értékelő stb.) kiterjedt szakirodalom ismerete alapján könnyüszerrel meg lehetne írni. A fejezet „munka végére hagyása” részint abból a meggyőződésemből fakad, hogy bármily átfogó leírását is adná a mezőelemzés absztrakt alapelveinek egy szerző, az egyáltalán nem volna elégséges feltétele a különböző szociológiai hagyományokat „egymás ellen kijátszó” (Wessely, 2005: 224) és szintetizáló, a konstruktivista strukturalizmus skolasztikus kategóriájába sorolt paradigma, vagy, „konceptuális építmény” ihlette érvényes és izgalmas empirikus elemzések létrehozásához.

A bourdieu-i szociológia „elméletalkotást, az empirikus kutatást és a statisztikai elemzést minden lépésben metodológiai reflexióval ötvözö" (Wessely, 2005: 218) munkamódszeréből azon szempontokat igyekszem hangsúlyozni, melyek a kvalitatív kutatásom módszerére vonatkozóan alapvető fontosságúak voltak. Tehát inkább pragmatikus-összegző alfejezet írása mellett döntöttem, ahelyett, hogy a különböző szociológiai (durkheim-i, Weberiánus, strukturalista, marxista, fenomenológiai, stb.) irányzatok szintézisére építő bourdieu-i konstruktivista strukturalizmus részletes rekonstruálását tüztem volna ki célul a bourdieu-i életmű kontextusában. ${ }^{58}$

\footnotetext{
57 A disszertáció kereteit meghaladná a mezőelmélet kritikai recepciójának részletes bemutatása. A mezőelméletet érintő kultúraszociológiai diskurzusok, így a Bourdieu kultúraszociológiáját „gyenge programként” aposztrofáló (Alexander és Smith, 2002) és az állításait kritikai szempontból interpretáló Gartman (2007) évrendszere sem kerül itt részletes bemutatásra. Ehelyett a kutatás legfontosabb elméleti hátteréül szolgáló mezőelmélet müvészetszociológiai alkalmazásának kimerítő bemutatása a cél.

${ }^{58}$ Az életmű szempontjából jelentős paradigmák, mérföldkövek és művek általam ismert két leginkább átfogó magyar nyelvű összegzéseit lásd Hadasnál (2001) és Wesselynél (2005), melyek a bourdieu-i szociológiába való egyfajta „bevezetésként” is értelmezhetők. Továbbá a Language and Symbolic Power (1991) [Nyelv és szimbolikus hatalom] és a The Field of Cultural Production [A kulturális termelés mezője] hosszabb
} 
A bourdieu-i szociológiát általánosságban szokás a szociológia tudományát születésétől fogva végigkísérő dualizmusok (pl. individuum és kollektíva, szubjektív és objektív, az állandó és a változás stb.) meghaladására tett kísérletnek is értékelni (Thompson, 1991). A mezőelmélet vázát sematikusan összefoglaló fejezetben először Bourdieu cselekvéselméletében alapvető fontosságú habitusfogalom kifejtésével kezdem, mely a strukturalista determinizmus és a teleologikus-instrumentalista racionális cselekvés elméletének episztemológiai ellentéteit igyekszik meghaladni. A strukturalizmus ahistorikus (történeti változásra érzéketlen) szemléletének meghaladása arra utal, hogy a cselekvés nem levezethető objektív strukturális kényszerekböl, e mellett Bourdieu a racionális döntéselmélettel szembeni határozott fellépése ${ }^{59}$ során a haszonmaximalizálást mint praxisokat generáló egyetlen alapelv ökonomista szemléletét is kritizálja (Hadas, 2001). Panofsky (1986) művének, „Gótikus épitészet és a skolasztikus gondolkodás” fordításakor érik meg benne az Arisztotelészig visszanyúló habitusfogalom szociológiai megfogalmazása. Bourdieu társadalmi praxeológiájában a cselekvések kontextuálisan meghatározott, improvizatív és intencionális, a ,játékérzethez” hasonlítható dimenziói kifejezetten hangsúlyosan vannak jelen:

A habitus az észlelési, gondolkodási, cselekvési és értékelő sémáknak a családi, az iskolai, a szakmai stb. szocializációban elsajátított tudattalan rendszere, a megfigyelhető gyakorlat és a mögötte rejtező vagy benne kifejeződő kollektív struktúrák közötti összefüggés megteremtője (Wessely, 2005: 224).

A fenti, sürü definíció minden eleme fontos. Tudattalanul elsajátított (inkorporált) tartós diszpozíciók rendszeréről van szó, amely az improvizatív igazodások logikáját követő cselekvések (praxisok) generáló elve. Az egyes mezőkben való cselekvések értelmezhetők a sport, illetve a játék analógiájára: a játék hevében nincs idő pontos számításokat végezni, a cselekvő azt teszi, ami a többi pozíciót betöltő ágenssel alkotott viszonyrendszere, valamint felhalmozott tőkéje alapján leginkább optimális számára. Mivel az elmélet egy társadalmi praxeológia részét képezi (Bourdieu, 1977), a habitus a(z) (egyéni) gyakorlatok, valamint a bennük kifejeződő kollektív struktúrák között közvetít. Vagyis, a habitus

szerkesztői előszavai (Thompson, 1991; Johnson, 1993) is átfogóan mutatják be a bourdieu-i szociológia fogalmi hálójának legfontosabb fogalmait és elméleteit (mező, habitus, tőkekonverziók stb.).

${ }^{59}$ Lásd pl. a magyarul is olvasható „Gazdasági tőke, kulturális tőke, társadalmi tőke” címet viselő cikkét, melyben az ún. „human capital” elméleteket kritizálja, többízben kihangsúlyozva, hogy a cselekvés (pl. pályaválasztás) nem magyarázható puszta haszonmaximalizálásból kiinduló teleologikus cselekvésekkel. 
„strukturált, strukturáló, struktúra” (Bourdieu, 1984). Strukturált struktúra, mert a társadalom strukturális viszonyait, a tőkeeloszlások struktúráját jeleníti meg, ugyanakkor a relacionális térben a társadalmi struktúra által kondicionált habitus a társadalmat is alakítja, ezért egyúttal strukturáló struktúra is. Egy korábban illegitim cselekvési mód kiharcolhatja magának, hogy idővel legitim cselekvési módként tételezzék a mező pozícióit elfoglaló ágensek. Ezzel azonban a mező korábbi koordinátáit is átírják, következésképpen a lehetőségek tere is megváltozik, amelyhez - a ,játék analógiájára" - improvizatív módon igazodik a mezőt alkotó többi ágens. Ettől válik dinamikussá a relacionálisan konstituált társadalmi univerzum, amit Bourdieu mezőként definiál.

Bourdieu értelmezésében a modern társadalmak differenciált társadalmi tevékenységek körül létrehozott relatív autonómiával bíró mezők viszonyrendszerében ragadhatók meg. A pozíciók megszerzéséért és megtartásáért folytatott küzdelmek csatateréül szolgáló viszonylag önszabályozó (Wessely, 2012) eröteret a pozíciók olyan „objektív viszonyok hálózata” alkotja (Bourdieu és Wacquant 1992: 97), amely megfelel azon tőkeeloszlások struktúrájának, melyek által a mezőben sikert lehet elérni. Alapvető továbbá, hogy a mezők mindig valamilyen specializált szaktudás szerint jönnek létre, és e tudás legitimációja érdekében harcok folynak rivális csoportok között. A mezőként definiált társadalmi mikrokozmoszt, legyen az a vallás, a művészet vagy a tudomány, az adott (mủvészeti, tudományos stb.) cselekvés legitim definíciójának monopolizálásáért folytatott harcok jellemzik. Az irodalmi mező müködését és struktúráját pl. az író legitim definíciójáért folytatatott harcok kontextusában értelmezhetjük a mezőlogika alapján. A sajátos szabályrendszerrel rendelkező differenciált társadalmi univerzumok alatt tehát az uralkodó hatalmi viszonyok megváltoztatására vagy megőrzésére, konzerválására irányuló küzdelmek történetileg kondicionált ${ }^{60}$ strukturált tereit értjük. A domináns pozíciók (mely lehet egy intézmény, pl. az Akadémia, vagy akár egy egyén is, pl. Baudelaire a 19. század második felében) a monopóliumuk megtartására, újratermelésére törekednek, míg az újonnan jövő „eretnek” generáció e hatalmi pozíciók megdöntésére és betöltésére, vagy új pozíciók megteremtésére törekszik (Hadas, 2001; Hilgers és Mangez, 2014; Maanen, 2009). Ahhoz, hogy valaki egyes mezőkben részt vegyen a játékban, szükség van mezőspecifikus

\footnotetext{
${ }^{60} \mathrm{~A}$ strukturalista doxa ahistorikus szemléletével szemben Bourdieu a mezök történeti meghatározottságát hangsúlyozza, vagyis a jelenségeket kialakulásuk története alakítja (Bourdieu, 1996; Bennett, 2005). A korábban hivatkozott mü, $A$ müvészet szabályainak alcíme is ezt hivatott alátámasztani: „Az irodalmi mező genezise és struktúrája".
} 
kompetenciák (referenciák, tipikusan vezéralakokkal fémjelezte „izmusokban” való jártasság, tanulás során elsajátított szaktudás, vagy titulusok stb.) elsajátítására, belépési dijra, vagy ,adóra” (droit d'entrée) ,amit az egyének többnyire (legalább felsőfokú) képzésük költségeinek formájában rónak le" (Wessely, 2012: 67). A mezőben hatások kiváltásához elengedhetetlen, hogy a cselekvőket a domináns pozíciókat betöltők felismerjék: azzal, hogy a domináns autoritások az ellenük küzdő eretnek „fiatalokat” támadják, egyúttal a felismertséggel járó legitimációt is biztosítják a „parvenü” csoportok számára. Míg a vallási mezőben például a vallási javakért, vagy, ahogy Bourdieu a weberi vallásszociológiából átveszi, az „üdvjavak” monopolizálásért folyik a harc (Bourdieu, 1991b), addig egy új ,,izmus” kialakulása az irodalomban, vagy a képzőmüvészetben is jól megragadható a mezőelmélettel (Hadas, 2001), hiszen azokat a küzdelmeket hangsúlyozza, amelyek során egy intézményesült pozícióval szemben fellépők, a szabályok, tétek megváltoztatását követelik.

Egy adott korszak esztétikai hierarchiájának müvészetszociológiai elemzéséhez elengedhetetlen szempont a müalkotások szimbolikus és anyagi termelöinek megkülönböztetése, hiszen a müalkotás akkor létezik, ha vannak, akik felismerik és értéket tulajdonítanak neki (Bourdieu, 1993). Az esztétikai hierarchia - müvészeti ágakon belül és művészeti ágak között - a szimbolikus és anyagi profitok elosztásáért vívott harcok során alakul ki, az akadémia és intézményes felszentelés, az újságok, kritikusok szimbolikus szankciói és a piac személytelen mechanizmusainak dimenzióiban. Továbbá, szakítva a müvészettörténet szerinte hagiografikus hagyományával, az egyes erőterek cselekvőit az összes többi cselekvővel alkotott viszonyában értelmezi, mert a müalkotás teremtőjét és az általa létrehozott műalkotást a mezőt alkotó relációi kreálják. A kánonalkotás bourdieu-i művészetszociológiája úgy leplezi le a teremtetlen teremtő romantizált, idealista képét, hogy a másod- és harmadrangú alkotók viszonyrendszerében értelmezi a műalkotások létrejöttét. A bourdieu-i művészetszociológiai elemzés sajátossága tehát abban rejlik, hogy a műalkotás értékébe vetett hit termelőit, a legitimitást biztosító felszentelő apparátusokat, és a mezőt alkotó pozíciók közti viszonyokat is figyelembe veszi elemzése során, ami nála tudatos módszertani elemként van jelen (Bourdieu, 1993). Ehhez kapcsolódik Bourdieu további fontos megfigyelése, mely szerint egy művészeti mező kialakulása együtt jár az „anómia intézményesedésével", ami azt jelenti, hogy a művészet legitim definíciójának monopolizálásáért küzdő ágensek közül - hosszú távon legalábbis - senki sem gyakorol abszolút hatalmat a szimbolikus profitok elosztása fölött (Bourdieu, 1996: 132). A mező történeti dinamizmusát a tradíció ellen való lázadás tradíciójának dinamizmusa adja, mely 
az erőviszonyok történeti perspektívából történő változására utal, melynek logikáját a Kulturális termelés mezője címü müben is lefektetett alapelvekkel ragadhatjuk meg. Bourdieu arra a történeti folyamatra utal, amely során a fiatalabb, akadémiai (,polgári”) legitimációval nem bíró, jellemzően kevesebb gazdasági tőkét birtokló generáció idővel megdönti a konzervatív ortodoxiát képviselő, saját mủvészet- vagy tudománydefiníciójukat ahistorikus módon univerzálisnak feltüntető előző generáció monopolpozícióit: vagyis, az újonnan jövők, ahogy írja, a „doxát dogmává alakitják” (Bourdieu, 1996: 185).

A müvészet mezőelméleten keresztül való értelmezése azt jelenti, hogy minden egyes müalkotást az egész mezőt átszövő viszonyok manifesztációjának tekintünk. Magában a müalkotásban „sajátos módon koncentrálódnak a mezőben ható erők és szabályok” (Bourdieu, 1996: 37), így a müalkotás létrejötte a mezőben uralkodó szabályok szükségszerü következménye. Kissé sarkítva, míg a Kulturális termelés mezöjében (Bourdieu, 1993) a bőséges empirikus történeti példák, a mezőelmélet szofisztikált fogalmi apparátusának gyakorlati jelentőségét illusztrálják, addig a Müvészet szabályaiban (1996 [1992]) a szerző szisztematikusan elemzi francia irodalmi mező létrejöttét (,genezisét és struktúráját”) a hosszú 19. század utolsó harmadában. Egy szofisztikált történeti-szociológiai elemzésnél azonban többről van szó, mivel a Müvészet szabályai, a mezőelméletből kiinduló művészetszociológia - meggyőződésem szerint - „erős programját” is paradigmatikus igénnyel hirdeti, ${ }^{61}$ melyet tudatos ,,paradigmaexpanzióként” hajt végre például a társadalmi nemek területén (Hadas, 2015). ${ }^{62}$

Bourdieu művészetszociológiájában a kulturális termelés mezőjét szervező két legfontosabb ideáltipikus alapelv a heteronómia és autonómia elvei, vagy egyszerúen ahogy egy alfejezet címe is jelzi a Müvészet szabályaiban - a „művészet és pénz” ellentétének strukturáló ereje. A heteronómia alapelve azt jósolja, hogy a müvészeti mező eltünne, ha kizárólag külső, gazdasági és politikai hatásoknak lenne kitéve. Ha a mező csak piaci hatásoknak lenne alárendelve, a „müalkotás” eme szélsőséges esetben elvesztené esztétikai értékét, feloldódna a kommerszben, vagyis a társadalmilag kondicionált észlelési, gondolkodási és értékelési sémák (diszpozíciók) helyébe a piacon vagy a politika szférájában

\footnotetext{
${ }^{61}$ Lásd pl. „Alapelvek a kulturális alkotások szociológiájához” (Bourdieu, 1998a) c. magyarul is elérhető tanulmányát, illetve Bourdieu (1996), különösen (Bourdieu, 1996: 177-209).

${ }^{62}$ A nyelv területén pedig a Language and Symbolic Power címü munkájában (Bourdieu, 1991) alkalmazza a habitus és mező fogalmait. E munkában - meglátásom szerint - „,vegytiszta” módon érhető tetten Bourdieu tudományos stratégiája, amennyiben a különböző szerzők (pl. Chomsky és Habermas) elméleteit interpretálja és kritizálja a nyelv hatalmi relációkban betöltött funkciója kapcsán.
} 
elért gazdasági siker lépne. Ezért kulcsfogalom Bourdieu művészetszociológiájában a mezö autonómiafoka (vagy a mezőhatárok kodifikáltságának szintje), ugyanis a történeti fejlődés következtében almezők szerint differenciálódó kulturális termelés mezőjében, a különböző művészeti ágak a piacnak való direkt alávetettség és a kizárólag a termelök számára történő tiszta termelés pólusai közt feszülő strukturált térben helyezkednek el.

Müvészeti mezőről akkor beszélhetünk, ha létezik egy külső, gazdasági és politikai hatásoktól valamelyest önálló, saját szabályoknak és esztétikai kritériumoknak alárendelt erőtér, ahol vannak olyan müvészek, akik csak azok értékítéletét fogadják el, akiket maguk is értékelnek (Bourdieu, 1993). ${ }^{63}$ Minél inkább képes felfüggeszteni, vagy megfordítani a domináns hierarchizálódás elvet, annál inkább teljesíti be saját autonómiáját mint „mező” (Bourdieu, 1993). Ezt hívja Bourdieu a kulturális hierarchizálódás autonóm alapelvének (autonomous principle of hierarchization), amely szerint a müalkotások és stílusok közti hierarchiát a müfaj szerinti szimbolikus elismerés, vagy presztízs kondicionálja, ami az által keletkezik, hogy müértők, kritikusok, müvészek, galériatulajdonosok, producerek stb. elismerik és értékelik a műalkotásokat a „szimbolikus javak piacán”. A mező határát és autonómiafokát tehát a két „tiszta” szélsőséges eset; a piaci nyomásnak és közízlésnek teljes mértékben kitett, kommerszben feloldódó „kulturális termék” tömegtermelése (large-scalepruduction), és a csak a müértők által fogyasztott és értékelt műalkotások korlátozott termelése (restricted production) jelöli ki, mely történeti perspektívából a münemek közti legitimitás- és presztízskülönbségeknél is fontosabb strukturáló erővel bír:

(...) A münemek közötti ellentét veszít strukturáló erejéből az egyes almezőkben jelenlévő két szélső pólus közötti ellentéttel szemben: létezik a tiszta termelés pólusa, amelyen az alkotóknak egyre inkább csak a többi alkotó a vevőjük (...) és létezik a nagytermelés pólusa, amely a nagyközönség elvárásainak van alárendelve (Bourdieu, 2013: 141).

\footnotetext{
${ }^{63}$ A következő idézet a Müvészet szabályaiból, amely Baudelaire úttörő szerepét tárgyalja az irodalmi mező létrejöttében, jól szemlélteti a fentieket (Bourdieu, 1996: 65): „1861-ben a Romlás virágainak második kiadását mind a sajtó, mind a közönség közönnyel fogadja, de irodalmi körökben a szerzöjét megalapozza, ahol még mindig számos ellensége van. (...) Baudelaire az avantgárd legszélsöségesebb pozicióját testesiti meg, amely fellázad minden, elsősorban irodalmi tekintély és intézménnyel szemben" (forditás angolból a sajátom: H.Á).
} 
A mezőspecifikus tőkékkel rendelkezők által érvényesített domináns művészetdefiníció (autonómia alapelve) tehát nem automatikusan (értsd: rövid távon) vonja magával a tömeges sikert, ${ }^{64}$ sőt, a piaci logika felforgatásával törtneti genezisét tekintve egy zéróösszegü játszmává alakul a pénz és művészet világában való érvényesülés (lásd pl. Baudelaire szerepét a francia irodalmi mező kialakulásában). Modelljében Bourdieu a korlátozott és a tömeges termelés mezőjét is a fogyasztók és termelök társadalmi helyzetével, az általuk birtokolt erőforrásokkal (tőkekombinációkkal) strukturálisan homológ almezők szerint differenciálja. A tömegtermelés (vagy Seregi fordításában „nagytermelés”) mezője - a korlátozott termelés mezőjének szerkezetével is homológ módon - a polgári („,burzsoá”) és a kommerciális (,populáris”) művészet almezői szerint differenciálódik:

(...) azok a szerzők, akiknek sikerül biztosítaniuk maguknak a világi sikert és a polgári elismerést is (az akadémiait), társadalmi származásukban es életútjukban, illetve életmódjukban és irodalmi hajlamaikban is különböznek azoktól, akik az úgynevezett populáris sikerre vannak ítélve, mint például a népies regények szerzői, a bohózatírok vagy a chanson-szerzők (Bourdieu, 2013 [1992]: 242).

A „tiszta termelés”, vagy a hierarchizálódás autonóm alapelve alapján meghatározott korlátozott termelés mezőjében pedig különbséget tesz két eltérő termelési mód strukturálta almező, a felszentelt avantgárd és újonnan jövő „eretnek” avantgárdok között, akik az „eretnekség modelljét követve, akár egy régi legitimációs elvhez való visszatéres nevében” (Bourdieu, 2013 [1992]: 241) kétségbe vonják a „felszentelt avantgárd” érvényét. Sarkítva, Bourdieu modelljében alapvetően három, a fenti alapelvek szerint strukturált „piacot” különíthetünk el: a tiszta termelés piacát, a tömegtermelést és a közepes legitimitású kulturális termelési mezőt.

\subsubsection{A korlátozott termelés és a tömegtermelés közti kapcsolatok}

Bourdieu a Kulturális termelés mezőjében is külön fejezetet szentel a két hierarchizálódási alapelv kapcsolatának (Bourdieu, 1993: 125), melyben külön hangsúlyozza a kulturális

\footnotetext{
64 Bourdieu szerint a történelemtudomány reflektálatlanul az autonómia alapelvét fogadja el domináns kultúradefiníciónak, amikor a piacnak termelő, később feledésbe vesző művészeket sok esetben nem tart számon, noha a művészetszociológiai elemzés lényege pont az volna, hogy a többi „termelő” relációjában vizsgálja az „idő próbáját kiálló” legitimnek tételezett müalkotások létrejöttét (Bourdieu, 1993).
} 
alkotások elemzésének módszertani megfontolásait is. Az egyik fontos elem a legitimációt biztosító, felszentelő intézményeket egyesítő relációk elemzése. A közepes legitimitású müvészetet (l'art moyen $)^{65}$ Bourdieu a tömeges termeléshez sorolja, amennyiben a kulturális alkotásokat teljesen a fogyasztók, a közönség igényei definiálják: a munkák termelésének elvét a lehető legszélesebb közönség elérése jelenti. Az idesorolt termelési gyakorlat a közönség „kulturális és társadalmi összetételének általánosítására” törekszik (Bourdieu, 1993: 127), akkor is, ha különböző fogyasztói szegmenseket (fiatalokat, férfiakat, nőket, sportolókat stb.) céloz. A tömegtermelés és korlátozott termelés tiszta pólusai szerint strukturált kulturális termelés mezője átfogja a kortársaknak szóló avantgárd müveket, a felszentelés „útján lévő” avantgárd munkákat, a domináns osztály nem-értelmiségi frakcióinak szánt „,polgári” művészet alkotásait, a közepes legitimitású (pl. fotó), a kispolgárság (pl. operett) és a piacnak leginkább kiszolgáltatott tömegkultúrát, ami a „társadalmilag semlegesített alkotások összessége” (Bourdieu, 1993: 127).

A közepes legitimitású művészet, amely kipróbált és alátámasztott technikákra támaszkodik, sajátos viszonyban van a tiszta müvészet pólusával: a gazdasági és politikai hatalom szimbolikus újratermelése mellett a művész mentesülhet a komoly, politikai és gazdasági ügyekben való véleménynyilvánítás alól:

A „művészet a művészetért” és a közepes legitimitású [middle brow] művészet közt feszülő oppozíciónak, mely az ideológiai síkon a müvészet iránti elköteleződés idealizmusa és a piacnak való alárendelődés cinizmusa közti ellentétté alakul, nem kellene elfednie a tényt, hogy a hatalom és pénz kiváltságosainak sajátos kulturális legitimitásának ellenzése csak annak elismerésének még egy útját jelenti, hogy az üzlet az üzlet (Bourdieu, 1993: 128) ${ }^{66}$

\footnotetext{
65 Az angolban „middle brow art-nak” fordított art moyen-t, mely „közepes” és ,átlagost”, de főnévként „eszközt” is jelent, Bourdieu különböző kontextusokban használja. Az értekezés során a kifejezést - jobb híján - közepes legitimitású vagy közepes legitimitással bíró müvészetnek fordítom, mert a középosztályok müvészeti és fogyasztói gyakorlatáról van szó, szemben a nagypolgárság kultúrájával. Alternatívaként felmerültek még a „középfajú”, „középosztályos”, „könnyen hozzáférhető” kultúra és „midcult” koncepciók is. A „középfajú” kifejezést - a tragédia és komédia közé eső - színpadi müfajként szokás említeni, a „középosztályos” jelző túlhangsúlyozza a társadalmi osztályt, amely termeli és fogyasztja az ide sorolt alkotásokat, a „könnyen hozzáférhető” - meglátásom szerint - nem elég árnyalt megfogalmazás (kiknek könnyen hozzáférhető? Mi definiálja a „hozzáférést”? stb.), a „midcult” pedig „minősítés és nem osztályozás” - az utóbbi megjegyzést Wessely Anna szóbeli közlése nyomán rögzítettem.

${ }^{66}$ A magyar fordítás az angolból sajátom - H.Á:,,The opposition between art for art's sake and middle-brow art which, on the ideological plane, becomes transformed into an opposition between the idealism of devotion
} 
A mezőelméletet átható politikai gazdaságtani szemlélet az, amiért Bourdieu-t tekinthetjük a „művészet közgazdászának,” aki a materiális erőforrásokon túl a javak szimbolikus termelését, a termelésben résztvevők valóságkonstrukcióit és a történetiséget relacionális episztemológiával igekszik megragadni, anélkül, hogy egyfelől a történeti redukcionizmus, másfelöl a strukturalista ahistorizmus csapdájába esne. A különböző (gazdasági, kulturális, szimbolikus, társadalmi) tőkék konverziójának gazdasági szemlélete a hosszú távú történeti átalakulások perspektívájából is tetten érhető Bourdieu modelljében: a rövid távú anyagi veszteségek, mely a tiszta termelés strukturálisan kondicionált feltétele, hosszú távon gazdasági sikerré konvertálhatók. Bourdieu az öregedés biológiai és művészeti módjait is megkülönbözteti jellemzően szociológiai nézőpontból, pl. mikor különböző műfajú könyvek eladási statisztikáit elemzi, empirikusan is megragadva az eltérő kulturális legitimitással bíró alkotások gazdasági dimenzióját (megtérülését).

Bourdieu elismeri, hogy az alapvetően „,heteronóm”, közepes legitimitású kultúra arra van ítélve, hogy a legitim kultúrával való „objektív” viszonyban határozza meg magát, továbbá „képtelen megújítani technikáit és témáit a magaskultúrához való fordulás nélkül” (Bourdieu, 1993: 129). A „szent” és „profán” (művészet és pénz, autonómia és heteronómia, „tiszta termelés” és tömeges termelés, nemes és vulgáris, népszerü/szórakoztató és intellektuális stb. ${ }^{67}$ oppozíciója a kulturális termelés mezőjének három alapvető piaca közötti viszony szerkezetének meghatározásán túl azt is befolyásolja, hogy a legitimitáshiearchia különböző szintjein elhelyezkedő kulturális (al)mezőkön belül az alkotók hogyan hierarchizálják saját maguk és mások munkáját. Minél inkább távolabbra kerül a mủvészek egy csoportja a legitim mủvészet birodalmától, annál inkább hangoztatják érdemeiket mint technikailag képzett szórakoztatóipari szakemberek, szemben az „intellektuális” müvészet (szerintük) zavaros kísérletezésivel. Bourdieu szerint a szilárd legitimációval nem bíró, valahol a „nemes” és vulgáris” között lévő közepes legitimitású kulturális gyakorlatok - mint pl. a fotózás - folyamatosan szembesíti a részvevőit saját legitimációjuk kérdésével. A felszentelő intézményekkel, kifejezetten az oktatással

to art and the cynicism of submission to the market, should not hide the fact that the desire to oppose a specifically cultural legitimacy to the prerogatives of power and money constitutes one more way of recognizing that business is business."

${ }^{67}$ Bourdieu művészetszociológiai írásaiban a „művészet és pénz” ellentétére a fenti szinonimákat is használja. A zárójeles megjegyzést ez indokolja. 
szembeni lázadásukban tulajdonképpen saját kirekesztettségük érhető tetten, ami nem összetévesztendő az egyes kulturális (al)mezők autonóm pólusait betöltő újonnan jövő (és nem felszentelt!) avantgárd művészek akadémiai ortodoxiával szembeni fellépésével.

\subsubsection{A mainstream és free jazz termelési módjai közötti relációk}

A termelési módok strukturálta almezők kapcsolatáról szóló fejezetet olvasva lehetőség nyílik azt összeolvasni a kortárs jazzszcéna rétegződését meghatározó tényezőkkel a heteronomóm (piaci) és „tiszta” termelés közti viszonyok szemszögéből. A mainstream és free jazz pólusok oppozíciója által strukturált, a zenei mezőben relatív autonómiával bíró jazz magyar kulturális mezőben betöltött pozíciójának megragadása során fontosnak tartom a közepes legitimitású és hibrid jelzők hangsúlyozását. A kulturális felszentelés határán lévő (a populáris kultúrából és a magas legitimitású mủvészeti gyakorlatokból egyaránt merítő) jazz Magyarországon ugyan jelen van a magas kulturális legitimációt biztosító intézményekben, és magas állami kitüntetések formájában is elismerik a müfaj képviselöit, a klasszikus zenéhez való viszonyát tekintve azonban páriastátusszal bír. Már nem „szórakoztat” tömegeket - a beat korszak vokális zenéinek előretörése óta erre nem sok esély kínálkozott (lásd pl. Havas és Ser, 2017; Havadi, 2011, 2017) -, ugyanakkor felszentelt kulturális gyakorlatnak sem tekinthető a (kortárs) klasszikus zene, Kurtág, Ligeti, vagy akár az Eötvös-darabok elismertségének és presztízsének szemszögéböl.

A Zeneakadémia intézményi korpuszában elfoglalt alárendelt pozíciója a Köztelek utcai Jazz Tanszék és a felújított Liszt Ferenc téri épület kontrasztjában meglehetősen látványosan objektiválódik, továbbá a jazz, a klasszikus és a népzenei tanszakok közti forráselosztás, valamint az infrastruktúra szempontjából is „szegény rokonoknak” tekinthetők a kulturális intézményrendszer berkein belül. ${ }^{68} \mathrm{~A}$ jazz erőterén belüli distinkciók szempontjából viszont - és az empirikus fejezetek során erre fókuszálok - felfedezhetünk két termelési módot, melynek struktúrájára és müködésére nem a pénz és müvészet oppozíciója van legnagyobb hatással, hanem a különböző legitimitásokra épülő ki- és elsajátítási gyakorlatok, melyek során immár félévszázados távlatban termelödik újra a free/mainstream különbségtétel.

\footnotetext{
${ }^{68}$ A Nemzeti Kulturális Alap által kiírt pályázatoknál a jazzt (a világzenével együtt) rendre a könnyüzenei kategóriába sorolják. Jellemzően az NKA Könnyűzene Kollégiuma ír ki olyan pályázatokat, melyre jazzzenészek pályázhatnak, ami - az értekezés során nem elemzett nemzetközi és magyar kritikai recepción túl jól szemlélteti a jazz státuszát a kulturális és zenei intézményrendszeren belül.
} 
Ha a Kulturális termelés mezőjében részletezett bourdieu-i mezőkonstrukció logikája felöl nézzük a jazz müfaján belüli termelési módok közti különbségeket, akkor a mainstream jazz volna az intézményes felszentelés legitimációjával rendelkező (Akadémia, díjak) almező, míg a free jazzt játszók - akik közül sokan kritizálják a felszentelő apparátusként funkcionáló Zak-ot annak mainstream paradigmaelfogultsága miatt - lennének az eretnek, újonnan jövők, akik a mainstream ortodox hatalmát az „,autonóm művészet” nevében ásnák alá. A(z) (zene)akadémiai ortodoxia legfőbb ellenzői mellett, egyben ők alkotnák a piacnak legkevésbé kitett, vagyis leginkább autonóm csoportot, amely legitimációs harcok során új pozíciókat teremt meg, vagy (idővel) elfoglalja a mező domináns pozícióit. A helyzet nem egészen így fest, noha elmondható, hogy a mainstream jazz zenei struktúráját tekintve ${ }^{69}$ valóban befogadhatóbb a konvencionális populáris stílusokon vagy rádiózenén „edződött” fülnek, mely még (tudat alatt) fel-felismeri a musicalek világának dallamait a jazz sztenderdek $^{70}$ témáin, jellemzően a kevésbé modern kompozícióknál.

A jazz-zenei mező két eltérő termelési módjának sajátosságai nemcsak az előállított művészi produktum zenei jellemzőinek elemzése révén, hanem a zenét fogyasztó társadalmi csoport, vagyis a közönség társadalmi összetétele alapján is vizsgálhatók. A muzikológia textusközpontú megközelítése szempontjából a free és mainstream jazz közti talán legfontosabb különbség abban keresendő, hogy a free jazz értő befogadásához és értékeléséhez a mainstreamjazz-esztétika szempontjain kívül társadalmi és ideológiai referenciák elsajátítása is szükséges. A befogadó közönség szempontjából, a „free zenészek” a jazz-zenei mezőn belül is egy szükebb - a mainstream közönségénél jóval homogénebb (mủvész) értelmiségi - rétegnek játszanak. Az átjárások ellenére sincs szinte semmilyen interakció a free és mainstream csoportok vagy „táborok” között, amelyek játszóhelyek szerint is elkülönülnek egymástól. (Csak néhány zenészt sorolnak az irányzatok közt „átjáró” művészek közé: Dresch Mihályt, Oláh Kálmánt és Ávéd Jánost.) A mainstream/free distinkció történeti kialakulásának szempontjából - nagyjából a '70-es évektől - állandósult ez a struktúra. A két tábor számára mintaként szolgáló - társadalmi háttér, a városi tér

${ }^{69}$ A jazz sztenderdekben pl. vannak „témák”, dallamok, valamint a tempótartás alapfeltétel, a sztenderdek meghatározott váltakozó részekre oszthatók („A-rész”, „B-rész” stb.), és a strukturális egységek ismétlődése jellemzi az ide sorolható kompozíciókat.

${ }^{70}$ A sztenderdek alatt már megkomponált harmóniaköröket értek, melyek a jazz-zenészek repertoárját képezik, és amelyeket a közönség is sokszor (fel)ismer. Ez utóbbi nem csoda, hisz számos sztenderddé lett kompozíció (pl. All the things you are, Autumn leaves, Fly me to the moon, Juts friends stb.) korábban popsláger vagy musicalszám volt. 
szimbolikájában való elhelyezkedés és a zenei referenciák tekintetében is más minőséget megtestesítő - első generációs profetikus alakok ${ }^{71}$ már jórészt meghaltak, azonban a különbségtételek rendszere újratermelődik a jazz-zenei mező mainstream és free jazz pólusai között. A '70-es éveket követő évtizedek során a Parnasszusról nem taszították le a mainstream zenészeket az újonnan jövő „eretnek”, „kulturális felszentelés útján” lévő avantgárd zenészek. A szimultán esztétikai hierarchia koncepciója ezt a relációt igyekszik megragadni, nem eltagadva a meződinamika alapelveinek érvényességét, inkább kihasználva annak magyarázó erejét a kortárs jazz kontextusában. A következő alfejezetben a müvészeti praxis szempontjából sajátos termelési módokként leírt mainstream/free különbségtételt a közönség szempontjából, pontosabban a befogadás módjai felöl közelítem meg, reflektálva a legitimációt kölcsönző és a mezőben tőkeként funkcionáló zenei referenciákkal összefüggő termelési módok és a befogadás modalitásai közti strukturális homológiákra.

\subsubsection{A közönségröl}

A jazzben a „szent” és ,,profán” kettőssége sajátos módon van jelen: egyrészt - főként a mainstream póluson - a techné identitásképző szerepe különösen fontos, egyúttal a szórakoztató „tánczenész” toposzától is elitista módon távolságot tartanak, melyet sokszor „arisztokratikusnak” értékelnek maguk a mainstream zenészek is (pl. egyesek háta mögötti „grófúr” megszólítás eröteljesen erre utal). A jazz a magaskultúrán innen, de a közepes legitimitású kultúrán már „túl van”. Továbbá, ahogy a következő fejezetben a populáris müvészet autonóm almezője kapcsán (Lopes, 2002) kifejtem, egy olyan belülről is differenciált almezőről van szó, melyben az ortodoxiával való szakítás logikája, és az ahhoz való ragaszkodás évtizedekre visszanyúló konfliktusként van jelen. Az autonóm pólushoz a tekintetben közelebb álló free jazz-zenészek, hogy a termelők egy kisebb csoportjának hoznak létre a „spontán kompozíció”72 fogalmával megragadható „müveket” (szemben a sztenderdjátékkal) mégsem döntik meg, ássák alá a mainstream jazz legitimitását. Ahogy a fenti fejezetben utaltam rá, viszonyuk inkább egy állóháborúhoz hasonlít, amelyben egymást eltérő esztétika szempontok szerint osztályozzák. A kulturális legitimitások hierarchiájának

\footnotetext{
71 A mainstream táborokon belül pl. Ablakos Lakatos Dezső, Pege Aladár, a free szcénán belül egyedül Szabados György ilyen profetikus személy.

${ }^{72}$ A koncepcióról lásd az értekezés 4.9. alfejezetében írtakat. Röviden arról van szó, hogy valós időben születik meg a zene és nincsenek előre megkomponált részek.
} 
különböző szintjeiből merítő „két termelési mód”, amit a free és mainstream jazz oppozíciója jelöl, egyben a populáris kulturális gyakorlatokkal szembeni lázadás két eltérö típusaként is értelmezhető, melyet a közönség differenciálódásával és befogadástípusok szerinti rétegződéssel próbálok illusztráció szintjén megragadni.

A szórakoztató tánczenével magát tudatosan szembehelyező mainstream jazz a szélesebb közönség elvárásait nem teljesítheti, a zeneileg tipikus esetben képzetlen közönség viszont az ehhez szükséges diszpozíciók (értékelési, érzékelési és kognitív sémák) hiányában képtelen befogadni az előadások tétjeit. Meglátásom szerint ugyanakkor a jazzklubok vacsoravendégeit a jazzt egyáltalán nem hallgató túlnyomó többségtől nem a (zenei) diszpozíciók megléte vagy nemléte különbözteti meg leginkább, hanem a jazz kommerciális zenei gyakorlatokól való relacionálisan konstruált szimbolikus távolságának a felismerése. Pontosabban, a „presztízs érzete”, vagyis a mainstream jazz képviselte vélt vagy valós presztízshez való osztályhabitus kondicionálta (reflektálatlan) fölületes ragaszkodás.

Az Opus, vagy Budapest Jazz Club (nagy)polgári „kultúrsznob” közönségének „tetszése” a felszentelés karizmatikus ideológiájával (Zeneakadémia, díjak, a szakma és állami díjak elismerések biztosította kulturális legitimáció) való formális azonosulásban ragadható meg - mely maga is társadalmilag kondicionált -, szemben a zene „szakértői” hallgatásával, mely a „strukturális zenehallgatás” adornói (1998) tiszta kategóriába tartozna. Az egyébként külön nem kutatott zenehallgatási típusok nyilvánvalóan leegyszerüsített bináris megkülönböztetése a populáris zenétől való távolságot hivatott illusztrálni, melynek a befogadás modalitásaival kapcsolatos megfigyelések csak egy aspektusát képezik.

Sarkosan fogalmazva, egy popkoncerten nincs ekkora távolság kiváltságos értők, „strukturális zenehallgatók” és ,jó hallgatók” között: egy Kispál koncerten az összehasonlíthatatlanul nagyobb - közönség feloldódik a kollektív eufóriában egy-egy slágert hallgatva. A Giant Steps címü Coltrane-sztenderd (Coltrane, 1960) szaxofonszólójának élvezetéhez munka révén elsajátított diszpozíciók szükségesek, ha csak nem egyes alapharmóniák, vagy „téma” felismerésének sikerélményét tekintjük par excellence esztétikai tapasztalatnak, ennek esetlegességeitől (pl. valaki lemezboltban dolgozik eladóként és akarva-akaratlanul felismer dallamokat, zenei struktúrákat stb.) azonban e vállaltan egyszerüsítő modell tisztasága kedvéért most eltekintek. Természetesen ezek erősen sarkított példák, mert a populáris zene élvezetéhez, egy koncerten tapasztalt „kollektív eufória” élményéhez - pl. a dalszövegek megtanulásához - is szükséges „,munka”, viszont a bonyolultabb harmóniákra épülő, énekszólamot mellőző jazzkompozíciók még 
fölületes befogadásához is jóval több befektetett időre van szükség - még a fent említett Coltrane-darabnál jóval kevésbé összetett kompozíciók esetében is.

A freejazz-zenészek azok közé a „termelők” közé tartoznak, akik képesek legitim distinkciókat tenni a mainstream jazzben is. A koncertek során egy szükebb, értelmiségi közegnek játszanak, elutasítva a közönségnek tett gesztusokat, melyek egy profi mainstream zenésznél jelen vannak, pl. a játszott számok megválogatásában (a lassabb balladák és intenzívebb sztenderdek arányának megválasztásában), a színpadi jelenlétben, egy minimális dresszkódban, vagy a közönséggel való kapcsolattartásban, mely viselkedési mintákat a profi zenész attribútumának tekintik. ${ }^{73} \mathrm{~A}$ freejazz-zenészek gyakorlata egyfajta kettős lázadásban ragadható meg; egyrészt a mainstream jazz-szel szembeni lázadásban, mely a fent felsorolt gesztusok ,profán” külsőségeit is tagadja, továbbá művészi gyakorlatuk során még inkább tágítják a mediánfogyasztó várakozási horizontja és a zenei struktúra, ill. annak befogadásához szükséges értékelési sémák közt feszülö tért, mely a populáris zene és mainstream jazz viszonyában is igen széles. Az „értő” közönség mellett a fenti kategorizálást alkalmazva az értők és kultúrsznobok strukturálisan homológ alakzatait figyelhetjük meg. A szakértők, vagy „strukturális zenehallgatók” ez esetben egy szükebb „szabad zenei kört” jelentenek, kiknek „kultúrsznobjai” egy markánsan - magas kulturális tőkéjük folytán eltérő értelmiségi frakcióból kerülnek ki (egyetemisták, bölcsészek, szociológusok, nyelvészek, mủvészek, lektorok stb.), akik semmivel sem értenek jobban az adott zenéhez, mint a mainstream közönség „kultúrsznobjai”, csak ők eltérő osztályhabitusok és tőkekombinációjuk révén a free jazz reprezentálta legitimitásokhoz „,vonzódnak.”

\subsection{Jelentős harcok: A posztbourdieu-i zeneszociológiai megközelítésekről}

\subsubsection{Müvészetszociológia és a müvészetek szociológiája}

Különösen az ezredfordulótól kezdve, a kultúraszociológia tudományterülete jelentős elméleti és módszertani változásokon ment keresztül (Atkinson, 2011; Born, 2010; De La Fuente, 2010), melyek a zene szociológiai kutatásaira is hatással voltak (Prior, 2011; 2013; De Boise, 2016; DeNora, 2004). Ha valaki poszt-Marxista kultúraszociológia narratívájának megalkotását tüzné ki célul, elengedhetetlen volna számot adnia arról, hogy a

\footnotetext{
${ }^{73} \mathrm{Az}$ interjúim alapján a profi és amatőr zenész közti különbséget a zenei kvalitásokon túl - mely alapvető fontosságú - az előadói, tulajdonképpen a piacon való érvényesüléshez szükséges képességek alapján vonják meg.
} 
művészetszociológia három legtöbbet hivatkozott művének (Bourdieu, 1984, 1993; Becker, 1982) ${ }^{74}$ koncepcióit hogyan interpretálták és alkalmazták különböző szerzők eltérö empirikus kontextusokban, akár a zene szférájában. A kölcsönösen elismert különbségek ellenére is ${ }^{75}$ e két szerző „elkötelezetten szociológiai megközelitése” (Prior, 2011: 122), pontosan Becker müvészeti világ koncepciója és Bourdieu mezőelmélete, központi szerepet játszott „felmagasztalt nagy egyéniségek” müvészi gyakorlatainak varázstalanításában (Bourdieu, 1993; Grazian, 2008) olyannyira, hogy egyes szerzők a művészet szociológiáját a társadalmi és kontextuális tényezőkre történő redukcionizmussal vádolják (De La Fuente, 2007: 410; Zolberg, 1990). ${ }^{76}$

E „tiszta müvész iránti hagiografikus lelkesültséggel” (Bourdieu, 2013: 170) szakító kultúraszociológiai gyakorlatot az a konvencionális felfogás jellemzi, hogy az esztétikai tárgyak fogyasztását, termelését, terjesztését és értékelését társadalmi relációk hálózatai határozzák meg. Munka és kreativitás, kooperáció és egyéni inspiráció, stiláris innováció és konvenció ellentétei ezt az episztemológiai alapállást jól szemléltetik, ahogy Prior is felhívja rá a figyelmet (Prior, 2011: 123). Röviden, De La Fuente találó koncepcióját megidézve (De La Fuente, 2010: 8) a műalkotások „szocialitásokba” (socialities) vannak beágyazva. Másfelől, a beckeri és bourdieu-i munkákat kritizálók szerint a művészet szociológiai tanulmányozása (szemben a művészetszociológiával) ${ }^{77}$ passzív tárgyaknak tekinti a műalkotásokat, ahelyett, hogy a strukturális jellemzőkben és érzelmi hatásokban rejlő erőt és potenciált hangsúlyozná (DeNora, 2000; Frith, 1996).

\subsection{2. „Dolgok, amik összetartanak bennünket”-A hétköznapi élet és a zene mikroszociológiája}

A posztbourdieu-i zeneszociológiai diskurzusban DeNora és Hennion fenomenológiaimikroszociológiai indíttatású megközelítései a zene érzelmi, szemiotikai és szituatív aspektusait hangsúlyozzák. Hennion (2007) erős kritikát zúdít Bourdieu-re azt állítva, hogy

\footnotetext{
${ }^{74}$ De La Fuente (2007: 4) által megnevezett három legtöbbet hivatkozott mű Bourdieu Distinkciója (1984 [1979]), Az 1993-as A kulturális termelés mezője (The Field of Cultural Production), valamint Becker (1982) Müvészeti világok (Art Worlds) címü müve.

${ }^{75}$ Lásd pl. Becker és Pessin (2006), továbbá Bourdieu (1996: 204-205).

${ }^{76}$ Saját fordításomban: “A vallás mellett egyik más területet sem rombolta úgy porig a kritikai szociológia, mint a művészet szociológiáját” (Latour, 2005, idézi Prior, 2011: 123).

${ }^{77}$ Lásd De La Fuente által is alkalmazott megkülönböztetést a müvészet szociológiája (sociology of art) és müvészetszociológia (art sociology) között.
} 
az ízlést kizárólag státuszharcok kontextusában képes értelmezni, figyelmen kívül hagyva ez által az esztétikai tapasztalat individualitását, az élményszerüséget, az esztétikai tárgy sajátosságát és ami a legfontosabb a „fogyasztó” aktív, jelentéskonstrukcióban meghatározó szerepét:

(...) azt hiszed, hogy szeretsz dolgokat, mikor nem, [csupán] a miliőd, a származásod, a képzettséged melyek lehetővé teszik, hogy értékeld azokat. Vagy még inkább, à la Bourdieu, magának ennek az illúziónak a mechanizmusa az, ami alakítja a preferenciákat. Ez a megközelítés teljesen passzív képet fest a determinizmusról (Hennion, 2007: 102). ${ }^{78}$

A neves kortárs szerző megközelítésének lényegét jól illusztrálja az „,ízlés mint tulajdonság” (taste as property) kontra ízlés mint „cselekvés” (taste as activity) oppozíciója. Bourdieunél a müélvezet nem autonóm esztétikai tapasztalat, hanem státusz- és pozícióharcok instrumentuma. Hennion a homológia-tézist is kritizálja a zenei élmények szituativitását hangsúlyozva. Például a „milyen zenét szeretsz hallgatni?” kutatási kérdés rosszul van megfogalmazva, mert nem egyeztethető össze az egyén valós gyakorlatával, aki számára nem valami felsőbbrendủ kánon kiválasztása, vagy megalkotása a tét, hanem a hangulatának, pszichológiai/érzelmi állapotának leginkább megfelelő alkotás kiválasztása. Tehát a körülmények, a leginkább szubjektív kondíciók elmeállapotok szituatív valóságában nyeri el jelentését a zenemü, melyet hallgató és a zene maga együtt hoz létre. Másfelől a zene baráti, családi stb. közösségeket összetartó kollektív gyakorlatok eszköze is lehet (Hennion cikkének címe Those Things that Hold us Together), egy lehetőség arra, hogy megbeszéljük mi közös bennünk, mit szeretünk vagy éppen mit tartunk ízléstelennek, de nem életstílusosztály(ok)ba sorolt társadalmi pozícióink újratermelésének, teljes összefüggéseiben csak az omnipotens szociológus által ismert instrumentuma.

Frith-el, és Hennionnal egyetértésben, DeNora is a zene hanghatáson alapuló tulajdonságaira (sonic properties), érzelmi erejére hívja fel a figyelmet, valamint a mindennapos zenehallgatás (DeNora, 2000) dialektikus természetének vizsgálata során ő is a fogyasztó aktív, „koprodukciós” szerepét tekinti meghatározónak a zenei jelentés megteremtésében (Varriale, 2016: 164). Az egyébként Adornóról is elismert monográfiát jegyzőt DeNora Music in Everyday Life [Zene a mindennapi életben] c. könyvét a zene

\footnotetext{
${ }^{78}$ Fordításomat vesd össze a szöveg angol verziójával: „(...) you think you love things, when no, it is your milieu, your origin, your formation that makes you appreciate them. Or even more, a la Bourdieu, it is the very mechanism of this illusion that forms the preference. This is a completely passive vision of 'determinism."
} 
mindennapi tevékenységeket, rituálékat, hangulatot és szokásokat meghatározó szerepének szenteli, ahol a szociológia mellet pszichológiai és szociolingvisztikai referenciák alapján teoretizálja a társadalmi rend esztétikai dimenzióját. A pszichológiából pl. átveszi az „affordancia” fogalmát, mely alatt a zenei darabokban a hallgatók számára rejlő szemiotikai és érzelmi lehetőségeket érti. Noha Hennion és DeNora megközelítései elmozdítják a fókuszt egyén és kultúra egyenrangú viszonyának mikro-dinamizmusa és az esztétikai tapasztalat „kontextuális autonómiája” felé, kevésbé képesek számot adni társadalmi pozíció és kulturális aktivitás, ill. a hierarchizált szimbolikus különbségtételek logikájáról, melyek a müalkotások szerkezetét és tartalmát is befolyásolják, túl a kultúrafogyasztó egyének szándékain és szubjektív esztétikai tapasztalatán. ${ }^{79}$

\subsubsection{Homológia és mindenevők: a kultúraszociológiai erőtér polarizálódásának egy aspektusa}

A relacionális esztétikai tapasztalatok és jelentéskonstrukciók mikro-dinamikája felé (Benzecry és Collins, 2014; DeNora, 2000; Hennion, 2007) történő eltolódást hangsúlyozó „(D)distinkción túli” posztbourdieu-iánus kutatások mellett (Varriale, 2016), a homológia tézissel (Hanquinet és Savage, 2016; Chan és Golthorpe, 2007; Peterson, 1992; Veenstra, 2010 stb.) és a mezőelmélettel kapcsolatos (Prior, 2008; Regev, 2013) Bourdieu-kritikus trendekről érdemes még szót ejteni. Az amerikai kultúraszociológia egyik leginkább meghatározó alakjának, Richard Peterson „kultúratermelésből” kiinduló (the production of culture perspective) (Santoro, 2008) első írásaitól kezdve (Peterson, 1992; Peterson és Simkus, 1992) egyre inkább elterjedt a „kulturális mindenevőkkel” kapcsolatos empirikusan igazolt elképzelés társadalmi (osztály)helyzet és kultúrafogyasztás viszonyáról. Az ízlés és osztályhelyzet statisztikai kapcsolatára, valamint az összehasonlíthatóság módszertani kihívásaira megkülönböztetett figyelmet szentelő Peterson (2005) nagymintás kutatásai során kimutatta, hogy - szemben Bourdieu elképzelésével, melyet a '60-as évek Párizsban gyüjtött adatokra alapozott és ezekből ,általánosított” - a magas társadalmi státuszt eklektikus kultúrafogyasztás minták jellemzik, és nem kizárólag egysíkú magaskulturális („,highbrow univore”) érdeklődés.

\footnotetext{
79 A két nézőpont közti különbséget szemléltetendő, egy számomra kedves példával élve, élezheti valaki Vinterberg Születésnap c. filmjét a nélkül is, hogy a dán filmes mező szerkezetét behatóan ismerné, azonban az ún. dogmafilmek esztétikája már kevésbé érthető meg az Hollywood jelképezte amerikai filmkészítés klisés konvencióival szembeni lázadás kontextusán kívül.
} 
Az '60-as és '70-es évek generációs váltása során a magas társadalmi státuszú ügyvéd pl. nem csak operába, vagy hangversenyre jár, de mellette jazzt és rock zenét is hallgat. Az alacsonyabb státuszú népesség pedig inkább kulturálisan egysíkú („univore”) és a tipikusan olyan kispresztízsü („lowbrow”) zenéket preferálja, mint a rap, vagy a country. Az eklektikus fogyasztási „,pattern” tehát Peterson kulturális mindenevőkkel kapcsolatos tézise szerint a magas státuszú társadalmi csoportokat jellemzi, melynek (statisztikai) kimutatásához a Bourdieu által hangsúlyozott, de részleteiben külön nem elemzett ${ }^{80}$ zenei preferenciák különösen jól használható szociológiai indikátorok.

Ez a felfedezés meglehetősen polarizálta a kultúraszociológiai erőteret: a fent is felsorolt szerzők védték, árnyalták, vagy alátámasztották egyik vagy másik réteghelyzet és kultúrafogyasztás kapcsolatát leíró tézis helytállóságát különböző empirikus kontextusokban és eltérő módszerek alkalmazásával. ${ }^{81}$ A „homológia” kontra „mindenevők” dichotómia felől nézve, az értekezésem inkább azon „kvalitatív ellentámadások” szellemében íródott (lásd pl. Atkinson, 2011), melyek Bourdieu elméletének árnyalt, átfogó és nem kilúgozott-leegyszerüsítő alkalmazását tüzik ki célul egyes müfajokon belüli distinkciók kvalitatív módszertannal való elemzései során. Atkinson (2011) például a zenei ízlés társadalmi genezisének interjúelemzésre épülő vizsgálata során amellett érvel, hogy Bourdieu Distinkcióban lefektetett kulturális különbségtételekkel kapcsolatos tézisei igazolhatók, ha a (disz)preferenciák (!) mellett az adott zenei müfajokhoz való különböző interjúkban megnyilvánuló viszonyulási módokat (,modalitásokat”) is figyelembe veszi a kutató. ${ }^{82}$ Például Ságinál $(2010)^{83}$ a „,dzsesszkoncertek” látogatása az „opera mellett” a

\footnotetext{
${ }^{80}$ Legalábbis a kritikák szerint Bourdieu nem elemezett zenei erőtereket olyan alapossággal, mint az irodalmi, vagy festészeti mezőt (pl. Bourdieu, 1996).

${ }^{81}$ Nem véletlen, hogy Peterson (2005) külön figyelmet szentel az összehasonlíthatóság problémájának. További tendencia még, hogy a kvalitatív kutatások nagy része jellemzően a homológia-tézis mellett tör lándzsát (pl. Atkinson, 2011), míg a kvantitatív kutatások sokszor triumfálnak a '60-as évek Párizsából nyert adatok „külső érvényességének” az általánosíthatósággal kapcsolatos vélt vagy valós hiányosságai fölött (pl. Lamont, 1992). Mások, mint Veenstra (2010) ennél óvatosabb állásponton vannak és a bourdieu-i gondolkodás heurisztikus erejét hangsúlyozzák a homológia-tézist tesztelő nagymintás kutatásoknál is.

${ }^{82}$ Akinson (2011) életúttal és életstílusokkal kapcsolatos interjúk alapján rekonstruálja osztályhelyzet és zenei preferenciák homológ viszonyait bristoli fiatalok körében.

${ }^{83}$ A Bevezetőben említett ELTE TÁTK és TÁRKI összefogásával megvalósuló müvészetszociológiai kutatás (Wessely, 2012) egyik eredményéröl van szó, mely Bukodi (2007, 2010) írásai mellett a kulturális szegmentáció összefüggéseit tárgyalja elméletileg megalapozott módon, reflektálva a Peterson által is osztályozott kultúrafogyasztási típusokra.
} 
kulturális mindenevőknél nagyobb arányban van jelen (slussz-passz), vagyis - ahogy tipikusan a klasszikus zene is - meggyőző szociológiai indikátora a magas társadalmi státusznak. Ebből a szempontból nézve meglehetősen extrémnek hathat majd négy éven át kizárólag ilyen „rétegzenével” foglalkozni, mint a jazz, noha pont arról van szó, hogy „egy jól konstruált egyedi eset, megszünik egyedi lenni” (Bourdieu és Wacquant, 1992: 77), ${ }^{84}$ vagyis egy-egy müfajon belüli megkülönböztetett különbségek és legitimitáshierarchiák vizsgálata a kutatott tárgyon (látszólag) kívül eső társadalmi viszonyokat képezhet le. ${ }^{85} \mathrm{~A}$ különböző irányultságú Bourdieu-kritikus vagy Bourdieu elméleteit empirikus kontextusokban alkalmazó kutatások újabb és újabb fogalmak térnyeréséhez vezetnek, melyek aztán a nemzetközi kultúraszociológia erősen kompetitív, többpólusú erőterében méretettnek meg. ${ }^{86}$ Ahogy Varriale (2014: 57) is rámutat, nincs egyetértés abban, hogy a populáris zene kedvelése feltétlenül a „kulturális mindenevőkre” lenne jellemző. Míg korábban a „mindenevők” eklektikus (zene)fogyasztási mintái a kulturális tolerancia indikátorai voltak, újabb tanulmányok azt hangsúlyozzák (pl. Rimmer, 2012), hogy à la Adorno (1998), a „zenével kapcsolatos magatartások típusainak”, illetve zenei interakció vizsgálata legalább olyan fontos, mint egyes műfajok belső differenciálódását nem ismerő ahogy az osztályozott csoportok osztályozható osztályozó gyakorlataira sem reflektáló szociológusok által azokhoz mégis tipikusan státuszkategóriákat rendelő müfajok közti feltételezett hierarchikus viszonyok vizsgálata.

\footnotetext{
84 'A particular case that is well constructed, ceases to be particular' - fordítás az angolból saját: H.Á.

${ }^{85}$ Vö. Bourdieu (1990) fotómüvészetről írt könyvével, melyben eltérő státuszú egzisztenciáknál kérdezett rá, hogy egy-egy tárgy pl. mennyire ,legitim” tárgya lehet egy fényképnek, és elemezte milyen szerepet tölt be a fotózás pl. családi eseményeken arra a következtetésre jutva, hogy a fotózás közepes legitimitású müvészet a legitimitások hierarchiájában.

86 Atkinson (2012) például a Bourdieu-höz való viszony alapján megkülönbözteti a francia szociológus örökségének követőit és kritikus tagadóit (critical repudiator), nem beszélve Bourdieu munkásságát az inszinuálástól sem visszariadva „,szociológiai terrorizmusnak” címkéző Verdés-Leroux (2001) könyvéről, mely kis jóindulattal sem sorolható az Atkinson által „tagadóknak” kategorizált Miche’le Lamont-hoz, vagy Crossley és Bottero hálózatelemzési megközelítést képviselői cikkeihez (pl. Bottero és Crossley, 2011).
} 


\subsubsection{A heteronóm pólusok kultúraszociológiája és a „kvázi-felszentelt” gyakorlatok pozíciói}

Ahelyett, hogy az esztétikai tapasztalatok sokszínűségét hangsúlyozó megközelítéseket és kutatási trendeket értékelném, ${ }^{87}$ vagy kísérletet tennék egy „gyakorlatilag megalapozott” és „empirikusan árnyalt” (De Boise, 2016: 179) zeneszociológia kontúrjainak felvázolására, a továbbiakban a kutatásom szempontjából kifejezetten hasznosítható, a bourdieu-i mezőkonstrukció alkalmazásával összefüggő kultúraszociológiai diskurzusra koncentrálok. Ezen zeneszociológiai munkák kontextusában a megközelítésem alapvetően azokhoz a kutatásokhoz sorolható, melyek differenciálják a mezőelméletet különböző - tipikusan a 20. század második felében létrejövő - populáris zenei kontextusokban, ahelyett, hogy eleget tenne egy ,posztbourdieu-i zenekutatási agenda” kidolgozásával kapcsolatos egyre növekvő igényeknek (lásd pl. De Boise, 2016). Egy mindent átfogó zeneszociológiai kutatási paradigma kidolgozásával kapcsolatos alapvető szkeptikus álláspontomon túl, inkább azt igyekszem hangsúlyozni, hogy a késő- vagy „folyékony” modernitás (Bauman, 2000) különböző legitimitású referenciáiból táplálkozó kulturális erőterek empirikus kontextusaiban a mezőkonstrukció modellje kiválóan müködtethető. Ez akkor is így van, ha a meződinamikára vonatkozó egyes hangsúlyokat máshová is teszi az elmélet alapelveiből kiinduló kutató, pl. olyan „félig-felszentelt” mezők (Varriale, 2015) elemzése során, melyeket Bourdieu maga nem elemzett mélyrehatóan termékeny életmüvében. Az egyik legélesebb kritikát Bourdieu-vel kapcsolatban Hesmondhalgh (2006) fogalmazza meg egy tanulmányának beszédes címet viselő fejezetében (,,Mintha a kulturális ipar létre sem jött volna"), ${ }^{88}$ melyből érdemes hosszabban is idézni:

Minden erejével együtt, azonban a kulturális termeléssel kapcsolatos bourdieu-i szociológiának meghatározó korlátai vannak, ha a kortárs kulturális termelés területének elemzésre gondolunk. Egyszerüen megdöbbentő milyen kevés mondanivalója van Bourdieu-nek a tömeges, „heteronóm” kommerciális kulturális termelésről, nem csak e terület kortárs világban betöltött hatalmas társadalmi és kulturális fontosságát tekintve, de annak a korlátozott termelés

\footnotetext{
${ }^{87}$ Ahogy részben tette pl. Varriale (2014, 2016), Prior (2013) és DeBoise (2016).

${ }^{88}$ A fordítás az angolból „Like the cultural industries never happened” (Hesmondhalgh, 2006: 217) a sajátom: H.Á.
} 
almezőjének viszonyaira vonatkozóan meghatározó szerepe miatt is, amely utóbbi világos, hogy Bourdieu-t jobban foglalkoztatta (Hesmondhalgh, 2006: 217). ${ }^{89}$

Az angol kultúratudós éles kritikája - melyet föleg a Müvészet Szabályaira, de Bourdieu más kultúra- és mủvészetszociológiai munkáira is alapoz - meglehetősen explicit módon a kulturális termelés „heteronóm”, piaci-kereskedelmi hatásoknak kitett területeinek mély elemzéseit kéri számon Bourdieu-n. Néhány pozitív példától eltekintve - ide sorolja Hesmondhalgh pl. Bourdieu (1998b) televízióról és francia sajtóról szóló elemzéseit - a populáris kultúra elemzésével kapcsolatos relatív ignoranciájának az elméletre nézve is következménye van. Saját empirikus kutatásra épülő korrekciókat azonban a szerző itt nem eszközöl, helyette a mezőelmélet és az elsősorban angolszász interakcionista, institutcionalista és kritikai média-tanulmányokkal kapcsolatos nézőpontok szintézisét, és a korporatív alapon szerveződő modern tömegmédia intézményeinek differenciált elemzéseit javasolja.

Lopes modern amerikai jazzről írt - történeti-szociológiai - esettanulmánya már jól példázza a kulturális mező bourdieu-i modelljének empirikusan megalapozott differenciálását, illetve „expanzióját” (Lopes, 2002: 167). Munkájában elsősorban arra volt kíváncsi, hogy a populáris és klasszikus zenei gyakorlatokból egyaránt merítő - Lopes kifejezésével élve - hibridjazz-paradigma milyen pozíciót tölt be az amerikai kulturális termelés mezőjében. A francia mester munkásságát komolyan véve, elemzése során a zenei mező szerkezetéből és intézményrendszeréből kiindulva felteszi a kérdést, hogy a jazz kulturális hierarchiában betöltött pozíciója mennyire megragadható Bourdieu kulturális termelési mezőre vonatkozó tipológiájával. Érvelése szerint, a populáris müvészet autonóm almezője $e^{90}$ egy relatív autonómiával bíró pozíció az amerikai kulturális termelés mezőjében, mely történeti konstruáltságánál fogva sem a korlátozott termelési almezőbe, sem a

\footnotetext{
${ }^{89} \mathrm{Az}$ idézet ismét saját fordításom, melynek eredeti angol verzióját is közlöm a két verzió összevetésének lehetőségét megteremtve: „For all its strengths, however, Bourdieu's sociology of cultural production has important limitations when it comes to analysing contemporary cultural production. It is simply astonishing how little Bourdieu has to say about large-scale, 'heteronomous' commercial cultural production, given not only its enormous social and cultural importance in the contemporary world, but also its significance in determining conditions in the sub-field in which he is clearly much more interested, restricted production."

90 Emlékeztetöül, a ,the restricted subfield of popular art” terminust a magyarra a ,populáris müvészet autonóm almezőjének” fordítom a „populáris müvészet korlátozott termelési mezője” helyett (lásd jelen doktori értekezés 22. oldalát).
} 
kommerciális polgári („,burzsoá”) almezőbe, sem pedig a kommerciális-ipari (,populáris”) művészet almezőjébe nem illeszthető. Mielőtt folytatnám annak bemutatását milyen jelentőséggel bír a hibridjazz-paradigma Lopes által detektált pozíciója a kutatásom számára, egy rövid kitérő erejéig visszatérnék a kulturális termelés mezők dinamizmusát meghatározó fő tipológiára. Bourdieu alapján ugyanis mindkét „szélső pólus”; a (Seregi által „nagytermelésnek” fordított) tömeges termelés és korlátozott termelés (vagy „tiszta termelés pólusa”) ${ }^{91}$ is ,a közönség mennyisége és társadalmi minősége” alapján (Bourdieu, 2013: 242) almezők szerint differenciálódik, ahogy az előző fejezetben bemutattam. Lopes érvelésében a jazz-zenei almező kialakulása a többpólusú zenei mező intézményesülésének következménye, ahol a két szélsőséges pólust a klasszikus zene reprezentálta „tiszta” müvészet és a kommerciális kultúripar belülről is differenciált pólusai jelölték ki.

Míg a populáris művészet autonóm almezőjének státuszát (zene)kritikusok, valamint egyes zenei müfajokhoz köthető zenei szubkultúrák prominensei határozták meg, addig az ipari müvészetet (industrial art) a tömegpiac mediatizált kereslete és ,elvárásai” formálták. ${ }^{92}$ Történeti szemszögből Lopes szerint a relatív autonómiával bíró jazz a zenei mező egyik szélsőséges pólusához sem sorolható. A jazz legitim definíciója körüli harcok során a jazz különböző irányzatok (cool, hardbop, fúzió, free jazz stb.) szerint differenciálódott, de a relációk és a harcok tétjei nem érthetők meg teljességgel a „müvészi zene” és populáris zene oppozíciója alapján, noha (strukturális homológiákat feltételezve) mindkét „tiszta pólus” referenciáiból merít. Lopes esettanulmányát kissé absztrahálva azt mondhatjuk, hogy pénz és müvészet közti ellentét strukturáló erejét differenciálta a jazz történeti genezisének elemzése kapcsán Amerikában. Bourdieu a müvészet és pénz strukturáló erejéről a következőképp ír:

\footnotetext{
${ }^{91}$ Az eredeti franciában szereplő „le pôle de la production pure” (amely jelentését tekintve megegyezik az angol „the pole of pure production” fordítással is), a Seregi-féle fordításban mint ,tiszta alkotás pólusa szerepel” a „tiszta termelés pólusa” helyett, mely megfogalmazás (alkotás $\neq$ termelés) a „müalkotásra” való esetleges áthallásokon túl nem adja át a „termelés” közgazdaságtanból Bourdieu által tudatosan átvett és differenciált terminusát. Ez a megfogalmazás véleményem szerint elfedi a mezőelemzésben kulcsfontossággal bíró különböző termelési módok (,mode de production”) közti alapvető megkülönböztetést.

92 Bourdieu a 19. századi színházi mező kapcsán a La Croix kritikusát idézve beszél ,avantgárd-bulvárról”, illetve a klasszikus színházak „semleges” programjairól, melyek képesek közönségüket a „hatalmi mező minden régiójából meríteni” (Bourdieu, 2013 [1992]: 184). Ez azonban nem analógia a Lopes által jazz kapcsán leírtakra, mertaz a jazz modernista fordulatát követően, az '50-es évekre létrejövő zenei áramlatot egy relatív autonómiával bíró, belülről is differenciált kulturális almezőként definiálja.
} 
A mủvészet és a pénz („kereskedelmi”) közötti ellentét az alkotóelve azon ítéletek többségének, amelyek (...) megpróbálnak határt vonni művészet és nem művészet, „polgári művészet” és „értelmiségi művészet”, hagyományos és ,avantgárd művészet” közé (Bourdieu, 2013 [1992]: 184-185).

A jazz épp ezért is válik izgalmas elemzési tereppé Amerikában és máshol, mert ,a művészet és pénz” Bourdieu által meggyőzen hangsúlyozott, „mentális struktúrákban” is müködő oppozíciója e kulturális erőtér hierarchikus viszonyaiban eltérő súllyal van jelen. Tovább „vulgarizálva” Lopes-t már a kortárs ,posztbourdieu-i” kultúraszociológia populáris müfajokon belüli és müfajok közti relációkat vizsgáló kontextusában, ezen újonnan létrejövő (zenei) stílusok elemzésének kiindulópontja hasonló a Birminghami Iskola szubkultúrák elitizmusát és exkluzivitását is előtérbe helyező kutatások neomarxista nézőpontjához, csak a kultúraszociológiában megkerülhetetlen domináns - mondhatnám mainstream autoritásként tekintett Bourdieu többé-kevésbé elsajátított paradigmájának alkalmazásával. Összefoglalva, a „heteronóm gyakorlatok” kultúraszociológiai elemzései a Bourdieu által figyelmen kívül hagyott, vagy sokkal inkább kevésbé elemzett, sokszor (a piacnak való kitettsége folytán) „homogénnek” tekintett kulturális erőtereken belüli distinkciókra irányítják a figyelmet. A (kultúra)szociológia tehát felfedezi magának a popkulturális erőterek belülről differenciált, a legkülönfélébb társadalmi keresztmetszetek dimenzióiban heterogén világát, melyben olyan kvázi-felszentelt (Varriale, 2015: 4), a legitimációk határán lévő kulturális gyakorlatok, mint pl. a krimi, graffiti, képregény, sci-fi stb., megítélése koránt sem egyértelmü, és a különböző presztízzsel bíró referenciákon nyugvó interpretációs stratégiáktól függ. Megítélésem szerint a magyar jazz diaszpóra is ebbe az ambivalens legitimációjú kategóriába sorolható, és épp a kulturális értelemben vett hibriditása folytán válik izgalmas elemzési tereppé a mezőelméletből kiinduló kutató számára.

A fenti, teljesség igényét jócskán nélkülöző irodalmi összegzéssel azt a módszertani alapállást kívántam megalapozni, hogy az empirikus fejezetek során nem pénz és művészet strukturáló ellentétét fogom elötérbe helyezni, sem pedig a zenészek és közönség szituativitását, „itt és mostját” hangsúlyozó fenomenológiai nézőpontot a művészet relacionális esztétikai tapasztalatát (relational encounter) (Varriale, 2015) illetően. A különbözö zenei habitussal rendelkező zenészek osztályozó és osztályozott gyakorlatainak elemzése során nagyobb hangsúlyt fektetek a sajátos magyar történeti kontextussal 
összefüggő különböző plurális kulturális referenciák (Bartók, free jazz, szabad improvizáció, népzene) strukturáló erejére, mint a pénz és „tiszta” művészet ellentétére. Történeti, esztétikai és kulturális okoknál fogva nem tételezek strukturális ekvivalenciát az amerikai kontextusban releváns jazz müfajára (is) hatással lévő country, blues vagy gospel irányzatok, és például a magyar viszonylatban meghatározó bartóki vagy népzenei referenciák között. Továbbá, a piacellenesség ethosza a magyar jazzszcénában nem ragadható meg a korlátozott termelési mező struktúráját meghatározó két termelési mód (felszentelt avantgárd és „eretnek avantgárd”) ellentétével: ahogy az empirikus elemzések során kifejtem, a mainstream/free jazz ellentét nem redukálható az ortodoxia és „eretnek” újítók közti ellentétekre, hiszen a free jazz is bő fél évszázada létezik már. E '70-es évekre visszavezethető konfliktusban a free- és mainstream táborok közötti, társadalmi rétegződéssel és etnikummal összefüggő különbségek és a kulturális referenciák osztályfrakciókhoz köthető interpretációs stratégiái játszanak döntő szerepet. Ebben az állóháborúban - ahol ugyanúgy találunk „dezertőröket”, „kettős ügynököket”, mint „parancsnokokat” és „legyőzötteket” - nem győzedelmeskedik az új generáció a dogmatikus idősek fölött, hanem, bizonyos átjárásokkal ugyan, két eltérő esztétikai-ideológiai elvrendszeren nyugvó alapállás áll szemben, amelyek még arról is eltérő definíciókat alkotnak, mi tekinthető egyáltalán jazznek vagy zenének.

\subsection{Zenei habitus}

Rimmer (2012) kvalitatív kutatásaiban a bourdieu-i habitusfogalom alapján konstruált zeneihabitus-koncepció alkalmazásának előnyeire hívja fel a figyelmet, kiváltképp a zenei ízlés státuszharcban betöltött szerepének értelmezése során. A zenei habitus alatt a tartós diszpozíciók (kognitív, cselekvési és értékelési sémák) rendszerének a zenében való megjelenését értjük. Rimmer definíciója szerint (2012: 306), „a zenei habitus egy magyarázó eszközt kínál az egyének zenével való viszonyáról", mely társadalmi helyzet által kondicionált viszony a szocializáció során felhalmozott és belsővé tett kulturális tőkékkel áll összefüggésben. A zenei habitus alkalmazásával a kutatónak lehetősége nyílik a zenei kifejezőeszközök megválasztásának logikáján túl, a zenehallgatás módozatainak és a különböző (zenei) stílusokat osztályozó gyakorlatok társadalmi alapelveinek megragadására is. A fogalom alkalmazása az etnikum, a származás és az esztétikai praxisok közti kapcsolatok értelmezésével kecsegtet a kortárs jazz-zenei mező kontextusában, röviden, a 
társadalom egyéb viszonyrendszereiben is igazodási alapként tételezett habitus zenei vonatkozásait jelenti.

Rimmer tanulmánya explicit kritikáját adja a társadalmi pozíció (osztályhelyzet) és ízlés kapcsolatát vizsgáló kvantitatív kutatások kiterjedt irodalmának (Chan és Golthorpe, 2007; Peterson, 1992), melyek sokszor „általánositó képet festenek” (Rimmer, 2012: 313) ${ }^{93}$ ízlés, kultúrafogyasztás és társadalmi pozíció viszonyáról. ${ }^{94}$ A zenei habitus alkalmazása a müfajokon belül müködő klasszifikációs sémák pontosabb megértésével kecsegtet, mely alapvető fontossággal bírhat az egyes stílusok belső differenciáltságát esetenként nem kellő súllyal tárgyaló (lásd pl. Atkinson, 2011), kultúrafogyasztás és réteghelyzet összefüggéseit nagy mintán vizsgáló elemzések számára is. A habitus zene szférájában való alkalmazása önmagában nem tekinthető fogalmi újításnak, maga Bourdieu is számos habitus-típust különböztet meg; nyelvi habitust (1991: 81), akadémiai habitust (1988), dzsenderhabitust (2001) sőt, kutatói stratégiájának meghatározó része a Distinkcióban lefektetett reprodukciós logikába illeszthető mezőelmélet különböző társadalmi kontextusokban való müködtetése. ${ }^{95}$ A közös nevező, amiért a különböző habitustípusok megkülönböztetése elméletileg lehetséges, a meződinamika alapelveinek azonosságából fakad: a mezők szerkezetét és kialakulását meghatározó relációk és pozíciószerzések logikája azonos szabályok mentén szerveződik (lásd Bourdieu, 1993, 1996; Maanen, 2009). A nemzetközi irodalomban bevett „mezőelemzés” (field analysis) ${ }^{96}$ különböző nemzeti kontextusokban ezekben az alapmüvekben lefektetett elveket veszi alapul akkor is, ha a bourdieu-i elméletből kiinduló szerzők a mezőelmélet differenciálására törekednek (Varriale, 2015; Hesmondhalgh, 2006; Prior, 2007), vagy erősen kritizálják annak alkalmazhatóságát a későmodern kulturális viszonyok közt (Hennion, 2007; Lamont, 1992).

\footnotetext{
93 Saját fordításom: H.Á.

94 A stílusokat átfogó nagy gyüjtőkategóriák (jazz, rock, techno stb.) a müfajokon belüli distinkciókat sokszor elfedik. Rimmer joggal hívja fel a figyelmet egy-egy stíluson belüli alvariációk jelentőségére, pl. csak a metálzenében megkülönböztethető legalább 10 alfajt szélesebb társadalmi distinkciók indikátorának is tekinthetjük.

95 Lásd Hadas Bourdieu Férfiuralmáról (2015) szóló tanulmányát, mely „,paradigmaexpanziónak” értelmezi a habitus társadalmi nemekre való kiterjesztését, pl. a libido dominandi bourdieu-i kulcskoncepció mint maszkulin habitus értelmezhető.

${ }^{96}$ A nemzetközi kultúraszociológia nívós orgánuma, a Cultural Sociology 2013-ban külön számot is szentelt e kutatási gyakorlatnak, melyben eltérö módszertani apparátust felvonultató szerzők különböző nemzetek kulturális mezőinek elemzései mellett elméleti-összegző cikkeket is publikáltak (pl. Savage és Silva, 2013).
} 
Korábbi tanulmányaimban (Havas, 2017a, Havas és Ser, 2017) a jazz-zenei mezőt egy olyan erőtérnek értelmeztem, melyet a legitim jazz-definíció ki- és elsajátítási harcai jellemeznek, mely harcok logikája pontosan megragadható a mainstream és free jazz különbségétételt meghatározó főbb oppozíciók által. Ilyen alapoppozíciónak tekintettem például a professzionális (a freejazz-zenészek által pejoratív felhanggal „technokratának” címkézett) mainstream jazz-zenész és az autonóm müvész zenei kompetencián túlmutató ethoszának ellentét, melyet - és különböző aspektusait - mélyinterjúk alapján rekonstruáltam. A mezőelmélet konfliktuselméleti megközelítéséből egyrészt a szimbolikus és gazdasági profitok kijelölte erőtérben folyó legitimációs harcok logikáját megragadó komplex fogalmi hálót veszem át, másrészt azt a már említett relacionális szemléletet, mely a tudatosan reflektál arra, hogy a kutató által osztályozott csoportok - esetünkben a free és mainstream zenészek - egyben sajátos habitusok mentén osztályozó és típusalkotó csoportok is. Ebben az elméleti keretben a zenészek pozíciószerzéseinek alapelvei értelmezhetők az oppozíciós logika mentén szerveződő racionalizálási stratégiák mentén, melyek alatt a különböző pozíciókat betöltő zenészek legitimációs esztétikai-ideológiai diskurzusait értem, amelyek tipizálására szintén kísérletet teszek.

A magyar jazz - azon belül is a mainstream és free jazz distinkció - továbbá azért izgalmas elemzési terep, mert e középszintű erőtér történeti és társadalmi kondicionáltságánál fogva sajátosan képez le szélesebb társadalmi viszonyrendszereket, valamint azok esztétikai elvekben és gyakorlatokban megjelenő jelentéseit. Egyetértésben azon szerzőkkel, akik e kulturális gyakorlat belső hierarchizálódását etnikummal, rasszal és más szélesebb kulturális jelenségekkel hozzák összefüggésbe (Lopes, 2002), a '60-as években intézményesülö ${ }^{97}$ magyar jazz-zenei mező prizmája is megtöri a társadalom strukturális rendjét, és sajátos működésmódja alapján leképezi azt. Az empirikus elemzés 5. fejezete Magyarország „kvázi feketéinek”, az urbánus, cigány származású jazz-zenészek zenei diszpozíciónak vizsgálatát kínálja, és a zeneihabitus-koncepció alkalmazásával azt próbálja megragadni, hogy e muzsikusok miért részesítenek előnyben bizonyos művészi kifejezőeszközöket másokkal szemben. Elsősorban roma származású zenészekkel készített interjúk rekonstrukciójára és etnográfiai sủrü leírásra támaszkodva az elemzés során a (koragyermekkori) zenei szocializáció Rimmer (2012) által túlhangsúlyozott szempontjai

\footnotetext{
${ }^{97}$ Lásd Havadi írását a jazzklub hálózatról, valamint a kiváló forrásértékkel bíró Jazz Studium DIY kiadványt (1982-1990), mely maga is intézményesítette a free és mainstream jazz ellentétét, lévén elsőssorban a free jazz referenciákat kanonizálta Magyarországon.
} 
mellett, a rokonsági viszonyok szerepére, valamint a szocializáció révén kondicionált esztétikai preferenciák életvitelben is magragadható sajátosságaira is kitérek.

\subsection{A kutatás relevanciája a kritizált Bourdieu-recepciók kontextusában}

A kutatás tudományos relevanciája kapcsán a magyar Bourdieu-recepció relatív szegénysége fontos érv. ${ }^{98}$ Bourdieu magyarországi társadalomtudományos recepcióját (annak szegénységét) jól szemlélteti, hogy a magnum opusnak is tekintett Distinction (1984 [1979]), melyet 1998-ban a Nemzetközi Szociológiai Egyesület (ISA) minden idök legfontosabb 10 szociológiai munkája közé választott, ${ }^{99}$ nincs lefordítva magyarra. ${ }^{100}$ Seregi Tamás munkájának köszönhetően, A müvészet szabályainak (Bourdieu 1996 [1992]) magyar fordítása (2013) mérföldkőnek tekinthető Bourdieu művészet- és kultúraszociológiai tudományos nézeteinek elterjedése szempontjából a magyar tudományos életben, az elméleti fejezet elején felsorolt néhány kritika ellenére is, melyek főleg az irodalomtudomány, esztétikai és filozófia (szellem)tudományi nézőpontjait képviselő Seregi „szabad” fordítói megoldásaira vonatkoztak.

A fordítások hiánya mellett Bourdieu magyarországi recepciójával összefüggésben fontos említést tenni a fordítással és interpretálással összefüggő szakmai problémákról, melyek megnehezítik a Bourdieu-ről való (magyar) tudományos diskurzus kialakulását. Ilyen problémákra hívja fel a figyelmet Hadas (2002) a Férfiuralom (Bourdieu, 2000 [1998]) és Wessely (2005) A tudomány tudománya és reflexivitás (Bourdieu, 2005 [2004]) hanyag magyar fordításából származó értelmezési problémák kapcsán. Ahogy például Wessely írja a fenti mü magyar fordítása kapcsán: „Az olvasónak az a benyomása támad, hogy a forditók titkon meg voltak gyözödve arról, hogy a szöveg jórészt eleve értelmetlen, tehát magyarra is csak igy ültethető át. Meg sem próbálták értelmezni” (2005: 229). Jelen kutatás, egyrészt, részeredményeinek publikálása által fontos adalékul szolgálhat a neves francia szociológussal kapcsolatos szakmai diskurzusok létrejöttéhez, másrészt a bourdieu-i művészetszociológiai szemlélet legitimitását is növelheti a magyar tudományos mezőben.

\footnotetext{
98 Bővebben a magyarországi Bourdieu-recepciókról lásd: (Hadas, 2001; Wessely, 2005).

${ }^{99}$ Más szerzők, például Ollion (2015), Truong és Weill (2012) és De La Fuente (2007) is azt támasztják alá, hogy Bourdieu kétség kívül az egyik legtöbbet hivatkozott modern szociológus.

${ }^{100}$ A majd 700 oldalas müből magyar nyelven csak néhány fejezet elérhető, pl. Bourdieu (2010 [1979]) Fáber Ágoston fordításában.
} 
A kutatás nemzetközi relevanciáját illusztrálja egy 2014-ben a JSTOR internetes adatbázisban folytatott egy órás minikutatás is, mely a „genezis”, ,irodalmi mező”, „,színházi mező”, „genezis és struktúra” terminusok angol megfelelőinek szisztematikus keresésére épült az adatbázis keresőmotorjának felhasználásával. A keresés alátámasztotta a feltételezést, hogy a művészeti mezők történeti kialakulását elemző történeti-szociológiai kutatások kisebb arányban vannak jelen kvantitatív orientációjú tanulmányokhoz képest (lásd pl. Bukodi, 2007; Chan és Golthorpe, 2005; Katz és Gerro, 1998; Lamont, 1992; Peterson, 2005; Sági, 2010 stb.). Ez utóbbiakat főképp a Distinkcióban paradigmatikus igénnyel kifejtett kulturális rétegződési trendek, pl. strukturális homológiák statisztikai vizsgálata motiválja különböző nemzetállami kontextusokban. ${ }^{101}$ Sallaz és Zavisca (2007) hivatkozási indexeket elemző tanulmánya pedig Bourdieu amerikai recepciójáról támasztja alá a fenti állítást.

${ }^{101}$ Erről bővebben lásd Peterson (2005). 


\section{MÓDSZERTAN}

„,Mivel a szociológusokat az objektivitás minél nagyobb fokára való törekvés rendszerint magukkal ragadja, szinte mindig megfeledkeznek arról, hogy az általuk osztályokba sorolt »tárgyak« nem csupán objektive osztályozható gyakorlatokat, hanem az osztályokba sorolás ennél semmivel sem kevésbé objektív eljárásait is kitermelik, amelyek maguk szintén osztályozhatók” (Bourdieu,

2010 [1979]: 49).

\section{1. Jazz-zenész? Tánczenész? „Hétköznapi” zenész? - a konceptualizálással kapcsolatos néhány dilemma}

Mivel a ,jazz-zenész” kategóriája korántsem egyértelmü, röviden összefoglalásra kerül, hogy milyen szempontok szerint konceptualizáltam a kutatás alanyait, akikre a dolgozat folyamán mint jazz-zenészekre, illetve mint jazz-muzsikusokra hivatkozom. A kutatók tudományos orientációjától, valamint a jazz kulturális hierarchiákban betöltött szerepétől függően - nagy presztízsű koncerttermektől, füstös jazz klubokon át a vendáglátós „haknikig” - különböző munkakoncepciók használatosak a jazzt játszó személyekre. Howard Becker a Chicagói Egyetemen írt The Professional Jazz Musician in Chicago [A chicagói profi tánczenész] című szakdolgozatában (Becker, 1949), és az ez alapján készült tanulmányában (Becker, 1951) a tánczenész (dance musician) kifejezést használja. A jazzzenész kifejezés mellett az az érv szól, hogy a vendéglátóhelyeken játszó zenészeknek sokszor képességieket alulmúló tánczenét is kellett játszani, nem csak a magasabb müvészi értéket képviselő (és a laikus közönség számára nehezebben fogyasztható) „tiszta” jazzt. Tiszta jazz-zenét (bonyolultabb harmóniákra épülő ún. jazz sztenderdeket) luxus volt játszani, és sokszor most is az, ami miatt a jazz-zenésznek fellépőhelytől függően esztétikai kompromisszum sorát kell meghoznia.

Becker és Faulkner, a kortárs amerikai kultúraszociológia két elismert - egyébként amatőr jazz-zenész - szerzőjének néhány éve megjelent közös könyvében (Becker és Faulkner, 2009) a Perrenoud-tól átvett musicos kifejezés (2007) mellett kötelezik el magukat, melyet angolra ordinary musician-nek („hétköznapi zenésznek”) fordítanak. Ennek oka esetükben mind a ,jazz-zenész” és a Becker által korábban használt „,tánczenész” fogalmakkal való elégedetlenség volt: míg az előbbi - legalábbis szerintük -, a müvészeti kompromisszumok nélküli jazzjáték luxusát hangsúlyozza túlzottan, a tánczenész kifejezés pedig túlságosan a kommersz, „kiszolgáló”, szórakoztató zenei gyakorlatokra helyezi a hangsúlyt. Kompromisszumként olyan zenészeket hívnak hétköznapi zenészeknek, akik számos stílusban képesek játszani, és a piac elvárásainak megfelelően nem csak a jazz 
müfajában vállalnak fellépést vagy ad hoc jellegü vendéglátós haknit. A hétköznapi zenész fogalmával álláspontjuk szerint a zenészek tág körét kívánják megragadni, és tudatosan azokról írnak, akik jazz-zenész képzettséggel számos müfajban is játszanak a megélhetés érdekében. Definíciójuk tehát „valós” és széles körű zenei/munkavállalói praxisból indul ki, és nem a zenészek által elképzelt ideális kegyelmi állapotból, ahol a művészi önmagvalósítást anyagilag honorálják, és az (értő) közönséget is érdekli a játék.

Kutatásom során azonban a jazz-zenész vagy jazzmuzsikus kifejezéseket használom, mert ugyan a budapesti szcénában is rendkívül sokszínü megélhetési stratégiákat definiálhatunk, egészen a „híg”, „piaci” vagy „állami”"102 jazztől, a kortárs avantgárd szabad zenéig, kutatásom fókuszpontjában a legitim jazz-zenész - interjúelemzések alapján rekonstruált - definíciójának (diszkurzív) konstrukciói, illetve azok zenei kirekesztésben és kooperációban, valamint a presztízsszerzésben betöltött szerepe áll. Az interjúalanyok és jazz-zenészek többsége a vizsgált szcénán belül leginkább a mainstreamhez köthető irányzatokat játszik, oktat és hangszerel. Ezenkívül tudatosan elhatárolják magukat a mainstream képzettséggel nem rendelkező „hétköznapi zenészektől.” A leginkább kommersz, „híg jazzt” játszó zenészek túlnyomó többsége is végzett konzervatóriumot és/vagy zeneakadémiát, akik jellemzően pl. populáris számok hangszerelését, zenei háttérmunkákat végeznek. Tehát saját, specializált, jazzhez köthető tudástőkéjüket kamatoztatják, konvertálják anyagi profikra.

A terminológia tudatos megválasztása a beckeri „művészeti világ” és a bourdieu-iánus „mező” közti episztemológiai különbségekre is utal. A kutatásom során alkalmazott, relacionális bourdieu-i episztemológia a szociológiai tárgykonstrukció során az ágensek (jazz-zenészek) életvilág- és valóságkonstrukcióit (vagyis az osztályozott praxisok osztályozható osztályozó gyakorlatait) hangsúlyozza. Ezzel szemben Beckerék interakcionista nézőpontja - a véleményem szerint elnagyoltan „valósnak” (Becker és Faulkner, 2009) tételezett - zenei gyakorlatokból indul ki. A jazz-zenész által űzött sokszínü tevékenységtípus (hagyományos big band-játék, kamarazenei formációk, haknik, szerzői kompozíciók előadása „felszentelt” fellépőhelyeken stb.) nem teszik a jazz-zenészeket „hétköznapivá”, pl. empirikusan a játszással eltöltött időben mért objektív pénzkeresési struktúrák ellenére sem, nem beszélve a „kommersz” gyakorlatok felé irányuló viszonylagos müfajon belüli stílusirányzatokat átszelő kollektív megvetésről - legalábbis

${ }^{102}$ E kifejezések az interjúalanyaim leíró esztétikai kategóriái, nem zenetudományi terminusok, vagy a saját értékítéletem. 
Magyarországon. Másrészről pedig, a látszólagos objektív nézet, mely abból indul ki „aktuálisan mi történik” (what’s going on) (Becker és Faulkner, 2009: 72), azt kockáztatja, hogy a gazdasági profitszerzések - vagyis a heteronómia alapelve - válnak a klasszifikáló ítéletek kiindulópontjává, annak meghatározásakor mi is történik „valójában”.

\section{2. A „kvázi-etnográfiai” kutatás általános jellemzői}

A 2014 őszétől 2017 őszéig - az 5 „follow up”103 interjút nem számítva - 27, átlagosan másfél óráig tartó interjút készítettem eltérő zenei irányzatot képviselő, generációt és származást tekintve különböző hátterü hangszeres, túlnyomóan férfi jazz-zenészekkel. A 27 interjú közül két interjút 2-3 fös minifókuszcsoportban ${ }^{104}$ valósítottam meg, melynek eredményeképp végül közel 50 órányi manuálisan kódolt interjú átiratát készítettem el, amely az interjúelemzés empirikus anyagát alkotta. A legfiatalabb interjúalany 21 éves, a legidősebb 60 éves volt, az interjúk többségét 25 és 45 éves hangszeres zenészekkel végeztem. A meződinamika megragadása és modellezése, valamint a mezőt alkotó viszonyrendszerek feltárásása érdekében indokolt volt alapvetően kvalitatív módszerek alkalmazása (Ritchie és Lewis, 2003; King, 1994), ezeken belül is a (félig-strukturált) mélyinterjús (King, 1994), valamint a résztvevő megfigyelés (Pickering, 2008) módszerei.

A kvalitatív módszertani szakirodalom megkülönböztet pl. „mélyinterjút”, „magyarázó interjút” (explanatory), félig-strukturált, vagy „strukturáltalan” interjúkat, valamint azok kutatás céljától és kontextusától függő lehetséges alkalmazási módjait (King, 1994: 11). Az itt felsorolt ideáltipikus kategóriák közül az interjúvázlat szerkezetét tekintve a kutatás a félig-strukturált és strukturált interjúk közé esik, azonban, ahogy a fejezetben kifejtem, a több mint három évig tartó kutatás során a megalapozott elmélet módszerének

\footnotetext{
${ }^{103}$ A ,,follow-up” interjú mint egyfajta „kvalitatív panelvizsgálat” azt jelenti, hogy egy adott egyénnel többször is készülnek interjúk hasonló, vagy ugyanazon kérdések alapján. Ezen interjúk előnye a kutatás kontextusában abban állt, hogy egyrészt olyan kérdéseket is volt lehetőség tenni, melyeket a korábbi interjú során idő hiányában nem sikerült, másrészt a már érintett kérdéseket újra, elmélyültebben vizsgálhattam, valamint - és a szakirodalom föleg ezt az aspektust emeli ki - az interjúalany attitüdjeiben, véleményeiben, interpretációiban stb. történő esetleges változásokat is nyomon tudtam követni.

104 E néhány fős „mini-fókuszcsoportok” kialakításánál és véghezvitelénél figyelembe vettem Vicsek Lilla (2006) Fókuszcsoport c. könyvének szociálpszichológiai (csoport)dinamikákról szóló fejezetét (2006: 83124), valamint az általa tartott kvalitatív módszertani órákon tanult egyéb, interjúkészítési technikákkal kapcsolatos szempontokat is (nyitott és zárt kérdések alkalmazásaiból származó előnyök/hátrányok, kérdések struktúrájának összeállítása, a „tölcsértechnika” alkalmazása stb.).
} 
megfelelően (Glaser, 1992; Johnson, 2016: 5) a kutatás hangsúlyai finom változásokon mentek keresztül. Egyes esetekben, hol az egy adott problémakörre fókuszáló féligstrukturált mélyinterjús technika, hol a strukturált - a kutatási szempontok lehető legszélesebb spektrumából merítő, ezzel fordítottan arányosan egyes részkérdéseket felületesebben érintő - technikák domináltak. Jellemzően a kutatás elején szerepeltek hangsúlyosabban olyan kérdések, melyek az eröteret alkotó relációk különböző aspektusaira kérdeztek rá, majd - ahogy egyre inkább elmélyültem a kutatásban és magában a budapesti jazz-életben is - már egyre inkább olyan mélyinterjúk domináltak, ahol egy-egy témakört beszéltünk át részletesen az interjúalannyal, pl. a „romák” megítélést a szcénán belül, vagy a free-mainstream distinkció jelentőségét, annak különböző csoportdinamikával és esztétikai kérdésekkel összefüggő szempontjait. A mellékletben közölt interjúvázlat (1. melléklet) tehát egy fontos viszonyítási pont volt, mely a kutatás kérdésfelvetéseit igyekezte strukturálni, azonban ez nem jelentette azt, hogy minden esetben ragaszkodtam az interjúvázlatban foglalt kérdések sorrendjéhez. ${ }^{105}$ A különböző interjútípusok episztemológiai és módszertani distinkciói alapján sem sorolom a kutatásom során alkalmazott módszerem egyetlen „tiszta” kategóriához - pl. „realista”, „fenomenológiai”, „konstruktivista” interjúk stb. - (King, 1994; Bevan, 2014), noha a kutatás korábban kifejtett elméleti orientáltságánál fogva inkább a fenomenológiai „szociológiai életvilágelemzéshez"106 és a konstruktivista tradícióhoz esik közelebb.

A minden esetben diktafonnal felvett interjúkat és terepnaplók formájában rögzített résztvevő megfigyeléseimet, jelen doktori értekezés elkészítéséig tartó informális beszélgetések, továbbá egy illusztratív jellegü (a jazz-zenészek populációjára nézve a kis minta folytán nem reprezentatív) kérdőíves kutatás $(\mathrm{N}=37)$ is kiegészítette. A fent osztályozott módszereken kívül adatgyüjtésemet a lehető legszélesebb körben próbáltam érvényesíteni: archív (szak)folyóiratok (pl. Jazz Studium 1979-1990) különböző számainak feldolgozása mellett, a Magyar Tudományos Akadémia Zenetudományi Intézetének (MTA-

\footnotetext{
105 Például mikor kevésebb idő állt rendelkezésemre egy adott zenésszel, akkor a (szakértői kiválasztással) kiválasztott zenészt főleg olyan kérdésekről kérdeztem, amikben kifejezetten az ő pozíciójából fontos információkat szerezhettem. Tehát, az interjúkészítésnél is figyelembe vettem a mező szerkezetét, az adott zenész pozícióját az erőtérben és mindazt, amit esetleg korábban nekem az illetőről mondtak.

${ }^{106}$ Az életvilág-elemzéshez (lásd Pfadenhauer, 2005), a bourdieu-i episztemológia (Schütz nyomán) életvilágkonstrukciókat is hangsúlyozó szemlélete (Hadas, 2001) miatt áll közel a kutatásom során alkalmazott módszertan, azonban, ahogy a fejezet további részében kifejtem, a vizsgált összefüggések mezőelmélettel történő magyarázata során egyéb szempontokat is figyelembe veszek.
} 
ZTI) segédmunkatársaként, ahol Maróthy János hagyatékának rendezése volt a volt a fő feladatom, lehetőségem nyílt még nem publikált, jazz-szel kapcsolatos publikációk feldolgozására is, melyek a téma történetiségét árnyalták. Ezen kívül, az interneten és közösségi médiában elérhető filmen rögzített beszélgetések, ${ }^{107}$ heti- és napilapoknak adott interjúk, CD-borítók szimbolikájának interpretálása (lásd pl. 5. 3. alfejezet), valamint egy dokumentumfilm (Ferenczi, 1994) is szélesítette a vizsgálat empirikus fókuszát. A Ser Ádámmal közösen elemzett kérdőíveket az Etűd Konzervatóriumban és a Zeneakadémia Jazz Tanszékén töltettem ki fiatal (16-20 éves) jazz-zenészekkel (Havas és Ser, 2017). Fő kutatási egységeim a jazz-zenészek voltak, rajtuk kívül nem zenész (road, szervező) informátorok is fontos szerepet játszottak az információszerzésben.

A „kvázi-etnográfiai” (Rimmer, 2012) jelzőt azért is használom a kutatásom módszerének leírására, mert noha az interjúelemzés mint fő kutatói módszer dominálja az empirikus elemzéseket, föként a következö, 4. fejezetben, a zenészek interakcióinak geertzi (1976) értelemben vett sürü leírása, az etnográfiai módszer is hangsúlyos szerepet kap a munkámban, ugyancsak a megkülönböztetett szimbolikus különbségtételeket és osztályozott osztályozó és osztályozható praxisokat megragadni törekvő relacionális kutatói szemlélet miatt. Az alfejezet zárásaként álljon egy passzus Szelényi Iván egyik írásából, mely jó analógiája az általam is alkalmazott reflexív módszernek, ami az elöre megfogalmazott kérdésekhez mereven ragaszkodó attitüd helyett a „tereppel' való kapcsolattartást, az etnográfiai szemléletet, összességében elmélet és módszer dialektikájának fontosságát hangsúlyozza:

(...) hogyan képes valaki hinni az emberek átkozott kérdőívkérdésekre adott válaszaiban, ha még egyetlen egyszer sem tett fel személyesen ilyen kérdéseket, és ha még sosem látta, ahogyan a megkérdezett küszködik a kérdéssel, amelyet irreleváns társadalomelméletekböl merítve tettünk fel neki ahelyett, hogy a valós életből indultunk volna ki? Etnográfusok, például Howard Becker tanítványai, mindezt jól tudták: „el kell merülni” a társadalmi körülmények szabta helyzetben, mielőtt megtudhatnánk, melyek a jó kérdések. Etnográfus kollégáimtól (...) tanultam meg, milyen sokat számít, hogy legyenek saját etnográfiai megfigyeléseink (és interjúink). Máskülönben honnan vesszük a bátorságot, hogy azt mondjuk: mi valóban a társadalmi valóságot ragadjuk meg (Szelényi, 2016 [2015]: 125-126)!?

${ }^{107}$ Pl. Csepregi Gyula „JazzBeszéd” c. beszélgetéssorozata a kortárs jazz nagyjaival, köztük roma származású zenészekkel is (pl. Egri Jánossal, Babos Gyulával, Szakcsi Lakatos Bélával stb.) fontos forrásként szolgált a kutatásomhoz. 


\section{3. A mezőelmélet alkalmazása a vizsgált összefüggések magyarázatában}

Visszatérve a Bevezetö fejezet módszertani részt tárgyaló alapgondolatához, mely szerint a mezőelmélet heurisztikus értéke lényegében módszertani (is) - szemben azokkal a hibás antinómiákba ragadt elképzelésekkel, melyek elmélet és módszertan között nemhogy dialektikus viszonyokat nem tételeznek, de különálló „analitikus” kategóriának tekintik azokat $^{108}$-, ebben az alfejezetben a bourdieu-i relacionális episztemológiából származó operacionalizálási eljárásaimat ismertetem. A stratégia lényege tulajdonképpen a fejezet mottójában már benne van: egy olyan (kvalitatív) módszertan kidolgozása a tét, mely az osztályokba sorolt gyakorlatok osztályozó eljárásait képes az objektivitásra törekvő szociológus „nézőpontjába sűríteni” (Bourdieu, 2010 [1979]: 49) és osztályozni a kortárs jazz viszonyrendszerének kontextusában.

E relacionális logika operacionáizálási eljárásának első fázisában a mezőben „működő”, különböző pozíciókkal készített interjúkból rekonstruált, eltérő esztétikai alapállásokból legitimnek tételezett ,jazz-definíciók” univerzumát térképeztem fel. Majd, az interjúkból nyert esztétikai gyakorlattal, kifejezőeszközökkel, tradícióértelmezéssel összefüggő definíciókhoz való viszonyulások terét rekonstruáltam az alapján, hogy a mezőben már a pozíciószerzésekkel kapcsolatban téttel bíró egyes definíciókat hogyan értékelték a jazz-zenészek. Eme absztrakt felvezető után, mielőtt a gyakorlati példákra rátérnék, kifejezetten fontosnak tartom hangsúlyozni, hogy a különböző referenciákon alapuló ,jazz-definíciók” (vagyis, kissé vulgarisan, azon definíciók univerzuma, melyek a „mi számít jazznek?”, „ki mondhatja magát jazz-zenésznek?”, „milyen technikai, esztétikai, stiláris elvek alapján? stb. kérdésekre adnak választ) mind maguktól a jazz-zenészektől származtak, tehát nem a kutató önkényes konstrukciójának eredménye. Így, pl. a főleg roma származású zenészcsaládból származó mainstream zenészek körében elfogadott, sőt esetenként az egyedüli legitim (jazz)zenei megnyilvánulásnak tételezett definíciót ${ }^{109}$

\footnotetext{
${ }^{108}$ A bourdieu-i szociológia értelmezésének egyik kulcsa az olyan - társadalomtudományokban ismerősem csengő - antinómiák meghaladása mint „individuum és társadalom”, „cselekvés és struktúra”, „szubjektivizmus és objektivizmus”, „szabadság és szükség (vagy determináltság)” stb. (Thompson, 1991: 11). Ugyanerről a problémáról általános(abb) tudományszociológiai nézőpontból lásd még Elias (1978) és Bourdieu (1990: 2) észrevételeit.

${ }^{109}$ A mainstream jazz szóban forgó (némileg leegyszerűsített) definíciója a következő három részből tevődik össze: a (1) szvinges lüktetésből, a (2) jazzes frazeálásból (mely egyfajta játékmódra utal) és (3) a jazz sztenderdek ismeretéből (olyan megírt harmóniák melyekre a zenészek improvizálnak a játék során). Bővebben a mainstream és free jazz definíció-értelmezések különbségeiről lásd a következő, 5. fejezet vonatkozó részeit.
} 
„ütköztettem” különböző zenészek elképzelésével arról „mi tekinthető” jazznek. E mainstreamjazz-definícióhoz való viszonyulások, értékítéletek és azok - „dogmatikus” és „reflexív” szélsőséges pozíciói közt húzódó - intenzitása alapján típusokat alkottam. Az intenzitást egyrészt az interjús tapasztalatokra építve, másrészt az alapján interpretáltam, hogy milyen távolságot tartanak egyes zenészektől, vagy stílusoktól. Például megkérdeztem, „kikkel játszanak/játszanának szívesen?” és „miért, vagy miért nem?”. A mainstream/free jazz pólusok közti distinkciók fontos indikátorai voltak a különböző esztétikai alapállásokból konstruált jazz-definíciókhoz tartozó osztályozó ítéletek. A bourdieu-i szociológia nyelvére átültetve tehát, egy a praxisokat meghatározó osztályozó esztétikai elvvel kapcsolatos osztályozási sémák rendszere alapján, rekonstruáltam felismert, és téttel bíró olyan oppozíciókat, mint pl. a „professzionális zenész” és zenei kompetenciákon túlmutató ,autonóm művész” ethosza közti zenei habitus szempontjából téttel bíró releváns különbségtétel. A könnyebb befogadás kedvéért, összefoglalva, e stratégia lényege, abban állt, hogy a zenészek által alkotott definiciókat és értékitéleteket tettem osztályozó itéletek tárgyává az interjúk során, majd ezeket az „osztályozott osztályozó” ítéleteket a típusalkotás céljával rekonstruáltam.

Arra is kíváncsi voltam, hogy a különböző pozíciók „doxája”"110 mennyire kérdőjeleződik meg egyes csoportokon belül és csoportok között az esztétikai különbségtételek során. Amit egy adott pozíciót betöltő zenész magától értetődő, doxikus tapasztalatnak (Bourdieu, 2001) tételez, pl. azzal kapcsolatban mi számít legitim jazz-zenei gyakorlatnak, a magukat free (jazz) zenészként definiálók ortodoxiává vagy dogmává alakítanak át (Bourdieu, 2013: 207). A mainstream jazz képviselöit például esetenként olyan jelzőkkel címkézik, mint „,avítt”, „,megmerevedett”, ,tradicionalista” vagy „technokrata”. ${ }^{111}$ Kutatói stratégiám részét képezte továbbá, annak vizsgálata is, hogy a zenészek a jazz történetének - vagy DeVeaux-t parafrazálva: a jazz „konstruált, cselekményesitett történeteinek"112 - az egyes meghatározó szereplőiről hogyan vélekednek, milyen

110 A különböző pozíciókhoz tartozó „előfeltevéseket” nevezi Bourdieu „doxának” (Bourdieu, 2014: 189), mely más alapvető koncepciók mellett (illúzió, „kollúzió”, autonómia, heteronómia, karizmatikus és intézményes felszentelés stb.) a mezőelmélet fogalmi építményének egyik alapvető terminusa.

111 A „technokrata” kifejezés a szó valós értelmétől eltérően a jazz-zenészek közti szimbolikus megkülönböztetések és státuszharcok relacionális kontextusában pejoratív jelzőként funkcionál, free oldalról nem egy elsajátított (szak)tudás birtokolta autoritást, ill. legitimitást értenek alatta.

${ }^{112} \mathrm{Az}$ egyik fő referencia DeVeaux számára, aki a jazztörténet reflexiót nélkülöző különböző narratíváit tárgyalja Hayden White (1973) „Metahistory” c. monográfiája. Innen a „cselekményesítés” „emplotment” 
szempontok alapján alkotnak ítéletet róluk. Mikor a jazztörténet egyes kanonikus figuráiról, pl. Charlie Parker-ről kérdeztem a zenészeket, elsősorban arra voltam kíváncsi, hogy a különböző pozíciókat betöltő zenészek, milyen esztétikai/legitimációs elvek alapján interpretálják pl. Parkert és másokat. Parker „Bird” kiválasztását a jazztörténetben betöltött szerepe indokolta. Hozzá füződik ugyanis a '40-es években kialakuló, tánczenétől és szórakozástól elhatárolódó modern jazz, a „,bebop”, ami akkoriban hagyományokat felrúgó stiláris-esztétikai újításnak, ha tetszik „forradalomnak” számított: a modern jazz nyelvét ő és zenésztársai teremtették meg. ${ }^{113}$ A Parker-interpretációk - ahogy később utalok rá - az „intellektualizmus és anti-intellektualizmus”, „progresszív és tradicionalista”, „ortodox és újító” stb. ellentétpárokban megragadható zenei habitusok, diszpozíciók kitűnő indikátorai voltak. Ahogy a következő fejezetben részletesen kifejtem, míg a mainstream zenészek a (zenei) nyelv abszolutizálását, a követendő tradíciót „,átják” Parkerben, addig free pozícióból a hangsúlyt a tradíció ellen való lázadás tradíciójára helyezik, arra, hogy Parker akkor „avantgárd volt”, mára pedig „csupán” - teszi hozzá a kutató - a művészi eszközkészlet egy fontos referenciája.

A szimultán esztétikai hierarchia koncepciója ama gyakorlatok alapjául szolgáló osztályozási elvekre épül, amelyeket a zenészek téttel bírónak tekintenek „,a problémák univerzumának és intellektuális igazodási pontok (...) meghatározása” során (Bourdieu, 1993: 176). Bourdieu itt a habitusok kondicionálta sajátos, improvizatív logikát követő ágensek pozíciószerzéseinek néhány meghatározó szempontjaira gondol, ,, amelyeket észben kell tartania annak, aki a játékban akar maradni"114.

terminus is, mely a történetalkotás különböző narratíváit tipizálja (White, 1973: 251-255). Érdekesség, hogy a jazz studies alapvető cikkének szerzője (DeVeaux, 2017 [1991]) csak egyszer hivatkozik Bourdieu-re, azonban fö következtetései a jazz történetének ki- és elsajátítási folyamatairól a bourdieu-i tudományszociológia felfogásba illeszthetők, amennyiben a szerző az objektiváló történettudományi gyakorlatokat objektiválja munkája során.

113 Parker megkerülhetetlen alakja a modern „mainstream” jazz kialukálásának, de olyan más (egyébként zenekaraiban is játszó főleg afroamerikai) zenészek is, mint Miles Davis, Max Roach vagy Dizzy Gillespie.

${ }^{114}$ A terjedelmes mondatban szereplő idézet az angolból - jobb híján - a saját fordításom. A kissé hevenyészett fordításomat érdemes az angollal összevetni, mely így szól ,....) defining the universe of problems, references, intellectual benchmarks (often constituted by the names of its leading figures), concepts in -ism, in short, all that one must have in the back of one's mind in order to be in the game" (Bourdieu, 1993: 176). 


\section{4. Önreflexiós kísérlet: az interjúkészítés és résztvevő megfigyelés körülményei és szempontjai}

A szcéna különböző csoportjaival interjúkat készítő kutatóként a csoporthoz való viszonynak megfelelően periférikus, félperiférikus és mint a belső kör tagja voltam jelen. Mivel az interjúzás - s így a kutatás - eredményeit nagymértékben befolyásolja az interjúkat készítő kutató sajátos pozíciója, „beágyazódása” a szcénába, az (al)fejezetben kísérletet teszek annak bemutatására, hogy milyen etnográfiai elemek egészítették ki a manuálisan kódolt 27 interjút, s ezek milyen jelentőséggel bírnak.

Az interjúzás kezdetekor csupán egy sajátos körre nyílt rálátásom, melyet jellemzően a Jazz Tanszékre járó, vagy frissen végzett zenészek, zenész (gitáros, bőgős, szaxofonos) barátaim alkottak, és akik mint informátorok a szcéna különböző köreihez segítették a személyes hozzáférést. Így egyrészt hólabdamódszerrel (Babbie, 1999), másrészt informátorok ajánlása alapján kerültek kiválasztásra a zenészek, ügyelve arra, hogy a lehető legszínesebb zenei stílusokban alkotó (free jazz, mainstream), intézményekhez köthető (LFZA Jazz Tanszék, Magyar Jazz Szövetség), valamint etnikai és generációs csoportokkal sikerüljön interjút készíteni. A szcénával való „,ismerkedés” során az első fél évben a hólabdamódszer, majd a szakértői kiválasztás dominált, vagyis a kiválasztás elveit a mező szerkezetéről alkotott egyre bővülő ismereteim határozták meg a kiszemelt interjúalanyok válaszadói hajlandóságán kívül. Az interjúszituációkon kívül többször nyílt lehetőség ad hoc jellegü „minifókuszcsoportok” létrehozására is, melyekben jazz-zenészek vitatták meg kutatási kérdéseinket, sokszor - nagy örömömre - megfeledkezve arról, hogy a társalgást a kutató egyébként töretlen, „füllel jegyzetelö” figyelme kíséri.

A több mint 3 év alatt magam is bejártam az utat, amit - Thornton (1995) fogalmát továbbgondolva - (szubkulturális) tőkefelhalmozásnak tekinthetünk. Ennek a sajátos tőkefelhalmozási folyamatnak tapasztalataim alapján két fázisát különböztetem meg. Egyrészt, a szcénával való ismerkedés bevezető szakaszát, mely során az alapvető nemzetközi és hazai referenciákkal ismerkedtem meg és sajátítottam el nyelvi kódokat (pl. a zenei közegben bevett kifejezéseket, szlengeket, zenei szakzsargont), továbbá általános tudást a budapesti jazzéletről. A fellépőhelyek, ${ }^{115}$ személyzet (csaposok, de még biztonsági

115 A Müvészetek Palotája és a Liszt Ferenc Zeneakadémia „felszentelt” intézményein kívül, a Budapest Jazz Club (BJC), a Budapest Music Center (BMC) jazzklubja, az Opus Jazzklub, a Fonó és a Trafó a négy, talán legnagyobb presztízsű fővárosi hely, ahol a műfaj képviseli magát szélesebb közönség előtt. Kisebb, kifejezetten jazzkávézókon kívül, mint a Ráday utcában található Jederman és If kávézók és a szabadabb zenei 
őrök és az ún. „road-ok”"116 is) és a legkülönbözőbb stílust képviselő muzsikosok ismerete legalább olyan szinten, hogy milyen hangszeren, mely formációban és kikkel játszanak, nagyban növelte a kutatói pozícióm elfogadását, és bennfentességet, bizalmat kölcsönzött az időben és tematikusan strukturált interjúk légkörének. A következő, előrehaladottabb szakasznak azt nevezem, amikor a jazzszcénán belüli különböző csoportok sajátosságairól is információt szereztem, melyet tudatosan használtam fel annak érdekében, hogy ne csak elfogadják, de téttel birónak is tekintsék a kutatást, azon belül a mellékletben is közölt interjúvázlatban foglalt kérdéseimet (1. melléklet). E belső(s) információknak kifejezetten nagy hasznát vettem, amikor különböző okoknál fogva a tervezett egy-másfél óra helyett kevesebb idő állt rendelkezésre, pl. koncertek előtt vagy koncertek szüneteiben. A szubtilisabb, esztétikai kérdéseket és zenészcsoportok közti viszonyrendszereket érintő finomabb ismeretek elsajátításának gyakorlati jelentősége abban állt, hogy nem csupán általános kutatási szempontjaim alapján (megélhetés, stílusok közti különbségek, a „roma jazz” esztétikai-technikai sajátosságai stb.), de az egyes körök, sőt egyes zenészek számára egzisztenciális téttel bíró kérdésekről is autentikus módon tudtam beszélgetést kezdeményezni, ami sokkal inkább a jazzszcéna viszonyait ismerő „belsős” kérdező pozícióját jelentette.

Egy roma származású kulcsinformátor egyenesen akkor tekintett egyenrangú beszélgetőpartnerének, mikor tételesen tudtam a (roma) zenészek rokonsági viszonyait, sőt e rokonsági és baráti kapcsolatok rendszerváltás előtti gyökereit! A hónapok során pedig ugyanaz a nagy köztiszteletnek örvendő, a szakmában évtizedek óta tevékenykedő, a jazzzenészekhez rokoni szálakkal is kötődő személy már szemrehányást tett, ha kihagytam egy koncertet. E kulcsinformátorral való ismeretség dinamizmusa jól szemlélteti a zeneileg kvázi dilettáns (hobbigitáros) szociológus emancipációs történetét; avagy hogyan lett egy a különböző koncerteken fel-felbukkanó, sejtelmesen jegyzetelő, fel nem ismert árnyból egy felismert valaki, akinek bizonyos körök megnyílnak, akit befogadnak, sőt egyesek azóta barátjuknak tekintenek.

müfajoknak, a szabad zenének és free jazznek is alkalmanként teret adó Lumen Kávézót, Kék Ló bárt, Mika Tivadar Mulatót, Lámpást és Aurorát, Kisüzemet, Fekete kutyát, Szimplát és újabban a Három Hollót érdemes megemlíteni. Ezenkívül számos étteremben és kávézóban van jelen a müfaj, teret adva - leginkább háttérzenét nyújtó - ad hoc formációknak, hakniknak (Központ Kávéház, Hadik Étterem, Szatyor stb.). A fenti felsorolás nem teljes, és a kutatás kezdete óta természetesen változott a felhozatal a fellépőhelyek tekintetében is.

${ }^{116}$ Szállító személyzetnek fordíthatjuk, ám vannak akik a „technikust” preferálják annak magasabb presztízsű áthallásai miatt. 
Fontos még megemlíteni, hogy a kutatás során fokozatosan felhalmozott „tudástőkét” (a szcénáról, formációkról, zenészekről való ismereteket) mint koncertszervező is felhasználtam: 2016-ban a Központ Kávéházban szerveztem (a tavaszi szezonban) duókoncerteket, ugyanez év őszétől 2017 nyár közepéig pedig a Hadik Kávéház, és részben a hozzá tartozó Szatyor jazz-programjaiért voltam felelős. ${ }^{117} \mathrm{E}$ „kapuöri” pozíciót, melyet a szervezés jelentett önreflexíven kezeltem (nevezetesen a zenészekkel való interakciókat ennek fényében interpretáltam), másrészt pedig maximálisan kihasználtam az információszerzés során. A résztvevő megfigyelés módszerét különböző aspektusokból tárgyaló szakirodalmak (pl. Nightingale, 2008; Jorgensen, 1989; Platt, 1983) különbséget tesznek különböző kutatói pozíciók között annak alapján is, hogy a kutatott „terepen” a kutató mennyire passzív vagy aktív szerepet tölt be, hangsúlyozva a közelség/távolságtartás modalitásaiból származó előnyöket és hátrányokat. A kulcs - úgy gondolom - itt is az önreflexióban, illetve a kutatott csoportok és egyének nézőpontjaival való azonosulás képességében van. E kvalitásokról, azonban egyedül az empirikus elemzések (szakértői) megítélései adhatnak számot, nem elegáns ugyanis kutatóként az adott közeg szimbolikus és nyelvi kódjaiban való járatosságot (túl)hangsúlyozni, sem a különböző nézőpontokat összesürítő, „objektív” totális tekintet birtoklójaként tetszelegni, amit Bourdieu egyébként a „tudományos reflexivitással szemben álló posztmodern antropológiára jellemző narcisztikus reflexivitás" (Bourdieu, 2003: 281) ${ }^{118}$ kategóriával illet - hozzátehetnénk, okkal. Összességében a szervezői pozíció kölcsönözte bennfentesség olyan előnyöket jelentett, melyekről a kutatás kezdete során ,álmodni” sem mertem: azon túl, hogy bizonyos zenészekkel napi, ill. rendszeres kapcsolatban voltam, az általam szervezett koncerteken minden alkalommal (hónapokon keresztül a Hadik Kávéházban pl. minden egyes hétfőn!) jelen voltam, ahol alapvetően a vendéglátózással kapcsolatos attitüdöket és a közönséggel kapcsolatos dinamizmusokat volt lehetőségem közelről tanulmányozni.

\section{5. Jazz és dzsender}

A fentiek kapcsán ejtenék néhány szót az erőteljesen maszkulin, hangszerközpontú „,pool”ról, vagy kutatói mintáról. Alapvetően három dzsenderviszonyokkal kapcsolatos kérdéskört emelnék ki a kutatás kontextusában, melyeket a munkámban, annak eltérő fókusza miatt csak fölületesen érintettem. A kortárs magyar jazz történetileg kialakult férfiuralmi

\footnotetext{
${ }^{117}$ A fent felsorolt helyek mellett szerveztem még koncerteket a Magvető Kávéházba és a Fonóba is.

118 Szintén saját fordításom a posztumusz publikált, Loic Wacquant fordította angol cikkből.
} 
logikájának feltárását, a (férfi) kérdező sajátos kutatói pozíciójára történő reflexiót, valamint a jazz és klasszikus zene közti nemek eloszlásával kapcsolatos különbégek vizsgálatát. A szcéna férfiuralmi logikájának elemzése és a klasszikus zenével történő összehasonlítás a társadalmi nemek szempontjából önmagában is izgalmas dolgozatok témáját képezhetnék, ezért a következőkben igyekszem ezekre reflektálni, még ha az empirikus elemzés során egyéb szempontok domináltak is munkámban, pl. az etnikum és az esztétikai különbségtételek összefüggései vagy a megélhetési stratégiák.

Ahogy Barna (2017) is kifejti a Lo-Fi szcénáról írt tanulmányában, a populáris zenei szcénákban a feminista törekvések ellenére is müfajokat, stílusokat és földrajzi régiókat átívelő tendenciózus férfiuralom tapasztalható (Barna, 2017: 51, lásd még Straw, 1977). A férfiközpontúság nem csak a nemek arányaiban érhetö tetten, de a zeneipar hatalmi pozícióit is tipikusan férfiak töltik be, továbbá a társadalmi nemekkel kapcsolatos sztereotípiák a kirekesztés meghatározó instrumentumaként funkcionálnak, sokszor maguk a női zenészek interiorizálják az ízlés és értékmonopóliummal rendelkező férfiak esetenként szexista és degradáló értékítéleteit. Barna (2017) populáris zenei szcénákról tett észrevételeivel egybehangzóan, a nők, néhány kivételtől eltekintve a magyar jazzszcénában is mint énekesek voltak jelen, akik közt a státuszkülönbségeket eröteljesen a zenei képzettség határozta meg, az, hogy mennyire vannak tisztában a jazzelmélettel, a hangszereléssel és mennyire tudják - a zenészek szavával élve - egy szám közben „mi történik a zenében”, vagyis éppen milyen hangnemben, mely akkordok szólalnak meg és milyen kvázi-objektív improvizálási lehetőségekre ad lehetőséget.

Az interjúkat készítő kutató pozíciója kapcsán jogosan merül fel a kérdés, hogy vajon mennyiben befolyásolta, hogy férfiként kérdeztem föként férfi zenészeket, vagyis az információhoz való hozzáférésem mennyiben torzította, illetve segít(h)ette elő a kérdező (társadalmi) neme. A kérdésre azért nehéz válaszolni, mert nem csak a majd 30 interjút kell átértékelnem, de a közeggel való viszonyomat is mint koncertre járó, a jazzt kifejezetten kedvelö férfi társadalomtudós, akinek személyes kapcsolatai révén is hozzáférése volt a zenészek bizonyos köreihez. Pusztán az interjúzás tekintetében a társadalmi nemet önmagában nem tekintem az interjúk kimenetelét egyértelmüen pozitív (pl. közlékenység, a kérdésekre való nyitottság) vagy negatív (pl. ignorancia, zárkózottság, lekezelés) értelemben befolyásoló tényezőnek, mert összességében, a három intenzív év alatt azt tapasztaltam, hogy az interjúalanyokból történő alapos felkészülés, a szcéna ismerete, a zenészekkel ápolt személyes kapcsolatok természete, a szakzsargon ismerete jóval nagyobb hatással volt az interjúk kimenetelére, mint a férfimivoltból fakadó cinkosság kölcsönözte kitárulkozás az 
interjúalanyok részéről, - illetve az ebböl való profitálás. Korábban említettem például, hogy volt olyan informátor, aki addig nem vett komolyan, amíg alaposan nem ismertem bizonyos jazz-zenészek családi viszonyait. Itt említeném meg azt is, hogy a hangszeren nem, vagy csak amatőr szinten játszó társadalomtudós alapvetően a „messziről jött ember” értelmiségi pozíciójában találja magát, mely viszonylag távol van vizsgált közeg sajátos normarendszertől és nyelvi kódjaitól, így a kérdező és interjúalanyok közti távolság leküzdése, egyfajta bizalmi légkör kialakítása kérdező és válaszadó közt a szcéna tagjai számára téttel bíró kérdések ismeretéből, valamint annak hatásos kommunikációjából fakad meglátásom szerint. ${ }^{119}$

Mivel vokális duókoncerteket szerveztem, számos alkalmam volt énekesnőkkel a kutatási kérdéseimről és saját női pozíciójukról beszélgetéseket folytatni. A társadalmi nemek szerepét a kulturális felszentelésben és státusszerzésben (lásd Venrooij és Schmutz, 2010) nem vizsgáltam részletesen, azonban kutatásom során reflexíven kezeltem, ez volt a legtöbb, amit tehettem a rendelkezésemre álló idő és (anyagi) erőforrások birtokában, valamint a mező szerkezetét feltáró kutatási kérdéseim szempontjából is.

\section{6. Az interjúvázlatról}

A nagyjából másfél órásra tervezett interjút szervező interjúvázlat három fő strukturális egységből állt. Az első szekcióban a hangsúly az intézményes zenei tanulmányokon és a Zeneakadémia kapcsolatszerzésben betöltött szerepén volt, valamint a fontosabb zenei referenciák kérdésén, melyek a zenei identitások szerves részét képezték. A második rész a jam sessionök és a muzsikusok közti kollektív interakció kérdéseit járta körül. Ez utóbbi kiemelten fontosnak bizonyult, mert a jam sessionök külsöre demokratikus (Becker, 2010) világa mögött hierarchikus viszonyok húzódnak meg, s e téma a kutatásom fontos tárgyát alkotta. Végül, az utolsó szekcióban, mikorra már - ha szerencsém volt - kialakult egyfajta kölcsönös bizalom kutató és interjúalany közt, a szcénát megosztó törésvonalakra kérdeztem rá. A legfontosabb rétegképző dimenziók a „stílus”, „generáció”, „etnikum”, „befutottság”,

\footnotetext{
${ }^{119}$ Azt sajnos nem tudom megítélni - noha kifejezetten érdekelne -, hogy ugyanebben a közegben éveket eltöltő női kutató hogyan reflektálna kutatói pozíciójára, mennyire tapasztalna szexista megnyilvánulásokat, és adott (interjú)szituációkban a kutatási kérdések függvényében vajon előnyére tudná-e fordítani a maszkulin közeg egyes képviselőinek dzsendersztereotíp megnyilvánulásait, vagy fordítva, mennyire jelentene előnyt a kérdező női pozíciója (pl. énekesnőkkel folytatott beszélgetések során a dzsenderalapú kirekesztés témakörében).
} 
„jazz és klasszikus zene viszonya”, „elismertség”, „nők helyzetével kapcsolatos attitüdök”, „presztízs”, valamint a „megélhetés és müvészi önmegvalósítás lehetőségeinek különbözőségeiböl származó feszültségek és konfliktusok" voltak. A kutatás jellegéböl fakadó módszertani problémákat (részrehajlás, egyoldalúság) egyrészt a kiválasztás fent leírt szakértői logikája ellensúlyozta, másrészt az alkalmazott elemzési módszer maga, mely a következö interjúrészletekből is látszó, a szcénában jelenlévő párhuzamos, sokszor ellentétes valóságkonstrukciókra tudatosan reflektált:

Nem nagyon vannak átfedések, (...) mindenki szidja a másikat, ezáltal igazolja magát, ezért nem tudok ebbe belemenni, nem tudom az igazságot.

Ezek az emberek nem kommunikálnak, ez a magyar benne, hibásak a képek egymásról, teljesen, prekoncepciók és előítéletek vezérelnek minden egyes gondolatot.

A kulturális fogyasztással kapcsolatos szakirodalom módszertani tanácsait megszívlelve (Bourdieu, 1984; Peterson, 2005) nem csak a preferenciákról szerepeltek kérdések, de a diszpreferenciákról is, vagyis arról, hogy a kérdezett muzsikusok milyen irányzatokkal és kikkel szemben azonosítják magukat. ${ }^{120}$ Így pontosabb képet kaphattunk arról, hogy az eltérő presztízzsel rendelkező zenészek mennyire alkotnak konszonáns képet a szcénáról, és melyek a szcénát megosztó vitatott kérdések. Egyúttal a konfliktusos területek feltárására is lehetöség nyílt, melyekhez a szcéna különböző pozíciói (eltérő generációs és gazdasági háttérrel bíró, különböző stílusokhoz köthető zenészek) különböző előjellel és eltérő intenzitással, de feltétlen viszonyulnak. Leegyszerüsítve, kutatásom a jazzszcéna szerkezetét a különböző pozíciók „viszonyulásainak” logikája alapján igyekszik megragadni és modellezni. Összességében a budapesti jazzszcéna szerkezetének modellezése során kevésbé volt hangsúlyos elem a tartalmi állítások ,igazságának” értékelése (pl.: ki számít jó zenésznek, a free zenészek hangszertudása, a mainstream jazzt játszó roma zenészek ízlésének megitélése, stb.), mint a különbözö viszonyulások és percepciók terének feltérképezése. Így az egymásról alkotott „hibás képek” a megkérdezett zenészek értékítéleteivel összefüggéseiben értelmezhetők, melyekböl kirajzolódnak a szcéna dinamizmusát és szerkezetét alkotó főbb oppozíciók. Mivel egy-egy azonosított kör megitélését nagyban befolyásolhatja a csoporthoz tartozó egy-egy ember habitusa, akár a valós zenei kvalitásoktól teljesen függetlenül - „annyira kicsi a közeg, hogy egy-egy

${ }^{120}$ Mert ,izlés dolgában ... minden elhatározás tagadás; az izlés talán elsősorban és leginkább ellenszenv”. A fordítás Peterson (2005: 264) alapján az angol szövegböl saját: H. Á. 
személyiség sokat árt" - igyekeztem valamely szóban forgó csoportról több forrásból is információt nyerni, hogy megtudjam, valóban az adott kör leírásáról van szó, vagy az adott kör egy tagjának provokatív, extrém megnyilvánulásáról.

\section{7. A kérdő́ves kutatás jellemzői}

Az alapvetően kvalitatív kutatást az interjúk tanulságai alapján a Zeneakadémia Jazz Tanszékének hallgatóival készített kérdőíves vizsgálattal is kiegészítettem, melyet 2016. március-áprilisban kérdeztem le és Ser Ádámmal közösen elemeztünk. ${ }^{121}$ Célunk ezzel elsősorban oksági összefüggések feltárása helyett a jazzszcénába belépő vagy belépni szándékozó fiatal zenészek attitüdjeinek megismerése volt. Bár a kérdőíves technika nem teszi lehetővé, hogy az interjúzáshoz hasonló mélységekig megismerjük a hallgatók véleményét, de jóval több zenésztől tudtunk adatot szerezni, noha - források híján - így sem reprezentatív módon. Az interjúvázlat tematikája alapján készült kérdöíves felvétel során többek közt arra kerestük a választ, hogy a hallgatók, a maguk sajátos, frissen belépő pozíciójukból, vajon hasonlóan látják-e a jazztársadalom helyzetét, mint a kvalitatív vizsgálatban részt vett profi zenészek. ${ }^{122}$ Emellett arra is kíváncsiak voltunk, hogy milyen társadalmi háttérrel bírnak azok a kérdezettek, akik a jazz-zenész pályát választják. A nemzetközi irodalomból megtudhattuk, hogy Nagy-Britanniában rendelkezik a jazz egyfajta osztálydimenzióval, azaz csak a módosabb középosztálybeli családok gyermekei engedhetik meg maguknak, hogy ezt a pályát válasszák, Amerikában viszont nem tapasztalható ez az erőteljesen „középosztályos” jelenség. A kérdőívben foglalt témafelvetéseink és a kapott válaszok reményeink szerint kellő hátteret biztosítanak a kvalitatív mélyelemzések (Havas, 2017a) kontextualizálásához.

\footnotetext{
${ }^{121}$ A lehetőségért külön köszönet illeti Binder Károly dékánt és Friedrich Károly tanár urat.

${ }^{122}$ Ez a határ természetesen több esetben elmosódik; aktív, profi formációk tagjai közül is járnak a Tanszakra, pl. Párniczky András vagy Bille Gergő és mások.
} 


\title{
4. KÜLÖNBSÉGTÉTELEK RENDSZERE A MAINSTREAM - FREE JAZZ DISTINKCIÓBAN
}

\author{
„(...) Egy versnek nem jelentenie kell, de léteznie; ha meg kell kérdezned mi a jazz, \\ sohasem fogod megtudni." \\ Clifford Geertz ${ }^{123}$
}

\subsection{Bevezetés}

„Sértettség”, „harag”, „görcsök”, „frusztráció”, „posvány”, „klikkesedés”, „átjárhatatlanság”, „önigazolás”, „sokrétüség”, „elöítélet”, „kompenzálás”, „elégedetlenség” - néhány, nagyrészt negatív visszatérő jelző, mellyel a különböző generációba tartozó és stílusokat képviselő interjúalanyok jellemezték magyar jazz színtért. A jazz szcénával kapcsolatos negatív felhangok az elemzés részét nem képező egyéni motívumokon kívül, a magyar jazz történeti fejlödésének sajátosságával, a megélhetési stratégiák és karrierutak alakulásával, a pozicionális piaci és intézményes körülményekkel, valamint a zenészek körében „klikknek” vagy „szektának” nevezett csoportok közti esztétikai ellentétekkel vannak összefüggésben. A fejezet során a jazzszcéna mint zenei gyakorlatokat strukturáló bináris oppozíciók kifeszítette erőtér szerkezetét vizsgálom, különös tekintettel a free és mainstream jazz megkülönböztetés esztétikai alapelvekkel, ideológiákkal és habitusokkal összefüggő szempontjaira a bourdieu-i mezőkonstrukció alkalmazásával. ${ }^{124}$

A fejezet során a 2014 őszén induló, elsősorban kvalitatív interjúkra és önreflexív megfigyelésekre épülő szociológiai jazzkutatás egyik legsajátosabb és leginkább releváns problémakörének értelmezésére vállalkozom: a free és mainstream jazz oppozíció jelentőségének részletes elemzésére a budapesti jazzszcéna rétegződésében. Az erőtér általános bemutatását, a két irányzat müfajtörténeti kontextualizálása követi, majd a jazz színtér rétegződését erőteljesen meghatározó különbségtételrendszer különböző zenei habitussal, esztétikai elvekkel és ideológiákkal, társadalmi beágyazódással és megélhetési stratégiákkal összefüggő jelentéstartalmait vizsgálom. Az empirikus részek során a mellett érvelek, hogy az alapoppozíció legfontosabb aspektusait összegző, 1. táblázatban foglalt

\footnotetext{
${ }^{123}$ A Louis Armstrongnak tulajdonított szállóigét Geertz nyomán (1976:1) a saját fordításomban közlöm: H.Á. ${ }^{124}$ A fejezet korábban publikált munkám (Havas, 2017a) átdolgozott verziója.
} 
ellentétpárok kreálta értelmezési mező rendszerszinten képes megragadni a bináris oppozíciók strukturálta budapesti jazz szcénát átható legitimitásharcok fô tétjeit és dinamizmusát.

A bourdieu-i mezőkonstrukció modelljének alkalmazása és egyúttal differenciálása során kutatásom azokhoz a legújabb kísérletekhez csatlakozik, melyek a mezőelemzést a zene szférájára terjesztik ki (Prior, 2008, 2013; Rimmer, 2012; Varriale, 2015; Lopes, 2000; DeBoise, 2016). A címben szereplő rendszert alkotó mezőt strukturáló oppozíciók kvalitatív elemzése során továbbá szimultán esztétikai hierarchizálódás koncepcióval kísérlem meg megragadni a pozíció- és presztízsszerzések logikáját, külön hangsúlyt fektetve a különböző referenciákra (bartóki hagyományok, népzene, mainstream jazz, free jazz, szabad improvizációs és kortárs avantgárd zene), amelyek a zenészek identitásában és önértékelésében meghatározó szerepet töltöttek be. E koncepció azt hangsúlyozza, hogy a presztízs konstrukciójában a vizsgált erőtér szerkezeti sajátosságainak megfelelően, a fejezetben részletesen vizsgált, párhuzamos hierarchizálódási elv, vagy rendszer játszik döntő szerepet, és nem az autonómia és heteronómia - a művészet és pénz - strukturáló alapelveinek oppozíciója. A későbbiekben kifejtett fó érveim a fogalom érvényességét illetően; a két esztétikát ideologikus módon képviselő csoportok egymástól való (szinte) teljes elzárkózása, a köreikbe történő magasan kodifikált, eltérő elveken alapuló belépési adó, és a kommersz jazz elítélése mindkét fő csoport részéről. Állításom szerint, a szcéna gazdasági és szimbolikus profitok dimenziójában történő elemzése átsiklana a pozíciószerzéseket leginkább meghatározó dimenzión, mely meglátásom szerint a két, oppozíciós logika mentén szerveződő al-erőtér dichotómiájában foglalt strukturált ellentétekben ölt testet.

A fejezet 4 föbb hátrányát tartom közlésre érdemesnek. A vizsgált pozíciók történeti kialakulását terjedelem és erőforrások hiányában itt mellőzzöm, csak a már meglévő történeti-szociológiai munkákat emelem be (pl. Havadi, 2011) az elemzés horizontjába, főképp az egyes zenéscsoportok identitásképző zenei referenciái és a történeti háttér árnyalása kapcsán. Az elemzés során az egyik szélsőséghez sem sorolható köztes pozíciók valamelyest háttérbe szorulnak, mert a bináris oppozíciók kifeszítette erőtér van döntő hatással a pozíciószerzésekre. A zenészek pozíciószerzéseinek komplex, intézményekhez köthető dimenzióját, beleértve a képzőhelyek struktúráját és hierarchiáját, a fellépőhelyek tipizálását és az online médiareprezentációt az alapdichotómia tárgyalása során csak érintőlegesen kezelem. Végül, az egyes irányzatokhoz tartozó zenészek tőkekombinációinak szerkezetét is az elvárhatónál felületesebben érintem. Ez utóbbinak az interjúkészítéssel 
kapcsolatos praktikus okai vannak. A családi, társadalmi háttérrel kapcsolatos kérdések elmélyült tárgyalására idő hiányában ( 30 perctől másfél, két óra/interjú) nem minden esetben volt lehetőség. Az elemzés fenti, reflexíven kezelt hátrányaival együtt is reményei szerint érvényes képet nyújt a színtér rétegződésének lényegét alkotó ki- és elsajátítási harcok tétjeiröl és természetéről.

\section{2. Centrum - periféria viszonyok területi és szimbolikus dimenziói}

Zene és közösség viszonyait különböző szempontok szerint teoretizáló, sokszor ellentmondásokkal terhelt (Hesmondhalgh, 2005) rivalizáló kultúraszociológiai koncepciók (mező, művészeti világ, szcéna, szubkultúra, neotörzs, millió, müfaj stb.) alkalmazási lehetőségeit az értekezés elméleti fejezetében közöltem. A 2. fejezet tanulságai alapján, a magyar színtér mélyvalóságára nagyon is jellemző pozíciók ki- és elsajátításáért vívott harcok logikáját leginkább megvilágító mezőelmélet fogalmi hálójára támaszkodom az elemzés során (Bourdieu 1993; Maanen, 2005), kiegészítve az empirikus szubkultúra- és szcénakutatások (pl. Bryson, 1996; Hodkinson, 2002; Kahn-Harris, 2007) tapasztalati nyomán létrejött olyan koncepciókkal - pl. „szimbolikus kirekesztés” (Bryson, 1996: 887) -, melyek a vizsgált színtér rétegződésével kapcsolatban is relevanciával bírnak. A szcéna viszonyait tárgyaló elemzés során a „mező”, „,erőtér”, ,„színtér” és „,szcéna” koncepciókat is alkalmazom.

Kis túlzással - és szerénytelenséggel - magyarországi jazzkutatásnak is betudható a munkám, mert a zeneiskolai hálózat országos kiterjedése ellenére Kodály országában a fesztiváloktól eltekintve szinte csak budapesti jazzszcénáról beszélhetünk. Számos interjúalany maga is Pécsről, Miskolcról és más magyar és határon túli városok zeneiskoláiból érkezett a fővárosba, ahol szinte kivétel nélkül a felsőfokú képzést jelentő Jazz Tanszékre (tanszakra) jelentkeztek. A hazai és nemzetközi hírü muzsikusok is túlnyomó részt a fővárosban élnek. Az interjúalanyok az erőteret tipikusan „belterjesnek” írják le, mely „Budapest táblákkal van szegélyezve”, utalva arra, hogy intenzív jazzélet a fövárosban van. A színtér rétegződését megragadó kérdésem kapcsán (hol húzhatók meg a határok, kik tartoznak bele, vannak-e átjárások a szcénát alkotó csoportok közt) abszolút konszenzust a Jazz és Klasszikus Tanszék közti infrastruktúrában és elhelyezkedésben is testet öltő alárendelt viszonyon, valamint Budapest dominanciáján túl, magának a közösségnek az erősen szegmentált, „klikkekbe tömörült”, konfliktusokkal átszőtt természetével kapcsolatban tapasztaltam. 
Számszerüsítve, a szcénát párszáz fős keménymag alkotja, ${ }^{125}$ melynek tagjai kölcsönösen (fel)ismerik egymást és saját, vagy ad hoc (hakni)formációkkal ${ }^{126}$ legalább havonta fellépnek néhány alkalommal az eltérő presztízzsel bíró fellépőhelyek valamelyikén. A rendszeresen fellépő centrális ágenseket leszámítva, az erőtér perifériáját alkotó zenészek már egy jóval kevésbé megfogható kört alkotnak. A „,peremhez” tartoznak tipikusan pl. az „old timer”, big band zenészek közül azok, akik nem játszanak kisebb, aktív jazz formációkban és azok a - többnyire szakképesítéssel (konzervatórium, zeneakadémia) rendelkező - zenészek, akik főleg populárisabb és alkalmazott müfajokban tevékenykednek. A big band formációk (zenekarvezetőtől, zenészektől, és repertoártól függően), a „roma jazz” mint sajátos „stílus” a magyar jazzen belül, és főként a free jazz megítélése tipikus „vitás területeknek” számítanak a jazz-zenészek körében. A szcénában jelenlévő klasszifikációs sémák és legitimációs konfliktusok diszkurzív konstrukcióinak elemzése előtt, azonban az alapdichotómia, a mainstream és free jazz főbb műfaji jellemzőjét mutatom be.

\section{3. Múfajtörténeti lábjegyzet}

Mainstream ${ }^{127}$ jazznek a '40-es évekre kialakuló irányzatot nevezzük, mely leginkább a müfajt akkor forradalmasító Charlie Parkerhez és holdudvarába tartozó zenészekhez köthető. Parker rövid munkásságában forrott ki ugyanis paradigmaszerüen a '40-es évek második felére teret nyerő bebop stílus, ${ }^{128}$ melynek ismerete és elsajátítása azóta a legtöbb

125 A BMC jazz-zenei adatbázisában 701 fő szerepel egészen a 1910-es születésűektől kezdve, azonban adminisztratív okok folytán számos zenészt - közülük néhány interjúalanyt - nem találni benne, több zenész pedig már nem tekinthető aktívnak, vagy már nem él. Az interjúk alapján készült hozzávetőlegesen 200-as becslés egybecseng a megkérdezett zenészek percepciójával is, mely fontosabb információ a kutatás szempontjából, mint a zenei adatbázis klasszifikációs elvei nyomán létrejött számadat.

126 Képzett zenészek alkalmi formációja, jellemzően rendezvényeken, bárókban és éttermekben zenélést nevezik hakni, vagy session zenélésnek. Ez is lehet nagyon magas színvonalú.

${ }^{127}$ A kutatás tapasztalatai alapján a jazz-zenészek körében leginkább használatos kifejezés a mainstream jazz angol terminus, továbbá használatosak még a „középutas”, „fősodratú”, „sztenderdezős”, „tradicionális”, „Szvinges”, „bebop” kifejezések is.

${ }^{128}$ Unalomig ismételt, jazztudorok sokszor egymásnak ellentmondó zeneesztétikai jellemzései helyett (alterált akkordok használata, komplex harmóniák és akkordvezetés, virtuozitás, hangnem és tempó váltakozása stb.) (DeVeaux, 1999) Geertz fenti intelmeinek szellemében ajánlatos nem (csak) verbális úton közelíteni a stílushoz, és belehallgatni a „kötelező” alapokba; a vonatkozó korszakban pl. Charlie Parker, Miles Davis vagy Dizzy Gillespie életmüvébe. 
jazzt oktató intézményben kötelező alapként szerepel. Akik később el-el is szakadtak a bebop stílustól, újításukat sokszor a mainstream jazz nyelvét adó bebop és szving kanonizált szabályaival összefüggésben határozták meg. ${ }^{129}$ Leegyszerüsítve - és e kvalitatív elemzést tekintve ez elegendő is - egy alapvetően az afroamerikaiakhoz köthető zenei nyelvről, előadásmódról van szó, mely a '40-es évek modernista fordulatát követően egyre inkább eltávolodott a populáris tánczenétől, és a big band felállással párhuzamosan bonyolultabb harmóniákra improvizáló kisebb formációk (,jazz combo”) jöttek létre. A szórakoztató, piaci igényekkel és a populáris zeneipartól való részleges szakítás során az '50-es évek második felétől alakult ki, és intézményesedett a Lopes (2000) által modernjazzparadigmának nevezett zenei áramlat (lásd. 2.5. fejezet).

Az '50-es évek végére kialakuló amerikai free jazz mozgalom már pont ez ellen a paradigma, esztétika, vagy nyelv (értsd: „bebop”) ellen lázadt (Rechniewski, 2008: 22), reformálta meg, stílusjegyeinek tudatos dekonstruálásával ${ }^{130}$ vagy sok esetben továbbvitelével. A free jazznek - ahogy a mainstreamnek is - számos leágazása van; számunkra ugyancsak elégséges az amerikai és európai főcsapások ${ }^{131}$ és azok regionális és nemzetállami sajátosságokinak említése. ${ }^{132}$ Free és mainstream jazzen túl, a szabad zene kifejezés is magyarázatra szorul, mert a free jazzt alkotó zenészek többsége „szabadzenésznek” is hívja magát. A szcénában uralkodó közmegegyezés szerint a szabadzenészek alatt a mainstream zenei kánonnal tudatosan szembenálló kört tekintem, akik free jazz mellett a kortárs klasszikus zenéhez közelebb álló, teljesen szabad zenét is

${ }^{129}$ A free jazz ikon, Ornette Coleman albumcímei is tekinthetők ilyen kiáltványoknak „The Shape of Jazz to Come” (1959), vagy „Free Jazz” (1961), - igaz, az előbbi jobbára a kiadó nyomására kapta programadó címét. ${ }^{130}$ A 2018-ban elhunyt Cecil Taylor amerikai pionír free jazz zongorista gyászjelentésének címe a New York Times hasábjain (Ratliff, 2018) is árulkodik a free jazz mozgalom és mainstream jazz viszonyáról: „Cecil Taylor zongorista, aki szembeszállt az ortodox jazz-szel, 89 éves korában meghalt” („Cecil Taylor, Pianist Who Defied Jazz Orthodoxy, Is Dead at 89").

${ }^{131}$ Ide tartoznak Lenny Tristano, Ornette Coleman, Thelonious Monk, Charles Mingus, Albert Ayler, a késői John Coltrane, Pharoah Sanders vagy Sun Ra. Európában az ECM és FMP kiadók ernyője alá tartozó ikonikus európai free jazz előadók, pl.: Peter Brötzmann, Peter Kowald vagy Alexander von Schlippenbach és zenésztársaik tartoznak.

${ }^{132}$ Magyarországon tipikusan a népzene, cigányzene, a nemzetközi és magyar - elsősorban Bartók - klasszikus zene és különböző jazz tradíciók fúzióját említhetjük mint sajátos „nemzeti specifikumot”. A szimultán hierarchia lényegi aspektusa ezen legitimációs elvek és tradíciók sokszínűsége, mely az Amerikában „őshonos” jazz-szel kapcsolatos analógiák mellett és azokon túl (pl. a cigányság és afroamerikai zenészek társadalmi pozícióinak etnicizált/racializált strukturális homológiája), sajátos zenei gyakorlatokra utal. 
játszanak. A harmóniaköröktől el-elszakadó free jazz-szel ellentétben, itt a harmóniakörhöz való ragaszkodás teljesen megszünik, valós idejü, „spontán kompozícióban” jön létre a zenei alkotás.

Sajnos a több szinten egymásba kapcsolódó, különféle irányzatokat beolvasztó két gyüjtőkategória magyarországi kialakulásáról terjedelmi okok folytán csak a föbb referenciák szintjén esik szó. A következő hosszabb idézet szintetizáló jellege folytán a téma szimbolikus „látleletének” is tekinthető, mert - nem kellő differenciáltsággal ugyan -, de jól illusztrálja a magyar jazz erőtér struktúráját meghatározó alapoppozíciót. Az értelmezés szempontjából fontos adalék, hogy az interjúrészletben leírt szituáció egy jazz-zenész kolléga temetésén játszódik:

Annyira erős volt, hogy a két csoport ránézésre mennyire visel bizonyos jegyeket, mennyire definiálja magát már külsőleg, (...) azzal hogyan viselkedik és, hogy mennyire nem vegyül láthatóan. Ott lehetett azt érezni, hogy az alapproblematikája a magyar jazznak az, hogy mind a két csoport rettenetesen zár. Pont ugyanannyira ítélik el, nézik le, zárják be a kapukat egymás előtt. ${ }^{133}$ Nem gondolom az egyiket jobbnak, mint a másikat. Mindkettőt szeretem tisztelem és látom a hibáit, azt gondolom, hogy az én alapdefinícióban egyik sem összeegyeztethető, amennyiben az a nyitottság.

Az idézet magába foglalja a következökben részletesen kifejtett viselkedésben, habitusokban, esztétikákban megjelenő fontosabb oppozíciókat. A kutatás témájára vonatkoztatva az idézet tanulsága abban áll, hogy a fenti dichotómia részletes elemzése révén megragadhatók a szcénát alkotó főbb legitimációs elvek és konfliktusok rendszere, melyet a következő táblázat foglal össze sematikus jelleggel.

\footnotetext{
${ }^{133}$ A közölt interjúrészletekből a továbbiakban kurzívval szedem a kiemelten fontos részeket - H.Á.
} 
1.Táblázat: A budapesti jazz-színtér szerkezetét strukturáló oppozíciók

\begin{tabular}{|l|l|l|}
\hline & Mainstream Jazz & Free Jazz \\
\hline Oppozíciók & & \\
\hline 1. Magyar referenciák & „Romajazz-elit” & Szabados és köre \\
\hline 2. Nemzetközi referenciák & $\begin{array}{l}\text { Klasszikus zene és (kortárs) } \\
\text { mainstream jazz }\end{array}$ & $\begin{array}{l}\text { Mainstream kanon free } \\
\text { korszakai, kortárs avantgárd és } \\
\text { free jazz }\end{array}$ \\
\hline 3. Fellépőhelyek & Változatos, háttérzene is & Intimebb, föleg kisebb klubok \\
\hline 4. Szerkezeti elvek & $\begin{array}{l}\text { Bebop, jazz sztenderdek, } \\
\text { szving }\end{array}$ & Bebop csak eszköz \\
\hline 5. Technikai elvek & Domináns & Domináns, tempó kevésbé \\
\hline 6. Zenei habitus & $\begin{array}{l}\text { Professzionális jazz-zenész } \\
\text { „fanatikus” ethosza }\end{array}$ & $\begin{array}{l}\text { Autonóm müvész zenén } \\
\text { túlmutató ethosza }\end{array}$ \\
\hline 7. Jártasság stílusokban & Multistiláris (latin, free) & Individualista \\
\hline 8. Esztétikai szempontok & „Tökéletesség” & „Felfedezés” \\
\hline 9. Elöadói stílus/játékmód & „Artikulált”/Idiomatikus & „Artikulálatlan” \\
\hline 10. Belső kritika & Dogmatizmus, ortodoxia & Dogmatizmus, ortodoxia \\
\hline 11. Külsö kritika & „elitizmus”, „arisztokratikus” & Képzetlen, öncélú, provokatív \\
\hline 12. Autentikusság kritériuma & $\begin{array}{l}\text { Kommunikáció, összjáték, } \\
\text { fanatizmus }\end{array}$ & $\begin{array}{l}\text { Intellektuális/spirituális } \\
\text { kompetenciák }\end{array}$ \\
\hline 13. Individualitás kifejeződése & $\begin{array}{l}\text { Viszonylag zárt zenei } \\
\text { struktúrán belül (sztenderdek) }\end{array}$ & Spontán kompozíción belül \\
\hline
\end{tabular}

\section{4. Magyar és nemzetközi referenciák}

Rögtön az elemzés elején fontos kiemelni, hogy az 1. táblázatban szereplő ellentétpárok csupán a pozíciók terét, két szélső pólusát jelölik ki, a zenészek többsége valahol a táblázat oppozíciói által kijelölt térben helyezkedik el. A fejezetben tárgyalt fő alapoppozíció elemzése akkor is megállja a helyét, hogyha a free- és szabadzenészek közössége országosan nem tesz ki néhány tucat zenészt, ${ }^{134}$ mert az általuk képviselt esztétikai alapelvekhez az

${ }^{134}$ A magyar free jazz egyik meghatározó zenésze szerint kb. huszan számítanak a free szcéna alapemberének. Szabad zenét és free jazzt játszók ennél többen is vannak, de abban nagyjából egyetértés van, hogy aki 
erőtér különböző pozícióit betöltő zenészek valamilyen módon viszonyulnak. Elemzésem során főként arra fókuszálok, hogy a Magyarországon jazzt játszó zenész milyen esztétikai hierarchizálódással összefüggő kontextusokban kell alkosson, mely az erőtérben működő osztályozási sémákkal van összefüggésben.

A free-mainstream különbségtétel a magyar és nemzetközi referenciák közti tipizálható eltérésekben is megmutatkozik. ${ }^{135}$ A magyar jazzhagyományt illetően, a tradicionálisabb mainstream jazzt játszó kör egyértelmủen az államszocializmus időszakában meghatározó, első generációs roma származású mainstream jazz-zenész nemzedéket említi: Ablakos Lakatos Dezsőt, Pege Aladárt, Szakcsi Lakatos Bélát, Kőszegi Imrét. A nemzetközi előadók közül pedig az ismert mainstream kánont; Charlie Parkert, Dizzy Gillespie-t, Miles Davist stb. emelik ki, - a hangsúlyok persze hangszerenként valamelyest eltérnek és tipikusan a fentebb felsorolt jazzóriások zenekaraihoz köthetők. A magyar szabad zene prófétáját, Szabados Györgyöt ez a kör csak nagyon elszórtan említi, ha mégis igen, legtöbbször a kutató témafelvetése kapcsán és nem zsigeri referenciaként, mint a fenti zenészeket, kikre sokszor bálványként tekintenek, fetisizálnak és egyesek egyenesen sértésnek veszik, ha kritizálják a mainstream panteon tagjait.

A free (jazz) zenészek körében (magukat „szabadzenésznek” is vallók közül) viszont szinte kizárólag Szabados Györgyöt és körét tekintik magyar viszonyítási alapnak, ${ }^{136}$ nemzetközi jazz-klasszikusokból pedig meghatározó zenészek, pl. John Coltrane, Charles Mingus free jazz korszakait hangsúlyozzák, így a klasszikus mainstream kánon, a két irányzat közös halmazának free szegmenseit. A nemzetközi irányzatok közül eröteljes referenciaként vannak jelen a kortárs klasszikus zene (John Cage, Steve Reich) és az európai free jazz (Alexander Schlippenbach, Peter Brötzmann) képviselői is. Az utóbbi két német zenésszel rendszeresen játszanak együtt Magyarországon és Európában. Zenei identitásukban, tradíciófelfogásukban nem zenei források is hangsúlyosak: témafelvetéseim

„komolyan veszi” és jól múveli az néhány tucat, főleg Grencsó István free jazz szaxofonos holdudvarába tartozó free zenész és más olyan autonóm, jelentős nemzetközi karrierrel is rendelkező művészek mint Gadó Gábor, vagy Szelevényi Ákos.

${ }^{135}$ A fejezetben csak a fő jazz-referenciákra térek ki, a különböző klasszikus és populáris zenei referenciákat most nem tárgyalom, mindössze megjegyzem, hogy a két csoport Bach- és Bartók-interpretációi is eltérő mintázatokat mutatnak eddigi, főkép résztvevő megfigyelésből származó ismereteim fényében.

${ }^{136}$ A magyar free jazzt játszók egyetlen személyhez, Szabados Györgyhöz köthetők. Akik játszották a műfajt, vagy kísérleteztek vele (Dresch Mihály, Grencsó István, Geröly Tamás, Baló István, Benkő Róbert, Tickmayer István, Binder Károly, stb.) mind az ő „körébe” tartoztak. 
kapcsán több free zenész utalt zenetudományi és esztétikai munkákra az interjúk alatt. A zenei hivatkozások tehát nem válnak el teljesen egymástól, mégis, a zenei identitásokkal mélyen összefüggő nemzetközi és magyar jazz-zenei hagyományokból mást tekintenek legitimációs alapnak. ${ }^{137}$

A free kör tagjai továbbá kiemelik, hogy a Zeneakadémia szinte teljesen kiírja a kánonból az olyan, számukra alapvető „újítókat” (pl. Albert Aylert, vagy Sun Ra-t), illetve a fent is említett európai free jazz nagyjait. Körükben a párhuzamos akadémia visszatérő toposzként jelenik meg, mely egyértelmủen utal az államilag elismert karizmatikus felszentelő apparátus, a Zeneakadémia Jazz Tanszéke, és a formálisan (még) ${ }^{138}$ nem intézményesült „eretnek” státuszú szabad zene ellentétére. Egy jazztanszakot végzett free zenész hangsúlyozza, hogy számára a „legnagyobb iskola a Grencsó Kollektíva, hogyha meg kell nevezni, akkor nekem ez a Tanszak."139

\section{5. Doxa és dogma: A tradícióhoz való viszony jelentéstartalmai}

A különböző jazz-definíciókhoz tartozó pozíciók terének modellezése során fontos annak vizsgálata, hogy a két csoport hagyománykonstrukciója, vagy zenei identitással összefüggő hagyományértelmezései milyen legitimációs funkcióval bíró zenei referenciákra támaszkodnak. A nemzetközi és magyar referenciák eloszlásának leírása után, a hagyomány(ok)hoz füződő viszonyrendszer jelentéstartalmainak konfliktusközpontú bemutatása a következő lépés a mező rétegződését meghatározó alapelvek megragadása felé. A hagyományalkotás és hagyományalkalmazás a csoportokon belül és csoportok közt is

\footnotetext{
${ }^{137}$ Egyik fö, kortárs hivatkozási alap számukra Schlippenbach freejazz-zongorista 'Monk’s Casino' c. albuma (2005), mely Thelonious Monk (1917-1982) amerikai zongorista összes kompozíciójának feldolgozását tartalmazza. A „klasszikus” Monk-szerzemények free jazz interpretációja jelképezi a mainstream kánonhoz való, a fejezet során részletezett viszonyukat, melyet az utánzás és interpretáció („továbbvivés”, „saját nyelven való játék" stb.) ellentéte ragad meg hitelesen.

${ }^{138}$ Első alkalommal 2015-ben Szabados lakhelyén, Nagymaroson szervezett ADYTON Szabad Zene Mühely és Alkotó Együttlét (tábor) fontos intézményes fóruma a szabad zenei szcénának (Ráduly, 2015a).

139 A „párhuzamos tanszak” fogalma és ellenalternatíváját említi az interjúrészletben hivatkozott Szabados örökségét továbbvivő Grencsó István is egy interjúban (Maloschik, 2016): „Szabados György megkeresett és elhivott a szeptettjébe. Na, akkor kezdödött az én jazz iskolám... " Beszédes, hogy maga Szabados sem vett részt semmilyen intézményes zeneoktatásban (Ráduly és Bognár, 2016) és a kortárs szabadzenészek sokszor az akadémikus oktatás hiányosságainak tudják be a fiatalok egyre nagyobb érdeklődését a szabad zene irányába (Ráduly, 2015a).
} 
konfliktusos területnek számít, ezért az interjúrészletek interpretációja mellett tudatos módszertani elemként ellenpontozom a különböző irányzatokhoz köthető zenészek azonos kérdésekkel kapcsolatos megnyilvánulásait.

A hagyományalkotással kapcsolatos alapellentét a tradíció konzervatív és progresszív értelmezéseinek és alkalmazásmódjainak különböző dimenzióiban jelenik meg. Míg a mainstream közeg az amerikai klasszikusok által lefektetett mainstream zenei nyelv „szentháromságát”, a (1) kötött harmóniára történő sztenderdjátékot, (2) a szvinges tempót és (3) frazeálást, vagy előadásmódot tekinti követendő példaként, a szabadzenészek a hangsúlyt az újítás hagyományára, a tradíció ellen való lázadás tradíciójára helyezik, ahol nem egy-egy újító esztétikájának professzionális elsajátítását, de az innováció, az útkeresés sokszor kockázatos gesztusát tekintik alapvetésnek.

A free jazzben olyannyira alapvető, kötött harmóniaköröktől való eltávolodásnak lényeges esztétikai aspektusai is vannak, melyet a zenei referenciák interpretációja is jól jellemez. Egy free zenész rámutat arra, hogy a technikai különbségeken túl a fő distinkció mainstream és free jazz közt esztétikai jellegü, mert a free jazzben is vannak harmóniakörök. A lényeg szerinte a „tökéletesség és a tökéletlenség esztétikájának ellentéte, (...) a tökéletlenség esztétikája azt hangsúlyozza, hogy többet ér a kísérletezés, mert új dolgok születhetnek meg." A közös referenciák, pl. Charlie Parker interpretációja során a free zenészek a radikális újítást hangsúlyozzák, nem az újító által megteremtett nyelv esztétikai sajátosságait:

Parker az avantgárd volt akkor, ezt felejtik el a mainstream zenészek. A hagyomány nagyon fontos, de ugyanazt csinálni mint a Parker, [annak] végképp semmi értelme. Semmi bajom a beboppal, ma fel lehet használni a bebopot mint elemet.

A mainstream esztétikájából a bebop „mint elemnek” a felhasználása - és nem abszolutizálása! - jól láttatja a két „,ábor” közti lényegi különbséget. Mainstream oldalról viszont, Parker kapcsán az új zenei nyelv, a bebop, megteremtésének és emancipálásának technikai, előadásmódbeli elemeit és a folytonosságot emelik ki, a hangsúlyt markánsan a korábbi ortodoxiák felforgatására helyező fenti idézettel szemben: 
Tiszteljük meg a történetünket, a Charlie Parkert... A legnagyobb újító, mindenki belőle jött. Elkezdtek modern harmóniákat játszani, elkezdett a jazz a modern müvészet felé haladni, nem csak a tánc. (...) Játszunk el egy Anthropology-t, ${ }^{140}$ hallod hogy mi jó és mi nem.

A fenti két interjúrészlet jól reprezentálja a két alapállás közti különbséget. Míg a mainstream zenészek Parker személyében a „teremtetlen teremtőt” (Bourdieu, 2013: 211) értékelik, azt a művészt, aki lerakta a modern jazz „törvényeit” (sic), a free zenészek ezzel szemben Parkert az idejétmúlt dogmák lerombolójaként tisztelik. Röviden, a két interpretációban a doxa megteremtője áll szemben a dogma megsemmisitőjével. Ezek az interpretációk nem esetlegesek, hiszen a „tradícióhoz” való tipikus viszonyulási módokra utalnak. A zenészcsaládba született nagy presztízsű roma származású jazz-zenész fenti Parker-interpretációjában egyúttal hangsúlyos elemként van jelen a szórakoztató tánczene (,,nem csak a tánc”) és „,modern müvészet” oppozíciója. A cigányzenészek számára a jazz magaskulturális státusza zenei identitásuk fontos elemét alkotja. A mainstream jazzt ideologikusan képviselő, tipikusan roma jazz-zenészekhez társított csoport jellemzője, hogy „fanatikusan” képviselt zenei professzionalizmuson alapuló identitásuk védelmében a köreikbe történő belépést magas szinten kodifikálják. A jazz egyedüli, megkerülhetetlen és hiteles megnyilvánulásának tételezett mainstreamjazz-esztétika magas szintủ elsajátítása részükről szükséges feltétele az elismerésnek, így az együttjátéknak. Visszatérő elem annak hangsúlyozása, hogy „aki nem tud szvinget, meg bebopot játszani” azzal nem tudnak, és nem is akarnak együtt muzsikálni. ${ }^{141}$

A fenti tradícióértelmezéssel szemben foglal állást a legtöbb free zenész, ahogy a következő idézet is szemlélteti, ahol már Bartók a fö hivatkozási alap.

A jazz nekem egy valamit jelent és ez a progresszió. Egy olyan zenét jelent, ami most van. Ahogy Bartók mondta, meg van a minden művészetnek a joga ahhoz, hogy előző művészetben gyökerezzen, de ez nem azt jelenti, hogy kötelessége is és, hogy pusztán ezért jó müvészet lesz.

A mainstream konzervativizmusra jellemző esztétikai kontinuitás ideáljával szemben, a progressziót és innovációt hangsúlyozó free zenei identitásnak magától érthető része az

${ }^{140}$ A ’40-es évek második felében rögzített Parker kompozíció (1990), melynek a harmóniaszerkezete „rythm changes" kötelező alap mindenkinél, aki jazzt akar játszani.

${ }^{141}$ A jazz-zenész definíció konstrukcióját a mainstream csoport is problematikusnak érzékeli, erröl tanúskodik a következő idézet is, melynek számos variánsával találkoztam az interjúk során: „A legnagyobb probléma itt a fogalommal van. Itt most boldog-boldogtalan jazz-zenésznek hívja magát. A jazz, mások ezt lenézik, a bebop és a mainstream." 
epigonizmus és az utánzás erőteljes elvetése is. ${ }^{142} \mathrm{~A}$ free nézőpont markánsan jelen idejű, nem csak a kötött formáktól, de magukat a tradíció látens és intézményes elvárásaitól is szabadnak láttató, „tiszta esztétikát” képviselő ethosza az egyediséget, innovációt és hitelességet kéri számon a „tradicionalista” mainstream zenészeken: ,írók esetében, ha nincs saját nyelved senki vagy, a zenében viszont ellubickolsz". Jellemzően úgy látják, hogy a mainstream zenészek túlhangsúlyozzák a jazz technikai oldalát, mely által „elveszitik a spiritualitást a zenéből”, ami ellen „a free jazz kínál alternativát”, egyúttal a belépési adó számukra zenei szempontok dimenzióján kívül konstruálódik: a mainstream jazz elsajátítása által csak ,jazz-zenész leszel, de nem egy autonóm müvész”.

$\mathrm{Az}$ „autonóm művész” intellektualizáló ethoszának egyik fontos motívuma a mimetikus zenei magatartások tudatos tagadása, ugyanis a free zenészek szerint a mainstream muzsikusok sok esetben a minél pontosabb utánzásban találják meg az esztétikai ideált. Többször parodizálták pl. a mainstream zenészeket, olyan szituációkra utalva, mikor egymást azzal dicsérik egy szóló után például, hogy a játék olyan volt, mint valamely híres zenésznek a stílusa. A mainstream zenészek viszont egy-egy „klasszikus” játékmódjának elsajátítását nem tekintik „főben járó bűnnek”, ami azt illeti, hiányolják az olyan zenészeket, akik kijárták a mainstream iskolát, és egy adott zenész stílusában lennének képesek játszani, ugyanakkor ez nem végcél számukra, csupán a képzettség egy fokmérője. Egy, a mainstream esztétikának elkötelezett, nagy presztízsű roma zenészekkel készített csoportos interjú során egyikük gúnyosan jegyzi meg, hogy szeretne „Parker-epigonokat” hallani, és szerinte már a nagy elődök szakmailag helytálló utánzása sem lebecslendő, müvészi szempontból alantas dolog. Szerinte, „komoly harmóniákra történö improvizáció során” bontakozik ki a zenei individualitás, ezért, mivel a free zenészek nem rendelkeznek olyan rutinnal és professzionalizmussal a mainstream jazzben mint ők, nem is tekintik hitelesnek a szabadzenészek zenei megnyilvánulásait.

A következő, mainstream zenésztől származó idézet jól illusztrálja a zenei presztízs szempontjából fontos distinkciót a nagy újítók puszta utánzása és az általuk lefektetett zenei nyelvre épülö improvizáció között, mely utóbbiban teret nyer az alkotó individuum, aki a hitelességét, a kifejező nyelvi hasonlatnál maradva, a „mondatrészek” hangsúlyozásából és a szerkezeti variációk végtelen lehetőségeiből nyeri:

${ }^{142} \mathrm{Az}$ „epigonizmus” pejoratív szerepéről a formális zenei képzés szelekciós eljárásai során lásd pl. Nylander (2014) munkáját. 
Ha jazzt játszol eleve a fantáziádnak, kreativitásodnak, improvizációdnak nagyon komoly súlyt kell fektetnie arra, hogy ne próbálj meg Charlie Parkert játszani, (...) hanem próbáld magadat játszani.

A „tradicionalista” és free közeget egyaránt erős kritikával illető, egyik szélsőséghez sem sorolható zenészek is hasonló dogmatizmuskritikát fogalmaznak meg a mainstream közösséggel szemben, mint a free zenészek, - noha többségük a free zenészeket is tipikusan zárt, és dogmatizmusra hajlamos csoportként írják le. ${ }^{143}$ A táborok közti - egyébként nem jellemző - átjárások a szerint alakulnak, hogy az adott zenész mennyire van tisztában az adott free, vagy mainstream referenciarendszerrel (pl. sztenderdek ismeretével) és zenei képességekkel (pl. bebop). A megkérdezett zenészek tipikusan ugyanazt a $\sim 2-3$ zenészt említik, akik mindkét irányzatban autentikusan képesek alkotni. Mikor mainstream zenészeknél rákérdeztem, hogy kit fogadnak el, kikkel játszanak/játszanának együtt szívesen, akkor egyértelműen a sztenderdjáték bizonyult belépési adónak, valamint a free mainstream jazz közti különbségtétel egyik alapvető motívumának.

A zenei és ideológiai jelzők ellentéte utal arra, hogy az absztrakt jazzelméleti szabályok koránt sem ártatlan alapelvei a jazz-zenészek közösségének, de (ön)legitimációs funkciót töltenek be, ahogy erre a bebop keletkezését tárgyaló pályadíjas ${ }^{144}$ művében a téma kurrens kutatója, DeVeaux (1997) is rámutat. Így a fő referenciákhoz köthető esztétikák elsajátítása a jazzszcénában tőkeként funkcionál, és meghatározza, hogy a különböző társadalmi hátterü zenészek hogyan értékelik az illetőt. Egy fiatal, a mainstream jazzt épp elsajátító zenész pl. arról számol be, hogy egy jam session során nem feltétlenül szerencsés a mainstream panteon bizonyos előadóit - pl. Miles Davist - kritizálni, mert a tipikusan romákkal azonosított „szélsőségesen ideologikus” mainstream zenészek adott esetben ezt sértésnek is vehetik: „,azért nem vernének meg, de akár még ilyet is mondanának, hogy »nem csoda, hogy itt tartasz«, ha Davis-t kritizálod”. A Davis-kompozíciók ismerete alaptudásnak, belépési adónak tekinthető, jelen esetben a mainstream jazzt játszók körébe, egyúttal a szimbolikus kirekesztés instrumentumaként is szolgál. Egy Skype-interjú során,

143 „Van az a vonal, akik azt mondják, hogy amiben nem kézzel fogható módon van jelen a tradíció már nem értékelhetö. Én meg úgy látom, hogy ez egy borzalmas önátverés. A müfaj tradicionalista vonala, maga alatt vágja a fát. Pontosan azért, mert nem zenei, hanem valamilyen elvi, ideológiai alapokra helyezi."

„Vannak, akik a jazz hagyományaira építik a zenéjüket, ez egy nézőpont. A másik pedig, hogy a jazz az, ami mindent magába olvaszt."

${ }^{144}$ DeVeaux egyéb nagy presztízsű szakmai díjak mellett a '98-as American Book Award nyertese is. 
mikor a külföldi szcénáról, jam sessionökről szerzett tapasztalatiról kérdeztem a kint élő zenészt, a kinti gyenge színvonalat egyenesen úgy interpretálta nekem, hogy a mainstream sztenderdre gyengén játszó zenészt „,Az [XY jazz-zenész] leszúrná [sic!]”. Azzal, hogy az anonimitás okán itt nem megnevezett zenészt hozta fel (szélsőséges) példának, tulajdonképpen azt hangsúlyozta, hogy a szóban forgó zenész számára mennyire alapvető fontosággal bír a fent sematikusan ismertetett mainstream esztétika, így a sztenderdek ismerete. Továbbá, sokat elárul a magyar jazz presztízshierarchiáját meghatározó mainstream/free jazz distinkció relevanciájáról, hogy a magyar származású, külföldön alkotó jazz-zenész is a magyar mainstream elit nézőpontjából minősíti kinti jazzszcénát.

A szociológiai, vagy tudományos mező müködéséhez hasonlóan, ahol a szakmai autoritásokhoz köthető nagy elméletek és iskolák egymás kölcsönös delegitimációját is ellátják (Bourdieu, 1991c) úgy - a strukturális homológia logikáját követve - a mainstream és free irányzatok ideológiai konstrukciói is hasonló funkcióval bírnak. A magát „szabadzenészként” pozicionáló szerző, Pozsár Máté (2016a) Jazzelmélet tankönyve ${ }^{145}$ fontos állomása lehet a progresszív free esztétika emancipációjának is. Az „összegzőkorrigáló” jazzelmélet tankönyv formában történő objektiválódásával olyan újabb pozíció íródik az erőteret szervező relációk univerzumába, mely intézményesíti a kanonizálódottuniformizált tradicionális esztétika és a mainstream kánonból is sokat merítő progresszív jazzelmélet-oktatás oppozícióját.

A mainstream körre utaló „újítás a tradícióban” megfogalmazás azért lehet kifejező, mert az önmagukat is határozottan ide soroló zenészek - tehát koránt sem a kutató önkényes klasszifikációja alapján - sokszor szinte teljesen azonos kategóriákkal konstruálják meg zenei identitásukat, mint a free zenészek, csak egy zártabb esztétikai paradigmán belül. A szcénában használatos fogalmak univerzuma; „önmagad játszása”, „kreativitás” vagy „improvizáció” más-más jelentéssel bírnak az erőtér különböző pozíciói számára, tehát $a$ zenei habitusok konstrukciója során nem a kategóriák, hanem a pozíciókhoz köthetö alkalmazásmódjaik, interpretációik különböznek. Noha a budapesti jazz szcénát nem tekintem szubkultúrának (Havas és Ser, 2017) a megkérdezett jazz-zenészek, beszéljenek bármilyen pozícióból is, a jazzt a kreativitás, önmegvalósítás és szabadság terrénumának

\footnotetext{
${ }^{145}$ A könyv (Pozsár, 2016a) az amerikai, európai és magyar zeneelméletek integratív megközelítése mellett a „sok szempontból használhatatlan” (Pozsár, 2016b) mainstream magyar jazzelmélet-oktatás kritikáját adja pl. új fogalmak bevezetése révén is (pl. heptatónia, quartia).
} 
látják. ${ }^{146} \mathrm{~A}$ fentieket összegezve, a mainstream és free zenészek nézőpontjából származó interjúrészletek és kritikák lényege megragadható a progresszív-tradicionalista, múltközpontú-jelenidejü, ideologikus-esztétikai és újító-ortodox ellentétpárok révén. ${ }^{147}$

\section{6. A szimultán esztétikai hierarchia strukturális alapja}

A kutatás jelen szakaszában is körvonalazódnak alapvető különbségek a mainstream és free csoportok társadalmi beágyazódással kapcsolatban, melyet a szimultán esztétikai hierarchia strukturális alapjának tekintek, és a korlátozott információmennyiség okán itt csak érzékeltetni tudok. A free és mainstream jazz társadalmi beágyazódása, a most bemutatott bináris oppozícióknál sokkal finomabb szövetű és differenciáltabb, viszont a dolgozat témáját adó alapproblematika társadalmi vázát meggyőződésem szerint jól láttatja.

A korábbi fejezetekből kiderült, hogy a két irányzat képviselői egyrészt eltérő referenciákat jelölnek meg (akár egy zenész életútjából mást tartanak fontosnak), másrészt a közös jazzhagyományt is különbözően interpretálják, melyet fentebb a Parkerinterpretációk kontrasztja is illusztrált. A mainstream közeg jellemzően az amerikai mainstream kánont és roma jazz elitet emeli ki, míg a szabadzenészek köre egyértelmüen amerikai és európai free jazz és kortárs avantgárd mellett kihagyhatatlan referenciaként a magyar szabad zene alapító prófétáját, Szabados Györgyöt. Mivel a két irányzat magyarországi genezise kapcsán nehéz nem észrevenni néhány meghatározó, szociológiai szempontból releváns különbséget, a következőkben elsősorban a magyar alapreferenciák eltérő társadalmi beágyazottságára világítok rá néhány illusztratív erejü interjúrészlet segítségével.

146 Erre a megfigyelésre jut Szabó is (2014) mikor Hodkinson (2005) goth szubkultúrával kapcsolatos megfigyelései nyomán létrejött koncepciókat, pl. a „szubkultúra ideáljának” érvényességét taglalja a kortárs magyar jazz szcénában.

147 Az intézményes zeneoktatással asszociált „technokrata” kontra „autonóm” szabadzenész toposzának szembenállása már a '80-as években jelen volt Magyarországon: „,[A jazztanszakon a nyolcvanas évek elején] semmi mást nem ismertek el, csak a bebopot és a swinges lüktetést. A többi utálatos dolog volt a számukra. Egyszer elvittem a tanszakra egy kompozíciómat: »Ez óriási, Sanyika, gyönyörü! - mondták. - De nem ér semmit, mert nem jazz!!«. Zenei szakmunkásképzés folyt, ahol az improvizációkat, mint klasszikus motívumokat másolták. Példaképem Szabados. Minden általa eljátszott hang tartalmazza azt az igazságot, amit egy magyar zenész Bartók óta kimondott, illetve leüthetett a billentyün. A jazz magyarságáért más nem sokat tett. [...] Amatör vagyok, nem profi, nem játszom hat zenekarban, nem ebböl próbálok megélni, tehát szabad vagyok! (Libisch, idézi Havadi, 2011: 153).” 
Az orvos végzettségü, keresztény középosztályból származó Szabados a free jazzt játszók körében egyfajta iskolalapító totális értelmiségi váteszként reprezentálódik: a korszakban ő a par excellence párhuzamos tanszak, akinek esztétikai-ontológia elvei kínálják követői számára az alternatívát a free nézőpontból ortodox mainstream jazz-szel szemben, de a zenén túl is, egyfajta autentikus müvészi léthez. A ,félig-meddig muzsikuscsaládból való" Szabados (Szigeti, 2015: 7) 148 $^{148}$ zei munkássága mellett költeményeket szerez, esztétikai írásokat, elemzéseket is közöl, valamint saját kompozícióiban is explicit módon jelen vannak egyetemes társművészeti utalások. ${ }^{149}$ Lakhelyén, Nagymaroson, a visegrádi vár és a Dunakanyar közvetlen szomszédságában, a körülötte csoportosuló nem csak zenész értelmiségi körrel folytatott beszélgetései során adta elő nagyívű gondolatait a világrendszerről, mellette lakást tartott fent a II. kerületben, ami térszimbolikáját tekintve is ellentétes társadalmi miliőre vall az első generációs, számára kortárs roma származású jazz-zenészek belpesti beágyazódásától. ${ }^{150}$

Itt külön nem részletezett kulturális, politikai és piaci trendekkel összefüggő okoknál fogva, a két világháború közt teret hódító új nyugati irányzat, a jazz ellen a magyar zenekultúra nevében még kollektíve fellépő (Zipernovszky, 2014), szórakoztató cigányzenét játszó urbánus muzsikusgeneráció leszármazottjainak egy meghatározó csoportja ${ }^{151}$ a '60-as évektől kezdve már amerikai mainstream jazzt kezdett el játszani. A muzsikuscsaládból származó mainstream jazzt játszó roma zenészek egy jelentős részére jellemző, hogy

148 „Anyám Zeneakadémiát végzett énekesnő volt, majd később énektanár lett. (...) Már a háború előtt a Kodály által kezdeményezett zeneoktatási módszer szerint tanitott, úgyhogy mi otthon zeneileg is anyanyelvi környezetben éltünk. Miután anyám továbbra is énekelt - mint kórustag a Budapesti Kórusban, majd az akkori Székesfóvárosi Énekkarban - igy gyerekfejjel sok világhírü karmester környezetében forgolódtam. (...) Otthon a családban is szalon-zenei élet folyt, ami azt jelentette, hogy szinte mindig zenével voltunk körülvéve" (Szigeti, 2015: 7).

${ }^{149}$ Pl. A zarándokok tánca a cédrusfánál Libanonban című Csontváry-darab, de ha kortárs free zenészek albumait közelebbről szemügyre vesszük, találhatunk bennük zenészektől származó verseket, írásokat, töredékeket (pl. Gadó Gábor 2008-as Byzantium, vagy Grencsó István 2014-ben megjelent Síkvidék c. albumán). A free jazz paradigmában a társművészetek felé való tudatos nyitás is szimbolizálja az autonóm mủvész zenén túlívelő ethoszának és a professzionális mainstream zenész ideáljának ellentét.

${ }^{150}$ A fejezethez Hadas Miklóssal folytatott beszélgetéseimet is felhasználtam, aki Szabados körének tagjaként autentikus információkkal gazdagította a kutatásom.

${ }^{151} \mathrm{Az}$ első generációs jazz-zenészek közül a teljesség igénye nélkül Szakcsi Lakatos Béla, Pecek Géza, Ablakos Lakatos Dezső, de a középgenerációba tartozók közül is sokan (esetenként évszádnyi távlatban is) zenészcsaládok leszármazottja pl.; Oláh Kálmán Balázs Elemér, Egri János, Snétberger Ferenc, akiknek gyermekei már szintén elismert jazz-zenészek (Oláh Krisztián, Ifj. Egri János, Ifj. Oláh Kálmán stb.). 
szövevényes rokoni viszonyain túl, azonos környéken is szocializálódott, sokszor akár több zenészcsalád lakott egy bérházban. A VIII. kerületi Mátyás teret interjúkban, informális beszélgetésekben is kultikus helyként emlegetik, ahol ezt az első nemzedéket követő - és a kortárs jazzélet elismert tagjainak jelentékeny részét adó - generáció tagjai is rendszeresen találkoztak egymással, ${ }^{152}$ ahogy arra Oláh Kálmán zongorista utal egy interjúban, melyben kifejti, hogy „A jazz nyilván a Mátyás téren jött, futballozás közben” (Maloschik, 2002), ahol sok jazz-zenésszel volt alkalma találkozni, így a müfajt már fiatalon megismerhette. Ferenczi Gábor (1994) a Trio Midnight zenekarról (Oláh Kálmán, Balázs Elemér, Egri János) készített dokumentumfilmjének néhány interjúrészlete a társadalmi beágyazódás témája szempontjából is tanulságos, pl. mikor a nemzetközi sikereket is aratott roma származású dobos, Balázs Elemér, magát „népizenésznek” (sic!) aposztrofáló édesapja beszél fia pályafutásának kezdetérool:

A Béláékkal egy udvarban laktunk, a Szakcsiékkal. Az Elemér 3 éves korában amit hallott a rádióban tánczenéket már dobolt rá, meg énekelt. (...) A feleségem testvérnek a lakodalma volt és együtt játszottunk a Bélával. Említettem neki a fiamat, mondom hallgasd már meg Béla, hogy mit szólsz hozzá, mert (...) nagyon tehetséges, és akkor szólt az Elemérnek, az meg egy asztalon elkezdett dobolni, de ugyanúgy kihagyta neki a szólókat (...), akkor, hát, elájult rajta, mert rendesen periódusra dobolt (...) és akkor még nem ismerte a dobot.

$\mathrm{Az}$ interjúrészlet szintetizálja a kapcsolathálók szerepének fontosságát, a közeg városszociológiai jellemzőit és a generációk közti mobilitást, mely a szórakoztató zenéről a mainstream jazzre történő generációs váltásban nyilvánul meg, ezért ebben az értelemben a fenti interjúrészlet koránt sem egy partikuláris pályaívre, de egy tendenciózus jelenségre utal, és szorosan összefügg a romák által - de koránt sem csak általuk - professzionális szinten üzött mainstream jazz ideologikus, zenei identitással összefüggő konstrukciójának jelentéstartalmaival. Egy alapvetően szubaltern pozícióban lévő kisebbségi társadalmi csoport, a cigányság jellemzően urbánus elitjét képező muzsikuscigány réteg egy '50-es években kezdődő generációs váltás során már nem a szülők által művelt szórakoztató, „kávéházi” zenét, hanem a magas kultúra áthallásaival bíró amerikai feketék társadalmi emancipációjával is szorosan összefüggő mainstream jazzt játssza. ${ }^{153}$ Ez érthetővé teszi,

${ }^{152}$ Lásd pl. Jávorszky magyar jazztörténetet feldolgozó könyvének Progresszió és mainstream címü fejezetét (1999: 128-170).

153 A kép persze itt is jócskán árnyalható, pl. a Balázs Elemér Quartet közremüködésével létrejövő Contemporary Gregorian (2005) albuma, vagy Oláh Kálmán klasszikus zenét és jazzt ötvöző (crossover) 
hogy számukra miért kiemelten fontos a tradícióhoz való ragaszkodás, szemben az inkább értelmiségi hátterű free jazzt játszó zenészekkel. ${ }^{154}$ Röviden, a generációs váltás lényegét a kulturális hierarchiákban fölfelé történő mobilitás adja.

A fenti, koránt sem kellő differenciáltsággal ábrázolt strukturális pozíció nyomán az a későbbiekben árnyalandó munkahipotézis fogalmazható meg, hogy a társadalmilag kevésbé integrálódott társadalmi csoportok, esetünkben a mainstream jazzt ideologikusan képviselö roma származású zenészek számára az esztétikai ortodoxia és a tradícióhoz való ragaszkodás a jazz-zenei mező domináns pozícióinak betöltése mellett a társadalmi mezőben is legitimációt biztosít. Az alapvetően középosztályos, polgári-értelmiségi hátterü free közegben a tradíció követése kevésbé fontos (ön)legitimációs elem, ezért a művészi kifejezőeszközeik is eltérnek a mainstream zenészekétől, pl. a társművészetek ismertének hangsúlyozása és a kortárs avantgárd zenével kapcsolatos ars poétikusan vállalt nyitottság által. A fentiek értelmében, a két irányzathoz tartozó zenészek eltérő osztályhátterük révén internalizált tartós diszpozíciók vagy habituskonstrukciók folytán töltenek be eltérő pozíciókat a vizsgált erőtérben, melyet a különböző pozíciókat betöltő zenészek értékelő és osztályozó sémái strukturálnak.

\section{7. A free pólus differenciálódása és dogmatizmusa}

A fejezet Ráduly és Bognár (2016) Szabadosról folytatott beszélgetés címének („Nem a tagadást kell tagadni, hanem állitani kell") további, alapvetően interjúelemzésre építő kontextualizálásaként is tekinthető. A magyar szabadzenei tradíció kapcsán kihagyhatatlan a kortárs magyar jazz-zenei erőtér rétegződését is alapvetően meghatározó, Szabados által megteremtett pozíció néhány alapelvére reflektálni. A '60-as évektől Szabados munkásságában testet öltő normarendszer és esztétika legalább négy szintet foglal magába. Megjelenik a (1) hazai jazzéletben már pályája során konfliktusos amerikai mainstream és

nemzetközi sikeretek is arató kompozíciói tanúskodnak arról, hogy a tipikusan roma mainstream zenészeknek titulált kör is nyitott más zenei irányzatok, noha kevésbé a kortárs avantgárd felé.

${ }^{154}$ A nem reprezentatív kérdőíves kutatásunkban a válaszadó hallgatók és diákok fele említette a free és mainstream jazz konfliktusát, továbbá szintén a felük számolt be egy mainstream jazzt játszó roma elitrétegről, melyet egyfajta „sztárkultusz övez” (Havas és Ser, 2017). A hallgatók percepciójában tehát egyértelműn jelen van a fejezetben is tárgyalt dichotómia. 
free jazz oppozíciója, ${ }^{155}$ (2) a bartóki hagyományból örökölt aszimmetrikus ritmusok (Turi, 1991) és népzenei elemekből táplálkozó „parlando-rubato” előadásmód sajátosan magyar, szabadosi szintézise és az amerikai free jazz ellentéte, (3) a technokrata jazz-zenész és autonóm müvész szembenállása, (4) valamint a zene szféráján ugyancsak túllépő, egyfajta civilizációs-filozófiai diskurzus megteremtése, mely már a szabadság, nemzet, teremtés, rítus, egyetemesség és szakralitás fogalmak transzcendentális dimenziójába tartozik, és amelynek kifejtéséhez a zene volt számára a legalkalmasabb médium, - és nem öncél.

Ő nem jazz-zenészként viszonyult a zenéhez, hanem a gondolkodó, a zenét is a gondolkodásába építő emberként kereste a kapcsolatot a szakralitáshoz, a teljességhez, és a jazzben megtalálta azt a zenei formát, amely ezt a világlátást kifejezhette (Ráduly és Bognár, 2016: 14).

A továbbiakban az is bemutatásra kerül, hogy az újabb generációs freejazz-zenészek, ha tetszik, „Szabados unokái” ${ }^{156}$ milyen konfliktusok során alkotják meg az újítás tradíciójának folyamatos szintézisre épülő kísérletező hagyományát, és a mainstream ellen való lázadás mennyire tekinthető az európai ,új ortodoxia” magyar vonatkozásának. ${ }^{157}$ A kör belső konfliktusainak elemzése egyúttal explicitté teszi, hogy a vizsgált mező rétegződését nem pusztán homogén csoportok státuszharcainak dimenziójában értelmezem, de a kutatásom differenciált képet törekszik nyújtani az erőtér rétegződését meghatározó szimultán hierarchizálódás dinamizmusáról és fő tétjeiről.

Ami a külső, nem free pozícióból származó kritikákat illeti, technikai és esztétikai szempontokon túl, a free zenészek tradíciófelfogásával összefüggő jellemző kritika a tagadás esztétikájának önmagáért valóságával, vélt ürességével kapcsolatos, akár pont a Szabadostradíció továbbvitele kapcsán. Ugyanúgy, ahogy a free zenészek „kimerevedettnek”, „megcsontosodottnak” tekintik a mainstream esztétikát, úgy másik oldalról, a

155 Szabados annak ellenére érezte otthon magát a free jazzben és alkotott nemzetközi színvonalú kompozíciókat, pl. '64-ben $B$ - $A$-C-H élmények címmel, hogy ismerte volna a mozgalom amerikai képviselőit, pl. Ornette Coleman, vagy más kortás free jazz előadók munkásságát (Ráduly és Bognár, 2016).

${ }^{156}$ A kifejezést Zipernovszky Kornél szóbeli közlése nyomán vettem át, amit ezúton is köszönök neki.

${ }^{157}$ Rechniewski (2008: 22) az európai avantgárd free jazz mainstream ellen való lázadásának három szakaszát emeli ki a '60-as, '70-es évektől: először az amerikai jazzt mint alapmodellt kérdőjelezték meg, majd a ritmus és dallam, végül a maga jazz ellen lázadtak. Az amerikai mainstream jazz-paradigma felülírása sok prominens zenész szerint egy újfajta ortodoxia létrejöttét eredményezte Európában, mely a kortárs magyar free jazzben a Szabadoshoz való viszony értelmezései kapcsán merül fel. 
szabadzenészek körében hangsúlyos lázadást, progressziót és kísérletezést tekintik öncélúnak, sokszor egyenesen sznobizmusnak.

A szocializmusban tiltott volt, megtürt, kijött a rendőrség (...), régen ez volt a jazz. Most meg (...) az a lételem, hogy valahova fricskát nyomni, vagy valakiröl negatívumot mondani... Azt érzem, hogy sokszor abból akar építkezni, hogy (...) én milyen nem vagyok.

Szeretnének ő is valaminek kurvára megfelelni, közben azt gondolják, hogy mi most nagyon nem felelünk senkinek, és közben pont annak felelnek meg, hogy nem szabad megfelelniük senkinek.

A fenti kritikában felvillan a „tradíció ellen való lázadás tradíciójának” fonák oldala: a tagadás tagadása kontra állítás oppozíciója. Kifejezetten sokatmondó, hogy a fenti két idézet free jazzt és szabadzenét is játszó zenészektől származik, e köztes pozíciók nézőpontjából tehát a freejazz-tábor is dogmatikus. Mainstream nézőpontból pedig a progresszió, lázadás, útkeresés zenei gesztusait csak akkor tekintik elfogadhatónak, ha a sokszor artikulálatlan nem a bebop és mainstream jazz nyelvezetére épülő - megnyilvánulásokon kívül, artikulált zenei tartalmat, harmóniákat - vagy, ahogy egy interjúalanyom fogalmaz: „dallamszigeteket” - prezentálnak. ${ }^{158}$ Továbbá, ez a nézőpont egyértelműen utal a free szcéna dogmatizmusára, a mindenáron való, szubsztanciát nélkülöző, „öncélú tagadásra” és az anti-mainstream alapállást önmagában értéknek tekintő zenei attitüdre: „hibázni jobb, mint patterneket [sztenderdeket] játszani."

A dogmatikusan képviselt anti-mainstream esztétika a free szcénán belül is megosztó területnek számít. A csoportok önkritikus megnyilvánulásairól viszont nagyon kevés szó esik, az egymásról alkotott képek ezért jobbára leegyszerüsítők és statikusak, így az erőtérről kialakuló doxa erőteljesen hozzájárul a csoportok önszegregációjához: nem a közönségtől, ahogy anno Becker írta (1951), hanem a színtéren belül, - egymástól. A magyar szcéna egyértelmü sajátossága, hogy a konfliktusok mainstream és free zenészek közt sokkal alapvetőbbek - ugyanakkor látensebbek, szubtilisabbak, mert valós interakciókban ritkán

\footnotetext{
${ }^{158}$ A mainstreamtől való elhatárolódás a több évtizedes hagyománnyal rendelkező provokatív előadásmódban is testet ölt, pl. a közönségnek háttal játszás, szándékos alul- vagy (túl)intonálás, hangszerek megszólaltatásának felcserélése (gitáron vonózás), dresszkód elvetése a free jazz tipikus artifaktumainak számítanak. A közönségnek háttal történő játék jó metaforája az erőtér autonóm pólusának, ahol a müvészek ritualizált módon is elvetik a közönségnek - piaci igényeknek - való megfelelést, és egymásnak játszanak, képviselve így a piaci érdekek által nem bemocskolt „tiszta esztátikát”. A háttal játék a magyar free szcénára azonban kevésbé jellemző.
} 
öltenek testet -, mint a zeneileg dilettáns „kockafejü” közönség (Becker, 1951) és a képzett jazz-zenész közti elitizmusból (is) fakadó ellentétek. A dogmatikusan képviselt free esztétika belső kritikája jól láttatja a Szabados-tradícióval kapcsolatos mindennapi konfliktusokat is:

Nem mondhatom a mainstreamre, hogy nem tetszik pusztán sznobizmusból, mert freejazzzenész vagyok (...). Nincs szar zene, szarul lehet játszani, pont!

Szabados anyagot, amit játszunk, kurvára unom, (...) mert a Szabados nem arra tanította a tanítványait, hogy majd játszhatod a darabjaimat (...). Neki nem a zenéje a kulcsmozzanata, hanem arra tanította a körét, hogy gondolkozzon, és ne kapaszkodjon.

A szabadzenészek szektáriánusnak érzékelt közössége sem alkot homogén tömböt, és egyesek a csoport dogmatizmusára is problémaként tekintenek. A szcéna fragmentáltságával, „klikkesedésével” van összefüggésben, hogy a két nagy csoport által elsajátított nézőpont kölcsönösen statikus, differenciálatlan csoportokként láttatja egymást. Az erőtérről alkotott kollektív illúzió (Maanen, 2009: 62) komplexitásáról árulkodnak a free zenészek azon önkritikus megnyilvánulásai, melyek kifejezetten explicitté teszik és problematikusnak láttatják azt a szimultán esztétikai hierarchizálódásnak nevezett jelenséget. Ahogy a következő idézet is illusztrálja, a free pozícióból megfogalmazott kritika a mainstream jazz-szel kapcsolatban alkalmazható saját közösségükre is; a free zenészek is zárkózottak és olykor görcsösen ragaszkodnak esztétikai alapelvekhez, csak egy párhuzamos kánon prófétáinak esztétikai rendszerét - pl. Szabadosét - emelik az igaz zenei megnyilvánulás piedesztáljára, és nem a mainstreamjazz-esztétika szentháromságát, vagyis a free csoport is dogmatikus:

Nagyon komoly szektásodásnak a részei vagyunk, amin változtatni kell. Ezt abszolút jól látod, és fel is ismertük. (...) Tagadva nem lehet játszani. Olyan nincs hogy jön egy helyzet, és beugrik egy jazzes motívum, akkor nem játszod be. Szembesültem sokadjára ezzel, hogy pontosan ugyanolyan dogmák vannak nálunk, mint a mainstream zenészeknél.

A magyar free zenészek jól körülhatárolható, „szektásodott” kollektívájához nem közvetlenül köthető muzsikusok szerint a freejazz-szcéna azért nem hiteles, mert - ahogy a mainstreamben is -, egy szük csoport monopolizálja a legitim free zenész definícióját (kiemelés a szerzőtől: H.Á.). Ezt jól láttatja, hogy az artikulált és artikulálatlan zenei megnyilvánulások keveredése a freejazz-esztétikát opponálok szerint individuumhoz és nem egy csoport által meghatározott esztétikai normarendszerhez kötött: állítani ugyanis a két 
esztétika egyéni szintézisével is lehetséges, ${ }^{159}$ ahol a zenészen mint egy prizmán szürődik át artikulált és artikulálatlan elemek egyvelege. A free szcéna belülről is felismert dogmatizmusa ezt a szintézist tagadja az egyik szélsőséghez sem sorolható zenészek - tehát a zenészek többségének - meglátása szerint.

(...) ha nem basszuk folyamatosan, akkor mi nem vagyunk free zenészek. Mindenki a saját szintjén free, én szeretem keverni az artikulálatlan és artikulált dolgokat, (...) nézd meg a Wayne Shorter Quartettet, az olyan free, becsinálok, érted.

\section{8. Legitimitásharcok: A szimultán esztétikák technikai dimenziója}

A leginkább hangoztatott - mainstream körökben „mainstream-nek” számító - kritika a free zenészek hangszeres tudásával kapcsolatos. Önmaguk megkülönböztetésének egyik legfontosabb szempontja az amerikai jazztradíció tiszteletén és ismeretén túl a technikai tudás markáns hangsúlyozása, melyet a mainstream esztétika, a „nyelv” elsajátítását jelenti. A free zenészek hangszeres tudásával kapcsolatban két fó érvrendszer bontakozik ki visszatérő jelleggel. Az első alapvetően a zenei kvalitásokra vonatkozik, arra, hogy a free jazzt játszók megengedik maguknak a luxust, hogy nem sajátítják el hangszeres tudást, így a kötött harmóniáktól való elszakadás, a „szakmaiság hiánya”, teszi lehetővé számukra a ködös esztétikai elvek mögé bújó „kamuzást”, „kóklerkedést” és „,sznobizmust”.

Magyarországon azt veszem észre, hogy ez a kör egy picit sajátos kis útvonalon indult el, amivel majdnem, hogy lenézik azt, aki jól játszik bebopot!

A másik pedig arra a koncepcióra, hogy szabad zenét csak úgy lehet hitelesen játszani, ha a jazzista már kijárta a mainstream iskolát, így a mainstream zenészek a harmóniáktól való elszakadás kizárólagos előfeltételének (!) egy adott zenei narratívát tekintenek: „ $\mathrm{Ha}$ megtanulod a jazzt igazán, megtanulod nyelvet, akkor utána bármit tudsz játszani”.

A hangszeres tudáshoz kapcsolódó kritika a mainstream esztétikát leginkább szélsőségesen képviselők körében rivalizáló attitüddel párosul. Mivel többségük szerint csak azután lehet free jazzt játszani, ha már megtanultak mainstream jazzt játszani, a free zenész csak akkor válik hitelessé számukra, ha képes kötött harmóniakörre - sztenderdekre -

${ }^{159}$ Erre bőven akad példa a magyar szcénában: a Dés András Trió (Fenyvesi Márton, ifj. Tóth István, Dés András) pl. tudatosan keveri a szabad és előre megkomponált elemeket. 
improvizálni, melyre szerintük a free tábor tagjai képtelenek. Számos beszélgetés során elhangzott, hogy egy jam session szituációban derülne csak ki, hogy ki tud „,igazán zenélni” (sic), és, hogy a közös sztenderdjátékra a free zenészek többsége nem képes magas színvonalon: „Ök abba, hogy bebopot játszanak nem tudnak kibontakozni, mert nincs meg sajnos az a szint.” A „nincs meg a szint” minősítés a megkérdezett roma származású zenész mainstreamjazz-esztétika alapján történő önértékelését jelöli a szerintük gyöngébb technikai képességekkel rendelkező freejazz-zenészekhez képest. A mainstream nézőpont klasszifikációs sémái alapján a freejazz-zenei praxis „közepes legitimitásúnak” értelmezhetö.

Freejazz-zenészekkel készített interjúim során a mainstream jazz elsajátítása is fontos szempontnak bizonyult a zenei narratívák során, ${ }^{160}$ azonban ezt a mainstream zenészek által dogmatikusan képviselt esztétikai paradigmát szerintük meg kell haladni. Egy mainstream repertoárt játszó zenekar koncertje után az egyik free zenész zenekartag külön kiemelte, hogy a koncert is bizonyíték arra, hogy ők megtanulták a kötelező alapokat, hiszen én is (mint a kortárs jazzt kutató szociológus) hallhattam, hogy Charlie Parker számokra improvizáltak. Máskor önkritikus módon épp arra reflektált egy free zenész, hogy ők nem játszanak olyan jól mainstream jazzt, mert nem is szükséges előfeltétele a művészetüknek.

Nekünk sokkal rosszabb fülünk van ,mint egy cigány zenésznek, viszont sokkal kreatívabbak vagyunk, és ezért foglalkozunk ezzel, nyilván abba az irányba megyünk, ahol kisebb az ellenállás. Nem tudunk tempót játszani, viszont tudunk úgy játszani, hogy egyben legyen (...). Elvégeztük az iskolát, meghalljuk a hangközöket meg tudunk köröket játszani valahogy, de nem akarunk.

Teljes egyetértés tehát a kívülről homogén közegnek észlelt free közegben sem tapasztalható: mint láttuk párhuzamosan van jelen egyrészt saját presztízsük alátámasztása mint ,jazz-zenészek, akik kijárták az iskolát és meghallják a hangközöket”, másrészt az az elképzelés is, hogy nem kell olyan magas szinten megtanulni a mainstream jazzt, ahhoz, hogy értékes free jazzt vagy szabad zenét játszanak. A fent vázolt főképp hangszeres tudással kapcsolatos ellentét is azzal áll összefüggésben, hogy a két csoport eltérő esztétikai ideálok mentén alakítja ki zenei identitását és zenei habitusát, így mást tekintenek a legitim

\footnotetext{
${ }^{160}$ Emlékeztetőül: a freejazz-zenészek többsége is jazztanszakot végzett, „képzett” zenész.
} 
önmegvalósítás és művészi alkotás kritériumának. És ahogy láttuk, a két alapállást kevésbé az elfogadás, mint a legitimációs harcok és kisajátítási játszmák jellemzik.

\section{9. Spontán kompozíció}

Az esztétikai különbségtételek rendszerében idiomatikus és nem-idiomatikus, artikulált és artikulálatlan esztétikai elvek oppozíciója fontos szerepet játszik, melyet vázlatosan a várakozási horizont ${ }^{161}$ és spontán kompozíció fogalmaival kísérlek megragadni, egyúttal a két fogalom ellentét a szimultán esztétikai hierarchizálódás egyik meghatározó, szimbolikus distinkciókra vonatkozó aspektusának tekintem. Az idiomatikus/nem-idiomatikus megkülönböztetés arra utal, hogy van-e valamilyen fix struktúrája a zenének (pl. sztenderdjáték esetén a hangnem, és a kötött harmóniák, illetve a kompozíciók strukturális egységei, a „téma” stb.), vagy nincs ilyen fenti szempontok mentén megragadható strukturális alap. A nem-idiomatikus zene stílusokhoz nem kötődő (legalábbis tudatosan nem) valós idejű, („Echzeit”) szabad improvizációt jelent. A free jazzben pedig idiomatikus és nem-idiomatikus elemek egyaránt keverednek, mely megkülönböztető kategóriát maguktól a (free) zenészektől vettem át. Az ellentét értelmezésének egyik lehetséges útja, ha az individualitás szemszögéből (is) bemutatásra kerülnek e különbségek. A mainstream zenészek körében az individualitás zártabb rendszerben, tipikusan sztenderdjátékban fejeződik ki.

Rényi tanár úrnak (Rényi András művészettörténész - H.Á.) van egy, nekem nagyon tetsző megfogalmazása: az elvárási horizont nevü fogalom. Azt mondja, hogy a müvészetnek az a célja, hogy meglepetést okozzon, de azt teszi hozzá, hogy csak akkor tudunk meglepődni, ha van egy elvárási horizontunk.

Vagyis, ha egy jazz-zenész az individualitását úgy tudja megmutatni, ha azt olyan formában teszi, melyet mind a közönség és a jazz-zenészek egyaránt felismernek. A sztenderdjáték így tulajdonképpen egy esztétikailag megalapozott referenciarendszert jelent, amely alapot biztosít a legitim hierarchizáló különbségtételek megvonásához. Másrészt egy tudatos stratégia is a mainstream zenészek részéről a hierarchizálódási elv, vagy nomosz, kisajátítására és monopolizálására. A várakozási horizont fogalmának intellektualizáló terminusát koránt sem ismeri, vagy használja tudatoson a jazz-zenészek túlnyomó többsége.

${ }^{161}$ A várakozási horizont Hans Robert Hauss (1982) irodalmi recepcióesztétikájának egyik kulcsfogalma. A szerző irodalmi hermeneutikával kapcsolatos gondolatai itt terjedelmi korlátok miatt nem kerülnek kifejtésre. 
Mégis többről van szó, mint arról, hogy kutató a fősodratú jazz-t játszókra ráerőltetné a Jauss irodalmi hermeneutikájának skolasztikus kategóriáját, mert körükben a legitim különbségtételek - így a legitim ,jazzdefiníció” - viszonylag objektív kategóriák mentén realizálódnak, nem csupán a (szabad) improvizáción. Az ellentét relevanciáját jól szemlélti a két interjúrészlet kontrasztja: ${ }^{162}$

Mert nem stílus a jazz, hanem olyan emberek közössége, akik improvizálnak.

Improvizáló zenészek közössége? Ez hülyeség. Miért, ha lemegy valaki blues-t játszani, akkor az jazz?! Ha valaki nem játszik négyeshangzatokat, hogy lehetne rámondani, hogy jazz?

Egy koncerten vagy jammen pl. könnyen megfigyelhető az értékelés és elismerés, ha a hozzáértő jazzisták reakcióit figyeljük meg. Ha egy szólista „stenkben” van, a hozzáértő fülek tapssal, füttyel, vagy bekiabálással fejezik ki tetszésüket, a koncert után pedig jellemzően a mainstream körben - a „dögösnek”, „fainnak” dicsérik a stenkben lévő muzsikus játékát vagy „rázását”. ${ }^{163}$ A mainstream jazzen belüli objektív különbségtételek szociológiai rekonstrukciója céljából más zenészek konkrét játékáról is kérdeztem a zenészeket. Mikor arról kérdeztem egy zenészt, hogy a szóban forgó hangszeres játékát miért tekinti „,igénytelennek”, azt a választ kaptam, hogy a sokadik harmóniakör végén nem a cintányérral „ütött be”, hanem ,igénytelenül”, a pergő dobot használta. Ami a közönségnek egy nüánsz, melyet feltételezhetjük észre sem vesz, a szóban forgó zenész számára a taktus végének hangsúlyozását szolgáló „,beütés” hiánya már elég volt a dobos kategorizálásához.

A várakozási horizont kifejezéssel leírt mainstream esztétikai paradigmával szemben a szabad zene nem ad hasonló fogódzókat, ezért megítélése is sokszor ellentmondásos, egy olyan közegben, ahol - mint korábban említettük - a jazzoktatás csúcsintézményében, a Zeneakadémia Jazz Tanszékén, a fő oktatási paradigma az amerikai mainstream jazz elsajátítása. A szabad zene és free jazz esztétikáját a spontán kompozíció fogalmában célszerü megragadni, mely szakít tradicionális jazz „táncrendjével” és a teljes

${ }^{162}$ Az első interjúrészletet (név nélkül) felolvastam egy mainstream zenész interjúalanyomnak. A második idézet az erre való reakció.

163 Tipikusak még a „yes”, „yeah man”, ,jól dzsanázik”, „kijátssza a szemed”, „leszakítja a csillagokat olyat ráz” (vagy „virgázik” [virtuóz módon improvizál]) szófordulatok. A zenei felsőbbrendűség és dominálás tipikus kifejezései pl. a „fázik”, „megfázik”, „kifázik”, „csóró”, „nem tud semmit” fordulatok különböző variációi, melyeket a free zenészek többsége tudatosan nem használ, fogalmak szintjén is megteremtve a distinkciót a mainstream körtől. 
jelenidejüséget és az elmélyültség absztraktabb kategóriáját hangsúlyozza. A formáció tagjai azonos státuszban vannak, a szólistának kevésbé domináns a szerepe, mint a tradicionális jazzben, a körbeszólózás is eltűnik, vagy legalábbis nincs megszabva a sorrendiség. Magát az improvizáció fogalmát sem szívesen használják: „nem szeretem ezt a szót, hogy improvizáció, mert ma már mindenki improvizál" (Ráduly, 2015a). A mainstream jazz esztétikájának viszonylagos negligálása nem jelenti a különbségtétel relativizálódását a szabad zenében: egy szabadzenész pl. „hangcsinálásnak”, „zajongásnak” hívja az értéktelen szabadzenét és nem győzi hangsúlyozni, hogy számukra is meghatározó a „szakmai felkészültség”, a hangszeres tudás és az alapok elsajátítása. Fontos újra megjegyezni, hogy a párhuzamos tanszak toposzától eltekintve majdnem minden free zenész részesül(t) valamilyen formális oktatásban, mely tipikusan nem klasszikus, pop-rock, vagy népzenei képzést, hanem jazzoktatást jelent, tehát a mainstream- és free zenészek egyazon intézményi struktúrát lakják be. A szakmai elveken túl viszont az individualista, autonóm művész ideálja sokkal fontosabb számukra, mint a hangszeres tudás és mainstream zenészek „multistirális” szakmai ethosza és attitüdje, mely szerint egy jazz-muzsikusnak kell tudni játszani bossa novát és latint is.

Árulkodik a spontán kompozíció fogalmával leírt esztétikáról, hogy egy szabad zenei eseményen a koncertszervező zenész vezényelte az eseményt, ami meglátásom szerint szembe ment a stílus magáról alkotott szabad, jelen idejü, a zenészek státuszát tekintve egalitariánus normarendszerével. A kulisszák mögötti beszélgetés során kiderült, hogy egy zenekartag akkor kerül ilyen domináns, kvázi-karmesteri szerepbe, ha szétesik az összjáték, melynek kockázata egy szabad zenei eseményen jóval nagyobb, mint egy mainstream koncerten, ugyanakkor a műfaj esztétikai tétjét is ez a kísérletezésből, útkeresésből fakadó törékenység adja.

\section{10. Megélhetési stratégiák és a tevékenységtípusok hierarchiája}

A zenészek különböző megélhetési stratégiáira való utalás azért fontos dimenziója a jazzszcéna szerkezetét alkotó tényezőknek, mert a tevékenységtípusok hierarchikus viszonyt alkotnak, és strukturálják a közeget, vagyis a szcénán belül döntő szereppel bírnak a presztízsszerzésben. Umney és Krestos $(2013,2015)$ munkáival ellentétben, akik sajátos munkaerőpiaci szegmensként, kreatív munkavállaóként értelmezik a fiatal londoni jazzmuzsikusok megélhetési startégiáit, e fejezetben a cél inkább a különféle pénzkeresési módok és presztízsszerzés összefüggéseinek felvázolása. A megélhetési stratégiák 
bizonyultak az egyik leginkább releváns elemzési területnek a mezőként értelmezett jazzszcéna rétegződésének és a jazz-zenészek pozíciószerzéseinek szempontjából, ezért a klasszifikációs konfliktusokat bemutató fejezet után most ennek a szempontnak a bővebb kifejtése következik.

Vannak pénzkereseti források, melyek nem méltók a felkent jazz-zenész számára, s amelyeket a zenészek számos esetben igyekeznek eltitkolni, legalábbis saját körükön kívül. Ilyen tevékenységtípusok pl.: a „lagzizás”, youtube oktatóvideók készítése nem jazz műfajban, „vendéglátózás”, céges rendezvényen zenélés, vagy valamely „profán”, könnyü müfaj zenekari tagságának felvállalása. Ezzel szemben magasabb státusszal bírnak olyan elfoglaltságok, mint elsősorban a tanítás, viszonylag magas szintü zenei önmegvalósítást megengedő haknizás és zenei háttérmunkák, melybe a hangszerelésen kívül széleskörü, technikai jellegű munkák is beletartoznak, - pl. kottaíróprogramok ismerete. ${ }^{164}$ A következő, egyik szélsőséges mainstream vagy free pólushoz sem sorolható zenész emeli ki a tanítást, mint megélhetési tevékenységet szemben a jazz-zenész számára derogáló szórakoztató zenéléssel:

G: Nem vagyok hajlandó az időmnek azt a részét, amit zenével tölthetnék PR-al tölteni. Mert nem érdekel. Elég rövid az élet ahhoz, hogy én a zenéből minél többet megtanuljak.

H.Á.: Akkor miből tartod fent magad?

G: Tanításból. Akik nem tanítanak zenét csak a lagzi-szenvedés, rendezvényes, partin zenélés, hajó az egyetlen perspektíva.

Máskor kívülállók számára jóformán érthetetlen, komoly egzisztenciális viták tanúi voltam pl. arról, hogy az adott jazz-zenész bevállalhat-e tagságot magas anyagi juttatással járó populárisabb formációkban, összeegyeztethető-e ilyen esztétikai kompromisszum a jazzzenész pozíciójával, müvészi ethoszával és a szcénában domináns hierarchizálódási elvvel. Több, generációsan és müfaj szerint is különbözö interjúalany, külön kiemelte, hogy nem művészi (nem jazz-zenéhez köthető) tevékenységeit kifejezetten titkolja a jazz-zenészek előtt.

${ }^{164}$ A logisztikáért és in vivo technikai háttérmunkákért felelős road sajátos pozíciójára terjedelmi okok miatt nem térünk ki. A pozíció bennfentességet és fontosságát szemléltetendő mindössze azt jegyezném meg, hogy ebben a formában jelen értekezés sem jöhetett volna létre a tavaly elhunyt Balogh „road” Elemér hathatós bábáskodása nélkül, melyet ezúton is szívből köszönök neki. 
A Youtube-os oldalam is letiltattam Facebookon. Nem akarom, hogy (...) lássák, nekem ez pénzkeresés. Azt akarom, hogy ami a zenei profilom találják meg az emberek, ne a pénzkeresős dolgaimat.

A jazzszcénában a státuszhierarchia kialakulásának egyik kulcsszempontja a pénzkereseti stratégiák megítélése, mivel azok (szimbolikus) tőkeként is funkcionálnak. Így az alacsony státusszal járó tevékenységek eltitkolása egyben értelmezhető a kollektív szimbolikus szankciók elkerülésére irányuló aktusnak egy olyan müvészi piacon, ahol a gazdaságilag kényelmesebb megélhetéstípusokat negatív előjelü szankciókkal illetik az erőtér domináns pozícióit betöltő zenészek, pl. olyan látens módon, hogy a jazzélet centrumában lévő nagy presztízsű zenészek nem hívják játszani azt, aki adott esetben „profán” tevékenységekben szerzett magának hírnevet, pl. populárisabb zenei piacokon. Az erőteret domináló autoritások - különböző irányzatok és hangszerek nagy presztízsű zenészei, egyes oktatók és Zakos tanárok, különböző zenekarvezetők, de koncertszervezők - elvárásai is érzékelhető hatást gyakorolnak életpályájuk különböző fázisában lévő jazzistákra:

Annyira közvetlen hatással volt rám a közeg, az utóbbi 10 évben, hogy úgy érzetem, ha ettől a nyomástól nem tudok megszabadulni, hogy a szakma mit vár el, (...) akkor inkább abbahagyom.

A hangsúly a „közvetlen hatáson” van: a mezőben cselekvő domináns pozíciókat betöltő ágensek közvetlenül jelölik ki (az újonnan belépő) zenészek cselekvési horizontját, és ez által a szimbolikus és gazdasági profitszerzések logikáját. Ezért is müködtethető jól a mező fogalma a kortárs magyar jazzre vonatkoztatva, mert általa a különbözö ágensek stratégiáit nem valamiféle „okként tételezett létföltétel mechanikus következményeinek” (Hadas, 2009: 87) értelmezzük, hanem a mező mint sajátos tétekkel és szabályokkal bíró strukturált erőtér kontextusában működő gyakorlati érzék megnyilvánulásainak tekintjük (Maanen, 2009).

A budapesti színtér szimbolikus profitok és gazdasági profitszerzések ellentétéből fakadó inverz politikai gazdaságtanát árnyalja a hosszú és rövid távú megélhetési stratégiák közti különbségtétel. Ugyanis azt a zenészt, aki pályaíve során elegendő szimbolikus profitot (presztízst) halmozott fel pl. az által, hogy elismert formációkban játszott, jellemzően kevésbé érik negatív szankciók mikor populárisabb formációkban is megfordul pályája során. A fiatalabb, szcénába épp belépő zenészek esetében azonban hosszú távú megfontolást is igényel a megélhetés és presztízs - legtöbbször egymásnak ellentmondó szempontjaival való kalkuláció. Ha elég időt töltenek tőkefelhalmozással az erőtérben 
felismert, értékelt, státusszal bíró tevékenységek révén, és kevésbé láttatják egyéb pénzkereseti tevékenységeiket, hosszabb távon lehetőségük nyílhat konvertálni a felhalmozott presztízst gazdasági profitokra, például egy nevesebb formáció tagjaként, oktatóként, jam session házigazdaként, - vagy akár a felsorolt tevékenységek együttes gyakorlása révén. A középgenerációban jócskán benne járó muzsikus e stratégiának arról a fatalista visszásságáról beszélt, amikor zenészek túlságosan explicit módon határolódnak el a gazdasági profitoktól:

Hiú álomba ringattam magam azzal, hogy nem válltam el munkákat könnyebb müfajokban, aztán mire rájöttem késő volt, és mindenki azt hitte, hogy nem érdemes engem elhívni.

A kommersz sikertől való túlzott elhatárolódás, mondjuk így, a szimbolikus profitokat előnyben részesítő autonóm stratégia fatalista követése is járhat hosszabb távon negatív gazdasági szankciókkal. Mindazonáltal a két véglet - piaci és szimbolikus - ellentéte jól láttatja az egyéni stratégiákat kondicionáló erőtér sajátos logikáját és működését. ${ }^{165}$

Az autonóm-heteronóm pólus Bourdieu-től kölcsönzött oppozícióját (1993, 1996) tovább árnyalja, hogy az autonóm pólust betöltő (még a jazz közönségén belül is szűkebb körnek játszó) free jazz képes kialakítani egy intenzív koncertlátogató rajongói közeget, mely rendszeres játéklehetőséget biztosít számára, és amelyet maguk is úgy érzékelnek, hogy „,nem játszanak kevesebbet”, mint a mainstream zenészek. ${ }^{166}$ Ez a jelenség összefügg az erőtér rétegződésével, ugyanis a free jazz, avantgárd és szabad zene, professzionális mainstream és a fent említett kommerciális („híg”) jazz között meghúzott koordinátarendszerben a legnagyobb verseny középen van, tehát valamely mainstream irányzathoz köthető, befogadói szemszögböl leginkább „fogyasztható”, „dallamos”, „virtuóz”, „érthető” „technikás”, „szép”, „szvinges” stb. jelzőkkel leírt formációk és

${ }^{165}$ Ez a jelenség összecseng Umney és Kretsos (2013) fiatal londoni jazz-zenészekről folytatott kutatásával. Egyik fö következtetésük ugyanis az, hogy a kreatív autonómiára való törekvés, a „fatalizmus”, kerékkötője a kollektív érdekérvényesítésnek, így a viszonylag rossz munkakörülmények egyik fő oka. Egységes gázsikról pl. nem beszélhetünk; helytől, rendezvénytöl függően 5-50 ezer forintos fejenkénti összeget kapnak a zenészek, klubbulinként pedig átlagosan 10-15 ezer forintos egy főre eső gázsival.

${ }^{166}$ A free zenészek jellemzően intimebb hangulatú helyeken játszanak kisebb, de intenzívebb preferenciákkal rendelkező magas szubkulturális (mezőspecifikus) tőkével bíró közönségnek (Thornton, 1995), míg a „középutas” mainstream jazzt játszó muzsikusokra inkább jellemző, hogy preferencia szempontból is rétegzettebb, kevésbé homogén közönségnek játszanak. A két stílus térbeli elkülönülését jól jelzi, hogy az egyik legközismertebb free zenekarnak nyaranként szinte nincsen „bulijuk”, a mainstream zenét - szélesebb közönséget célzó jazzt - játszókkal sokszor interjút is nehéz volt egyeztetni a nyári fesztiválszezon miatt. 
csoportok között. Így a szűkös erőforrásokért folyó küzdelmek általában a generációsan viszonylag vegyes, szakmailag komolyan felkészült, professzionális zenészek közt folynak, és nem az autonóm pólust - néhány interjúalany szerint - esetenként „,underground sztárként" monopolizáló, csekély számú free zenészek és mainstream muzsikusok közt a magyar jazz-piacon. E tekintetben Kacsuk (2015) azon észrevétele nagyon is idevág mikor rögzíti, hogy mind Kahn-Harris (2007) az extrém metál szcéna és Hodkinson (2002) a goth szubkultúrával kapcsolatos kutatásaik során azt figyelték meg, hogy a verseny a piac erőinek jobban kitett csoportok felé haladva intenzívebb.

A megélhetési stratégiákat budapesti közegben is tipizálhatjuk. Egészen az olyan autonóm zenészektől, akik elsősorban saját kompromisszum nélküli müvészi projektjeikből élnek meg (vagy helyesebben: próbálnak megélni), ${ }^{167}$ azokig, akik különféle esztétikai kompromisszumokat kötnek, a tanítást mint legitimitáshierarchia csúcsán lévő kereseti tevékenységet leszámítva populárisabb müfajokra helyezik a hangsúlyt; leginkább mint alkalmazott, vagy vendéglátós „haknizenészek”, és nem mint - freejazz-szóhasználattal élve - autonóm, kompromisszumot nem türő művészek tevékenykednek. ${ }^{168}$ „Haza is mennék ha megmondanák mit kell játszanom." - válaszol arra a kérdésre a magát szabadzenésznek valló müvész, hogy játszana-e vendáglátóhelyen, ahol előfordulhat, hogy a közönség elköveti azt, ami legtöbbször a muzsikusok kifejezetten utálnak: számot kér a tőlük. ${ }^{169}$ A szélsőséges piaci elvárásokat a mainstream jazzt játszók nagyrésze is elítéli, sőt a vendéglátós attitüd sokszor vicc tárgyát képezi. Mikor az egy általam szervezett koncerten megjegyeztem, hogy „percre pontosan végzett a zenekar” a gitáros gúnyosan odaszólt a szaxofonosnak: „Nagy vendéglátós $a(\ldots)$ ”. A free és mainstream csoport egyaránt elítéli a puszta szórakoztatásra szánt jazzt, a különbség mégis abban áll, hogy a legtöbb free zenész nem megy el közepesen jó (fejenként 15 ezer forint, vagy annál több) gázsiért kávézóba háttérzenét játszani, ha nincs kifejezetten rászorulva. Az autonóm pólussal szemben álló, közönség igényének

\footnotetext{
${ }^{167}$ Néhány kivételtől eltekintve az autentikus csoportba sorolt zenészek jellemzően tanítanak és/vagy zenét szereznek filmhez, színházhoz.

168 A különböző hangszeresek egyébként izgalmas piacát itt nem elemzem.

169 Ha csak nem egymásnak játszanak. Egy jazz muzsikusokkal és aktív, a szcénában felismert, tehát színtérspecifikus tőkével bíró rajongóelittel teletömött helyen kifejezetten a zenészek kérték a közönségtől, hogy ajánljanak számokat játékra. A számkérés elítélése tehát nagyban függ az adott közeg helyi értékétől vagy presztízsétől a szcénában. Különböző közönséget és müfajokat felvonultató helyeken izgalmas volna etnográfiai módszerekkel tanulmányozni a közönség-zenész interakciókat, már csak a fenti példa illusztratív ereje miatt is, mely a közönség és helyek státuszviszonyainak összefüggéseiről árulkodik.
} 
kielégítésére specializálódott irányzatot hívták több helyütt is „híg jazz-nek”, „ipari jazznek”, „zenei szakmunkának”, „rabszolga zenének”. 170

A szélesebb közönségnek játszó fősodratú jazz is differenciálódik a szerint, hogy az illető igényes háttérzenét játszik, saját szerzeményekkel, vagy direkt a közönség számára tett gesztusokkal hígítja fel a stílust, mely szimbolikus státuszát tekintve a légértéktelenebb tevékenység a szcénában. A jazz-zenészek státuszát tovább differenciálja, hogy a saját zenei projekten kívül - mely, ahogy az 1 . ábra is szemlélteti a tevékenység legitimitáshierarchiájának csúcsán áll, ha megélhetést is biztosít - az egyéb, másodrangú, megélhetéshez szükséges tevékenységek megítélése. Itt a haknizás és tanítás oppozíciója meghatározó és jellemzően a tanítás számít nagyobb presztízsü tevékenységnek, melyet az 1. ábra 2. és 3. pontja illusztrál.

Alapvetően kétféle zenész van. Az egyik, aki mindenféle zenét elvállal (olyanokat is, amiket egyébként nem szeret), viszont nem tanít mellette. Így a haknizásból tudja megteremteni esetlegesen a saját zenekarra (...) az alaptőkét. Van, aki pedig azt mondja, hogy csak a saját zenekarát és zenéjét csinálja (jó, mondjuk nem csak, de főleg azt) és mellette tanít három napot. (...) Én inkább az vagyok, aki sok mindent elvállal. Jobban szeretek játszani, mint tanítani. Engem jobban szórakoztat, és szerintem könnyebben is lehet így pénzt keresni. Meg nem is zavarnak az olyan szituációk, hogy lagziban kell játszani (...). Sok mindenkit zavar. ${ }^{171}$

170 „Ezt semmi sem különbözteti meg attól, hogy valaki kiteszi a mellét. Ez pont ugyanaz a szememben. Tehát nem egy mély müvészi megfontolás eredménye, hanem egyfajta piaci rés betöltése."

„Vannak olyan zenészek, akik alkalmatlanok, idézőjelben mondom, ők a közmunkások, akik játszanak sztenderdet, latint, szvinget, mindenfélét, de ha azt mondod irj egy új számot nem tudnak. Viszont, hogy a nagyközönség megismerje a müfajt, ahhoz elengedhetetlen, hogy tudjanak latint játszani szvinget, tehát erre szükség van."

${ }^{171}$ Az interjúrészletet Szabó (2014: 56) szakdolgozatából vettem át. 


\section{1. Ábra: Zenei stratégiák legitimitáshierarchiája}

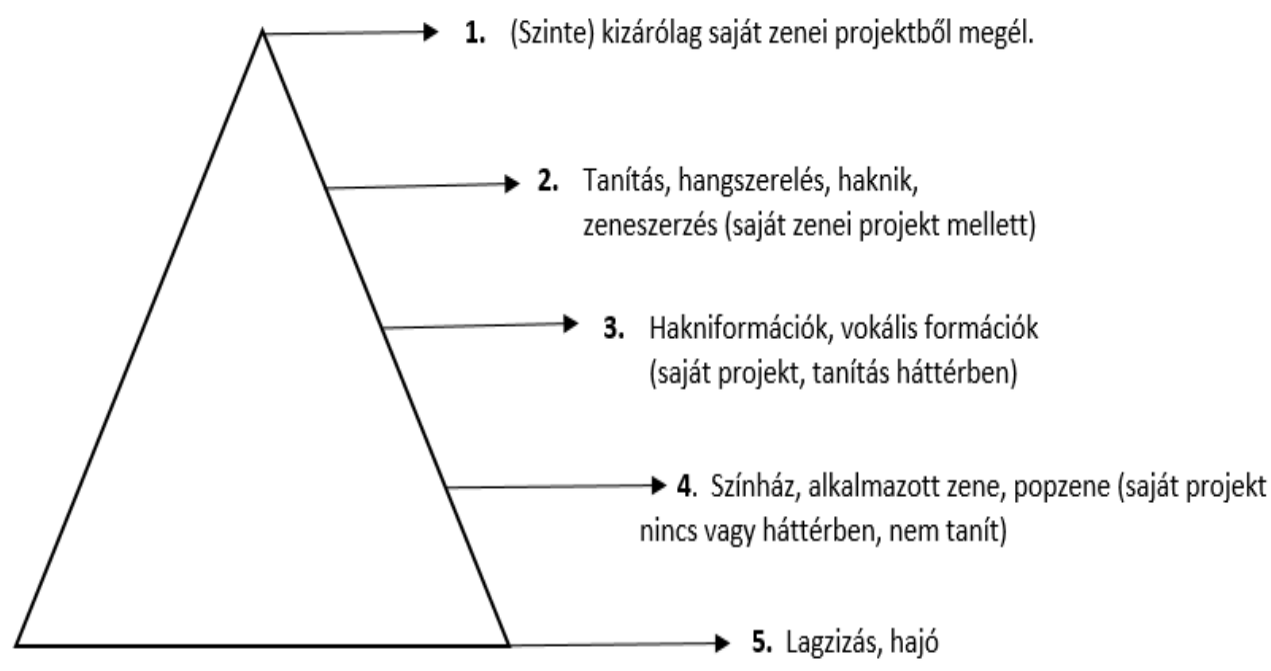

A megélhetési stratégiák, mint láttuk egyaránt összefüggésben állnak a presztízsszerzéssel és a zenei identitáskonstrukciókkal, mely a negatív definícióból („mi nem vagyok”) levezetett megkülönböztetés és kizárás egyik fontos aspektusa. A szabadzenészek például az interjúk során kihangsúlyozzák, hogy „egy kezükön meg tudják számolni, hányszor zenéltek pusztán a pénz miatt" és nem egyszer ezen ritka eseteket hosszasan magyarázzák, legtöbbször az akkor épp szorult anyagi helyzetükkel, míg a tradicionális zenét játszó körre a fenti attitüd inkább nem jellemző: a jazz-zenész „mint hivatás” velejáró részének tartják a rendezvényeken, haknikon zenélést, médiaszereplést, így a multitasking-ot. A generációs dimenzió külön nem képezte vizsgálódás tárgyát, épp mert történeti és intézménytörténeti szemszögből lenne érdemes kutatni a hosszabb távú pályaívek alakulását beleértve a jazzzenészek mint kreatív munkavállalók multipozicionalitását is. Ugyanakkor a következő interjúrészletek tartalmi elemei olyannyira gyakran bukkantak fel az interjúk és beszélgetések során, hogy érdemesnek találom közölni:

Elég nagy különbség van azok közt, akik abba született be, hogy hívták (játszani), volt rengeteg lehetőség, normálisabb gázsik... a gázsik ott maradtak ahol 15 éve voltak, a lehetőség sokkal kevesebb lett... aki abba született be, hogy volt bulija annak sokkal nehezebb változtatni ezen, mert már változtatni kell. Nekünk ez a nulla, ez a megszokott. 
További, tartalmilag szinte teljesen azonos interjúrészletek citálása nélkül is (pl.: „ez egy elégedetlen közeg, mert nagyon sokuknak nem sikerül karriert csinálni”, „zseniális zenészek, és ezért frusztráltak”) egyértelműen kiderül, hogy a szakmai képzettség, sikerek és intézményes, gazdasági megbecsülés észlelt aránytalansága, valamint a hatékony kollektív érdekérvényesítés hiánya a magyar jazzban jelenlévő „rossz közérzet” egyik fő oka.

\section{11. A kérdőíves kutatás eredményei}

Mint már korábban említettem, korlátozott erőforrásaim miatt nem volt lehetőségem arra, hogy megfelelő elemszámú reprezentatív mintával dolgozzak, így Ser Ádámmal közösen készített illusztratív, feltáró jellegü kvantitatív elemzésünket csupán két budapesti intézményben végzett kérdőíves kutatásra tudtuk alapozni. ${ }^{172}$ Ezt végig szem előtt tartottuk, így a kérdöívekkel nem a statisztikailag szignifikáns oksági összefüggések kimutatását céloztuk, hanem azt, hogy betekintést nyerjünk a szcénába frissen belépő vagy csak belépni készülő fiatalok percepciójába azt a közeget illetően, melyben maguk is különböző pozíciók betöltésére vállalkoznak mint diákok és egyetemi hallgatók. Az ő esetükben úgy gondoltuk, fontosabb, hogy minél több ember véleményét megismerjük, mint az, hogy minél mélyebben megismerjünk egy adott véleményt, ${ }^{173}$ ezért döntöttünk úgy, hogy a kvalitatív, mélyinterjús kutatást kérdöívezéssel egészítjük ki, és ahol ezek alapján tendenciózus összefüggéseket állapítunk meg, ott nemzetközi kontextusba is ágyazzuk azokat. A következőkben a társadalmi háttér, a gazdasági és müvészeti célok között feszülő konfliktus, a müfajon belüli distinkciók és az etnikai dimenzió kérdéskörét érintem.

A kérdőívet 37 ember töltötte ki, közülük 10 nő és 27 férfi, 12 az ETÜD Zenei Konzervatórium, 25 pedig a Liszt Ferenc Zenemüvészeti Egyetem hallgatója. Az átlagéletkor 25 év, a legfiatalabb válaszadó 20, a legidősebb 41 éves. Szinte mindegyikük Budapesten él, a válaszadók majdnem fele ott is született. Hárman vannak, akik a hangszer

${ }^{172}$ Az ETÜD Zeneiskola és Zeneművészeti Szakközépiskola és a Liszt Ferenc Zeneművészeti Egyetem Jazz Tanszékén végeztünk kérdőíves kutatást, tehát a zenei képzés középszintü (ETÜD) és felsőfokú (Liszt) intézményeiben.

${ }^{173}$ A kutatás kvalitatív elemzését a budapesti jazzszcéna kollektív reprezentációjáról és a free-mainstream jazz ellentétéről lásd bővebben pl. Havas (2017a) munkájában. 
mellett énekelnek is, és szintén hárman, akik csak énekelnek. Mind a hatan nők. A megkérdezettek több mint egyharmadának volt zenész a családjában. A jazz-zenészek társadalmi hátterét tekintve nagy kérdés volt, hogy a magyar szcéna inkább az Umney és Kretsos (2015) által leírt angolhoz hasonlít, amelyben belépési korlátként tekinthetünk a középosztályi háttérre, hiszen a család anyagi támogatása nélkül szinte lehetetlen jazzzenésszé válni, vagy pedig a Dowd és Pinheiro (2013) által bemutatott amerikaihoz, ahol bárkiből lehet jazz-zenész. Az önbesoroláson alapuló osztály-hovatartozást tekintve úgy tünik, hogy a diákok dominánsan középosztályi háttérrel rendelkeznek mindkét intézményben, a válaszadók között egyetlen ember van, aki a munkásosztályhoz sorolta magát. Ez arra utal, hogy a magyar jazzszcéna ebből a szempontból inkább az angolhoz, nem pedig az amerikaihoz hasonlít. A megkérdezettek szüleinek iskolai végzettsége is ugyanezt sugallja, hiszen mind az édesanyák, mind pedig az apák esetében 50\% feletti a felsőfokú végzettségűek aránya, ami jóval meghaladja a társadalom egészében megfigyelhető arányt.

Térjünk át a müvészi és gazdasági érvényesülés konfliktusának témakörére. A válaszadók túlnyomó többsége úgy érzi, hogy az intézmény, amelyben tanul, biztosítja számára a megfelelő szintű zenei felkészültség elsajátítását, egybehangzó vélemény volt azonban az is, hogy egy jazz-zenésznek a zenei felkészültségen kívül szüksége van egyéb kompetenciákra is. Ezen a területen azonban már korántsem tökéletes a képzőintézmények megítélése. A diákok egyharmada nem érzi, hogy az iskola elősegítené számára a megfelelő szakmai kapcsolatok kialakítását, és csak körülbelül egyötödük érzi úgy, hogy az intézmény bármilyen mértékben fejleszti az anyagi siker eléréséhez szükséges képességeit. A két intézmény esetében hasonló mintázatot figyelhetünk meg, azonban meg kell említenünk, hogy a Liszt Ferenc Zenemüvészeti Egyetem tanulói minden szempont esetében rosszabb értékelést adtak, mint az ETÜD diákjai.

A megkérdezettek egybehangzóan úgy gondolják, hogy a jazz-zenészek között csak egy szük réteg van, aminek a tagjai képesek kizárólag a fellépésekből megélni, azonban a megkérdezettek körülbelül egyötöde úgy véli, hogy tanulmányai elvégzése után ő maga ehhez a szerencsés kisebbséghez fog tartozni. Tapasztalataik szerint a jazz-zenészek jellemzően egyéb, zenéhez kötődő munkákat vállalnak, hogy fenntartsák magukat, olyan munkákat, mint például a tanítás, színházi zenélés vagy hangolás. Amikor a diákok a saját megélhetésükről nyilatkoztak, ennél jóval sokszínübb kép tárult elénk: jellemzően kisebbségben voltak a zenéhez kötődő tevékenységek. Ellenben megemlítik például a modellkedést, az adminisztratív munkát vagy éppen a gyerekfelvigyázást, de biztonsági ôr (!) is szerepel a válaszok között. Hasonló különbséget figyelhetünk meg annál a kérdésnél, 
ami azt firtatja, hogy van-e konfliktus a müvészi önmegvalósítás és az anyagi siker között. Az általános kérdésnél szinte mindenki úgy gondolja, hogy fennáll ez a konfliktus, a saját életével kapcsolatban viszont a megkérdezettek egyötöde nem érzi ezt.

Az eddig említettektől eltérően a „müvészi szempontból nem értékes” fellépésekkel kapcsolatban nagy összhangot tapasztaltunk az általános benyomás és a személyes tapasztalat között. A megkérdezettek körülbelül fele úgy gondolja, hogy természetes, ha egy jazz-zenész olyan fellépést is vállal, amelyet nem tart müvészi szempontból értékesnek, szintén a megkérdezettek fele nyilatkozott úgy, hogy neki magának volt már szüksége arra, hogy ilyen fellépést elvállaljon, körülbelül egyharmaduk nyilatkozott úgy, hogy nem ért egyet az ilyen fellépések szükségességével, és szintén egyharmaduk érezte úgy, hogy neki személyesen nincs szüksége ilyen fellépésekre.

Arról is megkérdeztük a diákokat és hallgatókat, hogy milyen tényezők járulnak hozzá a müvészi célok és az anyagi siker közötti konfliktushoz. A válaszadók körülbelül egyharmada gondolta úgy, hogy a konkurencia hozzájárul ehhez a konfliktushoz, felük gondolja ugyanezt a szakmán belüli összefogás hiányával kapcsolatban, abban pedig szinte kivétel nélkül egyetértenek, hogy az alacsony gázsi hozzájárul a konfliktushoz. Néhányan egyéb okokat is említettek, többen panaszkodtak a rajongóközönség alacsony létszámára, de felmerült a szakmai alázat hiánya is. A válaszadók többsége a siker kulcsának a jól működő marketinget tartja. Ezenkívül a válaszadók körülbelül negyede gondolja úgy, hogy a sikerhez professzionális háttérrel jó minőségű zenét kell alkotni, ugyanakkor nagyjából ugyanennyien nyilatkoztak úgy, hogy az igénytelen, közönség megnyerésére alkalmas silány és egyszerü zene vezet a sikerhez.

A müfajon belüli distinkciók tekintetében az interjúk alapján azt a tanulságot vontuk le, hogy a legnagyobb szakadék a free és a mainstream jazzt játszók között húzódik. A kérdőívek kitöltői közül körülbelül a megkérdezettek fele említette a free-t mint jazzen belüli irányzatot, valamivel kevesebben említették a mainstream kifejezést, azonban szinte mindenki említett a mainstreamhez tartozó szerkezeti-stiláris szempontokat, például a szvinget vagy a bebopot. Arra a kérdésre, hogy vannak-e egymással szembenálló irányzatok, a válaszadók negyede említette a free-mainstream ellentétet. A válaszok alapján általánosságban azt mondhatjuk, hogy a válaszadókhoz nem áll igazán közel a free jazz, mind a legsikeresebb előadókra vonatkozó, mind pedig a személyes kedvenc iránt érdeklődő kérdésnél szinte mindenki mainstream előadókat említett, és csak egy-két válaszadó nevezett meg freejazz-zenészt, ahogy a műfajok esetében is csak ketten mondták, hogy a free áll közel hozzájuk - mindenki más mainstream müfajokat említett. Ehhez képest csak a válaszadók 
fele ért egyet a mainstream zenészek által hangoztatott jazz-zenész definícióval, miszerint csak azt nevezhetjük jazz-zenésznek, aki elsajátítja a '40-es évek Amerikájában kialakuló jazz-zenei „nyelvezetet”: a szvinges lüktetést, a kötött harmóniakör alapján kibontakoztatott sztenderdjátékot és elsajátította a jazzes frazeálást vagy előadásmódot is. Ezzel szemben szinte mindenki egyetért azzal, hogy a jazz inkább a szabad önmegvalósításról szól, amit kifejezetten a free zenészek hangsúlyoznak.

A megkérdezettek szinte kivétel nélkül úgy gondolják, hogy létezik kimondottan „roma jazz”, azt azonban nem definiálták, hogy egy elkülöníthető stílust értenek-e a kategorizáció alatt vagy pusztán roma származású zenészeket. Ennél is fontosabb, hogy akik úgy gondolják, hogy létezik egy elitréteg a jazzen belül (ez nagyjából a válaszadók felét jelenti), túlnyomó részben a romákat nevezték meg elit csoportként, emellett sokan úgy nyilatkoztak, hogy bizonyos roma zenészeket egyfajta „sztárkultusz övez”. A megkérdezettek egy kisebb hányada nem szimpatizál ezzel a csoporttal, ők úgy gondolják, hogy a „roma kör” kirekesztő, elitista, és ellentéteik vannak más csoportokkal.

\section{12. Összegzés és vita}

E hosszabb fejezetben a magyar jazzélet egyik legmeghatározóbb strukturális sajátosságát: a free és mainstream jazz oppozíciójának különböző jelentéstartalmait elemeztem. Tettem ezt azért, mert a 2014 ösze óta tartó jazzkutatás tanulságai alapján, ez a zenei identitásokkal szorosan összefüggő alapellentét bizonyult, a távolabbról talán nagyon is banálisnak tünő kérdés egyik fő szegmensének: Ki számít ma jazz-zenésznek Magyarországon? A két irányzat egymáshoz való viszonyát olyan rendszert alkotó alapoppoziciónak értelmeztem, amely magában foglalja a legitim jazz-zenész definíciójának el- és kisajátításáért folytatott szimbolikus küzdelmek legfontosabb tétjeit és alapelveit, melyet az első táblázat ellentétpárjai által alkotott értelmezési mező próbál rendszerszinten megragadni.

Az elemzés maga, az alapdichotómia részeként kibontakozó zenei diszpozíciókkal és esztétikai elvekkel kapcsolatos ellentéteket kontextualizálta olyan főbb releváns szempontok szerint, mint a jazztradíciókhoz való viszony, a mainstream és free jazz esztétikai konstrukciói és az ezzel kapcsolatos legitimációs konfliktusok, a csoportok belsö viszonyrendszere és dogmatizmusa, és az ebböl fakadó zenei kirekesztés és elszigetelödés (önszegregáció) kérdéskörei. Az interjú-interpretációra és önreflexív terepmegfigyelésekre épülő „mélyfúrás” során, a két irányzat bináris oppozíciói szerint strukturált erőteret a bourdieu-i mezőkonstrukcióval elemeztem. Az elmélet relacionális logikája egy sajátos 
nézőpont abszolutizálása helyett, a pozíciók közti viszonyokra helyezi a hangsúlyt. Így a különbségtételre használatos fogalmak azonossága - mint láttuk - például elfedi az alkalmazásmódok közti meghatározó különbségtételeket, vagyis azt, hogy a különböző nézőpontból beszélő jazz-zenészek azonos fogalmak (,önmagad játszása”, „kreativitás”, „progresszió” stb.) eltérő alkalmazásmódjaival alkotják meg zenei identitásukat, és egyben a distinkciót a másik irányzatot képviselő zenészektől.

A szcénában a presztízs elosztásának monopolizálásért folytatott küzdelmek logikáját a szimultán esztétikai hierarchia koncepciójával ragadtam meg, mert a vizsgált a szcénában a piaci erők mellett két, magas státusszal bíró, egymással ellentétes hierarchizálódási rendszer alapvetően meghatározza a belépő zenészek cselekvési univerzumát: Ki itt belépsz... alkoss együttest, járj le egyik klubba vagy a másikba, használj bizonyos kifejezéseket, vagy ne, fújj egy melódiát a szaxofonodon - vagy más hangszeren; pengess, fújj, billents, dobolj - és máris részese vagy egy olyan erőtérnek, ahol a zenei kvalitásaid mellett a fenti döntéseid fogják meghatározni „mennyit is érsz”, kik fognak elhívni játszani, kikkel tudsz „,bulit kötni” és ami talán a legfontosabb, azt, hogy mely csoportok értékelési sémái fognak dönteni a zenei presztízsről. A mainstream és free esztétika dogmatikus, ideologikus képviselete, mindkét oldalról az igaz (jazz) zene piedesztáljára emeli magát, azonban a free jazz esztétikáját képviselők számára nem a jazz-zenész státusza, hanem az autonóm mủvész ideálja bír kiemelt fontossággal, ezért számukra a mainstream jazzben kulcsfontosságú tudástípusok és készségek elsajátítása kisebb - de koránt sem jelentéktelen - fontossággal bír. A jazz legitim definíciójának elemzése során, az 1. táblázat oppozícióinak statikus képét árnyalva a különböző irányzatok belső differenciálódását is elemeztem, melyből kiderült, hogy a két csoport egymásról alkotott leegyszerüsítő, kollektív doxájával ellentétben cseppet sem homogén csoportokról van szó.

A fejezet során az 1. táblázatban foglalt 13 szempontot nem volt lehetőségem kimerítően elemezni, pedig árnyalták volna az alapdichotómia strukturáló erejét és a hozzá köthető különböző pozíciók legitimitásküzdelmeinek dinamizmusát. Továbbá, a bevezetőben felsorolt hátrányain kívül azt is érdemes megjegyezni, hogy az elemzés során a két csoport szélsőséges képviselői közti ellentétek interpretálása nagyobb hangsúlyt fektettem, mint a jazzszcéna többségét adó „középutas zenészek” pozíciószerzéseinek és osztályozási sémáinak vizsgálatára. Mindazonáltal bízom benne, hogy az erőtérként értelmezett magyar jazzszcéna szerkezetét és rétegződését alapvetően meghatározó oppozíciót, a mainstream és free jazz ellentétet kellő elmélyültséggel és objektivitással ábrázoltam. 


\section{A KORTÁRS JAZZ ESZTÉTIKAI ÉS ETNIKAI KONSTRUKCIÓI: „CIGÁNY JAZZ” ÉS ZENEI HABITUS}

„,Nem kell Amerikába kimenni jazzt tanulni, (...) menjetek el a 8kerbe és megtanultok a Kálcsitól zongorázni, ennyi. ",174

\section{1. Bevezető megjegyzések}

A Youtube-comment idézetként való beemelése talán szokatlan felütésnek hat egy tudományos munkában, ${ }^{175}$ mégis, a szóban forgó kompozíció alatti hozzászólásban több olyan szempont lelhető fel, melyeket e fejezet során bontok ki, és amik szorosan kapcsolódnak a magyar ,jazz diaszpórával” (Johnson, 2002a) kapcsolatos kutatási kérdéseimhez. A több szempontból is kényes témafelvetés elején - kezdve az egyes zenészek témával kapcsolatos érzékenységétől, a müfaji besorolás problematikáján át, a számos zenésszel személyes viszont ápoló objektivitásra törekvő kutató sajátos pozíciójáig - fontos tisztázni, hogy a címben szereplő idézőjel egy tudatos gesztus, mely a konstruktivista elemzői szemléletnek kíván nyomatékot adni. Koránt sincs ugyanis konszenzus arról, hogy létezik-e „cigány jazz”, a '30-as évek Franciaországában kialakuló Django Reinhardthoz köthető „manouche jazz”, „gypsy jazz”, vagy „,szinti szving” néven is ismert zenetudomány és kultúrtörténet által kanonizált irányzatán kívül (lásd pl. Dregni, 2004).

Az alábbi fejezet a jellemzően többgenerációs zenészcsaládban, városi környezetben nevelkedett, a magyarországi cigányság döntő többségét adó „magyarcigány”, vagy romungró $^{176}$ származású jazz-muzsikusok zenei/esztétikai diszpozícióinak vizsgálatát tűzi ki célul. Az erőteljesen fővárosban koncentrált kortárs magyar jazzszcéna szimbolikus és gazdasági dimenziók mentén korábban részletesen vizsgált rétegződésében és hierarchikus viszonyaiban az etnicitás történeti és strukturális okoknál fogva sajátosan jelenik meg (Jávorszky, 2014; Retkes, 2014; Zipernovszky, 2017; Havas, 2017a). Egy rövid, kontextualizálás céljából beleillesztett történeti fejezetet követően, az empirikus részekben a zenei habitus három meghatározó, zenei szocializációval, életstílussal és esztétikai

\footnotetext{
174 Az idézet a Liszt Ferenc-díjas Oláh Kálmán „Kálcsi” (jazz)-zongoramüvész Always című, neves nemzetközi díjat is elnyerő kompozíciója alatti youtube-comment szerkesztett verziója. Az eredetit lásd: https://www.youtube.com/watch?v=H9ytdSvMEnU

${ }^{175}$ A fejezetre épülő azonos címet viselő tanulmányom (Havas, 2018b) a Szociológia szemlénél épp „megjelenés alatt” fázisban van.

${ }^{176}$ Arányuk a teljes cigány népesség 80\%-a (Kovai, 2015: 9).
} 
distinkciókkal összefüggő aspektusait elemzem. Az elemzés során az 5 „folow up” interjút nem számítva arra a 7 interjúra támaszkodom, melyet különböző generációba tartozó és eltérő hangszereken játszó roma zenésszel készítettem. ${ }^{177}$

A kulturális distinkciók diszkurzív konstrukcióiból kiinduló megközelítésem szerint a „cigányság” kulturális reprezentációja a legitimitáshierarchiák különböző szintjein (pl. a mulatós zenétől a klasszikus zenei referenciákig) egy folyamatosan újradefiniálódó, performatív és a stílusok keveredése folytán poliszémikus jelentéstartalmakkal átitatott jelenségegyüttest alkot, melynek sajátos szegmensét képezi a jazz mint populáris és klasszikus zenei gyakorlatokat és jelentéseket egyaránt magába olvasztó „hibrid” müfaj (Lopes, 2002). ${ }^{178}$

\section{2. A jazz-zenei mező felemelkedése és a muzsikuscigányok}

\section{2. 1. Zenészcigányok a legitimációs erötérben, avagy hogyan kerülnek a kávéházból a} (müvészetek) palotájába?

Kulcsfontosságúnak tartom röviden felvázolni a cigány muzsikusok és jazz viszonyának témafelvetéseim szempontjából meghatározó történeti aspektusát. A jazz térnyerése Magyarországon nem volt konfliktus nélküli. A többségi társadalom szórakoztatását monopolizáló cigányzenét, vagy magyarnótát (Brown, 2000: 124; Schneider, 2006: 24 29) ${ }^{179}$ játszó városi cigányzenészek kollektíve lázadtak fel az Amerikából beszivárgó és a városi környezetben szintén népszerű, gazdasági konkurenciát jelentő jazz-szel szemben (Zipernovszky, 2017). A gazdasági érdekkonfliktus mellett a jazz térnyerése a nemzeti kultúrára való veszélyként jelent meg, és a kulturális amerikanizációval fenyegetett. A társadalom félperifériáján lévő, ,,szignifikáns Másik” muzsikus cigányság, a nemzeti kultúra védelmezőjeként lépett fel a racializált (Federmayer, 2017 [2011]), „külső Másikkal”

\footnotetext{
${ }^{177}$ Szociológiai nézőpontból a „cigánykutatásokkal” kapcsolatos strukturális és kulturális diskurzusokról lásd (Ladányi, 2004; Ladányi és Szelényi, 2005; Stewart 1994). A kulturális antropológia és zenetudomány szemszögéböl pedig lásd pl. Kovai, (2015), Kovalcsik (2006) és Könczei (2011) munkáit.

${ }^{178}$ A zene szerepéről és a különböző stílusok jelentéstartalmairól a cigányság körében részletesen lásd (Kovai 2015: 59-73) és Stewart (1994) írásait, akik elsősorban a vidéki szegregátumokban „gettókban” élő cigányságra koncentráltak vizsgálódásaik során.

${ }^{179} \mathrm{~A}$ vidéki léthez köthető autentikus magyar népzene és elsősorban urbánus közegben kialakuló cigányzene, vagy „magyarnóta” közti tudományos különbségtételt a néprajzkutató Vikár Bélához, Bartókhoz és Kodályhoz köti a zenetudományi szakirodalom (Zipernovszky, 2017: 67).
} 
szemben, melyet az amerikai feketék jelentettek. Míg a felszentelt komolyzene a schonbergi atonális és Sztravinszkij-féle neoklasszicizmus irányvonalai között polarizálódott, addig az épp intézményesülő populáriszenei-mezőt részben a fenti racializált-etnicizált státuszküzdelem határozta meg két szignifikáns „Másik” között (Brown, 2000).

A szving aranykorának is hívott koalíciós időszak utáni államszocialista korszak '50es éveit a központi tiltás jellemezte, a jazzt ideológiailag konstruált jelzők mentén dekadensnek bélyegezték, a megélhetés szempontjából létfontosságú vendéglátó és közösségi helyek többségéröl - kávéházakból, éttermekböl - kitiltották. Enyhülés a '60-as években volt tapasztalható a kultúrpolitika részéröl: a populáris zenei iránti növekvő tudományos érdeklődés (Barna és Tófalvy, 2017) és a jazz-zenészek autonómiatörekvései nyomán a szocialista blokkon belül végül Magyarországon alakult meg az első Jazztanszak 1965-ben, noha a kulturális legitimáció olyan releváns indikátorai felől nézve mint a nagy presztízsű állami díjak odaítélése és a médiareprezentáció még ekkor is egyértelmű a műfaj periférikus helyzete.

A relatív autonómiával bíró jazz-zenei mező kialakulásával párhuzamosan (szakmai szervezetek létrejöttével, tudományos munkákkal, folyóiratok alapításával, fesztiválok és jazzklub-hálózat kiépítésével stb.) a szcéna a '70-es évektől kezdve egyre erőteljesen kezdett el polarizálódni ${ }^{180}$ mainstream és free jazz táborok között. Bourdieu terminusával élve a „mező eretnek átalakítása” (Bourdieu, 1993: 42) a mezőspecifikus tőkék létrejöttével és differenciálódásával, valamint a különböző legitimációs elvekből merítő zenészek közti státuszküzdelmek intézményesülésével ragadható meg. A Jazz Studium DIY kiadvány (1982-1990) pl. a free jazz hagyományt népszerüsítette és kanonizálta Magyarországon, de a győri '82-es fesztivál, melyen Szabados György először találkozott a neves amerikai freejazz-zenész Anthony Braxtonnal jól reprezentálta a free/mainstream különbségtétel intézményesülését. E distinkció társadalmi és etnikai különbségeket is megtestesített, melyet jól láttat a romák növekvő aránya mainstream jazz-ben, míg a Szabados értelmiségi és free jazz/avantgárd köre dominánsan a középosztályból szerezte társadalmi bázisát. Összefoglalva, a fenti distinkció társadalmi alapját a profetikus személyek körül csoportosuló eltérő osztály- és etnikai háttérrel rendelkező csoportok jelenítik meg, melyek eltérő esztétikai elveket képviseltek, továbbá a jazz és zene legitim definícióját is eltérő referenciák alapján alkották meg (Havas, 2017a).

${ }^{180}$ A mező autonómiafokának növekedésével párhuzamos folyamat a mezők differenciálódása, melyet az egymással legitimációs konfliktusban álló pozíciók közti relációkban ragadhatunk meg (Bourdieu, 1993). 
Az '50-es évektől kezdve azonban a muzsikus cigányok leszármazottai egyre nagyobb arányban képviselték magukat a mainstream jazzt játszók között (Retkes, 2014). E generációs váltásban tetten érhető a kávéházi cigányzene jelképezte „szórakoztató”, „kiszolgáló” paradigmából való elmozdulás a magas kulturális gyakorlatokkal asszociált jazz felé (Peterson, 1967), ${ }^{181}$ ahol a fö referenciák a jazz modernista fordulatához, tehát a '40-es évek utáni amerikai bebop-hoz kötődnek, szemben a „szvinges tánczenével” (Havas, 2017a). E generációs és „műfaji” váltás, egyúttal a „fiúk” generációjának társadalmi mezőben való legitimációját, ha úgy tetszik ,integrációját” vagy „,beágyazottságát” is növeli. A kulturális legitimitások hierarchiájában történő felfelé mobilitásnak a „cigányzenészhabitussal" összefüggésben két fontos következménye van, melyeket az empirikus részekben kísérlek meg árnyalni, illetve alátámasztani.

A jazz képviselte „művészi zene” felé történő elmozdulásnak fontos, identitást meghatározó szerepe van. Ennek következtében tovább nyílik az olló, növelve a cigányság csoportjai közti státuszkülönbségeket a „magyarcigány” jazz-zenészek javára, akik egyfajta elitcsoportot képviselnek a dominált csoporton belül. Mindezt reprezentálja a városi életvitelük és a kultúra felszentelt tereihez köthető, magas legitimitással bíró intézményekben való megjelenésük (pl. Zeneakadémia, MÜPA, MOM Kulturális Központ). Másrészt a jazz olyan terep számukra - szemben a hagyományos, többnyire a többségi társadalom közép- és felső rétegeiből rekrutálódó ügyvédi vagy orvosi pályákkal (Gáti, 2010) - ahol a zenéből élés generációs tradíciója biztosította zenei kompetenciák átörökítéséből adódó szimbolikus nyereségnek köszönhetően a többségi társadalom tagjai fölé tudnak kerekedni. Az „asszimilációs rezsim” (Kovai, 2017) felfogásával szemben, ahol mindig a nem cigány „magyar” a követendő példa és viszonyítási pont, a jazz éppen azért válik izgalmas kutatási területté, mert olyan közeget jelent, ahol a (mainstream) jazz-zenész magyarcigányok foglalják el az arisztokrácia pozícióját és elitcsoportot alkotnak. Az elméleti fejezetben bemutatott zeneihabitus-koncepció (Rimmer, 2012) az egyes müfajokon belüli hierarchizált, társadalmi jelentéssel bíró különböző distinkciókat hangsúlyozza, így magyar empirikus anyagon alkalmazva - a jazzen belüli etnicizált különbségétételek logikájának megragadásához is megfelelő fogalmi eszköznek bizonyul.

${ }^{181}$ A generációs váltás kulturális legitimitások hierarchiájában történő átpozícionálása a kulturális termelés mezőjében bekövetkező változásokkal, pl. a tradicionális kávéházi cigányzene iránti kereslet csökkenésével van összefüggésben, melyekre itt részletese nem térek ki, erről lásd pl. (Jávorszky, 1999; Retkes, 2014; Szakcsi, 2016a, 2016b). 


\section{3. Hangokba zárt folytonosság: A zenei szocializáció motívumai}

A később árnyalandó „cigány/nem cigány” különbségtétel egyik szempontja a zenei szocializációval kapcsolatos komparatív előnyök érzékelése. A belenevelődés/beletanulás distinkciót szinte az összes megkérdezett nem roma zenész említi, többségük szerint a jellemzően zenészcsaládba születő roma zenészeket „a hangszerrel kialakitott legtermészetesebb viszony jellemez", mely behozhatatlan előny egy olyan zenész számára, aki „nem nevelödik törzsi módon” (sic!) a zenébe. Az autodidakta zenész toposza is hangsúlyosabban van jelen a szocializációjukban, mint a nem roma zenészeknél. ${ }^{182}$ Ezzel összefüggésben jegyzem meg, hogy az interjúk során a Zak két komoly előnyét említik. A (1) tudástőke átadását, mely a (szakonként eltérő színvonalú) oktatásban jelenik meg, és mint (2) szocializációs közeget, ahol a fiatal zenészek kapcsolatokat építenek, ill. sokszor zenekart is alapítanak. Azon roma zenészek számára, akik családi, rokonsági kapcsolataikon keresztül kapcsolatban vannak nagy presztízsủ (roma és nem roma) zenészekkel (pl. azon prózai oknál fogva, hogy rokonsági szálak folytán együtt nőnek fel), a Tanszak mint társadalmi tőkét biztosító elitképző karizmatikus intézmény jóval kisebb fontossággal bír. A legitimitás sokkal inkább kötődik egy mainstream elit kör értékítéletéhez és „felszentelő” aktusaihoz, pl. az által, hogy kiket hívnak játszani, mint a Zeneakadémia kölcsönözte legitimitáshoz, melyet a fent említett bőgősök elismertsége is jól illusztrál.

A Montreaux-győztes Balogh Roland gitáros szólóját hallgatva a virtuóz játék technikai nehézségéről kérdeztem egy, a koncertet velem hallgató gitárost. A Balogh-ot személyesen nem ismerő jazzman tisztelet hangján reagáló válaszában azt hangsúlyozta, hogy amit ő jelenleg (27 évesen) csak gyakorol, azt a technikai tudást valószínüleg már nagyon fiatalon, tizenévesen birtokolta az épp játszó zenész. E szituáció jó példája, annak, hogy a presztízsben és legitimációban mérhető életkor és biológiai kor közti átváltások (Bourdieu, 1993) más együtthatók mentén szerveződnek, vagyis a zenészcsaládba születettek körében a zenei tőkefelhalmozás jóval korábbra esik. Ahogy egy cigány származású bőgős lényegretörően megfogalmazza a szocializációval járó számára is érzékelt elönyt:

${ }^{182}$ A magyar jazz egyik specifikuma, hogy számos elismert roma bőgős, nem túlzás azt állítani, hogy a „bőgősök krémje” (pl. Barcza Horváth József, Pecek Lakatos Krisztián, Orbán György) autodidakta módon tanult jazzt játszani. 
Édesapám olyan dolgokat tudott elmondani, amit mások a Liszten tanulnak meg. Más megtudja 25 évesen én meg megtanultam 13 évesen, érted, most ez ilyen dolog. (...) A cigányok között van a legtöbb, aki zenész, nekünk ez a kultúránk.

Míg mások a konziban vagy a Jazz Tanszéken tanulják a sztenderdeket, e zenei kompetenciák szempontjából „,privilegizált csoport” tagjai sokszor nemzetközi versenyeken érnek el helyezést ${ }^{183}$ és/vagy már aktívan pénzt keresnek a zenéből: „,mikor oda [ZAK-ra] kerültem, már nyakig benne voltam az éjszakában”. A korán megkezdett, zenészélettel együtt járó, a muzsikusok referenciacsoportjához képest legitim életstílus, az éjszakába nyúló muzsikálások, haknik, alkohol- és (esetleges) drogfogyasztás konfliktusokat szül az intézményes állami oktatással, még zeneiskolákban is, melyet már középiskolás korukban felismernek, ahogy a következő - jelenleg még nem érettségizett - 19 éves cigány származású interjúalanyom közléséből is kiderül:

Más világ vagyok a többi gyerektől, nekem ha azt mondják, hogy holnap vizsga van engem az annyira nem érdekel. Nekem az fontosabb, hogy este menjek a jam-re érted, vagy hallgassam a [Szakcsi] Robit vagy bárkit, nekem az a legfontosabb.

A muzsikuslét ethoszának „mi zenészek vagyunk, érted?!” konfliktusa a hivatalos curriculumok elvárásaival, hozzájárul a „mi” („cigányzenészek”) és a fenti idézetben szereplő „többi gyerek”, azaz „ő” megkülönböztetéséhez, ami hozzájárul(hat) a többségi társadalomtól való intézményes szankciók révén felerősített társadalmi távolság növeléséhez, miközben a zene szféráján belül az érvényesüléshez szükséges eltérő tőketípusok folytán a presztízs továbbra is biztosított maradhat. Az iskola normatív elvárásaitól és a többi (értsd: nem zenész) gyerektől való felismert távolság a strukturálisan kondicionált zenészhabitus meghatározta érvényesülési stratégiákkal van összefüggésben: már egészen fiatalon az érvényesülés tétjei a (jazz) zenei mező dimenziójában konstituálódnak. A fő motiváció arra irányul, hogy az általuk elismert nagy presztízsű (csak romákat említ a fenti interjúalanyom!) zenészek szemében elismertek legyenek, pl. a fiatalabb zenészeknél vágyként fogalmazódik meg, hogy hívják őket játszani és mikor ez

${ }^{183}$ Pecek Lakatos Krisztián pl. 13 évesen nyerte meg a Magyar Rádió jazz bőgő versenyét, ahol 30 (!) év volt a korhatár, de hasonló sikereket hosszan lehetne sorolni. 
megtörténik önigazolásnak élik meg, Grazian (2008) kifejezésével élve, az együttjáték a jazz-zenészek, ,igazi akadémiája”.

Míg a nem roma származású zenészektől a „hogyan lettél jazz-zenész?” „Hol tanultál?" kérdésekre a válaszok általában egy tipizálható narratíva körül csoportosulnak, melyben felsorolják a konzervatóriumot, majd a Jazz Tanszéket és a különbözö, eleinte nem jazzhez, de populárisabb müfajokhoz köthető zenei referenciákat, addig a roma zenészeknél a zenésznarratíva megkonstruálásának kezdete jóval az adott zenész születése elé, generációkkal korábbra esik. E narratíva társadalmilag, történetileg és kulturálisan kondicionált azonossága a kulcs az esztétikai különbségtételek etnikai dimenziójának megragadásához a magyar jazzben. Ahogy a Buendía családban a vissza-visszatérő nevek folytonossága a „magány” generációs stigmájának nyomatékosítását szolgáló művészi eszközként funkcionál (Márquez, 2017), a cigányzenészek körében a generációkon át hömpölygő visszaköszönő nevek a folytonosság kvázi-tudatos illusztrációjának felelnek meg. Az apákról, nagyapákról való elnevezés folytonosságot biztosító szimbolikus gesztusa változó körülmények és kontextusok közepette is kapcsolatot teremt a zenész felmenőkkel, mi több, a példaképek közvetítette látens elvárások kvázi-tudattalan praxisokat generálnak és termelnek újra. E cigányzenész narratíva tipikus elemei a felmenők iránti számcímekben ${ }^{184}$ is megjelenő „nosztalgikus” tisztelet, a VIII. kerület bérházainak kölcsönösségen alapuló szomszédsági viszonyai, a hétköznapokat és családi eseményeket egyaránt átitató zenei környezet magától értetődő, „,doxikus” tapasztalata (Bourdieu, 2001), az otthon intim szférájában történő rendszeres zenei happeningek, ahol olyan autoritások, mint pl. Pege Aladár (1939-2006) hétköznapi vacsoravendégekként, vagy akár mint rokonok bukkantak fel. Továbbá, egy interjúban Szakcsi Lakatos Béla (2013) által egyenesen a „cigányság központjának” titulált köreikben kultikus Mátyás tér - „a bizonyos budapesti Harlem” (!) (Csepregi, 2009) - koncentrált, „focistákból és cigányzenészekből” álló miliője, ahol a jazz műfajával és a jazz-zenészekkel való első ismerkedések is születtek a szóban forgó cigányzenész családba születő, de már jazzt játszó középgeneráció körében. ${ }^{185}$ Szakcsi így emlékezik vissza a Mátyás térre egy '81-ben, Hadas Miklós által készített interjúban:

\footnotetext{
${ }^{184}$ Pl. a „My heritage”, „For my people”, vagy „8th district” számcímekben.

185 „A jazz meg nyilván a Mátyás téren jött, futballozás közben.” válaszolja Oláh Kálmán egy interjúban (Oláh, 2002), de számos zenésztől pl. Egri Jánostól is találunk szinte szó szerinti beszámolókat. A „budapesti Harlem” szókép is jól láttatja a strukturális homológiát Magyarország „kvázi feketéi”, az 52. Utcában jazzt játszó amerikai feketék között
} 
Ez mind Mátyás tér és VIII. kerület volt, akkoriban mondták is, hogy cigány jazz-zenészek. Ma már kevesen tudják, hogy a jazz a Mátyás téren alakult ki. Pegéék, Ungár Pista és társaik a Konti utcából valók. (...) Aztán jöttünk mi, a Mátyás tér környékiek, hozzánk tartozott még Balogh Jenő zongorista, és már nőtt fel az alattunk lévő generáció: Ablakos testvérek, Jávori Vilmos, Németh János (Szakcsi, 1981).

A Lakatosok, Balogh-ok, Oláh-k, Pecek Lakatosok, Balázsok, stb. városi térben jól lehatárolt miliője volt ez a ,jazz keltető” nagyjából a '80-as évek végéig. A téren focizó - kezdetben tipikusan szülői befolyás folytán még a családi tradíciónak megfelelő hangszerrel (jellemzően hegedủvel) kezdő - akkori fiatalok zenekart alakítottak (pl. Trio Midnight), akiknek a gyerekei, az „ifjabbak”, ${ }^{186}$ együtt nőttek fel, egy generációval később már közös zenekarokban találjuk őket, - és már be is léptünk a jelenbe, ahonnan a kutatásom megkezdtem a 2010-es évek közepén. ${ }^{187}$

Ebben a miliőben a zenei tradíció tudatos átadása természetes, már az előtt elkezdődik, hogy a gyermek néhány éves korában fizikailag is képes hangszert fogni a kezébe, melynek kifejező szimbóluma Egri János nagybőgős Moods c. lemezének (1998) belső borítója (lásd 4. melléklet), ahol az 1 éves (mára énekes és jazz zongorista) kisfia, Ifj. Egri János nyúl apja basszusgitárjáért, akit nővére tart a kezében. A borítón szereplő kép meggyőzően reprezentálja család és zene összefonódását, egyben a Köztársasági Érdemkereszttel kitüntetett bőgős kávéháztól a „palotáig” vezető rögös útját is. Egri János apja - és Seress Rezsővel is együtt játszó - nagyapja (Egri János) cigányzenész nyomdokain elöször hegedüt tanuló, végül jazzbőgőre váltó Egri János kisfia (ifj. Egri János), már az elektromos basszusgitárért nyúl, mely a későmodernitásba való belépést, a technológia teremtette esztétikai kifejezőeszközökben beállt változást is szimbolizálja, hiszen a kávéházi cigányzenészek kizárólag akusztikus hangszereken, pl. hegedűvel játszottak, nem beszélve az életvitelben, öltözködésben, szakmai etikettben, a cigányzenészek és közönség megváltozott viszonyában tetten érhető számos habituális különbségről. ${ }^{188}$

\footnotetext{
${ }^{186}$ Pl. ifj. Egri János, ifj. Oláh Kálmán, ifj. Balázs Elemér stb.

187 E folytonosságot jól illusztrálja a Fonóban (2017.12.10.) megrendezett „Trio Midnight és zenész gyermekeik" címü koncert is.

${ }^{188}$ A jazz és cigányzene közti egyik legszembetűnőbb különbség az, hogy az ezredfordulóra a hungaricumnak számító tradicionális vendéglátós cigánybandák szinte teljesen megszüntek, a pesti, és más városok éjszakáiban
} 
A generációk váltakozása során identitássá vált zenéböl és zenével élés tradiciója a „mi” és „mások” distinkció lényegi aspektusa, ahogy a most 19 éves zenész, a legfiatalabb generáció tagjának közléséből is egyértelmüen látszik: „ha összeáll a család miröl beszéljenek a zenészek...? Csak a zenéröl, érted?”. Ugyanez a közlö gyermekkori traumaként említi, mikor cigányzenész édesapja - aki szinte mikortól már járni tudott vitte magával koncertekre - egy alkalommal, mikor a neves Járóka Sándor prímással volt fellépése, nem engedte a színpadon játszani, mire ő 6 évesen egy hétig nem szólt sértettségében az édesapjához, aki ilyen ,arcátlanul” megtörte a családi hagyomány szentségét apa és fia közt.

A roma zenészcsaládokban a hangszerismeret nem pusztán mint tradicionális megélhetési forma reprezentálódik, de a közösségbe tartozás kulcsmotívumaként, „malasztjaként” van jelen, melynek fontosságát a nyelv analógiájával tudnám szemléltetni. A „választékos beszéd” polgári ideáljánál fontosabb szereppel bír a zenei diszpozíciók anyanyelv szintjén történő elsajátítása, noha hasonló funkciót tölt be, mint a társadalmi különbségekre visszavezethető korai szocializáció során (tudattalanul) elsajátított, „szép beszédben”, „illendőségben” megragadható modorváltozatok (Bourdieu, 1978). A cigány származású, de - interjúalanyom kifejezésével élve - „nem cigányos”, vagyis „gádzsós” jazz-zenészt, épp a „választékos beszéddel” és „,nem roma baráti körrel” (sic!) azonosították, szemben a roma zenész által romákhoz (hozzájuk) társított, a többségi társadalom pejoratív asszociációit magán viselő, „bohém”, „bulizós”, „harsány” kategóriákkal:

Vannak a cigányoknak olyan dolgai, hogy nagyon szeretnek inni, nagyon szeretik a zenét (...). Van olyan cigány, aki gádzsós, ez a fordítottja, aki nagyon választékosan beszél, mindig, megvan a baráti köre akik nem cigányok, rá azt mondják kicsit, hogy „gádzsós”, de ez nem baj.

A zenei szocializációt „törzsi belenevelődésként” interpretáló mechanizmust a (bourdieu-i) szociológia nyelvére a zenei diszpozíciók korai elsajátításaként értelmezem. Ahogy egy magas kulturális tőkével rendelkező (szak)értelmiségi családban a magasabb szintű nyelvi kódokat sajátítja el nagyobb valószínűséggel az odaszülető gyermek, úgy nem meglepő,

való évszázados tündöklésük e fejezet írásakor már leáldozott, melynek szomorú mementója az 2017-es újévi Mága-koncert, ahol a Monti Csárdást egyes beszámolók szerint playback-ről játszották. A kávéházi cigányzenének „, a kegyelemdöfést a mulatós zene adta meg” - nyilatkozik egy zenészcsaládba született roma származású interjúalanyom. 
hogy többgenerációs - esetenként évszázadokra visszavezethető - zenei múlttal rendelkező cigányzenészek esetében a zenei szakzsargon, a hangszerekhez, zenéhez kötődő természetes, és nem intézményes ${ }^{189}$ körülmények közt tanult vagy elsajátított viszony „inkorporálódik” már kisgyermekkortól kezdve, és válik habituális elemmé. Inkorporáció alatt Bourdieu alapján a tudatalatti elsajátítási folyamatot értem (Wessely, 2005), mely által a jazzben is (de tágabb értelemben a zenében) tőkeként értelmezhető kvalitások („hallás”, hogy jó „,füle vane”, ritmusérzék, „zeneiség”, technikai tudás stb.) úgy épülnek be már a korai szocializáció során, mint másnál az anyanyelv: eröfeszités nélkül, tudat alatt.

A zenei szocializáció során elsajátított habitust a roma zenészek leginkább dogmatikus csoportja magától értetődő doxikus tapasztalatnak éli meg, sőt a fentebb hangsúlyozott folytonosságot a legkevésbé elidegeníthetetlen „genetika” vérségen alapuló antiintellektuális kategóriájával konstruálják meg, melynek hús-vér valósága nem szorul bizonyításra: „zeneiség” és cigányság ebben az egy és ugyanaz elidegeníthetetlen önazonosságát alkotja. Elsősorban nem olyasmi, amit különböző hatások folytán intézményekben megtanulnak, vagy tudós referenciák tanulmányozása során elsajátítanak (pl. a free jazzben), de a dolgok belülről fakadó, anyatejjel magukba szívott, „genetikailag kódolt" természetes rendje. Ebbe az értelmezési rendszerbe illeszkedik, hogy sokan önmagukat a feketékhez hasonlítják s az elnyomott rassz ösztön szintjén létrehozott zenei referenciáit tartják legitimnek: „,Nekem, személy szerint megerösitést jelentett, hogy képes voltam fekete zenészekkel is együtt játszani” (Ifj. Szakcsi, 2005). A genetikailag konstruált elidegeníthetetlenség jelenik meg (pl. „fekete nyelvezet”) akkor is, mikor rákérdeztem egy roma származású zenésznél, hogy miért fontos fokmérő, vagy összehasonlítási alap, hogy feketékkel játszik:

Mert ez [A jazz - H.Á.] az övék! Akármennyire európai zenei is kellet hozzá, hogy fejlődjön azért mégiscsak afroamerikai, ezt ők tudják legjobban. Bill Evans egy fúzió, az európai zenének nagyon nagy tudója, aki tudta a fekete nyelvezetet, de nem annyira, mint egy fekete.

${ }^{189}$ Ez nem jelenti azt, hogy intézményekben (konzikban) már egészen kisgyerek kortól kezdve ne tanulnának zenélni, és ne lenne komoly tanulás az eredményeik mögött. Mégis, amit e fejezetben hangsúlyozok az a családi hagyomány folytán, a szocializáció során kialakuló zenei diszpozíciók, melyeket a zeneiskolába „visznek” magukkal a zenészcsaládba született diákok. 
A (mainstream) jazz körökben legendás első generációs jazz dobosra, Pecek Lakatos Gézára való visszaemlékezés, pedig történeti perspektívából illusztrálja, a művészetből, vagyis a jazzből élő elnyomott etnikum és rassz domináns frakciói közti strukturális homológiát, és a mainstream esztétika etnikai konstrukcióját is. Ráduly Mihály (2005b) visszaemlékezésében ugyanis a mainstream esztétika (,könyörtelen szvingelés”) a „vérség” és a(z) (elnyomott) rassz kontextusában jelenik meg, ráadásul egy közös, doxikus tudásként reprezentálódik, amit nem kell „megmagyarázni”, mert egyértelmű, legalábbis a bennfentes zenészek számára:

A három említett dobos közül [Pecek] Géza volt talán a legvérmesebb, a legzsigeribb, aki könyörtelenül swingelt (lásd: Art Blakey). Kedvenc szavajárása az volt, hogy „Black man” miközben mélyen a szemedbe nézett és verte a mellét. Csak így: „Black man”, nem „I'm a black man”, hiszen mindenki értette, hogy mit mond - és úgy is dobolt. Hiszen a vér ..., a vér... - és úgy is dobolt.

A felsőbb osztályok reprodukciójához szükséges, a társadalmi mező domináns hierarchizálódási elvének megfelelő tőkefelhalmozással analóg módon, nem pusztán az elsajátított tudás maga, de tudáshoz való viszony viselkedés-modalitásokban megragadható stiláris elemei válnak a szimbolikus különbségtételek, így a hiearchizálódás alapelveivé. A mainstream jazz dogmatizmusan képviselök, akik - ahogy a következő idézetből is látszik a zenéhez való összes viszony-típus közül ,azt értékelik legtöbbre, amelyen a legkevésbé látszik az elsajátítás fáradsága" (Bourdieu, 1978: 45). Ahogy a következő, nagy presztízsü, magát „,fanatikus” roma származású zenésztől származó idézet a fentieket alátámasztja:

A másik, amiért mondják ezt a cigány jazzt, mert ez a fanatizmus...Egész nap muzsikálnak és ezt nehezen viselik el, az emberek, akik kevésbé tehetségesek: megtanulják a véres verejtékkel a megtanulhatót és jön egy tizenéves gyerek, életében nem gitározott vagy zongorázott, odaülteted a hangszerhez és eljátssza, és a cigány jazzbe semmi más nincs. Genetika, hallod, mért van az, hogy a világ legjobb klasszikus zenészei zsidók? Nagyon egyszerü, van genetikus memória, létezik, nem kérdés, ezt látom a másfél éves fiamon (...) Hogyha egy cigány elkezd zenét csinálni, addig nem nyugszik, amíg hiteles nem lesz.

Meglátásom szerint ebből a nézőpontból érthető meg leginkább koherensen az etnikai alapú - osztályozó és egyúttal osztályozott csoportként tételezett - „roma jazzistákkal” kapcsolatos különbségtételek logikája a kortárs magyar jazz leképezte kulturális distinkciók 
kontextusában. A struktúra állandóságára gondolok, nevezetesen arra, hogy a tartós, generációkon keresztül átörökített zenei diszpozíciók müfajtól relatíve független struktúrája alapvetően történeti változások és különböző erőterek (politikai, gazdasági) egymásra hatásának nyomán, az adott kulturális vagy zenei erőtér kontextusában érvényesül. Így válik a jazz Oláh Kálmán Bartók-interpretációja során a cigányzenével „,analóg müfajjá”, ${ }^{190}$ ahol nem a mủfaj maga (ami változik), hanem a müfajjal kialakított viszony elsődleges (állandó). A zenei habitus egyben életstílus-osztályokat alkotó megkülönböztető struktúra és praxisokat generáló elv, melyet a cigányzenészek a „fanatizmus” jelzővel írnak le, mely már nem zenei kategória, hanem megkülönböztető sajátosságokat magán viselő életforma is egyben.

Fanatizmus, ezt másképp nem lehet. A zenével nem foglalkozni, gyakorolni kell, hanem élni, ez egy életforma érted? (...) Minden mást köré kell építeni, család, szex, szerelem, drogok, mindent köré! (...) Csak azért van kör, mert a cigányoknál nem csinálnak mást! Csak a zene, és több a fanatikus.

A termiunusokban való tobzódást remélem oldja némileg és egyúttal illusztrálja a mondottokat az a metafora értékü megfigyelésem, mikor egy neves fővárosi ,jazz-kávézó” duókoncertjén az első 45 perces szettet a zongorista úgy játszotta le, hogy közben 2 éves (!) kisfia csendben ült a Monk-sztenderdeket éppen játszó édesapja ölében. Ehhez csak hevenyészett adalék, hogy a közönségben ülő (énekesnek készülö) 13 éves kislányának példaképe az egyik neves magyar jazz-énekesnő. A fentieket tovább szemléltetendő, álljon egy idézet Pecek Lakatos Krisztián közösségi médiában elérhető életrajzából, mely tüpontos reprezentációját adja a roma muzsikusnarratíva korábban fölvázolt központi elemeinek. ${ }^{191}$

A családjában senkiről nem tud, aki ne zenész lenne. Bőgős apukája (...) édestestvére Pecek Lakatos Géza, így ő a Magyar Köztársaság Érdemrend Lovagkeresztjével kitüntetett, 2005-ben elhunyt jazzlegenda unokaöccse. Három testvére közül a legidősebb Adorján, aki zongorista, a kisebbik bátyja László, aki bőgős és basszusgitáros, Anikó, a nővére Zongorista klasszikus zenész. A lakásban a gyakorló időkön kívül is egész nap ment a jazz, így már 3-4 évesen

190, „Ök [cigányzenészek] mindent játszanak, csak sajátos stílusban adják elö. Szóval ez majdnem ugyanaz, mint a jazz. Egyébként Bartók is azt mondta, hogy a cigányzene (...) analógiája a jazznek” (Oláh, 2002).

${ }^{191}$ Elérhető: https://www.facebook.com/krisztianpeceklakatos/posts/803854552958679 
hallgatta Miles Davis lemezeit. Apukája egy kis csellót vett neki, mert Krisztián állandóan odamászott a lefektetett bőgőjéhez, és pengetgette, sőt néha meg tudta fogni a hangokat. A kis csellóval egyre jobban ismerkedett, bőgőként kezelte, de a családi hagyományokat követve, mint mindenki, ő is a zongorával kezdte zenei tanulmányait. (...) 9-éves korában kezdett el bőgőzni. Még nem töltötte be a tízedik évét, (...) legelső fellépése Szakcsi Lakatos Bélával és Pecek Lakatos Gézával volt

\section{4. Az erős kötések ereje: rokonsági viszonyok a zenében}

Az alfejezetben az etnikum és esztétikum kapcsolatát világítom meg a családi és rokoni kötődésekkel összefüggő tartós beállítódások, vagy zenei diszpozíciók szempontjából. A rokonsági kötelékek fontosságát az is jól láttatja, hogy kutatóként belölük „készülnöm kellett”, hogy pozíciómat legitimnek, kérdéseimet pedig téttel bírónak tekintsék a válaszadók. A származásra vonatkozó ismereteim a bennfentesség kódjaiként funkcionáltak, a kutatóként tőkésített ismereteim pedig belépési adóként értelmezhetők. Egy roma származású kulcsinformátorom pl. a legnagyobb természetességgel beszél a családfakutatók kompetenciájába tartozó rokoni szálak szövevényéről (,A [Szakcsi] Béla báfelesége a Kálcsi apjának édestestvére" stb.), és addig nem kezelt közel egyenrangú beszélgető partnernek, míg kutatóként a legfontosabb rokoni szálakat meg nem tanultam, beleértve a különböző zenészek együtteseit is, akár évtizedekre visszamenőleg. Feladta a leckét s én készültem. A rokonsági viszonyok ismerete - legalábbis az informátorom személyét illetően - tehát fontos belépési adó volt: témafelvetéseimet csak ezek megtanulása után volt alkalmam komolyan megvitatni az illetővel, aki a közel egy évig folytatott, de fel nem vett beszélgetések során értékes, egészen intim személyes információkat is megosztott velem.

Mikor a „roma jazz elit” egyik tagjával alkalmam nyílt interjút készíteni jelen volt szintén 2 (roma) zenész, akik egy ideig vizsgáztatták az interjút végző kutatót. Megkérdezték például, hogy „Mozart miből jön?”, melyre szemérmesen csak annyit tudtam válaszolni: „,hát a Bach-ból”. - „No de melyikből?” - kérdezték kajánul. A kutató müveletlenségének kínos intermezzoja után kiderült, hogy a Bach család (!) a fö referencia számukra, és nem Johann Sebastian, akire egyébként naivan gondoltam. A kurzívval szedett család hangsúlyozása több alkalommal is elöjött, melynek jelentésartalmai értelmezésem szerint túlhaladják a család kizárólag vérségi kötelékként való definícióját, de ami igazán érdekes, esetenként még a pusztán etnikai kategóriát is, noha a vérségi köteléken alapuló összetartozás, ahogy az interjúrészletek is megvilágítják, fontos dimenzió. A fentebb már idézett informátortól 
származik a metafora-értékkel bíró történet két zenész közti konfliktusról, ahol a kötekedő fél „magával baszik ki” ha inzultálja az illetőt, mert „nem csak vele veszik össze, de 5 másik hangszeressel" is. ${ }^{192} \mathrm{Az}$ adott zenésszel való konfrontálódás tehát érdekellentétes: izolálódással fenyegeti az illetőt, mert az erős kötésekkel bíró közösség összezár és kirekeszt. A határok megvonását verbálisan a „testvér” szóval nyomatékosítják, akkor is, ha konkrét vérségi kapcsok csak távolról vagy egyáltalán nem kötik össze az adott zenészeket.

Nem roma nézőpontból a cigány származású jazz-zenészek egy viszonylag homogén, tradicionalista csoportként jellenek meg (Havas, 2017a), akiket „mindenki elismer, és akik viszont keveseket ismerik el.” A romák jazzban betöltött elitpozícióját egy alkalommal kontextualizálták az interjúk során szélesebb társadalmi perspektívából. Ahogy a nem roma származású interjúalanyom kifejti, a nem roma származású zenészek körében „zenei kirekesztésnek" érzékelt szimbolikus erőszak (lásd pl. Bourdieu, 2001) a többségi társadalom és a romák közti társadalmi egyenlőtlenségekre vezethető vissza. Ez egybevág azon korábbi feltételezéseimmel, mely szerint az esztétikai dogmatizmust (a mainstream jazz esztétikájához való erőteljes ragaszkodást, valamint a jazz definíciójának ez alapján történő megkonstruálását) a társadalmi erőtérben betöltött pozíció kondicionálja. Röviden, a mainstream jazz professzionális elsajátítása a romák körében státuszlegitimáló funkcióval bír:

Ennek a társadalmi csoportnak folyamatosan védekeznie kell a többségi társadalommal szemben. A romák már az előtt védekeznek, mielőtt bárki támadta volna őket - zenészberkekben is. Tehát mindenki, aki mást csinál, azt egyfajta támadásként élig meg zeneileg, ha mást csinál valaki, máshogy áll hozzá. Ennek van egy nagyon kemény hozadéka, hogy bár mindenki imádja, ahogy játszik az X vagy az Y, de hogy a közelükbe nem mennének, az biztos. (...) Kevés nem romának van kedve velük játszani, mert azt érzik, hogy csak az elutasítást meg a méregetést fogják tölük kapni. És elsősorban ez nem zenei konfliktus, ez egy társadalmi konfliktusnak a zenei manifesztálódása. (...) Nekem általában az nem szimpatikus, ha ezt valaki erőszakkal magára veszi, valamilyen frusztrációból kifolyólag, és kezd ő is úgy beszélni, mint egy jazz SS katona, ugye hogy a jazz ilyen, a jazz olyan...

Az, hogy a cigány-nemcigány különbségtételt a kortárs jazzben a fenti interjúalany intellektuális, ad hoc helyzetelemzésében elsősorban nem zenei, hanem társadalmi különbségek manifesztálódásának tartja, egyértelműen megjelenik a free és mainstream jazz

${ }^{192}$ A hangszert sem közlöm az anonimitás ez esetben is indokolt céljából. 
distinkciót tárgyaló 4. fejezetben, melyben az esztétikai dogmatizmus és társadalmi pozíció közötti kapcsolatról írtam. Az elnyomott etnikum domináns frakciójának zenei kirekesztését a nem roma származású jazz-zenészek egyfajta ellenrasszista diskurzusban interpretálják. A „jazz SS katona” vagy „bebop polizei” (sic!) kifejezések mind státuszkompenzáló és sátuszlegitimáló kizárási aktusoknak a verbális lecsapódásai azok részéről, akik e privilegizált körön kívül vannak. Azonban, ahogy a továbbiakban kifejtem, ha közelebbről szemléljük a relációkat jazz-zenészek közt, akár megnézzük az egyes együttesek összetételét és azt, hogy kivel játszanak szívesen a zenészek, a cigány-nemcigány dichotómiánál árnyaltabb képet kapunk. Ezért a fejezt során az átjárás és a befogadás kódjaira is figyelmet szentelek abból a célból, hogy érzékeltessem milyen árnyalatai, illetve strukturális variánsai léteznek e megkülönböztetésnek.

A durkheim-i értelemben „társadalmi tényként”193 funkcionáló megkülönböztetés - a roma származású jazz-zenészekhez romák és nem romák által egyaránt társított (!) homogenizáló sztereotip kategóriák - a gyakorlat során nem merev elzárkózásban nyilvánul meg, ahogy ez tapasztalható a mainstream és free jazz ellentét kapcsán, mely csoportok nem járnak egymás koncertjeire és ad hoc formációkban is csak nagyon ritkán találkoznak. Inkább az intimitás etnikailag konstruált kódjairól van szó, melynek esztétikai aspektusa a mainstream jazzhez való erős, dogmatikus ragaszkodás közös tapasztalata, melynek gyökere viszont a zenei tradíció generációs tapasztalatában keresendő. A túlnyomóan roma származású zenekarokban is találunk nem romákat és fordítva. Annak megválasztására, hogy kivel zenélnek együtt a „kiterjesztett család” analógiája szerint értelmezett „,belső kör” felé irányuló elfogultság van hatással, egyfajta pozitív diszkrimináció, aminek lényegét egy nem roma származású jazz-zenész a következőképp foglalja össze: „ők másokkal is szeretnek játszani, csak ha lehet választani inkább egymást választják”. A pusztán etnikai alapú merev szegmentálódást árnyalja azzal a roma származású zenésszel készült interjú, aki a származással, a mindent a zene köré szervező „fanatikus” életstílussal összefüggő zenei habitus esztétikai és életviteli sajátosságai alapján fogadja el zenekari társának a nem roma zenészt is. Sőt, az interjúban etnikai származástól függetlenül alkalmazza - igaz ironikus éllel - a „gádzsó” kifejezést:

${ }^{193}$ Az egyes egyénektől független objektív struktúrát (Durkheim, 1978) értek e kollektív ítéletek alatt, melyek ha nem is kényszerként hatnak a gyakorlatokra, de kondicionálják azokat és más társadalmi tényekkel magyarázhatók, mely utóbbi alatt a strukturálisan alárendelt pozícióban lévő városi magyar zenészcigányok történetileg kondicionált habituskonstrukcióinak a (zenei) szocializáció folytán történő generációkat átívelő újratermelési mintáit értem. 
[XY jazz-zenészt] azért nem mondom gádzsónak, mert az, aki képes odafigyelni 7 emberre, akkor az már nem az, hogy gádzsó, érted. A cigányok közt is nagyon sok gádzsó van és hiába zenész, nem tud kommunikálni. (...) Ha szólózni kell leszakítja a csillagos eget, de az első neki mégis az, hogy kommunikál.

A fenti interjú meglátásom szerint jól reprezentálja azt, hogy a belépési adó lényegi eleme a családi intimitás analógiájaként megjelenő odafigyelés, együttjáték és kommunikáció, valamint a zenészek közti reciprok viszonyokon alapuló szimbolikus egalitarianizmus, mely az interjúban az öncélú, virtuóz szólózással van szembeállítva. Az idézetben nem megnevezett zenész már nem „gádzsó”, aki nem tud együtt játszani, de a történetileg és etnikailag konstruált zenészhabitust elsajátító „kvázi-cigány” zenész, akit más, nem roma származású mainstream zenészek egyébként nekem személyesen is kritizáltak, koránt sem zenei alapon, de az életstílusával, ha tetszik köznapi értelemben vett habitusával összefüggésben. ${ }^{194}$

A cigány/nem cigány megkülönböztetés - bár free zenészek közül ezt néhányan nem így látják - elsősorban nem a mainstreamjazz-játék egyfajta tradicionális cigányzenében gyökerező esztétikai sajátosságokban (pl. virtuozitás) ragadható meg, hanem a mainstream jazz esztétikájának etnikai alapon történő kisajátításában, melyet a következő szituáció is jól illusztrál. Miután egy jam session alatt egy odatévedt, ismeretlen külföldi zenész beszállt játszani, a vele játszó roma származású zenész a közös improvizáció után azzal dicsérte meg a játékát, hogy ,jó cigány vagy!”. A ,jó cigány vagy” (sic!) ebben a kontextusban arra utal, hogy a cigányok tudnak igazán mainstream jazzt játszani, akkor is, ha az illető ezt a „bókot” félig ironikus megjegyzésnek szánta. A ,jó cigány” (szemben a „gádzsó jelentéstartalmaival) nem származás alapján, de habituálisan konstruálódik, mely összefügg azzal, hogy a romák és nemromák által mainstream elitnek felismert közeg (bárkit megkérdezhetünk a szcénában, ugyanazokat a neveket fogja mondani) válik követendő mintának a magyar jazzszcénában.

${ }^{194}$ A roma mainstream körökben forgó illetőről esetenként olyan kritikai megjegyzések jutottak el hozzám, hogy az illető egyrészt elzüllött, másrészt egyfajta zenén belüli parvenü túlinvesztíció folytán erőteljesen kezdett felvenni „romás” nyelvhasználatot és idomulni az új közeghez, amely befogadta őt. Ami a fejezet szempontjából releváns az, hogy a roma jazz-zenészekhez sorolt életstílus pejoratív attribútumaival (iszik, drogozik, nagyképü, arisztokratikus, túlkompenzál, ,züllött” stb.) címkézik egyesek. 
Az ide sorolt zenészek a rangok legitim elosztóiként jelennek meg, akikkel „presztízs együtt játszani”.

A megkülönböztetett különbségtételeket és a zenei habitus aspektusait megfigyelések és mélyinterjúk rekonstrukciója alapján bináris oppozíciókkal modellező kutatásom számára kifejezetten fontos volt olyan helyzetek etnográfiai leírása, melyek árnyalják a fenti képet a „romák összetartásáról”. Egy jam sessiön-ön például teljes összhangban játszott együtt az öttagú zenekar, akik közt egy neves zenész volt „csak” roma származású. Ebben semmi különös nincs, ahogy utaltam rá, a közeget nem etnikailag homogén csoportok alkotják és a mainstream jazz elsajátítása belépési adó még a legnagyobb presztízzsel bíró történetesen nem roma származású körökbe is. Azonban - figyelve a koncerten és koncert után történő interakciókat - a szóban forgó zenész a teltházas közönségből a koncert szünetében ahhoz az asztalhoz ment oda, ahol a jam-re egyébként gyakran járó roma zenészek is ültek. Nem maga a tény ragadta meg a figyelmem, hanem a bennfentesség és intimitás gesztusai, az öleléssel és „puszival” köszönés, a családias hangulat, ami az akkora etnikailag homogén asztaltársaságot körbelengte. Ez a szituáció - és száz másik, amit írhattam volna - jól illusztrálja, hogy tipikusan nem a kifelé irányuló kirekesztés manifeszt gesztusairól van szó, hanem a saját körön belül gyakorolt és közösen megélt intimitásról. Ezt a távolságtartást és határmegvonást (sarkítva: ki számít „tesónak” és ki nem) a nem roma származású zenészek egyfajta arisztokratikus távolságtartásnak érzékelnek. Nem az a jellemző ugyanis, ami csupán 2-3 alkalommal velem is előfordult az évek alatt, pl. mikor az egyik roma származású jó ismerősömmel a jazzklub előtt álltam és a kitántorgó, erősen ittas családtag zenész éreztette velem, hogy nem vagyok a kör tagja, pl. azzal, hogy álljak odébb, mert ő a „testvérével” akar beszélni, aki ezt követően szemérmes pillantásokkal tolmácsolta felém, hogy „ne vegyem magamra” a történteket, - az illető csak részeg. Egy másik ilyen példának szerencsére csak szemtanúja voltam. Ekkor a koncertet követően egy jazz-zenész barátom érdeklődve kérdezte az épp játszó zenészt, hogy miért az adott hangnemben játszotta a szám előtti bevezetőt (,,intrót”), mire a mellettünk álló jazz-zenész kollégája valósággal letámadta, ismét azt hangoztatva, hogy „ne köss bele a testvérembe”. Egy kisszekund (fél hang távolság) miatt valóságos parázsvita keletkezett.

A koncertszervezői tapasztalataim is hozzásegítettek a családi alapon konstruált „erős kötések" erejének érzékeléséhez. Az épp aktuális formáció tagjainak összeállítását az esetek többségében az adott zenészre bíztam és bízom, nem szólok bele kikkel jönnek el játszani. Mikor legutóbb felhívtam az egyik fiatal roma zenész ismerősömet, hogy van-e kedve játszani feltettem neki a kérdést: Eljönnél az XY-al zenélni? (Olyan nem roma származású 
zenészt említettem, akivel már játszottak együtt, csak akkor őt kérdeztem meg, hogy kivel játszana, aki a szóban forgó roma zenészt nevezte meg). E fordított esetben azonban visszakérdezett az illető, hogy nem jöhetne-e két közeli rokonával inkább, feltéve ha ,lehet választani”. Lehetett választani, egyúttal számomra a sokadik ilyen esetnél világosodott meg, hogy a verbálisan eszkalálódó és sztereotípiákra okot adó egy-egy, jellemzően részeg duhajkodást követő konfliktusok elfedik a lényeget, vagyis a családi alapon való összetartozás szerepét e fejezet során tárgyalt felismert különbségtételben. Meglátásom szerint, a „ha lehet választani?” felém intézett kérdésben szintetizálódnak az esztétikai preferenciák a családi összetartozással. A zenészcsaládba született roma jazz-zenészek, ahogy az előző fejezetben is utaltam rá, a közös történeti tapasztalat mellett, ha nem is mindig vérségi, de rokoni kapcsolatok hálójába ágyazódnak, melyek közt még oly távoli rokon is mint a „másodunokatestvér” az összetartozás, a „mi” konstrukciójának bináris kódját jelöli. A szerteágazó családi kapcsolathálók erős kötései nyomán már a koragyermekkori szocializáció során megismerik egymást a családok különbözö ágainak leszármazottai, a felmenők erős kötései reprodukálódnak az újabb generációban, mely hozzájárul egy zártnak érzékelt intim közeg létrejöttéhez, melyet a jazzben pl. közös zenekarok alapításában tőkésítenek. Ebben nagy szerepe van annak, hogy a zenész szülők generációja ugyanúgy elviszi koncertjeikre az ,ifjabbakat”, mint anno őket vitték cigányzenész szüleik, természetessé válik, hogy együtt kényelmesen tudnak játszani, mely meghittséget és évtizedek alatti „összeszokást” tipikusan esztétikai kategóriákkal írnak le. A fejezet címére reflektálva, a kortárs jazz kontextusában az erős kötések ereje pont a családi, rokonsági, illetve a közös történeti tapasztalatban gyökerező kölcsönös szolidaritásban nyilvánul meg. Ez által biztosítanak és szilárdítanak meg monopolpozíciókat és juttatják kölcsönös előnyökhöz e belső kör tagjait, szemben a fragmentált, gyenge kötések fontosságával, ahogy Granovetter (1973) alapmüvében a munkapiaci előnyök kapcsán rámutat. ${ }^{195}$

\footnotetext{
${ }^{195}$ Ugyan terjedelmi okok folytán sem tudom mélyebben elemezni a „gyenge kötésekkel” kapcsolatos kiterjedt diskurzust, Gans (1974) Granovetter (1973) cikkékre adott válaszában azt rója fel a szerzőnek (aki az ő adatainak újraelemzése révén írta meg a sokat citált cikkét), hogy az túlértékeli a gyenge kötések erejét, és nem vesz figyelembe kulturális, történeti és ,,mindenek fölött” politikai szempontokat melyek alapvető fontossággal bírtak a bizalom kialakulására és a munkaerőpiaci érvényesülésre a kutatott bostoni West End városrehabilitációs kontextusában. A Harvard és Columbia Egyetemek két prominensének vitáját a kérdésben továbbá lásd az AJS 1974-es második, szeptemberi számában.
} 
A szocializáció, a család kötelékei nyilvánulnak meg e választásokban, ahol a preferenciapiramis csúcsát mindig a család jelenti. A család elsőbbségét kiválóan szemlélteti az a szituáció is, mikor a jazztanszak egyik tanára a fülembe súgta, hogy „első a család”, mikor a kávézóban, ahol ültünk először - rólunk először tudomást sem véve - az ajtón belépő roma származású neves zenész először az ajtótól jóval távolabb lévő családtagjainak köszönt, és nem minket üdvözölt. Mindkettőnk meglepettségét némileg feloldandó számára a társaságomban kínosabb volt, hogy neki mint egyetemi és zenész „kollégának” nem köszöntek - az „első a család” hozzám intézett bizalmas megjegyzés, annak a felismerésnek adott hangot, hogy a számunkra akkor evidens térbeli távolsággal egyenesen arányos üdvözlési sorrend az illetőnél a társadalmi távolság logikáját követte, mely kontextusban koránt sem sértés volt a felénk irányuló látszólagos ignorancia, hanem konzekvens viselkedési minta, mely a családi kötődések logikáját követte.

A generációk során átörökített diszpozíciók, ahogy a korábbi alfejezetben próbáltam kifejteni, a zenéhez való viszonyulásban, egyfajta habituális attitüdben jelenik meg, melynek értelmezéséhez a kulcsot a magát intézményes, formális oktatással szembehelyező „antiintellektuális", genetikai, illetve vérségi alapon konstruálódó legitimációban találtam meg. E fejezet során a hangsúlyt ennek árnyalására fektettem és annak próbáltam nyomatékot adni, hogy noha a belépés nem „,beleszületéshez” kötött, a „roma mainstream” egy olyan felismert körként jelenik meg, akik jellemzően együtt játszanak, és melynek tagjai szélsőséges esetekben etnikai kategóriává formálják a mainstream jazz esztétikáját.

\section{5. A „cigány jazz” etnikai és esztétikai konstrukciói}

A következő roma származású interjúalanyom cigány/nem cigány különbségtétel lényegének a kölcsönösen osztott zenéhez való viszonyt említi, mely meglátásom szerint jó összeegyeztethető a zenei habitus fogalmával.

- H.Á.: Akkor ez egy tévhit, hogy a cigányok szeretnek együtt játszani?

- X.Y.: Nem hülyeség egyáltalán. A romák képviselnek egy stílust Magyarországon, ami nagyon nagy színvonalú stílus: Kálcsi, Robi, Béci, öreg Szakcsi, Tzumo...

- Ez azt jelenti, hogy nagyon magas színvonalon játszanak mainstream jazzt, vagy azt, hogy máshogy játsszák?

- X.Y.: Máshogy. Nagyon magasan játsszák, a legnagyobb zenészek, akiket elmondtam, de az a fontos, hogy más stílus! Általában aki roma, azok megértik egymást, ezért van az, hogy a 
Szakcsi Robi a Pecek Krisztiánnal, Orbán Gyurival, Balázs Elemérrel, és Pecek Andrissal [játszanak] és ennyiből ki van lőve, más nem jő lehet szóba, mert ők értik meg egymást. (...) A romák egyfajta stíluson belül nagyon megvannak egymással, (...) ez az igazi mainstream jazz a bebop, de kicsit hard bob is, érted... (...) Nem cigány valaki odamegy játszani, akkor lehet hogy nem tudják

- úgy összehangolni egymást.

- H.Á.: Akkor is, ha az illető tök jó hangszeres?

- X.Y.: Nem attól függ, hogy valaki jó hangszeres-e, hanem, hogy hogyan viszonyul a játékhoz.

A fenti dialógusból egyértelmüen kiderül, hogy egyrészt van alapja a jazzszcénán belüli „mainstream elit” megkülönböztetésnek, másrészt, hogy a zenei preferenciák a családi intimitás analógiája szerint müködnek. Arra a kérdésemre, hogy a cigányok mainstream jazzt játszanake magas szinten, vagy inkább arról van szó, hogy mainstream jazzt máshogy játsszák, azt a választ kaptam, hogy (verbálisan számukra is nehezen megragadható) eltérő stílust képviselnek a mainstream jazzen belül. Fontos azonban megjegyezni, hogy ez alatt a zenei habitusnak értelmezett zenéhez való hozzáállás közösségét értik, nem azt, hogy „cigányosan” („nagy amplitúdóval”, „érzelmesen”, „virtuóz módon”) játszanának mainstream jazzt, ahogy a következő roma származású interjúalanyom is nyomatékosítja:

Én nem fogok cigányosan játszani zenét, mert nem tudok. Jazzt tanultam gyerekkorom óta. Nem tudom azt az ízt játszani, én kettő -négyesen frazírozom, nem tudok csárdást kettőnégyes frazír nélkül.

A nagy presztízsű roma származású jazz-zenész interjújából egyértelmüen látszik, hogy a zenei referencia számukra a mainstream jazz, és már nem tudják játszani azt az „ízt”, ami a kávéházi cigányzenét jellemezte. Izgalmas volt megtapasztalni, hogy a romák által is felismert magas presztízsü kör néhány tagja a feléjük irányuló kritikákat (kirekesztés, arisztokratikus attitűd, lenézés, méricskélés, státuszhierarchia játékban és verbálisan történő kifejezése) esetenként egyfajta státuszukat alátámasztó bóknak tekintik, magukat - és zenei referenciáikat - emelve a jazzhierarchia csúcsára:

Család, ez a jazz, ebből indul ki a jazz, a családból. (...) bárcsak mindenki ebbe a kategóriába akarna felnőni. Ehhez fel kell nőni jazzistáknak. 
Ami megjelenik az interjúban az az, hogy a „családhoz” fel lehet - és egyfajta imperatívuszként fogalmazódik meg - fel is kell nőni. A kortárs jazz „etnikai konstrukciója” arra utal, hogy az afroamerikaikat hivatkozási alapnak tekintő, zenészcsaládba születő jazzzenészek számára „A” jazz - ami kizárólag a „sztenderd és a mainstream lehet! -, egyfajta közösségi kifejezőeszközrendszer esztétikai vonatkozása.

A fejezet végén kísérletet teszek 5 habitustípus megkülönböztetésére az interjú és megfigyelések alapján, melyek árnyalják a roma/nem roma egyébként szignifikáns különbségtételt a magyar jazzszcénában. E különböző habituskonstrukciók további kutatásokat igényelnének, mindazonáltal felhívják a figyelmet arra, hogyha közelebbről szemlélődünk, a történetileg kondicionált „cigányjazz-habitus” alvariánsait is megkülönböztetjük árnyalva egyrészt az egymásról alkotott sokszor leegyszerüsítő képet, másrészt magát a történetileg kondicionált zenei habitust. Az első típusba (1) tartozik a magát fanatikus jazz-zenésznek aposztrofáló muzsikus, aki a mainstream jazz (sztenderdek, szving, frazír) esztétikáját teszi meg az egyedüli legitim jazz-praxisnak. Ők, a „bebop polizei”, alkotják azt a tábort, akik tipikusan egy zárt - fenti interjúban is említett - körrel játszanak együtt, és magukra mint követendő példára tekintenek, akikhez fel kell nőni, melyet adott esetben elitistának és arisztokratikusnak érzékelt verbális és viselkedésbeli megnyilvánulásokkal is nyomatékosítanak. Nem ritka, hogy bár felnéznek rájuk, sokan romák közül is - „tartanak tőlük”, nem keresik a társaságukat, mert úgy érzik folyamatosan „vizsgáztatva vannak”. A (2) következő típus - egy ilyennel találkoztam - aki hagyományos roma zenészcsaládból származik, azonban magáévá teszi a romákat ért kritikákat és egyenesen kirekesztésről és rasszizmusról beszél:

Ha nem is mondják ki durván, de éreztetni akarják mindenkivel, hogy eddig és nem tovább, mert mi vagyunk a krém, a legfelsőbb polcon és mindenki csak alattunk. Ezt tartom megint csak igen szomorúnak, amikor a romák azt mondják, hogy itt Magyarországon az igazán jó jazzt, mi romák tudunk, mert csak mi tudunk frazírozni, mi ismerjük a szving lüktetést. (...) Én azt mondom hogy de jól bőgőzik az XY, aki nem roma, „hülye vagy, az a gádzsó csávó vértelen... hogy bőgőzik, az a cigánygyerek, 17 éves és kijátsza az agyát” (...) mi túl harsányak tudunk lenni, túlságosan kis sikerek után is (...) beképzeltek tudunk lenni és rasszisták tudunk lenni, nyugodtan ki lehet mondani, hogy mi romák nagyon rasszisták tudunk lenni, amikor azt mondjuk hogy gádzsók nem tudnak zenélni vértelen (...).

A harmadik típusba (3) például Szakcsi Lakatos Bélát sorolom, aki improvizáló művészként és (már!) nem jazz-zenészként aposztrofálja magát. Ugyan számára is alapvető, hogy a jazz- 
zenésznek tudnia kell szvingelni és mainstream jazzt jól játszani, azonban az improvizáció mint alapvető esztétika paradigma szétfeszíti a mainstream jazz kereteit. Jellemző, hogy klasszikus zenei darabokra játszik improvizált kadenciákat, melynek fontosságát több interjúban hangoztatja és ő az, akit a nemzetközi kritika a kelet-euróai gypsy jazz megteremtőjeként tart számon, elsősorban a $\mathrm{Na}$ Dara („Ne félj”) címü lemeze miatt. A lemezen a tradicionális (nem kávéházi!) cigányzene, a mainstream és a free jazz elemei keverednek, melyben hangsúlyos a cigányzenére jellemző rubato játékmód, melynek ritmusfelfogása analóg a jazz-szel, legalábbis tempóérzetben nem áll távol tőle. Az általa adott interjúkban megjelennek kortárs klasszikuszenei referenciák, jellemzően Eötvös Péter, Kurtág György, Ligeti György és Kocsis Zoltán, akikkel személyesen is jó viszonyt ápol. A jazz mellett az operett és balett müfajában is alkot, valamint jelenleg a Tudás fája címü operája megírásán dolgozik. A szakma úgy említi, mint a jazz megkérdőjelezhetetlen nagy öregét, aki már túl van a (mainstream) jazz honi paradigmáján: számára nem a mainstream jazz tökéletes játéka a fő tét, hanem egy különböző zenei tradíciókat szervesen integráló autentikus kelet-európai zene létrehozása. A másik ilyen zenész, aki „szétfeszíti” a mainstream jazz paradigmáját, noha ő is a jazzből jön Snétberger Ferenc, akinek játékában szintézisre lépnek latin, jazz, klasszikus és népzenei elemek. Egyik neves pályatárs pl. egy beszélgetés alkalmával feltette nekem a kérdést, hogy vajon ,jazz-zenésznek” tekinthető-e.

A negyedik (4) típusba sorolom a roma zenészcsaládba született alapvetően mainstream jazz-zenésznek kategorizált jellemzően fiatalabb generációba (huszonéves) tartozó zenészt, aki bevallása alapján mindkét, a szcénát megosztó esztétikától és körtől egyaránt távolságot és kritikai distinkciót tart. Ugyan a mainstream jazz profi tudása elengedhetetlen eleme az identitásának, azonban a kortárs klasszikus és komoly zene, valamint a kortárs modern jazz szintézise is vonzza, sokkal kritikusabban és kevésbé dogmatikusan alkotja meg a jazz definícióját mint az első, ,fanatikus” csoport tagjai, akikkel azonban szoros, tipikusan családi kapcsolatban is van. Az ötödik (5) csoportba sorolom az egyik interjúban „gádzsós” romának hívott zenészt, akit két dolog különböztet meg az első csoportba sorolt „tiszta” pólustól, akik dogmatikusan képviselik a mainstream jazzt. Egyrészt a jazz eme definíciójától való távolságtartás, a ,puha attitüd” a felé mi tekinthető jazznek. Ugyan magát ebbe a csoportba sorolja felismeri, és legitimnek tételez más alternatív jazz-zenei identitásokat és irányzatokat. A másik alapvető dolog az életstílus: a gádzsós jelző nem esztétikai szempontokat takar, de életstílusbeli különbséget, mely megjelenik a „választékos” beszédben és a szélesebb ismeretségi körben, valamint a moderáltabb „fogyasztási” szokásokban is. 


\section{6. Összefoglalás}

A fejezetben a roma származású, zenészcsaládba született jazz-zenészek zenéhez való viszonyát és esztétikai gyakorlatait vizsgáltam a zenei habitus Bourdieu nyomán alkotott (Rimmer, 2012) koncepcióval. A mélyinterjús és etnográfiai elemzésben egyúttal két felvetést, vagy hipotézist is próbáltam árnyalni, mely szorosan összefügg azzal a jelenséggel, hogy a városi zenei szórakoztatást kvázi monopolizáló kávéházi zenét, ill. magyar nótát játszó muzsikus cigányság a második világháborút követően már jazzt kezdett el játszani.

$\mathrm{Az}$ első felvetésem szerint a romák számára a mainstream jazzhez való erős ragaszkodásban megjelenő esztétikai dogmatizmus a társadalmi mezőben betöltött strukturális pozíciójukkal van összefüggésben. Röviden, számukra a mainstream jazz professzionális szinten játszása státuszlegitimáló elem, mely esztétikai szempontokon túl a fejezetekben részletezett életstílussal is összefügg. Másik felvetésem alapján - némileg árnyalva a kiszolgáltatottságot és kirekesztés különböző formáit hangsúlyozó mainstream, szociológiai és antropológiai cigánykutatásokkal kapcsolatos diskurzusokat (lásd Kovai, 2017) - a társadalmilag alárendelt etnikum domináns frakciója, a jellemzően városi zenészcigány (romungró) csoport a jazz révén nem csak kompetitív viszonyba kerül a többségi társadalommal, de a követendő legitim mintául is szolgál. A fejezet empirikus részeiben a történetileg kondicionált zenei diszpozíciók különböző dimenzióit világítottam meg, elsősorban a zenei szocializáció és család fontosságát, valamint az életstílus és esztétikai preferenciák szempontjából. Fö következtetésem szerint a mainstreamjazz-elitnek tételezett csoport esztétikai gyakorlatai, kifejezőeszközei a szocializáció során újratermelt tartós diszpozíciókkal állnak összefüggésben, mely szélsőséges esetben a vérségi és genetikai alapon konstruált zenei anti-intellektualizmusban ragadható meg, szemben pl. a free jazz-zenészek „tudós referenciák” kölcsönözte legitimitásával, mely az „autonóm müvész zenén túlmutató ethoszát” hangsúlyozza (lásd 4. fejezet). A fejezet során annak is próbáltam nyomatékot adni, hogy noha a belépés nem kizárólagosan „,beleszületéshez” kötött. A „roma mainstream” egy olyan felismert körként jelenik meg a kortárs jazzen belül, akik jellemzően együtt játszanak, és melynek tagjai szélsőséges esetekben etnikai kategóriává formálják a mainstream jazz esztétikáját (,jó cigány vagy”). A fejezet végén kísérletet tettem a zenei habitus különböző típusainak bemutatására, melyek további kutatást igényelnek, egyúttal árnyalják a fejezetben leírt zenei habitus esztétikai gyakorlatokban és életstílusban megragadható dimenzióit. 


\section{6. ÖSSZEFOGLALÁS}

Doktori értekezésemben a kortárs jazzszcéna szerkezetének és rétegződésének szociológiai elemzésére vállalkoztam, alapvetően mélyinterjús módszerrel és a bourdieu-i mezőkonstrukció modelljének alkalmazásával. A bevezető fejezetben a jazztanulmánynak fordított jazz studies (Zipernovszky és Havas, 2017) nézőpontja(i) felöl közelítettem. A fejezet során annak hangsúlyozására törekedtem, hogy a jazz tanulmányozásának interdiszciplináris nézőpontja a jazzre mint zenei, muzikológiai szempontokon jócskán túlmutató kulturális gyakorlatra tekint (Johnson, 2000, 2002b). A jellegzetesen modern, 20. századi müfaj vizsgálata során szélesebb etnikai, kultúrpolitikai, társadalmi egyenlőtlenségekkel és esztétikai kérdésekkel összefüggő kontextusok kerülnek előtérbe. Bruce Johnson kultúratudós például az ausztrál modernitást a 20. század első felében a jazz kultúr- és társadalomtörténetén keresztül próbálja megragadni a The Inaudible Music: Jazz, Gender and Australian Modernity [A hallgathatatlan zene: Jazz, dzsender és az ausztrál modernitás] címü müvében. A könyv fejezetei izgalmas elemzéseket tartalmaznak pl. a nők zenekarban betöltött szerepéről és a technológia zenei praxisokra gyakorolt hatásáról a rövid huszadik század ausztrál jazz diaszpórájában.

A 2014 őszén kezdődő kutatásom - melyhez kezdetben Ser Ádám doktorjelölt is csatlakozott - egyik határozott célja az volt, hogy az alulkutatott müfaj a szociológiai vizsgálódás legitim tárgyaként jelentjen meg a magyar tudományos életben is. Ebből kifolyólag a társadalom- és kultúratudományban történő emancipációját is célként fogalmaztam meg: a bevezetőben utaltam rá, hogy elmélyült társadalomtudományi diskurzus a müfaj társadalmi-kulturális vetületeiről csak a 2010-es évek második felétől kezd kialakulni. Noha az értékezés keretébe nem fért bele a magyar jazz első világháború utáni szociogenezisének történeti-szociológiai elemzése, a fejezetek során utaltam a mező történetének strukturális jelentőséggel bíró aspektusaira. A (1) a két világháború közti cigányzene és az Amerikából importált jazz etnicizált legitimációs konfliktusára, ${ }^{196}$ (2) a generációs váltásra, mely során az újabb zenészgenerációk, már jazzt játszanak és nem városi cigányzenét, (3) a müfaj'50-es évek hivatalos kultúrpolitikájának tiltását követő egyre növekvő kultúrpolitikai emancipációra, (4) a különböző társadalmi hátterü free- és mainstreamjazz-táborok közti ellentét intézményesülésére a '70-es évektől (Havadi, 2017),

\footnotetext{
${ }^{196}$ A témáról bővebben lásd Zipernovszky (2017), Havas (2017), Schneider (2006), Born (2010), valamint jelen disszertáció 5. fejezetének vonatkozó részét.
} 
valamint (5) a rendszerváltást követő legitimációs ,,vákuumhelyzetre”, mely a jazz populáris és klasszikus zene közti hibrid pozíciójára utal (1.2. fejezet). A fenti témám és a mező genezise szempontjából releváns korszakolás a kortárs jazzszcéna szerkezetét tanulmányozó empirikus elemzések kontextualizálását szolgálta.

Az értekezés fő elméleti tétje pedig a magyar társadalomtudományban viszonylag marginális szerepet betöltő mezöelemzés (1.5. fejezet) emancipálása volt az által, hogy egy kvalitatív kutatás keretében szisztematikusan alkalmaztam az elméletet. A kutatásom feltáró jellegü, deskriptív elemek mellett a modellalkotás igényét is megfogalmazza: egyik fó kérdésként fogalmazódott meg a presztízs- és pozíciószerzéseket meghatározó szimbolikus különbségtételek modellezése. A 4. fejezetben a rendszert alkotó és egyúttal praxisokat strukturáló free/mainstream jazz elletétet mélyinterjúkból rekonstruált bináris oppozíciók alapján vizsgáltam, majd a pozíciókhoz kötött megélhetési stratégiákat is elemeztem. Egyúttal, az etnográfiai módszerekkel vizsgálódó szcénakutatások tapasztalataira, módszerére, valamint kérdésfelvetéseire támaszkodva (Kahn-Harris, 2007) a szcéna (hierarchizált) szerkezetét feltáró kérdéseket is megfogalmaztam: ki tartozik bele? Ki számít jazz-zenésznek? Hogyan definiálják a jazzt a különböző generációba tartozó és stílusokat képviselő jazz-zenészek? Látnak-e konfliktusokat a szcénában? Kik között? Miért? Van-e privilegizált csoport a jazzben? Ha igen, kik alkotják, és miért? Hogyan lehet sikert elérni? Mi definiálja a sikert? ${ }^{197}$

A második, elméleti fejezet első felében igyekeztem a kutatásom elhelyezni a különböző rivális, kultúra- és zeneszociológiai koncepciók koordinátarendszerében. A tárgyalt koncepciók a szubkultúra, szcéna és müvészeti világ voltak, melyek különböző nézőpontok szerint koncipiálják zene és társadalom viszonyát. A Birminghami Iskola egyes korszakaihoz köthető kutatások az ifjúsági (szub)kultúrákra mint ellenhegemón mozgalmakra tekintettek, melyek a kapitalizmus tömegkultúrájának kritikáját nyújtották. Az eredetileg a Chicagói Iskolához köthető szubkultúrafogalmat újmarxista és Gramscianus keretrendszerben a háború utáni Angliában kontextualizáló, főleg etnográfiai módszereket alkalmazó kutatások fontos hozadéka, hogy emancipálták a különböző munkás- és ifjúsági kultúrákat az által is, hogy a belső értékrendszerre és az exkluzivitásra felhívták a figyelmet, szakítva a „passzív közönség”, másrészt a homogénnek látott „tömegkultúra” (részben) adornói örökségével. ${ }^{198}$

\footnotetext{
${ }^{197}$ A kutatási kérdésekről lásd az 1. mellékletet.

198 Ehhez lásd még Hesmondhalgh (2006).
} 
A következő rivális koncepció a „közösség” (community) fogalmát a '90-es évektől felváltó szcénakoncepció volt, mely kezdetben egy-egy stílus körül szerveződő, származást és ideológiát tekintve fragmentált városi közösségeket helyezett a kutatások homlokterébe. Szemben a kritikai kultúrakutatással nem kapitalizmus-kritikus ellenhegemón mozgalmakként tekintettek e közösségekre, hanem a közös jelentéskonstrukció létrehozásának mechanizmusaira fókuszáltak egy-egy szcéna jellegzetességeinek megragadásának céljából az adott, jellemzően városi miliőkben (pl. Chicagói blues szcéna). Míg a kapitalizmus hegemón tömegkultúrájával kritikus szubkultúra-kutatások számára a müfajokhoz köthető stílusok jelentéstartalmai bírtak kiemelkedő fontossággal, addig a szcénakutatások a zenei diskurzusokat és a zene közösségépítő szerepét vizsgálták. A zene közösségformáló szerepe, vagyis függő változóból magyarázó változó rangjára emelése a „kultúra szociológiája” és „kultúraszociológia” különbségtételét visszhangozza (Wessely, 2003): a „zene szociológiája” szemben a „zeneszociológiával” megkülönböztetés pedig a zene (és közönség) társadalmat alakító szerepét helyezi elötérbe (Varriale, 2014). A liverpooli rock kultúráról írott úttörő munkájában például Sarah Cohen (1991) a bandák mikro-társadalmi miliőjének gazdag etnográfiai leírását adta a városi térben, mely „lokális” megközelítést azóta transzlokális és virtuális zenei közösségekre is kiterjesztették a szcéna perspektívájából vizsgálódó kutatók (lásd pl. Bennett és Peterson, 2004; Bennett, 2004).

A szcéna- és szubkultúraperspektívák ugyan elméletileg és módszertanilag megalapozott kutatási tradíciók, mégsem ezekre a referenciákra támaszkodom az elemzésem során. Egyrészt a szubkultúra feltételez egy mainstream, (tömeg)kultúrát amivel szemben határozzák meg magukat a közösség tagjai, akiket a zenén és marginális pozíciójukon túl a közös életstílus is összeköt. Másrészt a szcéna koncepciójával kapcsolatos kritika arra vonatkozott, hogy e megközelítés égisze alatti kutatások kevesebb figyelmet fordítanak az egyes szcénák szerkezetét befolyásoló társadalmi egyenlőtlenségek szerepére (Varriale, 2014). A kutatás során alkalmazott bourdieu-i mezőkonstrukció szofisztikált modellje a műfajokon belüli státusz- és esztétikai hierarchiákkal összefüggő szimbolikus különbségtelek rendszerének megragadásához ideális analitikus eszköznek bizonyult.

Becker müvészeti világ fogalmát annak (3.1. fejezet) interakcióka történő redukcionizmusa nem alkalmaztam, ugyanis vizsgálódásaim során a történetileg kondicionált osztályozó elvekkel kapcsolatos legitimációs és delegitimációs stratégiák szerkezete foglalkoztatott, kevésbé a művészeti világként koncipiált zenei erőtér intézményes viszonyai, a kapcsolathálók szerkezete vagy a támogató személyzet (supporting personnel) kooperációs gyakorlatai a koncertek és müalkotások létrehozása során. A 
mezőelméletnek ebből kifolyólag külön fejezetet szenteltem, és a mezőelemzés lényegét kulturális termelés szociológiai értelmezésének elméleti és módszertani alapjait lerakó két fó mű alapján (Bourdieu, 1993, 1996) vázoltam fel. A mezőelmélet fogalmi hálójának kibontása során ismertettem az empirikus elemzésem szempontjából alapvető fontosságú koncepciókat (autonómia, heteronómia, ortodoxia, hierarchizálódási elvek, doxa, nomosz, autonómiafok, tőkekonverziók, pozíciószerzés, belépési adó, felszentelő intézmények, strukturális homológia stb.) a mellett érvelve, hogy a mezőkonstrukció relacionális logikája jól operacionalizálható, magyarázó erővel bíró elméleti modell, melynek szisztematikus alkalmazása során megragadható a vizsgált erőtér szerkezete és a presztízs elosztásának alapelvei. A mezőelméletről szóló fejezetben és alfejezeteiben nem egy mindent átfogó elméleti (re)konstrukció megírására törekedtem, helyette a meződinamika kutatás szempontjából is alapvető fontosságú alapelveit próbáltam meg összegezni. Az alfejezetekben igyekeztem a magyar jazzszcénát is elhelyezni a termelési típusok kontextusában, és vázlatosan bemutattam, hogy a mainstream és free jazz ellentétében jelentkező évtizedekre visszanyúlú oppozíció mely szempontok szerint modellezhető a mezőelmélet fogalomkészletével, és melyek azok a sajátos történeti fejlődésből (,kondicionáltságból”) fakadó empirikus sajátosságok, melyek mentén tovább árnyalható a mezőelméletből kölcsönzött fogalomkészlet. Az 4. empirikus fejezetben bevezetett szimultán esztétikai hierarchia koncepció a mezőnek értelmezett jazzszcéna sajátos hierarchizálódási logikát próbálta megragadni bináris oppozíciók mentén, melyeket az interjúkból és (résztvevő) megfigyeléseim alapján rekonstruáltam.

Az elméleti fejezet következő részében bemutattam néhány, a kultúraszociológiában „posztbourdieu-inek” is hívott kritikát és megközelítéseket a zeneszociológia területén. Hennion (2007) és DeNora $(2000,2004)$ esztétikai tapasztalat autonómiáját és a (zenehallgató) fogyasztó aktív, jelentés-konstruáló szerepét hangsúlyozó megközelítései ehhez a Bourdieu-kritikus vonalhoz tartoztak. Számukra az izlés nem hatalmi és gazdasági hierarchizált viszonyok szimbolikus újratermelésének instrumentuma, mely perspektívából a kultúrát fogyasztó személy csupán a folyamatosan újratermelődő objektív hatalmi struktúrák passzív „hordozója”, de aktív cselekvő, aki mindennapi élete során (DeNora, 2000) számos különböző kontextusban „működik együtt” a zenével és termeli újra szimbolikus jelentéstartalmait. Néhány bekezdés erejéig a homológia-tézis kritikai (Atkinson, 2011; Peterson, 2005) recepcióját is bemutattam, azzal a céllal, hogy felhívjam a figyelmet azokra a - javarészt kvalitatív - kutatásokra, melyek egy-egy müfajon vagy stíluson belüli distinkciók szerepére fókuszálnak (pl. Atkinson, 2011; Varriale, 2015; 
Rimmer, 2012), szemben a kulturális szegmentációt nagy mintán vizsgáló kvantitatív kutatásokkal (Chan és Golthoprpe, 2007; Sági, 2010). Erre azért volt szükség, hogy a kultúrafogyasztás és réteghelyzet összefüggéseit vizsgáló kvantitatív kutatások szempontjából is érzékeltessem milyen jelentéssel bíró, társadalmi különbségekre mutathat rá egy ,jól konstruált” tárgy (müfaj, stílus, irányzat stb.) kutatása. A számomra is referenciaértékü kutatások a szociológus által osztályozott társadalmi csoportok osztályozható osztályozási gyakorlatainak vizsgálatát helyezik előtérbe, tehát kutatási tárgyukat relacionális episztemológia és nem „szubsztantivista” logika alapján konstruálják.

Ezt követően a mezőelmélet differenciálásának igényével fellépő néhány szerzőre fókuszáltam (Hesmondhalgh, Lopes), akik a mediatizált populáris zenei irányzatok „heteronóm” gyakorlatait a mezőelméletből kiindulva kísérelték meg elemezni. Hesmondhalgh cikkében rámutatott, hogy a bourdieu-i életmüben a „korlátozott termeléshez" képest kevés szó esik a populáris kulturális, és tömegkulturális gyakorlatok elemzéséről, melyeket Bourdieu jellemzően a piaci termelés és a legitimitással bíró autonóm kulturális mezők kontextusában tárgyal. Ezen kritikus irányzatok nem az elméletet relevanciáit tagadták, viszont kiterjesztették azt újonnan létrejövő müfajok elemzésére (Varriale, 2015; Hesmondhalgh, 2006). Így tett pl. Lopes is (2002), aki a jazz történeti fejlődését az intézményesedett amerikai kulturális mezőben egy sajátos almező geneziseként mutatja be, melyet a „populáris művészet autonóm almezőjének” fordítottam, mely tulajdonképpen a populáris termelés mezőjén belül egy a magas és populáris zenei referenciákat és gyakorlatokat is integráló relatív autonómiával bíró „hibrid” almezőt jelöl. A modern jazz létrejöttében a hibriditás fogalma Lopes szerint kulcsfontosságú, mely a fenti eltérő legitimációs elvekre épülő, azokat szintetizáló kulturális gyakorlatot jelöl az amerikai zene intézményes struktúrájának kontextusában. Lopes-nél is „finomhangolásról” van szó tulajdonképpen: a bourdieu-i fogalmi hálóval próbálja megragadni a hibridjazz-paradigmát mint különböző kulturális legitimitásokból táplálkozó autonóm kulturális mezőt.

Míg azonban ő a jazz kulturális termelés mezőjében betöltött pozícióját vizsgálja egy esettanulmány keretei között, addig kutatásom homlokterében már a müfajon belüli hierachizálódás kérdései álltak a magyar kontextusban, melyben a hibriditás fogalma is jelentőséggel bírt. A különböző törtneti tradíciók és esztétikákkal kapcsolatos ideológiai diskurzus elemzésére építve a mellett érveltem (5. fejezet), hogy a történeti kondicionáltságból fakadóan a magyar jazzszcéna is hibrid természetü. Ebből kifolyólag a mezőn belüli tétek és hierarchiák szempontjából nem a pénz és művészet, illetve a „magas” (legitim) és „alacsony” (profán) müvészet oppozíciója bír az esztétikai gyakorlatok 
szempontjából strukturáló erővel, hanem a társadalmilag kondicionált különböző esztétikai referenciák interpretációnak konfliktusai, és az életvitelben és érvényesülési stratégiákban is megjelenő ideológiai diskurzusok. A szimultán esztétikai hierarchia koncepcióval e különböző kulturális legitimációkra épülő, a társadalmi beágyazódás folytán eltérő zenei habitusok által strukturált viszonyrendszer megragadására tettem kísérletet.

Az elméleti fejezet végén a Bourdieu alapján Rimmer (2012) által bevezetett zenei habitus fogalmát mutattam be, amellett érvelve, hogy a fogalom alkalmazása magyarázó erővel bír(hat) a müfajon belüli distinkció alapelveinek megragadásához. Pontosabban, az észlelési, kognitív, viselkedési és értékelési sémák tudattalanul elsajátított rendszerének tételezett mentális és társadalmi sémák közt közvetítő habitus zenei olvasatával megragadható a müvészeti eszközkészletet és osztályozó, egyúttal osztályozott zenei praxisok generáló elve. A mezőnek tételezett magyar jazz színtéren belül a „cigány jazz esztétikai és etnikai konstrukciói” címet viselő 5. fejezetben alkalmazom szisztematikusan a fogalmat a zenei szocializáció és életstílus dimenzióinak elemzése során, melyek a müfaj szerkezetét és rétegződését meghatározó tényezőkre világítanak rá a cigány származású jazzzenészek nézőpontjából.

A 3. fejezetben a kutatás módszerét fejtettem ki, és részletesen tárgyaltam a kutatásom során alkalmazott mezőelmélet koncepcióinak operacionalizálását is. A fejezet elején rávilágítottam, hogy a jazz-zenész kifejezés koránt sem „egyértelmü”: a szakirodalomban a „hétköznapi zenésznek” (ordinary musician vagy „,musicos”) fordított kifejezés (Becker és Faulkner, 2009), valamint a tánczenész (Becker, 1951) terminusokat is alkalmazzák. Az elemzések során a jazz-zenész és ,jazzmuzsikus” kifejezést alkalmazom szemben a Beckerék által javasolt hétköznapi zenésszel, egyrészt azért, mert a szcénát alkotó jazzzenészek magukat is így írják le, valamint az ,államinak”, „piaci jazznek” és „híg jazznek” titulált zenei gyakorlatokat profánnak, mi több megvetendőnek tartják, akkor is, ha a megélhetés okán rászorulnak ilyen vendéglátós haknikra (pl. „lagzi-szenvedés”).

2014 ősze óta tartó kutatásomat „kvázi-etnográfiainak” jellemeztem, mert a manuálisan kódolt mélyinterjúk $(\mathrm{N}=27)$, az illusztrációs célt szolgáló kérdőíves kutatás $(\mathrm{N}=$ 37) és a „follow up” ( $\mathrm{N}=5)$ interjúk mellett a terepnaplókban rögzített önreflexív résztvevő megfigyelésből származó etnográfiai sürü leírások is meghatározó szerepet kaptak. A féligstrukturált mélyinterjúk készítése azért is bizonyult megfelelő kutatási módszernek, mert az presztízshierarchiákkal összefüggő szimbolikus különbségtételrendszer számos esztétikai, etnikai és kulturális aspektusát lehetett ez által megragadni, pl. a nyitott kérdésekkel és a korábbi interjútapasztalatok beépítésével. Ebből a szempontból a kutatásom a megalapozott 
elmélet (Glaser, 1992) logikáját követte: a kutatási kérdéseimbe folyamatosan beépítettem a korábbi interjúk és megfigyelések tapasztalatait, valamint a kutatás során tudatosan kondicionáltam magam új irányok, magyarázó sémák és különböző nézőpontok elsajátítására. Összességben tehát a módszer és empíria dialektikus viszonya formálta a kutatási kérdéseimet, nem egy előre meghatározott interjúvázlathoz való merev ragaszkodás, mely inkább orientálta és strukturálta a kérdéseimet. Igyekeztem továbbá önreflexíven kezelni saját kutatói pozíciómat a szcénában. Ebből a szempontból kutatásomat egy „tőkefelhalmozási” folyamatnak írtam le, a kezdeti marginális kérdezőből a (kb. 250 fős) szcéna által felismert személy lettem, aki az utóbbi években koncerteket is szervezett pl. Hadik és Magvető Kávéházakban. A „kapuőri”, szervezői pozíciómat a kutatás kimenetele szempontjából alapvetően pozitívnak értékeltem: megadatott a rálátás olyan szempontokra is, melyet külsős ,,irodatudósként” egész biztosan nem ('igy) érzékeltem volna az etnográfiai szemlélet és tereppel való folyamatos viszony (koncertekre járás) ellenére sem. A zenészek vendéglátós haknikhoz való viszonyai, a különböző formációk belső dinamizmusa, a zenei partnerválasztás, a fellépésért való konkurenciaharcok, az árképzés mechanizmusai tipikusan ilyen szempontok voltak, melyeket szervezőként közelebbről is elemezhettem. A kutatásomban a társadalmi nemek szempontja csak marginálisan van jelen, részben azért mert a kulcsfontosságú hangszeres ágensek mind férfiak, másrészt mert nem volt kellő idő a jazzszcéna férfiuralmi logikájának szociológiai feltárására. A társadalmi nemekkel kapcsolatos reflexióimat a „Jazz és dzsender” címü (3.5.) alfejezetben közlöm.

A kutatásom egyik legfontosabb, leginkább téttel bíró részének „A mezöelmélet alkalmazása a vizsgált összefüggések magyarázatában címü fejezetet tekintem (3.3.fejezet), melyben példákkal illusztrálva, részletesen is kifejtettem milyen megfontolások alapján operacioanalizáltam a mezőelmélet releváns fogalmait a kvalitatív kutatás kontextusában. A mezőt alkotó osztályozott zenészeket Bourdieu nyomán olyan osztályozó ágenseknek tekintettem, akiknek az osztályozási gyakorlatait célszerü osztályozni a mezőt alkotó relációk és szimbolikus distinkciók szerkezetének megragadása során. Az osztályozott csoportok egyúttal egymást is osztályozzák különböző esztétikai és stiláris szempontok alapján, ezért a módszerani kihívást az osztályozási gyakorlatok modellezése jelenti, valamint annak elkerülése, hogy a mező hierarchikus viszonyait egy adott nézőpontból konstruálja meg a kutató. Az elemzés során épp ezért a különböző legitimációs alapon nyugvó jazz-definíciók univerzumát próbáltam rekonstruálni. Szem előtt tartva Bourdieu megfigyelését, hogy a művészeti mezőkben a legitim definíciók elsajátításáért is harcok zajlanak, engem az érdekelt, hogy milyen referenciákkal legitimálják magukat különböző 
pozíciójú jazz-zenészek, mely szorosan összefüggött azzal, hogy az egyes pozíciók kiket tekintenek legitim zenésznek, és kiket nem, tehát alapvetően a presztízs- és pozíciószerzések relacionális logikáját lehetett ez által megragadni. A másik ilyen kulcsszempont a tradícióhoz - és ezúttal a különböző profetikus alakok és referenciák kölcsönözte legitimitáshoz - való viszony diszkurzív konstrukciónak vizsgálata volt. A Charlie Parker személyéhez kapcsolódó interpretációk univerzuma jó indikátora volt a free és mainstream jazz különbségtétellel összefüggő legitimációs konfliktusoknak, melyet a 4. fejezet során elemeztem.

A Különbségtételek rendszere a mainstream - free jazz distinkcióban címet viselö 4. fejezetben az alapoppozíciónak értelmezett free/mainstream különbségtétel társadalmilag kondicionált strukturáló szerepét és aspektusait (1. táblázat) elemeztem. Ebben a fejezetben vezettem be és próbáltam meg alkalmazni a mezőelmélet differenciálásának ambíciójával fellépő szimultán esztétikai hierarchia koncepcióját. Az interjúkból és résztvevő megfigyelésekből rekonstruált bináris oppozíciók mentén e nagyjából a '70-es évektől fennálló különbségtétel vagy distinkció logikáját próbáltam megragadni több lépésben. Először a zenei tradíciók eloszlását vizsgáltam és arra a következtetésre jutottam, hogy a magukat mainstream zenészeknek mondó „tábor” a magyar referenciák közül a roma származású mainstream jazz elitet említi (Ablakos Lakatos Dezsőt, Szakcsi Lakatos Bélát, Pecek Gézát stb.). A nemzetközi referenciákból pedig az (afro)ameriaki mainstream kánon nagyjait; Miles Davist, Thelonious Monkot, John Coltrane-t, Dizzy Gillespie-t stb. A 1520 föt számláló free közeg tagjai pedig kivétel nélkül a magyar szabadzene és free jazz profetikus alakját, Szabados Györgyöt tekinti fő referenciának. Megfigyeltem továbbá, hogy a közös nemzetközi referenciákból a magukat freejazz-zenésznek mondók tipikusan a kanonikus zenészek free korszakait, valamint a kortárs klasszikus, európai free jazz és avantgárd irányzatokat is említenek hatásként, továbbá zenesztétikai művekre is hivatkoznak ideológiai alapon konstruált esztétikai alapállásuk történeti és kortárs legitimációinak felsorolásakor.

A következő lépés a fejezet során az volt, mikor a tradícióhoz való viszony diszkurzív konstrukcióit és interpretációs stratégiáit vizsgáltam: nem elégedtem meg ugyanis a referenciák ,statisztikai” megoszlásának megfigyelésével, az érdekelt, milyen esztétikaiideológiai referenciák mentén interpretálják a „kánon” meghatározó alakjait, pl. Charlie Parkert. A Parker-interpretációk kiváló indikátorai voltak a mainstream/free jazz oppozíció esztétikai szempontjainak. A mainstream zenészek Parkerben a „nomosz megteremtőjét”, a törvényalkotó mủvészt látják, aki lefektette a mainstream esztétika nyelvét, a bebop-ot. $\mathrm{E}$ 
diskurzusban Parker kapcsán a jazz mint a tánczenével (lásd Becker, 1951) szemben pozícionált magas presztízsű zenei müfaj jelenik meg. Fontos szempontként jelent meg, hogy a mainstream zenészek, és kifejezetten a mainstream szcéna krémjét alkotó cigány származású muzsikusok a magas szinten kodifikált belépési adót a mainstream esztétika (szving, sztenderdjáték, frazír) alapján konstruálják meg: az számít legitim zenésznek, és azokkal is játszanak (szívesen) együtt, akik „tudják” és „tisztelik” a mainstream nyelv alapját, a bebop-ot. A free zenészek viszont Parkerben az idejétmúlt, avítt, szórakoztatásra szánt szvinges (tánc)zene reformerét és kora (zene)esztétikai hierarchiájának avantgárd felforgatóját látják. Számukra is fontos a „nyelv”, de a mainstream zenészekkel szemben nem abszolutizálják azt, a mainstream esztétika sajátosságaira (frazeálásra, sztenderdek ismeretére, szvinges lüktetésre, bebopra, harmóniák ismeretére stb.) eszközként tekintenek. Összességében, míg a free zenészek Parkerben a tradíció ellen való lázadás tradícióját látják, a mainstream zenészek pedig az általa „törvényként” lefektetett doxát abszolutizálják és emelik a legitim jazz-zenei megnyilvánulás piedesztáljára. A fentieket összegezve, a mainstream és free jazz különbségtétel megragadható a progresszív-tradicionalista, múltközpontú-jelenidejü, ideologikus-esztétikai és újító-ortodox ellentétpárok révén.

A fejezetben kísérletet tettem a free szcéna belső dinamizmusának megragadására is azzal a céllal, hogy árnyaljam a kívülről homogénnek, „provokatívnak” és „zeneileg képzetlennek" tekintett közeget. A fö belső törésvonalak Szabados személye és saját dogmatizmusokkal és szektariánus zártságukkal kapcsolatban jelentek meg. Az ide sorolt zenészek egyrészt problematikusnak tekintik azt, hogy a mainstream és free táborok közt szinte nincsen átjárás, másrészt a szabadosi doxát dogmatikusan képviselő zenei habitusokat illették kritikával. A free szcéna belső rétegződésének külön vizsgálata a free és mainstream csoportok közti ,állóháború” hadállásai mögé tekintett, és rávilágított, hogy amit kívülről homogén csoportnak tekintenek, tulajdonképpen saját legitimációinak (esztétikai) kérdéseivel küzd. Nem free zenészek közül pedig fő kritikaként jelent meg az, hogy a free közeg kisajátítja a legitim szabad zene és free jazz definícióját: az számít free jazz zenének, és szabad zenének, akit ez a kör elismer. A free és mainstream táborok hasonló logika alapján törekszenek a legitimnek tételezett zenei praxis el- és kisajátítására. Aki jazzt játszik Magyarországon, annak az eltérő esztétikai alapokon konstituálódó hierarchizálódási elvek koordinátarendszerében kell érvényesülnie. A fejezetet vállaltan oppozíciós logika alapján alkottam meg, ugyanakkor megpróbáltam egyértelművé tenni, hogy a free és mainstream különbségtételben megragadható mezőt strukturáló alapvető bináris oppozíciók a pozícióés presztízsszerzések strukturáló elveiként funkcionálnak és számos aleset és alvariáns 
létezhet attól függően milyen intenzitással képviselik a doxát az egyes zenészek. A csoportok közti átjárások a szerint alakulnak, hogy az adott zenész - jellemzően ugyanazt a néhány, kb. 2-3 embert említik - mennyire sajátította el az adott zenéhez szükséges képességeket: Dresch Mihályt pl. jellemzően elfogadják mainstream körök azért, mert tud mainstream jazzt játszani.

A fejezet végén a megélhetési stratégiák tipizálására is kísérletet tettem. Umney és Kretsos $(2013,2015)$ londoni jazz-zenészeket kreatív munkavállalónak tekintő munkáihoz képest a fejezetben a megélhetési stratégiákat igyekeztem a mezőben betöltött pozíció(k)hoz is kötni. A különböző pénzkeresési módokhoz társított asszociációk meghatározó szerepet töltenek be a presztízsszerzésben. A profán, piaci tevékenységekkel szemben táplált ellenszenvet kellően érzékelteti a mainstream zenész példája, aki nem jazz-zenei keresőtevékenységét olyannyira titkolja a közösség előtt, hogy az interjú után megkér rá, hogy a popzenei feldolgozásokat tartalmazó oktatóvideóiról ne beszéljek másoknak, mert nem akarja, hogy „kinézzék”. A legitimitáshierarchia (1. ábra) csúcsán a saját zenei projektből való megélés áll. Ez azonban csak nagyon kevés zenésznek adatik meg, olyan mindenki által elismert művészek is, mint Oláh Kálmán, ifj. Szakcsi Lakatos Béla, Barcza Horváth József vagy Balázs Elemér is jellemzően tanítanak zeneiskolában, valamint magánórákat is adnak. A tevékenységhierarchia alján pedig a vendéglátózás, „lagzizás” és „hajón zenélés” van. A két pólus között jellemzően a változó színvonalú haknizás (vendéglátózás), session-zenélés, hangszerelés, NKA-pályázatok révén turnézás és/vagy lemezfelvétel és oktatás szerepel tipikus tevékenységként.

Arra is lehetőség kínálkozott, hogy az autonómia és heteronómia alapelveinek érvényesülését vizsgáljam a free és mainstream táborok között. A mezőelmélet olvasatában a domináns hierarchizálódási elvet megtestesítő Zeneakadémia által felszentelt mainstream jazz volna, míg az autoritásuk aláásására törekvő freejazz-zenészek eretnek csoportját tekinthetnénk a feltörekvő avantgárdnak, melyet a tiszta termelés jellemez, vagyis csak annak termelnek, akik maguk is termelök. A mainstream- és freejazz-zenészekben közös, hogy a heteronóm gyakorlatokat, a „híg”, illetve „piaci” jazzt egyértelműen elutasítják. Ha egy mainstream kategóriába sorolt zenész ilyen haknikon részt is vesz a megélhetés céljából jellemzően az interjúk során kifejti, hogy mennyire nem szeret így játszani, csak a megélhetéséhez szükséges, amit „ki kell bírni”. A két tábor közti különbség abban jelentkezik, hogy a mainstream zenészek a szakma részeként inkább elfogadhatónak tartják a piaci alapú, jellemzően vendéglátós fellépéseket, míg a freejazz-zenészek számára identifikációs, illetve habituális elem az „autonóm müvészekhez” nem illő heteronóm 
gyakorlatok kollektív elítélése. Az autonóm müvész antikommerciális ethoszából erényt kovácsolnak: többen közülük büszkén mondják, hogy „egy kézen meg tudják számolni azokat a helyzetetek", mikor olyan zenét játszottak, amit egyébként elítéltek. A free pólus piacelleneségét mindazonáltal nem tekintem a szimultán hierarchia koncepció cáfolatának, mert a felismert, téttel bíró különbségtétel alapját az eltérő kulturális legitimációkból merítő (mainstream jazz, free jazz, európai free jazz, avantgárd zene, kortárs komolyzene, kortárs szabad improvizáció, Bartók, népzene) hierarchizálódási elvek jelentik.

A doktori értekezés utolsó, 5. fejezetében a zeneihabitus-koncepció alkalmazásával a cigány származású jazz-zenészek diszpozícióit vizsgáltam, különös tekintettel a zenei szocializációra, valamint etnikum (roma származás) és esztétika kapcsolatára. A zenészcsaládba született roma származású jazz-zenészek tartós diszpozícióinak (habitusának) kialakulásában és újratermelésében meghatározó szereppel bír az a generációs váltás, mely során a kávéházi (cigány)zenét játszó városi muzsikus cigányság leszármazottai már a magaskulturális asszociációkkal bíró (mainstream) jazzt kezdtek el játszani életvitel szinten. Két, az empirikus elemzés során árnyalt hipotézist fogalmaztam meg. Az első feltevésem szerint, a mainstream jazzhez való dogmatikus ragaszkodás („esztétikai dogmatizmus") a romák részéről a státuszlegitimációval van összefüggésben: a strukturálisan alárendelt „szignifikáns másik” szerepét betöltő amerikai feketék pozíciójával strukturálisan homológ etnikum domináns frakciója (zenészcigányok) számára az esztétikai dogmatizmus a társadalmi mezöben betöltött pozíció következménye. A másik, ezzel összefüggő felvetésem szerint a romák számára a jazz olyan „terepet” jelent, ahol nem csak kompetitív viszonyba kerülnek a többségi társadalom tagjaival, de (ellentétben a középosztály által űzött „,polgári” foglalkozással) szimbolikus győzelmeik révén föléjük is tudnak kerekedni. Vagyis a jazz szférájában a mainstream jazz professzionális elsajátítása által elitcsoportként jelennek meg a többségi társadalomból származó többi jazz-zenész számára is. Ez a felvetés egybevág Rimmer (2012) azon észrevételével, hogy egy zenei erötéren belüli hierarchia és különbségtételrendszer különbözik a szélesebb társadalmi legitimitáshierarchiáktól, melyet úgy fogalmaztam meg, hogy a mező „prizmája” megtöri és sajátosan leképezi a társadalom strukturális rendjét.

A zenei habitus kifejtése során először a zenei szocializáció motívumait elemeztem és megvilágítottam, hogy már egészen kisgyermekkortól megkülönböztetett jelentősége van a zenei kompetenciák átadásának, mely alatt elsősorban nem egy stílus, vagy műfaj elsajátítását értek, de egyfajta beállitódást, hozzáállást vagy viszonyt, melyet az erőfeszítés nélküli, nem intézményesen, de a család intim miliőjében elsajátított tudáskészlet 
természetessége jellemez. Az elsősorban zeneiskolában tanult zenészekhez képest a generációk közt átörökített zenei kompetenciák (pl. hallás, zenei szakzsargon) elsajátítása a szcénában felismert komparatív előnyt jelent. A generációkon keresztül hordozott, nem megkérdőjelezett közös tudás doxikus tapasztalataként van jelen a cigányzenészek között, a „mi” és az „ők” jelentéssel bíró kódjaként funkcionál. A zenei habitus egyúttal életvitelben is megjelenik, melyben a zenéből élés korai tapasztalata is alapvető fontosságú. A „,mi” és „ők” distinkció részét képezi, ami megjelenik az iskolai rend többségi társadalmi normája és a zenészélettel együtt járó, a „családban” és a referenciaként tekintett zenei közegben legitim életstílus közötti felismert különbségekben és konfliktusokban.

Az elemzés egyik fontos következtetése volt, hogy a zenei praxisok és müvészi kifejezőeszközök megválasztását kondicionáló szocializáció során elsajátított zenei habitus legitimációja vérségi és „genetikai” alapokon konstruálódik, szemben a free közeg intellektualizáló, tanulható (!) „tudós” referenciáival. A mainstreamjazz-esztétikájának leírása során a cigány származású zenészek közléseiben a magától értetődő zeneiség, az „izzadság nélkül” megszerzett tudás, illetve a „genetikus memória” anti-intellektuális kategóriái jelennek meg. A „cigány jazz” etnikai konstrukciója a fanatikusan képviselt professzionális mainstream jazz elsajátítási aktusaiban jelenik meg, például mikor elismerése jelélül egy roma zenész „, a jó cigány vagy!” kifejezéssel dicséri meg (!) a jam session-ön beszálló külföldi zenészt. Ugyanakkor arra is rámutattam, hogy a zenei habitus és a professzionális mainstream jazz elsajátítása belépési adó lehet köreikbe, melyet az etnikailag „vegyes” zenekarokban ragadhatunk meg empirikusan. A zenészcsaládba született roma származású jazz-zenészek valójában mintaként jelennek meg a csoportok számára, melyet úgy értelmeztem, hogy az alárendelt etnikum domináns frakciója a jazzzenei mezőben elitcsoportként van jelen. A szocializáció során tudattalanul, a nyelvvel analóg módon sajátítják el, és egyúttal termelik újra zenei kompetenciákat e „privilegizált” csoport tagjai, mely pozíció biztosításában a családi kapcsolatok erős kötései biztosította reciprok kölcsönösség fontos elemként van jelen. A fejezetet végén, a mainstream/free jazz alapvető oppozíció kontextusában értelmezett zenei habitus 5 típusát különböztettem meg, és kutatási iránynak jelöltem ki a zeneihabitus-konstrukciók további vizsgálatát.

$\mathrm{Az}$ értekezést abban a reményben írtam, hogy a kortárs magyar jazzszcéna kultúraszociológiai elemzése által szélesebb kulturális distinkciókat is sikerül megragadnom. Végezetül, abban bízom, hogy a mezőelmélet alkalmazása a vizsgált összefüggések magyarázatában a Bourdieu szociológiájából kiinduló (mező)elemzés honi legitimációját is erősítheti. 


\section{Irodalomjegyzék}

Adorno, Theodor W. (1979): Fétiskarakter a zenében és a zenei hallás regressziója. In Zene, Filozófia, Társadalom. Budapest: Gondolat, 227-274.

Adorno, Theodor W. (1998): A zenével kapcsolatos magatartás típusai. In A müvészet és a müvészetek. Láng Rózsa (szerk.). Budapest: Helikon, 306-322.

Alexander, Jeffrey és Smith, Philip (2002). The Strong Programme in Cultural Theory: Elements of a Structural Hermeneutics. In Handbook of Sociological Theory. Jonathan H. Turner (szerk.). NY: Springer, 135-150. DOI: 10.1007/0-387-36274-6

Anderson, Tammy L. (2009): Rave Culture: The Alteration and Decline of a Philadelphia Music Scene. Philadelphia (PA): Temple University Press DOI: $/ 10.1177 / 1536504214558217$.

Atkinson, Will (2011): The Context and Genesis of Musical Tastes: Omnivorousness Debunked, Bourdieu buttressed. Poetics 39 (3): 169-186. DOI: 10.1016/j.poetic.2011.03.002

Atkinson, Will (2012): Where Now for Bourdieu-Inspired Sociology? Cultural Sociology 46(1): 167-173. DOI: 10.1177/0038038511416157

Babbie, Earl (1999): A társadalomtudományi kutatás gyakorlata. Budapest: Balassi Kiadó

Banks, Mark (2007): The Politics of Cultural Work. Basingstoke: Palgrave Macmillan. DOI: $10.1080 / 09548960903065428$

Barna Emília (2017): A Translocal Music Room of One's Own: Female Musicians within the Budapest Lo-Fi Music Scene. In Made in Hungary: Studies in Popular Music. Barna Emília és Tófalvy Tamás (szerk.). New York: Routledge, 47-59.

Barna Emília és Tófalvy Tamás (szerk.). (2017): Made in Hungary: Studies in Popular Music. New York: Routledge.

Bauman, Zygmunt (2000): Liquid Modernity. Cambridge: Polity

Becker, Howard S. (1949): The Professional Dance Musician in Chicago (kiadatlan M.A. tézis). Department of Sociology, University of Chicago

Becker, Howard S. (1951): The Professional Dance Musician and His Audience. American Journal of Sociology 57(2): 136-144. DOI: 10.1086/220913

Becker, Howard S. (1966): Outsiders: Studies in the Sociology of Deviance. New York: The Free Press.

Becker, Howard S. (1974): Art As Collective Action. American Sociological Review 39(6): $767-776$. 
Becker, Howard S. (1982): Art Worlds. Oakland: University of California Press.

Becker, Howard S. (2000): The Etiquette of Improvisation. Mind, Culture and Activity 7(3): 171-176. DOI:10.1207/S15327884MCA0703_03

Becker, Howard S. és Robert R. Faulkner (2009): „Do you know...?” The Jazz Repertoire in Action. Chicago: University of Chicago Press.

Bennett, Andy (1999): Subcultures or Neo-Tribes? Rethinking the Relationship between Youth, Style and Musical Taste. Sociology 33(3): 599 - 617. (Magyarul: Szubkultúrák vagy neo-törzsek? A fiatalok, a stílus és a zenei ízlés közötti kapcsolat újragondolása. Replika (53): 127-143. Interneten: http://replika.hu/system/files/archivum/replika\% 2053-08.pdf.) DOI: 10.1177/S0038038599000371

Bennett, Andy (2000): Popular Music and Youth Culture. Music, Identity and Place. London: Macmillan. DOI:10.1017/S0261143002252083

Bennett, Andy (2004): Consolidating the Music Scene Perspective. Poetics (32): 223-234. DOI:10.1016/j.poetic.2004.05.004.

Bennett, Andy és Richard A. Peterson (2004): Local, Translocal and Virtual. Nashville: Vanderbilt University Press. DOI: 10.1016/j.poetic.2004.05.004

Bennett, Andy és Paul Hodkinson szerk. (2012): Ageing and Youth Cultures. Music, Style and Identity. Oxford: Berg.

Benzecry, Claudio és Collins, Randall (2014): The High of Cultural Experience: Toward a Microsociology of Cultural Consumption. Sociological Theory 32(4): 307-326. DOI: $10.1177 / 0735275114558944$

Bevan, Mark T. (2014): A Method of Phenomenological Interviewing. Qualitative Health Research (24):1 136-144. DOI: 10.1177/1049732313519710

Bognár Bulcsu (2016a): „Nem a tagadást kell tagadni, hanem állítani kell.” Beszélgetés Szabados György életművéről, 1 rész. Replika (99): 7-17. Interneten: http://replika.hu/replika/99-01 (letöltve: 2018. május 8.)

Bognár Bulcsu (2016b): „Nem a tagadást kell tagadni, hanem állítani kell.” Beszélgetés Szabados György életművéröl, 2. rész. Replika (100): 9-20. Interneten: http://replika.hu/replika/100-01 (letöltve: 2018. május 8.)

Bognár Bulcsu (2017): „Nem a tagadást kell tagadni, hanem állítani kell.” Beszélgetés Szabados György életművéről, 3. rész. Replika (101-102): 197-209.

Born, Georgina (2010): The Social and the Aesthetic: For a Post-Bourdieuian Theory of Cultural Production. Cultural Sociology 4(2): 171-208. DOI: $10.1177 / 1749975510368471$ 
Bourdieu, Pierre (1977): Outline of a Theory of Practice. Cambridge: Cambridge University Press

Bourdieu, Pierre (1978): Az iskolai kiválóság és a francia oktatási rendszer értékei. In $A$ társadalmi egyenlötlenségek újratermelödése. Berend et al. (szerk.). Budapest: Gondolat, 71- 129.

Bourdieu, Pierre (1984 [1979]): Distinction. A Social Critique of the Judgement of Taste. London: Routledge. [Magyarul részlet: Bourdieu, Pierre (2010): A habitus és az életstílusok tere. Ford. Fáber Ágoston. Replika (72): 49-94.]

Bourdieu, Pierre (1986): The Forms of Capital. In Handbook of Theory and Research for the Sociology of Education. Richardson, John (szerk.). New York: Greenwood, 241-258. [Magyarul: Bourdieu, Pierre (1999): Gazdasági tőke, kulturális tőke, társadalmi tőke. In A társadalmi rétegződés komponensei. Angelusz Róbert (szerk.). Budapest: Új Mandátum, 156-177.]

Bourdieu, Pierre (1988): Homo Academicus. Stanford: Stanford University Press.

Bourdieu, Pierre (1990): Photography: A Middle-brow Art. Cambridge: Polity.

Bourdieu, Pierre (1991a): Langauge and Symbolic Power. Cambridge: Polity Press.

Bourdieu, Pierre (1991b [1971]): Genesis and Structure of the Religious Field. Comparative Social Research (13): 1-44.

Bourdieu, Pierre (1991c): On the Possibility of a Field of World Sociology. In Social Theory for a Changing Society. Bourdieu, Pierre és Coleman, James S. (szerk.). New York: Russell Sage Foundation, 373-387.

Bourdieu, Pierre és Wacquant, Loic (1992): An Invitation to Reflexive Sociology. Chicago: University of Chicago Press.

Bourdieu, Pierre (1993): The Field of Cultural Production. New York: Columbia University Press.

Bourdieu, Pierre (1996 [1992]): The Rules of Art: Genesis and Structure of the Literary Field. Ford. Susan Emanuel. Cambridge: Polity Press.

Bourdieu, Pierre (1998a): Alapelvek a kulturális alkotások szociológiájához. In A kultúra szociológiája. Wessely Anna (szerk.). Budapest: Osiris-Láthatatlan Kollégium, 174185 .

Bourdieu, Pierre (1998b): On Television and Journalism. London: Pluto. (magyarul Bourdieu, Pierre (2001): Előadások a televizióról. Ford. Erőss Gábor. Budapest: Osiris)

Bourdieu, Pierre (2001): Masculine Domination. Stanford University Press. 
Bourdieu, Pierre (2003): Participant Objectification. Huxley-érem átvételekor tartott előadás. Royal Anthropological Institute, London, 2000. december 6. 281-294. DOI: $10.1111 / 1467-9655.00150$

Bourdieu, Pierre és Nice, Richard (2004): Science of Science and Reflexivity. Chicago: University of Chicago Press.

Bourdieu, Pierre (2010 [1979]): A habitus és az életstílusok tere. Replika (72): 49-94.

Bourdieu, Pierre (2013): A müvészet szabályai: az irodalmi mezö genezise és struktúrája. Ford. Seregi Tamás. Budapest: Budapesti Kommunikacios és Üzleti Főiskola

Bottero, Wendy és Crossley, Nick (2011): Worlds, fields and networks: Becker, Bourdieu and the structures of social relations. Cultural Sociology 5(1): 99-119. DOI: $10.1177 / 1749975510389726$

Braggs, Rashida K. (2016): Jazz Diasporas: Race, Music, and Migration in Post-World War II Paris. Berkeley CA: University of California Press. DOI: 10.1525/ 9780520279346.003 .0007

Brown, Julie (2000): Bartók, the Gypsies, and Hybridity in Music. In Hesmondhalgh, David és Born, Georgina (szerk.): Western Music and Its Others: Difference, representation and Appropriation in Music. Berkeley: University of California Press, 119-143.

Bryson, Bethany (1996): „Anything But Heavy Metal.” Symbolic Exclusion and Musical Dislikes. American Sociological Review 61 (5): 884-899. DOI: 10.2307/2096459

Budds, Michael J. szerk. (2002): Jazz and the Germans. Essays on the Influence of ,Hot” American Idioms on 20th Century German Music. New York: Pendragon Press.

Bukodi Erzésbet (2007): Social stratification and cultural consumption in Hungary: Book readership. Poetics 35(2-3): 112-131. DOI: 10.1016/j.poetic.2007.03.001

Bukodi Erzésbet (2010): Social stratification and cultural participation in Hungary: a postcommunist pattern of consumption? In Social status and cultural consumption. Chan, Tak Wing (szerk.). Oxford: University of Oxford. DOI:10.1093/esr/jc1016

Chan, Tak Wing és Goldthorpe, John H. (2007): Social Stratification and Cultural Consumption: Music in England. European Sociological Review (23): 1-29. DOI:10.1093/esr/jc1016

Cohen, Stanley (1972): Folk Devils and Moral Panics. The Creation of the Mods and Rockers. Oxford: Martin Robertson. [Magyarul részlet: Ifjú szörnyetegek. A modok és a rockerek megteremtése. Replika (40): 49-65. Interneten: http://replika.hu/system/files/archivum/replika_40-03_cohen.pdf.] 
Cohen, Sara (1991): Rock Culture in Liverpool: Popular Music in the Making. Oxford: Clarendon Press.

Danto, Arthur (1964): The Artworld. The Journal of Philosophy 61(19): 571-584.

Davis, John S. (2012): Historical Dictionary of Jazz. Lanham: Scarecrow Press.

DeBoise Sam (2016): Post-Bourdieusian Moments and Methods in Music Sociology: Toward a Critical, Practice-Based Approach. Cultural Sociology 10(2): 178-194. DOI: $10.1177 / 1749975516628309$

De la Fuente, Eduardo (2007): The "New Sociology of Art": Putting Art back into Social Science Approaches to the Arts. Cultural Sociology 1(3): 409-425. DOI: $10.1177 / 1749975507084601$

De La Fuente, Eduardo (2010): The Artwork Made Me Do It: Introduction to the New Sociology of Art. Thesis Eleven 103(1): 3-9. DOI: 10.1177/0725513610381377

DeNora, Tia (2000): Music in Everyday Life. Cambridge: Cambridge University Press. DOI: 10.1017/CBO9780511489433

DeNora, Tia (2004): Historical Perspectives in Music Sociology. Poetics (32): 211-21. DOI:10.1016/j.poetic.2004.05.003. 212.

DeVeaux, Scott (1997): The Birth of Bebop: A Social and Musical History. Berkeley: University of California Press

DeVeaux, Scott (2017 [1991]): A jazzhagyomány konstruálása: a jazz historiográfiája. Replika (101-102): 13-40.

Dregni, Michael (2004): Django: The Life and Music of a Gypsy Legend. New York: Oxford University Press.

Durkheim, Émile (1978): A társadalmi tények magyarázatához. Budapest: Közgazdasági és jogi Könyvkiadó, 23-94.

Elias, Norbert (1978): What is Sociology? London: Hutchinson of London, 51-70.

Federmayer Éva (2017 [2011]): Millenniumi Budapest és ragtime: A faj, a nem és az osztály (rendiség) mintázatai a korai magyar jazzkorszakban. Replika (101-102): 41-65.

Finkelstein, Sidney (1948): Jazz. A People's Music. New York: Citadel.

Frith, Simon (1996): Performing Rites: On the Value of Popular Music. Oxford: Oxford University Press.

Gabbard, Krin szerk. (1995): Jazz Among the Discourses. Durham-London: Duke University Press.

Gabbard, Krin (2002): The Word jazz. In The Cambridge Companion to Jazz. Mervyn Cooke és David Horn (szerk.). Cambridge: Cambridge University Press 1-6. 
Gans, Herbert J. (1974): Gans of Granovetter's Strenght of Week Ties. American Journal of Sociology (80)2: 524-527.

Gáti Annamária (2010): Társadalmi háttér és mobilitás. In Diplomás Pályakövetés IV. Frissdiplomások 2010. Garai et al. (szerk.). Bp: Educatio Társadalmi Szolgáltató Nonprofit Kft., 177-192.

Geertz, Clifford (1976): Art as a Cultural System. Comparative Literature 91(6): 1473 1499.

Gelder, Ken és Thornton, Sarah (1997): The Subcultures Reader. London: Routledge

Glaser, Barney G. és Strauss, Anselm L. (1967): The Discovery of Grounded Theory: Strategies for Qualitative Research. Chicago, IL: Aldine Publishing Company.

Glaser, Barney G. (1992): Basics of Grounded Theory Analysis: Emergence vs Forcing. Mill Valley, California: The Sociology Press.

Gonda János (1965): Jazz-Történet, elmélet, gyakorlat. Budapest: Zenemükiadó.

Gonda János (2004): Jazzvilág. Budapest: Rózsavölgyi és Társa.

Granovetter, Mark S. (1973): The Strength of Weak Ties. American Journal of Sociology (78)6: 1360-1380.

Grazian, David (2008): The Jazzman's True Academy. Ethnography, Artistic Work and the Chicago Blues Scene. Ethnologie française, nouvelle serie 38(1): 49-57. DOI: 10.3917/ethn.081.0049.

Hadas Miklós (1992): Pegazus és Rosinante. Töredékes reflexiók Csepeli György és Wessely Anna írása kapcsán. Replika (1-2): 26-30.

Hadas Miklós (1998): Bartók, a természettudós. Replika (33-34): 21-33.

Hadas Miklós (2001): Pierre Bourdieu, egy totális szociológus. Magyar Lettre Internationale (40): 13-17.

Hadas Miklós (2002): A libido academica narcizmusa. Replika (47-48): 175-193.

Hadas Miklós (2009): A maszkulinitás társadalmi konstrukciói és reprezentációi. Nagydoktori értekezés.

Hadas Miklós szerk. (2011): Férfikutatások: TÁMOP online-szöveggyüjtemény. Interneten: http://tatk.elte.hu/file/hadas.pdf

Hadas Miklós (2015): Bourdieu esete az áramló folyóval és a parti sziklákkal: Kritikai adalékok a Férfiuralomhoz 17 év után. Buksz (27):1-2. 55-62.

Hall, Stuart és Tony Jefferson (1975): Resistance Through Rituals. Youth Subcultures in Post-War Britain. London: Routledge. 
Hanquinet, Laurie és Savage, Mike (2016): Routledge International Handbook of the Sociology of Art and Culture. NY: Routledge DOI: 10.4324/9780203740248.ch1

Havadi Gergő (2011): Doktrinerizmus, privilégiumok és szankciók a zenei életben. In Zenei

Hálózatok. Tófalvy Tamás et al. (szerk.). Budapest: L’Harmattan, 129 - 158.

Havadi Gergő (2017): A magyar jazzszubkultúra ethosza a '70-es és '80-as években: „a kulturális lázadás életstílusa”. Replika (101-102): 125-147.

Havas Ádám (2017a): A szabadság dogmatizmusa és a dogmatizmus szabadsága: különbségtételek rendszere a mainstream-free jazz dichotómiában. Replika (101-102): 169-196.

Havas Ádám (2017b): Book review: The Inaudible Music by Bruce Johnson. Foreword by Simon Frith. New South Wales: Currency Press 2000, 244. 1-6. Interneten: https://static1.squarespace.com/static/58bf64e6c534a5e3ac61401d/t/5931499c197aea 549df14f9a/1496402337710/HavasInaudibleMusicBOOKREVIEW.pdf

Havas Ádám (2018a): Book Review: Made in Hungary: Studies in Popular Music. Emília Barna és Tamás Tófalvy (szerk.). Routledge 2017. A Journal of the International Association for Hungarian Studies and Balassi Institute. 2018(02): 283-292. DOI: 10.1556/044.2017.32.1.12

Havas Ádám (2018b): A kortárs jazz esztétikai és etnikai konstrukciói: „cigány jazz” és zenei habitus. Szociológiai Szemle (megjelenés alatt)

Havas Ádám és Ser Ádám (2017): „Szegény rokonok” - A budapesti jazzszíntér konstrukciója. Replika (101-102): 147-168.

Hebdige, Dick (1979): Subculture: The Meaning of Style. London and New York: Routledge (magyarul: Hebdige, Dick (1995 [1979]): A stílus mint célzatos kommunikáció. Replika (17-18): 181-200.)

Hennion, Antoine (2007): Those Things That Hold Us Together: Taste and Sociology. Cultural Sociology 1(1): 97-114. DOI: 10.1177/1749975507073923

Hesmondhalgh, David (2005): Subcultures, Scenes or Tribes? None of the Above. Journal of Youth Studies. 8(1): 21 - 40. DOI: 10.1080/13676260500063652

Hesmondhalgh, David (2006): Bourdieu, the Media, and Cultural Production. Cultural sociology 28(2): 211-231. DOI: 10.1177/0163443706061682

Hilgers, Mathieu és Mangez, Eric (2014.): Bourdieu's theory of social fields: Concepts and Applications. London: Routledge

Hodkinson, Paul (2005): Beavatottak és kívülállók. Replika (53): 145-164.

Hoggart, Richard (1958): The Uses of Literacy. Harmondsworth: Penguin Books 
Jauss, Hans R. (1982): Toward an Aesthetic of Reception. Trans: Timothy Bahti. Minneapolis: University of Minnesota Press

Jávorszky Béla Sz. (2014): A magyar jazz története. Budapest: Kossuth

Johnson, Randal (1993): Editor's Introduction. In The Field of Cultural Production. Pierre, Bourdieu (1993). New York: Columbia University Press.

Johnson, Bruce (2000): The Inaudible Music: Jazz, Gender and Australian Modernity. Sydney: Currency Press

Johnson, Bruce (2002a): The Jazz Diaspora. In The Cambridge Companion to Jazz. Cooke, Mervyn (szerk.). NY: Cambridge University Press, 33-54.

Jonhson, Bruce (2002b): Jazz as Cultural Practice. In The Cambridge Companion to Jazz. Cooke, Mervyn (szerk.). NY: Cambridge University Press, 96-113.

Johnson, Whitney (2015): Weird Music: Tension and Reconciliation in Cultural-Economic Knowledge. Cultural Sociology (11):1 1-16. DOI: 10.1177/1749975516651287

Jorgensen, Danny L. (1989): Participant Observation: A Methodology for Human Studies. Applied Social Methods Series Vol. 15. Newbury Park CA: Sage

Kacsuk Zoltán (2005): Szubkultúrák, poszt-szubkultúrák és neo-törzsek. Replika (53): 91110.

Kacsuk Zoltán (2015): From geek to otaku culture and back again. The role of subcultural clusters in the international dissemination of anime-manga culture as seen through Hungarian producers. Graduate School of Manga, Kyoto Seika University. PhDértekezés.

Kahn-Harris, Keith (2007): Extreme Metal: Music and Culture on the Edge. Oxford: Berg. Kerekes György és Pallai Péter (2015): A jazz évszázada. Fidelio Media Kft.

King, Nigel (1994): The Qualitative Research Interview. In Qualitative methods in organizational research. Cassell, Catherine és Symon, Gillian (szerk.). London: Sage, $14-25$.

Kirschbaum, Charles (2007): Careers in the Right Beat: US Jazz Musicians: Typical and Non-Typical Trajectories. Career Development International 12(2): 187-201. DOI:10.1108/13620430710733659

Kovai Cecilia (2015): A cigány-magyar különbségtétel és a rokonság. Pécsi Tudományegyetem Kultúratudományi Doktori Program. PhD-értekezés.

Kovai Cecilia (2017): Kemény István munkáinak hatása a magyarországi szociológiai cigánykutatásokra egy antropológus nézőpontjából. Replika (104): 23-30. 
Kovalcsik Katalin (2006): A „, cigány nótától” az ,,autentikus cigányzenéig”. PhD-értekezés.

Liszt Ferenc Zenemüvészeti Egyetem

Könczei Csongor (2011): A kalotaszegi cigányzenészek társadalmi és kulturális hálózatáról.

Kriza könyvek 36.

Kucsera Csaba (2008): Megalapozott elmélet: egy módszertan fejlődéstörténete. Szociológiai Szemle 2008/3 92-108.

Ladányi János és Szelényi, Iván (2005): Van-e értelme az underclass kategória használatának? In Szociális és etnikai konfliktusok. Tanulmányok a piacgazdasági átmenet időszakából (1987-2005). Ladányi János (szerk.). Budapest: Új Mandátum Könyvkiadó, 470-476.

Ladányi János (2004): A kirekesztettség változó formái. Budapest: Napvilág.

Lamont, Miche'le (1992): Money, Morals, and Manners: The Culture of the French and the American Upper-Middle Class. Chicago: University of Chicago Press

Latour, Bruno (2005): Reassembling the Social: An Introduction to Actor-Network Theory. Oxford: Oxford University Press.

Lopes, Paul (2000): Pierre Bourdieu's Fields of Cultural Production: A Case Study of Modern Jazz. In Pierre Bourdieu: Fieldwork in Culture. Brown, Nicholas és Szeman Imre (szerk.). Oxford: Roman and Littlefield.

Lopes, Paul (2002): The Rise of a Jazz Art World. Cambridge: Cambridge University Press. Maanen, Hans (2009): How to Study Art Worlds: On the Societal Functioning of Aesthetic Values. Amsterdam: Amsterdam University Press.

Macdonald, Raymond és Graeme Wilson (2005): Musical Identities of Professional Jazz Musicians. A Focus Group Investigation. Psychology of Music 33(4): 395-417. DOI: $10.1177 / 0305735605056151$

Malecz Attila (1981): A jazz Magyarországon. Budapest: TK.

Malecz Attila (1987): Zenei ízlés Magyarországon. Budapest: TK.

Marshall, Lee (2011): The sociology of popular music, interdisciplinarity and aesthetic autonomy. The British Journal of Sociology 62(1): 154-174. DOI: 10.1111/j.14684446.2010.01353.x

Márquez, Gabriel G. (2017): Száz év magány. Budapest: Magvető

McIntyre, Morris H. (2001): How to Develop Audiences for Jazz. (Kutatási jelentés az Arts Council of England finanszírozásával létrejött kutatásról)

McKay, George (2005): Circular Breathing. The Cultural Politics of Jazz in Britain. Durham, NC: Duke University Press. 
Nicholson, Stuart (2005): Is Jazz Dead? Or Has It Moved to a New Address. New York: Routledge.

Nightingale, Virginia (2008): Chapter 6: Why Observing Matters. In Research Methods for Cultural Studies. Pickering, Michael (szerk.). Edinburgh: Edinburgh University Press. $105-125$.

Nylander, Erik (2014): Mastering the Jazz Standard: Sayings and Doings of Artistic Valuation. American Journal of Cultural Sociology 2(1): 66-96. DOI: 10.1057/ajcs.2013.13

Panofsky, Erwin (1986): Gótikus épitészet és skolasztikus gondolkodás. Budapest: Corvina Peretti, Burton W. (1993): The Jazz Studies Renaissance. American Studies 34(1): 139-149. Pernye András (1964): A jazz. Budapest: Gondolat.

Perrenoud, Marc (2007): Les musicos. Enquęte sur des musiciens ordinaires. Párizs: La Découverte

Peterson, Richard A. (1967): Market and Moralist Censors of a Rising Art Form: Jazz. Arts in Society (4): 253-64.

Peterson, Richard A. (2005): Problems in comparative research: The example of omnivorousness. Poetics (33): 257-282. DOI:10.1016/j.poetic.2005.10.002

Peterson, Richard A. és Simkus, Albert (1992): How musical tastes mark occupational status groups. In Cultivating differences: Symbolic boundaries and the making of inequality. Lamont, Michéle és M. Fournier (szerk.). Chicago: University of Chicago Press, 152 186.

Peterson Richard A. és Kern Roger M. (1996): Changing Highhbrow Taste. From Snob to Omnivore. American Sociological Review 61(5): 900-907.

Pfadenhauer, Michaela (2005): Ethnography of Scenes. Towards a Sociological Life-world Analysis of (Post-traditional) Community-building. Qualitative Social Research (6):3 23-69. DOI: $10.17169 /$ fqs-6.3.23

Pickering, Michael szerk. (2008): Research Methods for Cultural Studies. Edinburgh: Edinburgh University Press.

Pinhiero, Diogo L. és Timothy J. Dowd (2013): The Ties among the Notes. The Social Capital of Jazz Musicians in Three Metro Areas. Work and Occupations 40(4): 431464. DOI: $10.1177 / 0730888413504099$

Platt, Jennifer (1983): The development of the "participant observation" method in sociology: Origin myth and history, History of the Behavioral Sciences 19 (14): 379393. DOI: $10.1002 / 1520-6696$ 
Pozsár Máté (2016a): Jazzelmélet. Budapest: Binder Music Factory

Prior, Nick (2008): Putting a Glitch in the Field: Bourdieu, Actor Network Theory and Contemporary Music. Cultural Sociology 2(3): 301-319. DOI: $10.1177 / 1749975508095614$

Prior, Nick (2011): Critique and Renewal in the Sociology of Music: Bourdieu and Beyond. Cultural Sociology 5(1): 121-138. DOI: 10.1177/1749975510389723

Prior, Nick (2013): Bourdieu and the Sociology of Music Consumption: A Critical Assessment of Recent Developments. Sociology Compass 7(3): 181-193. DOI: $10.1111 /$ soc 4.12020

Prior, Nick et al. (2017): Editorial Statement: Tracing, Making and Locating Cultural Sociology. Cultural Sociology 11(1): 3-10. DOI: 10.1177/1749975516687486

Ráduly Mihály és Bognár Bulcsu (2016): „Nem a tagadást kell tagadni, hanem állítani kell.” Szabados György életművéről Ráduly Mihály beszélget Bognár Bulcsuval. Replika (99): 7-17.

Rechniewski, Peter (2008): The Permanent Underground. Australian Contemporary Jazz in the New Millennium. Platform Papers. Quarterly Essays on the Performing Arts (16): $1-59$.

Regev, Motti (2013): Pop-Rock: Aesthetic Cosmopolitanism and Late Modernity. Cambridge: Polity Press.

Retkes Attila (2012): A modern magyar jazz születése és fogadtatása (1962-1964). (Előadás szerkesztett változata, elhangzott 2012. november 29-én.)

Rimmer, Mark (2012): Beyond Omnivores and Univores: The Promise of a Concept of Musical Habitus. Cultural Sociology 6(3): 299-318.

Ritchie, Jane és Lewis, Jane szerk. (2003): Qualitative Research Practice: A Guide for Social Science Students and Researchers. London: Sage Publications

Ritzer, George (2010): Sociological Theory. 8th ed. McGraw-Hill: New York.

Ritzer, George és Smart, Barry (2003): Handbook of Social Theory. Sage: London

Sallaz, Jeffrey és Zavisca, Jane (2007): Bourdieu in American Sociology, 19802004. Annual Review of Sociology 33(1): 21-41.

Santoro, Marco (2008): Culture As (And After) Production. Cultural Sociology 2(1): 7-31. DOI: https://DOI.org/10.1177/1749975507086273

Santoro, Marco (2013): Putting Circuits into Fields, or How Italian Canzone Gained the Status of 'Art' in the Music Market. Eur. Soc. 15(2): 229-245. DOI: $10.1080 / 14616696.2013 .767928$ 
Savage, Mike és Silva, Elizabeth B. (2013): Field Analysis in Cultural Sociology. Cultural Sociology 7(2): 111-126. DOI: 10.1177/1749975512473992

Sági Matild (2010): Kulturális szegmentáció: „mindenevők”, „válogatósak”, ,,egysíkúak” és „nélkülözők”? Az „omnivore-univore” modell alkalmazhatósága Magyarországon. In Társadalmi Riport 2010. Kolosi Tamás és Tóth István György (szerk.). Budapest: TÁRKI: $288-311$.

Schneider, David E. (2006): Bartók, Hungary, and the Renewal of Tradition: Case Studies in the Intersection of Modernity and Nationality. Berkeley: University of California Press

Shanks, Barry (1988): Transgressing the Boundaries of a Rock 'N' Roll Community. (Konferencia-előadás, First Joint Conference of IASPM-Canada and IASPM USA, Yale University, 1988. október 1.)

Simon Géza G. (1990): A magyar jazz 1945-1990. Történeti vázlat. Budapest - Pécs: Jazzbarátok kiskönyvtára 2.

Simon Géza G. (1999): Magyar jazztörténet. Budapest: Magyar Jazzkutatási Társaság.

Somlai Péter (2001): Egyetemesség és heterogenitás (Gondolatok a szociológiáról - Némedi Dénes és Saád József írásai kapcsán). Szociológiai Szemle (2001):1 76-84.

Straw, Will (1991): Systems of Articulation Logics of Change. Communities and Scenes in Popular Music. Cultural Studies 5(3): 368-388. DOI: 10.1080/09502389100490311

Straw, Will (1997): Sizing Up Record Collections: Gender and Connoisseurship in Rock Culture. In Sexing the Groove: Popular Music and Gender. Whiteley, Sheila (szerk.). London és New York, NY: Routledge, 3-16.

Szabó Réka (2014): Kortárs magyar jazz. Egy kulturális szintér feltérképezése a résztvevők tekintetével. (MA-szakdolgozat.) Budapest: BME TK.

Szabó Réka (2017): Kortárs magyar jazz. Egy kulturális színtér feltérképezése a résztvevők tekintetével. In Made in Hungary: Studies in Popular Music. Barna Emília és Tófalvy Tamás (szerk.). New York: Routledge

Szelényi Iván (2016 [2015]): A szociológia hármas válsága. Ford. Éber Márk Áron. Socio.hu Társadalomtudományi Szemle 2016(1): 118-126. Interneten: http://socio.hu/uploads/files/2016_1/szelenyi.pdf (letöltve: 2018. május 1.)

Szemere Anna (2001): Up from the Underground. The Culture of Rock Music in Postsocialist Hungary. University Park: Pennsylvania State University Press. 
Szeverényi Erzsébet (1980): A Dália. Magyar jazz 1962-1964. In Zenetudományi Dolgozatok. Berlász Melinda és Domokos Mária (szerk.). Budapest: MTA Zenetudományi Intézet, 335-344.

Szigeti Péter (2015): Jegyzőkönyv. In Szabados György: Írások III. Boda László és Fülöp Péter (szerk.). Szombathely: B.K.L. Kiadó. 7-26.

Thompson, John B. (1991): Editor's Introduction. In Bourdieu, Pierre (1991) Language and Symbolic Power. Cambridge: Polity Press, 1-32.

Thornton, Sarah (1995): Club Cultures. Music, Media and Subcultural Capital. London: Wesleyan University.

Toynbee, Jason et al. szerk. (2014): Black British Jazz. Routes, Ownership and Performance. Farnham: Ashgate.

Turi Gábor (1983): Azt mondom: Jazz. Budapest: Zenemúkiadó.

Umney, Charles és Kretsos, Lefteris (2013): Creative Labour and Collective Interaction. The Working Lives of Young Jazz Musicians in London. Work Employment \& Society 28(4): 571-588. DOI: 10.1177/0950017013491452

Umney, Charles és Lefteris Kretsos (2015): „That's the Experience”: Passion, Work Precarity, and Life Transitions Among London Jazz Musicians. Work Employment \& Society 42(3): 313-334. DOI: 10.1177/0730888415573634

Van Venrooij, Alex és Schmutz,Vaughn (2010): The Evaluation of Popular Music in the United States, Germany and the Netherlands: A Comparison of the Use of High art and Popular Aesthetic Criteria. Cultural Sociology 4(3): 395-421. DOI: $10.1177 / 1749975510385444$

Varriale, Simone (2014): Cosmopolitan Expertise. Music, Media and Cultural Identities in Italy. PhD-értekezés. Warwick: University of Warwick Department of Sociology

Varriale, Simone (2015): Cultural Production and the Morality of Markets: Popular Music Critics and the Conversion of Economic Power into Symbolic Capital. Poetics (51): $1-16$.

Varriale, Simone (2016): Beyond Distinction: Theorising Cultural Evaluation as a Social Encounter. Cultural Sociology 10(2): 160 -177. DOI: 10.1177/1749975515596447

Veenstra, Gerry (2010): Culture and Class in Canada. Canadian Journal of Sociology/Cahiers canadiens de sociologie 35(1): 83-111.

Vicsek Lilla (2006): Fókuszcsoport. Budapest: Osiris Kiadó

Von Eschen, Penny M. (2004): Satchmo Blows Up the World. Jazz Ambassadors Play the Cold War. Cambridge: Harvard University Press. 
Weinstein, Deena (2000): Heavy Metal. The Music and its Culture. Boston: Da Capo

Wessely Anna (2003): Előszó. In A kultúra szociológiája. Wessely Anna (szerk.). Budapest: Osiris

Wessely Anna (2005): Szocioanalízisben. Buksz 2005 Ösz: 220-230.

Wessely Anna (2012): A mủvészetszociológia - „Kinek nem kell és miért?” Kultúra és közösség 3(1-2): 65-72.

White, Hayden (1973): Metahistory. The Historical Imagination in Nineteenth-Century Europe. Baltimore: Johns Hopkins University Press. [Magyarul részletek: A történelmi cselekményesítés és az igazság problémája. In uő A történelem terhe. Budapest: Osiris, 1997, 251-278.]

Zipernovszky Kornél (2015): Az európai jazz kialakulása és néhány jellegzetes előadója. In A jazz évszázada. Kerekes György, Pallai Péter és Zipernovszky Kornél (szerk.). Budapest: Fidelio, 485-517.

Zipernovszky Kornél (2017): „Ki fog győzni - a jazz vagy a cigány - nehéz megjósolni.” A cigány zenészek megvédik a magyar nemzeti kultúrát. Replika (101-102): 67-87.

Zipernovszky Kornél és Havas Ádám (2017): Lectori salutem! Replika (101-102): 7-12.

\section{Újságcikkek}

Binder Károly (2011): Mélyebbre a gyökerekhez. Népszabadság. 2001. 08. 19. csütörtök Csont András (2008): Egy őszinte öszvér: A magyar blues. Revizor 2008. 08. 08. Interneten: http://revizoronline.com/hu/cikk/674/dresch-mihaly-quartet-argyelus-bmcrecords/?search=1\&txt_ssrc=dresch (letöltve: 2017. február 6.).

Maloschik Róbert (2002): Interjú Oláh Kálmán 32. születésnapja alkalmából. Roma Közösség - Cigány Klub. Interneten: http://romaklub.network.hu/blog/romakozosseg-cigany-klub-hirei/olah-kalman-klasszikus-zongorista-zeneszerzo-kedvenczeneszerzoje-bartok-nyomdokain (letöltve: 2017.02.06.)

Maloschik Róbert (2016): Exkluzív interjú a 60 éves Grencsó Istvánnal. Jazzma.hu 2016.05.09. Interneten: http://www.jazzma.hu/hirek/2016/05/09/exkluziv-interju-a60-eves-grencso-istvannal (letöltve: 2017.01.19.)

Ollion, Etienne (2015). Death is not the end: The rise and rise of Pierre Bourdieu in US sociology. OUPblog. 2015.07.31. Interneten: http://blog.oup.com/2015/07/pierrebourdieu-us-sociology/ (letöltve: 2015.09.26.) 
Pozsár Máté (2016b): Mesterek és tanítványok - Interjú Pozsár Mátéval. Szintenzenesz.reblog.hu. Interneten: http://szintenzenesz.reblog.hu/mesterek-estanitvanyok (letöltve: 2016.12.28.)

Ratliff, Ben (2018): Cecil Taylor, Pianist Who Defied Jazz Orthodoxy, Is Dead at 89. The New York Times. 2018.04.06. Interneten: https://www.nytimes.com/2018/04/06/obituaries/cecil-taylor-dead.html (letöltve: 2018.04.18.)

Ráduly Mihály (2015a): Derengés dupla CS és Adyton jazz tábor: Ráduly Mihály beszélget Grencsó Istvánnal, Benkő Róberttel és Molnár Csabával. Jazzma.hu. 2015. május 18. Interneten: http://www.jazzma.hu/hirek/2015/05/31/derenges-dupla-cd-es-adytonjazz-tabor (letöltve: 2016.12.28.)

Ráduly Mihály (2015b): Hogyan látták Lakatos Pecek Gézát a régi játszótársak. Jazzma.hu. 2015. március 11. Interneten: https://www.jazzma.hu/hirek/2015/03/11/hogyan-lattaklakatos-pecek-gezat-a-regi-jatszotarsak (letöltve: 2018. január 24.)

Ifj. Szakcsi Lakatos Béla (2015): "A jazznek szüksége van a népszerüsítésre" Fidelio. 2015.04.30. Interneten:

https://fidelio.hu/jazzworld/2015/04/30/ifj_szakcsi_lakatos_bela_a_jazznek_szuksege_van_a_nepszerusite sre/ (letöltve: 2018.01.24.)

Szakcsi Lakatos Béla (1981): Hadas Miklós interjúja Szakcsi Lakatos Bélával. Vigilia Október: 703-710.

Szakcsi Lakatos Béla (2013): „Isten az én menedzserem”. Gramofon Ősz: 55-58.

Szakcsi Lakatos Béla (2016a): Beszélgetés Szakcsi Lakatos Bélával zenéről, hitről, halhatatlanságról. Hetek (XX/04)

Szakcsi Lakatos Béla (2016b): „Az előadó müvészetben energia és szellem van” - Interjú Szakcsi Lakatos Bélával. Nullahategy (December 08.)

Truong, Nicolas és Weill Nicolas (2012): A decade after his death, French sociologist Pierre Bourdieu stands tall. The Guardian. 2012. 02. 21. Interneten: http://www.theguardian.com/world/2012/feb/21/pierre-bourdieu-philosophy-mostquoted (letöltve: 2015.09.26.)

Turi Gábor (1999): Különösnek tartom (I’m just kiddin', you know!), hogy nevem mégcsak említésre sem került... Napi Magyarország. 1999. 07. 21. Interneten: http://www.jazzma.hu/hirek/2015/07/13/szabados-gyorgy-es-kora (letöltve: 2016.12.28.) 


\section{Diszkográfia}

Coleman, Ornette (1959): The Shape of Jazz to come. Atlantic Records

Coleman, Ornette (1961): Free Jazz. Atlantic Records

Coltrane, John (1960): Giant Steps. Atlantic Records.

Dés László - Balázs Elemér Quartet - Voces4 Ensemble (2005): Contemporary Gregorian Sony Music.

Egri János (1998): Moods. Infoimpress

Gadó Gábor (2008): Byzantium. BMC Records

Grencsó István (2014): Síkvidék. BMC Records

Parker, Charlie (1990 [1945-54]): Anthropology. Bird: The Complete Charlie Parker on Verve. Verve

Schlippenbach, Alexander von (2005): Monk's Casino. Intakt Records

Szabados György (1964): B-A-C-H élmények. Modern Jazz Anthology 64. Qualiton

\section{Videók}

Csepregi Gyula (2009): JazzBeszéd Egri Jánossal. Miskolc 2009.10.14. Interneten: https://www.youtube.com/watch?v=d1ex_BILUwQ

Ferenczi Gábor (1994): Mi hárman, a család és a jazz. Dokumentumfilm a Trio Midnight zenekarról. Interneten: https://www.youtube.com/watch?v=I0uynSPE1Yg (letöltve: 2017. február 6.). 


\section{A szerző publikációs listája}

\section{Folyóiratcikkek}

Havas Ádám (2018): The Logic of Distinctions in the Hungarian Jazz Field: A Case Study of Hungarian Jazz. Cultural Sociology. (revise and resubmit)

Havas Ádám (2018): A kortárs jazz esztétikai és etnikai konstrukciói: „cigány jazz” és zenei habitus. Szociológiai Szemle (megjelenés alatt)

Havas Ádám (2017): A szabadság dogmatizmusa és a dogmatizmus szabadsága: különbségtételek rendszere a mainstream-free jazz dichotómiában. Replika (101-102): 169-196.

Havas Ádám és Ser Ádám (2017): „Szegény rokonok” - A budapesti jazzszíntér konstrukciója. Replika (101-102): 147-168.

Zipernovszky Kornél és Havas Ádám (2017): Lectori salutem! Replika (101-102): 7-12.

Havas Ádám (2015): A Thália Társaság tagjainak társadalmi beágyazottsága. Színháztudományi Szemle (43). Országos Színháztudományi Múzeum és Intézet. Budapest. Interneten: http://szinhaziintezet.hu/index.php?option=com_content\&view=article\&id=223\&cati $\underline{\mathrm{d}}=$

\section{Recenziók}

Havas Ádám (2018): Book Review: Made in Hungary - Studies in Popular Music. Emília Barna - Tamás Tófalvy (szerk.). Routledge 2017. A Journal of the International Association for Hungarian Studies and Balassi Institute. 2018(02): 283-292. DOI: 10.1556/044.2017.32.1.12

Havas Ádám et al. (2017): Book Review: Theorizing in Social Science: The Context of Discovery by Richard Swedberg. Stanford University Press 2014. Corvinus Journal of Sociology and Social Policy. 8(1): 153-156. DOI: 10.14267/CJSSP.2017.01.12

Havas Ádám (2017): Book review: The Inaudible Music by Bruce Johnson. Foreword by Simon Frith. New South Wales: Currency Press 2000. Interneten: https://static1.squarespace.com/static/58bf64e6c534a5e3ac61401d/t/5931499c197aea 549df14f9a/1496402337710/HavasInaudibleMusicBOOKREVIEW.pdf

Havas Ádám (2011): Recenzió - Génektől a társadalomig: A koragyermekkori fejlődés színterei I. rész. CSAGYI 2011(10). Budapest Interneten: 
http://www.csagyi.hu/hirek/item/239-recenzio-genektol-a-tarsadalomig-akoragyermekkori-fejlodes-szinterei-iresz

Havas Ádám (2011): Recenzió - Génektől a társadalomig: A koragyermekkori fejlődés színterei II. rész. CSAGYI 2011(10). Budapest link: http://www.csagyi.hu/hirek/item/284-recenzio-genektol-a-tarsadalomig-akoragyermekkori-fejlodes-szinterei-iiresz

\section{Konferencia előadások}

Havas Ádám és Ser Ádám (2016): „Szegény rokonok” - A budapesti jazz szintér konstrukciója. In XII. PEME PhD Konferencia. Koncz István és Szova Ilona (szerk.). Budapest: PEME. 111-123. ISBN: 978-963-89915-7-7 Interneten: http://www.peme.hu/userfiles/Konferencia\%20PEME\%20XII.pdf

Havas Ádám (2016): Az irodalmi mezö szerkezete az 1830-as évek egy „pörének” tükrében. In XII. PEME PhD Konferencia (szerk.). Koncz István és Szova Ilona (szerk.). Budapest: PEME. 78-88. ISBN: 978-963-89915-7-7 Interneten: http://www.peme.hu/userfiles/Konferencia\%20PEME\%20XII.pdf

Havas Ádám (2014): Nemzeti Színház koncepciók kultúrpolitikai reprezentációja és diszkurziv konstrukciói. In „Hiteles(ebb) tudományos prezentációk” VIII. Ph.D.konferencia előadásai I. kötet, (szerk.). Koncz István és Szova Ilona (szerk.).Budapest: PEME 27-33. ISBN: 978-963-89915-1-5 Interneten: http://www.peme.hu/userfiles/Interdiszciplin\%C3\%A1ris\%20\%20Pszichol\%C3\%B3gia\%20-\%20Alkalmazott\%20Tanulm\%C3\%A1nyok.pdf

\section{Egyéb}

\section{Kéziratok}

Havas Ádám (2018): Aesthetic and Ethnic Constructions of the Hungarian Jazz Diaspora: 'Gypsy Jazz' and Musical Habitus. Poetics

Hava Ádám (2018): Az irodalmi mező genezise és struktúrája a reformkorban. A születési arisztokrácia és pénz trónfosztása. Korall 
Havas Ádám (2017): Budapest Jazz Club (BJC) programfüzet tudományismertető írások 2017 január-február 17. Internetem: https://www.bjc.hu/pic/programcard/2017january.pdf

Havas Ádám (2017): Budapest Jazz Club (BJC) programfüzet tudományismertető írások 2017 március/április 17. Interneten: https://www.bjc.hu/pic/programcard/2017march.pdf

Havas Ádám (2017): Budapest Jazz Club (BJC) programfüzet tudományismertetô írások 2017 május/június 18. Interneten: https://www.bjc.hu/pic/programcard/2017-may.pdf

Interjú

Havas Ádám (2017): „Bőven lenne dolga az államnak jazz-ügyekben” - interjú Havas Ádámmal, a Replika jazztanulmányi számának társszerkesztőjével a Corvinus Kioksz májusi számában

Interneten:

http://www.lib.unicorvinus.hu/content/corvinuskioszk/jazz-ugyek 


\section{MELLÉKLETEK}

\section{Melléklet}

\section{Interjúvázlat}

I. Általános szekció: „Bemelegít”” kérdések, általános információk a zenészről, zenésznarratíva, bizalmi légkör megteremtése, nemzetközi és magyar zenei referenciák kérdése

1. Hogyan kezdtél el zenélni? (intézmények, tanárok, zenei áramlatok, referenciák)

2. Hány évesen kezdtél el zenélni?

3. Először (jazz) koncertekre jártál, vagy zenélni kezdtél el előbb?

4. Mely bandákat, zenészeket kedveled/kedvelted? Mik voltak a fő zenei hatásik? Miért? Kik a jazz-zenei példaképeid/ meghatározó alakok?

Trombitás:

Szaxofonos:

Gitáros:

Nagybögö:

Zongorista:

Basszusgitár:

Dob:

Pozan:

Egyéb hangszer (perkusszió, vibrafon, orgona stb.):

5. Milyen hangszeren játszol?

6. Szerettél járni konziba/jazztanszakra? Mesélj a (zenei)iskoláról (tanárok, együttesek, hatások stb.)!

6.1. Kikkel zenéltél/barátkoztál a konzi/Zeneakadémia alatt (ha járt)?

7. Vannak tanárok akiket kifejezetten hatással voltak rád? Miért? 
8. Szerinted felkészíti a konzi/Zak/egyéb intézményes oktatás stb. a jazz-zenész karrier?

8.1. Min kellene változtatni? (finanszírozás, oktatás stb.)

9. Hogyan látod a Jazztanszak és Klasszikus tanszak(ok) közti viszonyt?

10. Jelenleg van kereső tevékenységed (haknik, koncertek, színház, szervezés, egyéb ill. ezek kombinációja esetén hol vannak a hangsúlyok, időstruktúra stb.)?

\section{Csoportok, együttesek, közönség, koncertek, jam session}

11. Van jelenleg együttesed/együtteseid? Mióta játszol ezekben a bandákban és kikkel (ha játszik)?

11.1. Hány együttesben voltál eddig?

11.2. Van kedvenced, ha igen, miért?

12. Hogyan írnád le a jazz-koncertek közönségét (szociodemográfiai jellemzők percepciója és ízlése?

12.1. Megkülönböztethetőek különböző csoportok a közönégen belül (nem osztály, stílus, sznobok, jazz-zenészek, más müvészek, értelmiségiek stb.)?

12.2. Elégedett vagy a közönséggel? Miért? (térj ki a helyekre, klubokra!)

13. Jársz jazz koncertekre? Milyen koncertekre? Miért/miért nem? (az egyik indikátora annak, hogy a zenész mennyire látja át a szcénát)

14. Jársz/jártál jam session-re?

\subsection{Miért?}

14.2 Milyen a hangulatuk?

14.2. Mesélj sztorikat ha vannak, ami alátámasztják a mondandód!

14.4 Demokratikusnak tartod? Mindenki játszhat? Vannak csoportok/zenészek akik kisajátítják a sessiönöket? Miben nyilvánul ez meg?

14.5. Van köze a jam session-nek egyfajta hierachia létrehozásában, vagy puszta szórakozásról szól?

14.6 Kikkel játszol/játszottál és miért? Kikkel nem? 


\section{Szimbolikus és gazdasági rétegződéssel kapcsolatos kérdések: megkülönböztetések, oppozíciók, diszpozíciók, csoportok közti viszonyok stb.}

15. Van-e kapcsolat megbecsültség és hangszer közt? Mik a népszerü hangszerek, miért?

16. Szerinted rétegzene/szubkultúra a jazz (vagy nem foglalkoztat a kérdés)?

17. Hogyan definiálnád a jazzt (technikai és esztétikai jellemzők)?

17.1. Egyetértesz azzal a definícióval, hogy a jazzt a (1) szvinges ritmus, (2) sztenderdek ismerete és (3) jazzes játékmód "frazír" határozza meg? Miért?

17.2. Mitől less valaki “jó” jazz-zenész?

18. Szerinted vannak különbségek jazz-zenészek közt származás, generáció társadalmi háttér, nem alapján (egyes szempontok szt. mesélj történeteket)?

18.1. Generáció, osztály stb.:

18.2. Etnikai/vallási csoportok:

18.3. Nem alapján (nők milyen hangszeren leginkább, miért van kevés női hangszeres?)

18.4. Fontos a Lisztre/konziba járni, hogy elismerjenek? Miben látod a szerepét?

18.5. Autodidakta VS “iskolás” zenész

19. Milyen stílusokat, trendeket különböztetsz meg a Magyar jazzen belül? Mndj neveket, együtteseket stb. (itt is rákérdezek konkrét elöadókra, ha kell provokativ kérdéseket is felteszek korábbi interjúk alapján névtelenül, hogy az izlését/véleményét megtudjam)

20. Ki sikeres? Milyen stílust játszanak a sikeres zenészek, miért?

21. Mit szeret a közönség?

22. Van a jazzen belül egy elit réteg akit mindenki tisztel? Kik ők és miért?

23. Van olyan kör, közeg, csoport, zenész akit "nem szeretnek", akitöl távolságot tartanak/nm szeretnek játszani?

24. Mit gondolsz, milyen stratégiát követve válhatsz elismert jazz-zenésszé (oktatás, barátok, kapcsolatok, pénz, szerencse, kapcsolatok, család, tehetség stb.)?

24.1. Milyen arányban élnek meg itthon a zenéből?

24.2. Kik és milyen zenét játszanak?

24.3. Te megélsz a zenélésből? 
25. Fontosnak tartod más társmüvészetek ismeretét? (arra kérdezek ré szerintük mennyire müveltek a jazz-zenészek és ennek van-e valami jelentösége)

26. Tapasztalsz feszültségeket a zenélés/koncertek/haknik színvonala és saját elvárásaid között? (itt a piac és a “tiszta müvészeti” tétek közti kapcsolat érdekel)

26.1. Kell kompromisszumokat hoznod? Miket?

27. Hogyan írnád le a saját zenédet amit játszol, illetve amit legszívesebben játszanál?

28. Mennyire látod zártnak, zárkózottnak a közeget?

28.1. Vannak klikkek? Kik között? Mi benne a saját szereped?

29. Vannak stílusok melyeket kifejezetten nem szeretsz? Miért (itt is külön rákérdezek elöadókra, azért nem a kérdés elejére tettem mert akkor még kevésbé alakul ki a bizalom a kérdezö és az interjúalany közt)

30. Mi népszerü manapság?

31. Vannak átjárások a csoportok, stílusok és/vagy "klikkek" közt?(milyen együttmüködések vannak egyéb müvészekkel vagy müvészeti ágakkal és hogy mi a jelentöségük ha van)

32. Vannak kifejezetten konfliktusok zenészek közt? Mesélj történetet ha van!

33. Hogyan látod a magyar jazz jövőjét? Min kéne változtatni? 
2. Melléklet: Fejes László (1965) „Esküvő”. Az 1965-ös Worldpress sajtófotó pályázat győztes képe. A kép nem lehetett az azonos címü '75-ös Szabados album borítója, a 2002-es kiadáson már a Fejes-kép szerepel (3. melléklet)

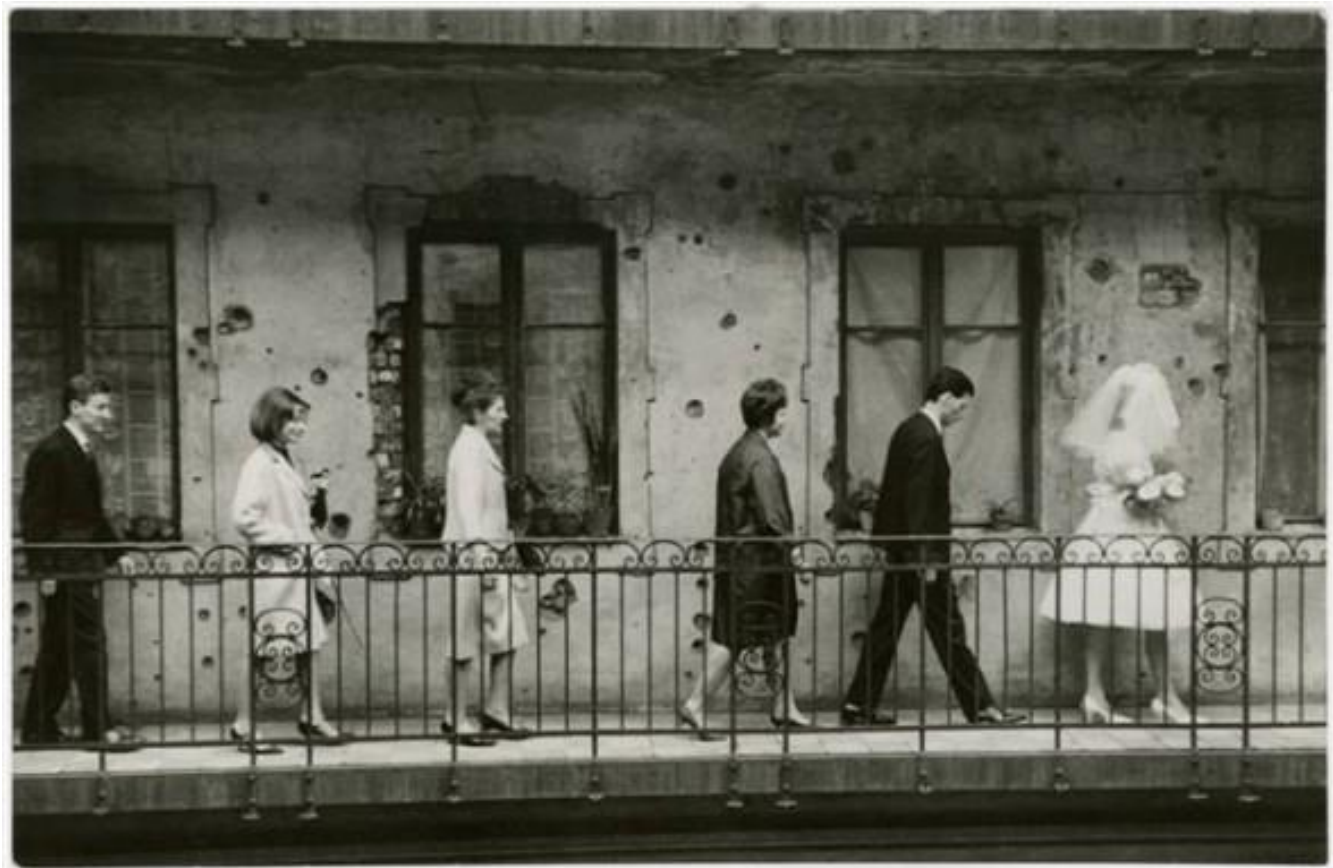

3. Melléklet: Szabados György „Esküvő” c. lemeze Fejes képével a borítón

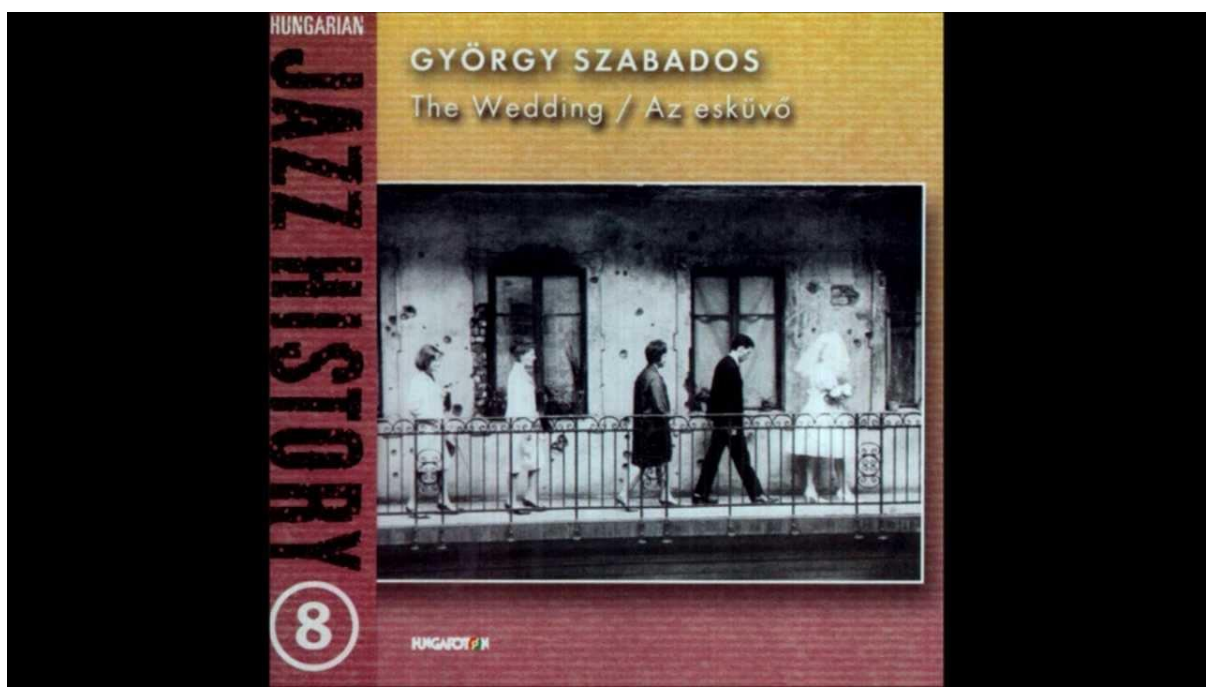


4. Melléklet: Egri János „Moods” c. lemezének belső borítója, mely jazz-zenész fiát, ifj. Egri Jánost és lányát ábrázolja

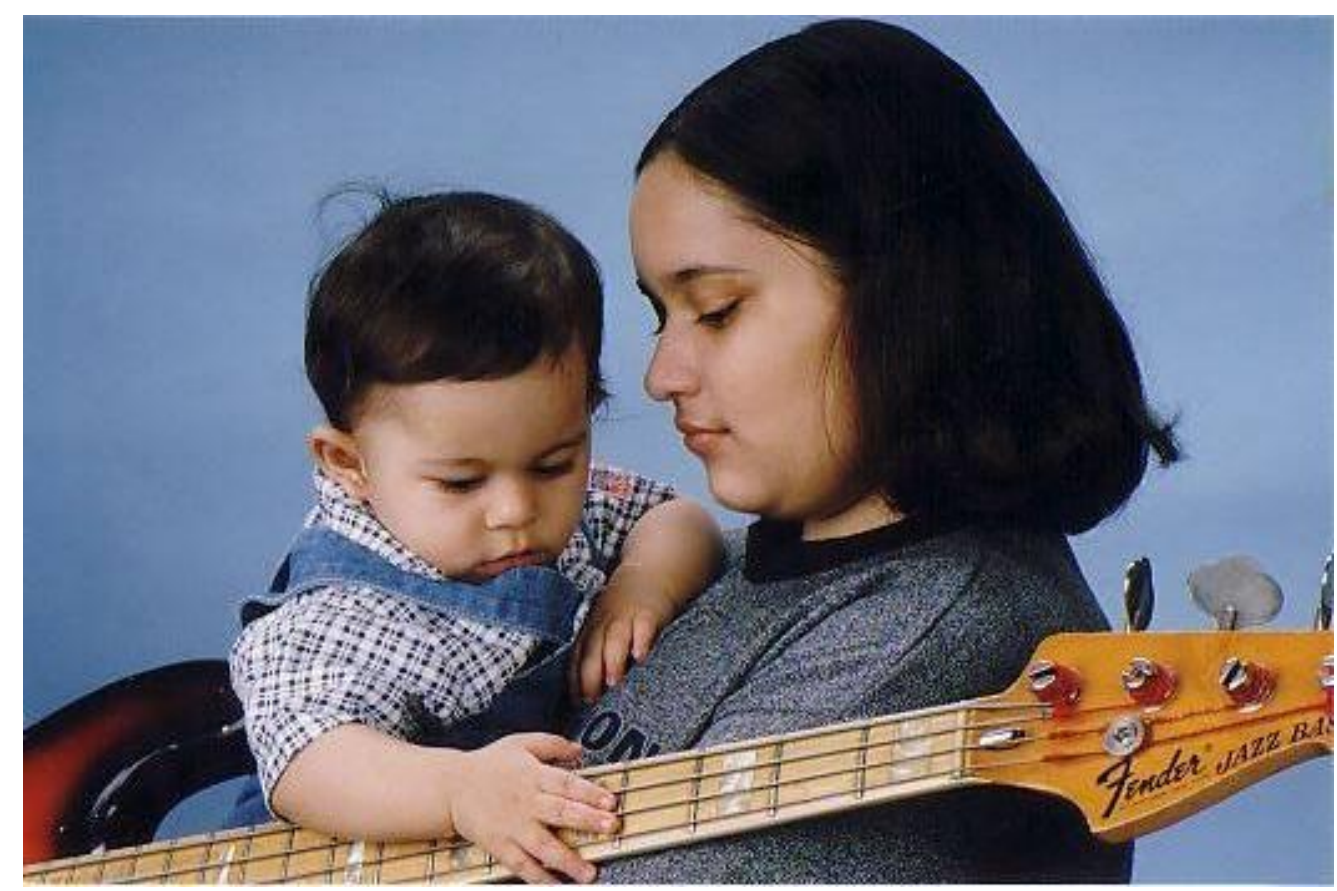

